ANL-CEN-RSD-80-3
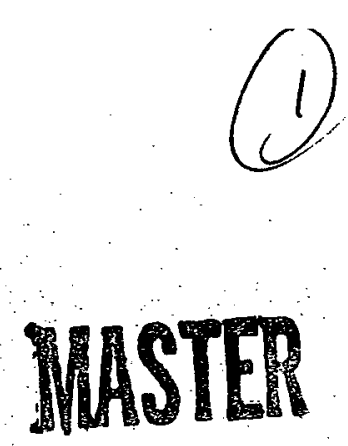

ANL-CEN-RSD-80-3
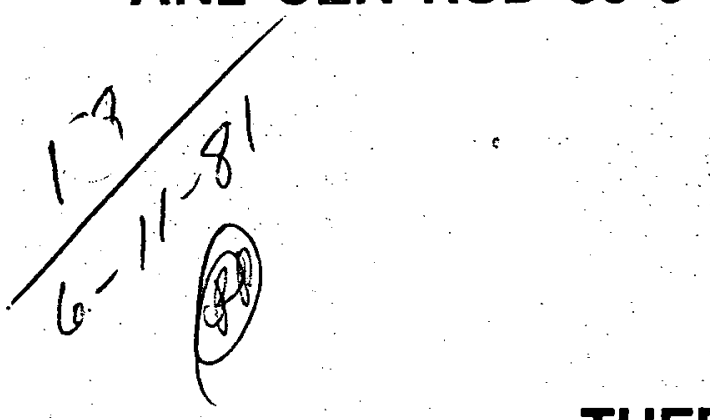

\title{
THERMODYNAMIC PROPERTIES OF URANIUM DIOXIDE
}

\author{
by \\ J. K. Fink; M. G. Chasanov, \\ and $L$. Leibowitz
}

- ARGONNE NATIONAL LABORATORY, ARGONNE, ILLINOIS Prepared for the U. S. DEPARTMENT OF ENERGY under Contract W-31-109-Eng-38 


\section{DISCLAIMER}

This report was prepared as an account of work sponsored by an agency of the United States Government. Neither the United States Government nor any agency Thereof, nor any of their employees, makes any warranty, express or implied, or assumes any legal liability or responsibility for the accuracy, completeness, or usefulness of any information, apparatus, product, or process disclosed, or represents that its use would not infringe privately owned rights. Reference herein to any specific commercial product, process, or service by trade name, trademark, manufacturer, or otherwise does not necessarily constitute or imply its endorsement, recommendation, or favoring by the United States Government or any agency thereof. The views and opinions of authors expressed herein do not necessarily state or reflect those of the United States Government or any agency thereof. 


\section{DISCLAIMER}

Portions of this document may be illegible in electronic image products. Images are produced from the best available original document. 
The facilities of Argonne National Laboratory are owned by the United States Government. Under the terms of a contract (W-31-109-Eng-38) among the U. S. Department of Energy, Argonne Universities Association and The University of Chicago, the University employs the staff and operates the Laboratory in accordance with policies and programs formulated, approved and reviewed by the Association.

\section{MEMBERS OF ARGONNE UNIVERSITIES ASSOCIATION}

$\begin{array}{ll}\text { The University of Arizona } & \text { The University of Kansas } \\ \text { Carnegie-Mellon University } & \text { Kansas State University } \\ \text { Case Western Reserve University } & \text { Loyola University of Chicago } \\ \text { The University of Chicago } & \text { Marquette University } \\ \text { University of Cincinnati } & \text { The University of Michigan } \\ \text { Illinois Institute of Technology } & \text { Michigan State University } \\ \text { University of Illinois } & \text { University of Minnesota } \\ \text { Indiana University } & \text { University of Missouri } \\ \text { The University of Iowa } & \text { Northwestern University } \\ \text { lowa State University } & \text { University of Notre Dame }\end{array}$

The Ohio State University

Ohio University

The Pennsylvania State University

Purdue University

Saint Louis University

Southern Illinois University

The University of Texas at Austin

Washington University

Wayne State University

The University of Wisconsin-Madison

\section{NOTICE}

This report was prepared as an account of work sponsored by an agency of the United States Government. Neither the United States Government or any agency thereof, nor any of their employees, make any warranty, express or implied, or assume any legal liability or responsibility for the accuracy, completeness, or usefulness of any information, apparatus, product, or process disclosed, or represent that its use would not infringe privately owned rights. Reference herein to any specific commercial product, process, or service by trade name, mark, manufacturer, or otherwise, does not necessarily constitute or imply its endorsement, recommendation, or favoring by the United States Government or any agency thereof. The views and opinions of authors expressed herein do not necessarily state or reflect those of the United States Government or any agency thereof.

Printed in the United States of America

Available from

National Technical Information Service

U. S. Department of Commerce

5285 Port Royal Road

Springfield; VA 22161

NTIS price codes

Printed copy: A09

Microfiche copy: A01 
Distribution Category:

General, Miscellaneous, and Progress Reports (Nuclear) (UC-2)

ANL-CEN-RSD-80 - 3

ARGONNE NATIONAL LABORATORY

9700 South Cass Avenue

Argonne, Illinois 60439

THERMODYNAMIC PROPERTIES OF URANIUM DIOXIDE

by

J. K. Fink, M. G. Chasanov, and L. Leibowitz

Chemical Engineering Division

April 1981

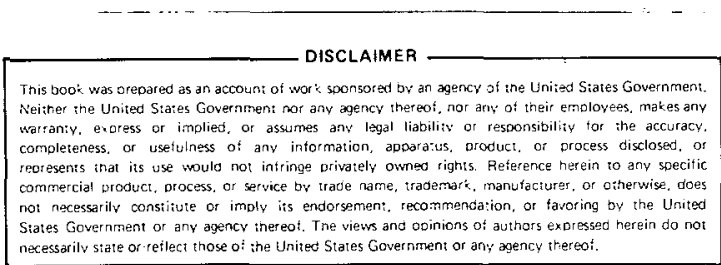

This document is

PUBLICLY RELEASABLE 


\section{PREFACE}

\section{Thermodynamic Properties of Uranium Dioxide}

In order to provide reliable and consistent data on the thermophysical properties of reactor materials for reactor safety studies, we have prepared this revision of the thermodynamic properties of the uranium dioxide portion of the fuel property section of the report "Properties for LMFBR Safety Analysis." Since the original report was issued in 1976, there has been international agreement on a vapor pressure equation for the total pressure over $\mathrm{UO}_{2}$, new methods have been suggested for the calculation of enthalpy and heat capacity, ${ }^{1,2}$ and a phase change at $2670 \mathrm{~K}$ has been proposed. ${ }^{3}$ In this report, an electronic term is used in place of the Frenkel defect term in the enthalpy and heat capacity equations and the phase transition is accepted. The sections on density and thermal expansion have been completely revised to contain exact relations between the various thermal expansion coefficients and the density. In addition, new experimental measurements of surface tension have been included. The use of mechanical properties to calculate compressibility has made it possible to include calculated estimates of values of properties not included in the original report. The present report comprises part of the $\mathrm{UO}_{2}$ portion of section $\mathrm{A}$ of the planned complete revision of "Properties for LMFBR Safety Analysis."

As much as possible, we have attempted to have each section independent of the others. Although this has entailed considerable repetition, we believe this will be helpful to users of this handbook. A user not needing great detail regarding the basis for the calculations will be able to read only the section of interest. Tables giving estimated standard deviations ( $1 \sigma$ ) have been included. These have been given as percents and it should 
be understood that a value of $100 \%$ means a standard deviation of a factor of two. We have also included a set of tables of closely spaced values. Comments from users of this material regarding errors, format, and utility would be appreciated.

J. K. Fink

L. Leibowitz 


\section{REFERENCES}

1. M. H. Rand, K. J. Ackermann, F. Gronvold, F. L. Oetting, and A. Pattoret Rev. Int. Hautes Temp. et Refract., 15, 355 (1978).

2. R. A. Young, J. Nucl. Mat., 87, 283 (1979).

3. M. A. Bredig, Coll. Int. sur l'etudes des transformations crystalline a haute temperature, Odeillo, p. 183 (1971). 
Acknowledgments

The authors are indebted to R. L. Gibby and O. D. Slagle (Hanford Engineering Development Laboratory) for their contributions on density and thermal expansion. We are also appreciative of the valuable comments of M. G. Adamson (General Electric Corp.), J. Belle (Westinghouse Electric Corp.), and R. A. Young (University of Arizona). We also thank Peggy McBride and Stefanie Chapman for their assistance in the preparation and typing of this report. 
SECTION A: FUEL

1. $\mathrm{UO}_{2}$ PROPERTIES

\subsection{SUMMARY}

1.1 THERMODYNAMIC - Saturated

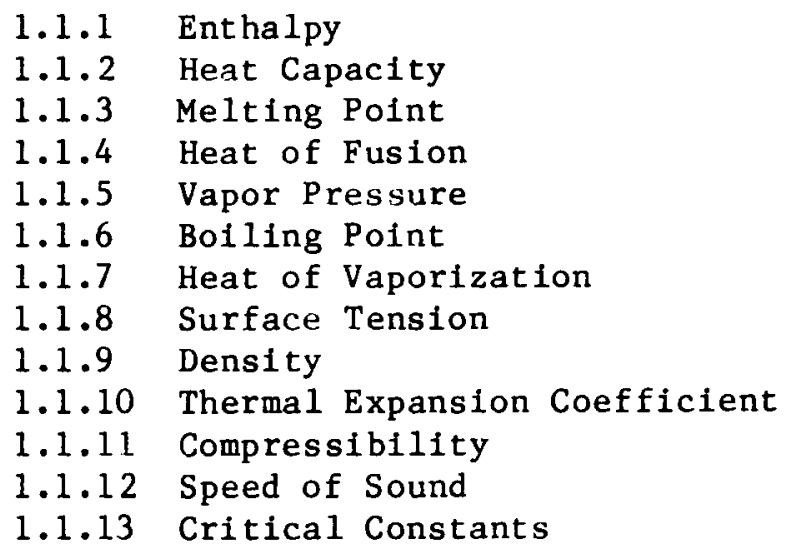

APPENDIX A: TABULATED THERMODYNAMIC PROPERTIES IN SI UNITS

APPENDIX B: TABULATED THERMODYNAMIC PROPERTIES IN CGS UNITS 
SUMMARY OF THERMODYNAMIC PROPERTIES

\begin{tabular}{|c|c|c|c|c|c|c|}
\hline \multirow[t]{2}{*}{ Property } & \multicolumn{4}{|c|}{ Temperature, $\mathrm{K}$} & \multirow[b]{2}{*}{5000} & \multirow[b]{2}{*}{6000} \\
\hline & 1000 & 2000 & $3120(\mathrm{~m} \cdot \mathrm{p} \cdot)$ & 4000 & & \\
\hline Entha1py, $H(T)-H(298), k J \cdot \mathrm{mol}^{-1}$ & 54.59 & 144.4 & $\begin{array}{l}302.8(\mathrm{~s}) \\
377.7(\mathrm{l})\end{array}$ & $(493)$ & $(624)$ & $(755)$ \\
\hline Heat Capacity, $\mathrm{C}_{\mathrm{P}}, \mathrm{J} \cdot \mathrm{mo}^{-1} \cdot \mathrm{K}^{-1}$ & 84.21 & 98.68 & $\begin{array}{l}167(s) \\
131(\ell)\end{array}$ & $(131)$ & $(131)$ & $(131)$ \\
\hline Vapor Pressure $\mathrm{P}, \mathrm{MPa}$ & $3.09 \times 10^{-24}$ & $1.35 \times 10^{-8}$ & $5.59 \times 10^{-3}$ & 0.40 & 6.3 & (33) \\
\hline Density, $\rho, \mathrm{kg} \cdot \mathrm{m}^{-3}$ & 10763 & 10326 & $\begin{array}{l}9651(\mathrm{~s}) \\
8739(\ell)\end{array}$ & $(7948)$ & $(7049)$ & $(6151)$ \\
\hline $\begin{array}{l}\text { Instantaneous Volunetric expansion } \\
\text { coefficient, } \alpha_{\mathrm{P}} \times 10^{5}, \mathrm{~K}^{-1}\end{array}$ & 3.29 & 5.01 & $\begin{array}{cc}7.06 & (s) \\
10.5 & (\ell)\end{array}$ & $(10.2)$ & $(9.9)$ & $(9.5)$ \\
\hline $\begin{array}{l}\text { Adiabatic Compressibility, } \\
{ }^{B} \mathrm{~S} \times 10^{5}, \mathrm{MPa}^{-1}\end{array}$ & 0.533 & - & $3.31(l)$ & $(6.16)$ & $(11.8)$ & $(24.6)$ \\
\hline Surface Tension, $\mathrm{N} \cdot \mathrm{m}^{-1}$ & - & - & $.494(\ell)$ & - & - & - \\
\hline
\end{tabular}

\section{(s) indicates solid \\ (l) indicates liquid}

Values in parenthesis were obtained by extrapolation beyond the range of available data.

Melting Point, $\mathrm{T}_{\mathrm{n}}=3120 \mathrm{~K}$

Heat of Fusion, $\Delta \mathrm{H}_{\mathrm{f}}=75.7 \mathrm{~kJ} \cdot \mathrm{nol}^{-1}$

Boiling Point, $\mathrm{T}_{\mathrm{B}}=3660 \mathrm{~K}$

Heat of Vaporization, $\Delta \mathrm{H}_{\mathrm{g}}=497 \mathrm{~kJ} \cdot \mathrm{nol}^{-1}$ at $\mathrm{T}_{\mathrm{B}}$ 
A 1.1 .1 .1

$12 / 80$

URANIUM DIOXIDE

$\mathrm{H}$

Solid Enthalpy $\left(\mathrm{kJ} \cdot \mathrm{mol}^{-1}\right)$

\begin{tabular}{|c|c|}
\hline $\mathrm{T}, \mathrm{K}$ & $\mathrm{H}(\mathrm{T})-\mathrm{H}(298.15)$ \\
\hline 298.15 & 0.0 \\
\hline 300 & 0.1178 \\
\hline 400 & 6.914 \\
\hline 500 & 14.27 \\
\hline 600 & 21.96 \\
\hline 700 & 29.88 \\
\hline 800 & 37.98 \\
\hline 900 & 46.22 \\
\hline 1000 & 54.59 \\
\hline 1100 & 63.06 \\
\hline 1200 & 71.64 \\
\hline 1300 & 80.32 \\
\hline 1400 & 89.10 \\
\hline 1500 & 97.96 \\
\hline 1600 & 106.9 \\
\hline 1700 & 116.0 \\
\hline 1800 & 125.3 \\
\hline 1900 & 134.7 \\
\hline 2000 & 144.4 \\
\hline 2100 & 154.5 \\
\hline 2200 & 165.1 \\
\hline 2300 & 176.3 \\
\hline 2400 & 188.3 \\
\hline 2500 & 201.5 \\
\hline 2600 & 216.1 \\
\hline $2670(\alpha)$ & 227.3 \\
\hline $2670(\beta)$ & 227.6 \\
\hline 2700 & 232.7 \\
\hline 2800 & 249.4 \\
\hline 2900 & 266.1 \\
\hline 3000 & 282.8 \\
\hline 3100 & 299.5 \\
\hline 3120 (s) & 302.8 \\
\hline
\end{tabular}


A 1.1 .1 .2

$12 / 80$

URANIUM DIOXIDE

Liquid Enthalpy $\left(\mathrm{kJ} \cdot \mathrm{mo1}^{-1}\right)$

\begin{tabular}{|c|c|}
\hline $\mathrm{T}, \mathrm{K}$ & $\mathrm{H}(\mathrm{T})-\mathrm{H}(298.15)$ \\
\hline 3120 & 377.7 \\
\hline 3200 & 388.1 \\
\hline 3300 & 401.2 \\
\hline 3400 & 414.3 \\
\hline 3500 & 427.4 \\
\hline 3600 & $(440.5)^{*}$ \\
\hline 3700 & $(453.6)$ \\
\hline 3800 & $(466.7)$ \\
\hline 3900 & $(479.8)$ \\
\hline 4000 & $(492.9)$ \\
\hline 4100 & $(506.0)$ \\
\hline 4200 & $(519.1)$ \\
\hline 4300 & $(532.2)$ \\
\hline 4400 & $(545.3)$ \\
\hline 4500 & $(558.4)$ \\
\hline 4600 & $(571.5)$ \\
\hline 4700 & $(584.6)$ \\
\hline 4800 & $(597.6)$ \\
\hline 4900 & $(610.7)$ \\
\hline 5000 & $(623.8)$ \\
\hline 5100 & $(636.9)$ \\
\hline 5200 & $(650.0)$ \\
\hline 5300 & $(663.1)$ \\
\hline 5400 & $(676.2)$ \\
\hline 5500 & $(689.3)$ \\
\hline 5600 & $(702.4)$ \\
\hline 5700 & $(715.5)$ \\
\hline 5800 & $(728.6)$ \\
\hline 5900 & $(741.7)$ \\
\hline 6000 & $(754.8)$ \\
\hline
\end{tabular}

* Parentheses indicate extrapolated beyond range of data. 
A 1.1 .1 .3

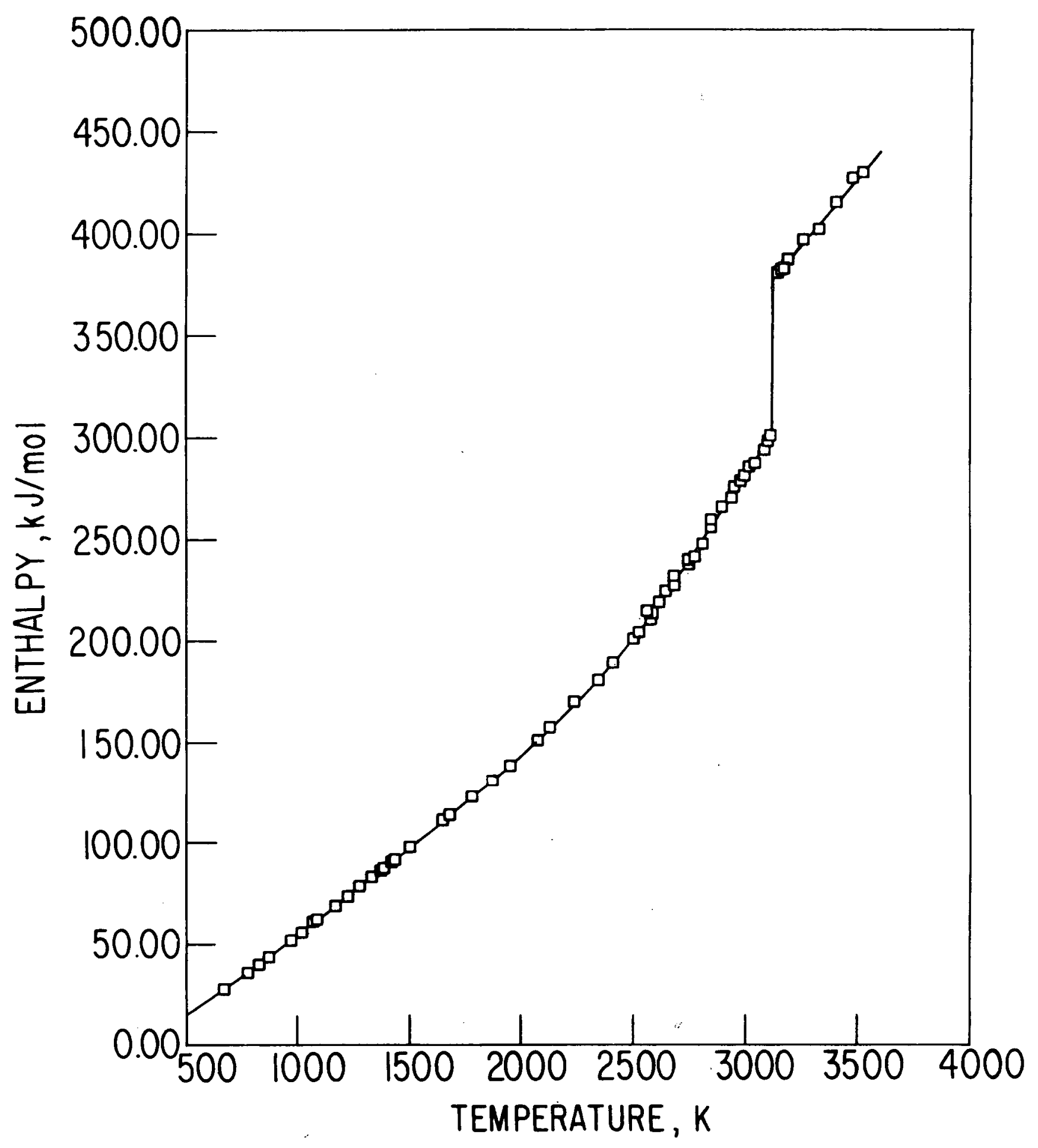

A comparison of the recommended enthalpy functions for $\mathrm{UO}_{2}$ with experimental enthalpy data. 


\section{Enthalpy}

Temperature Range

$$
\mathrm{T}, \mathrm{K}
$$

$298.15-2670($ solid $)$

$(78.212)(516.11)[\exp (516.11 / \mathrm{T})-1]^{-1}$

$-[\exp (516.11 / 298.15)-1]^{-1}$

$+3.8616 \times 10^{-3}\left(\mathrm{~T}^{2}-88893\right)$

$+\left(3.3993 \times 10^{8}\right)\left(8.6144 \times 10^{-5}\right)(\mathrm{T}-298.15)$

$\exp \quad-1.8815 /\left(8.6144 \times 10^{-5} \mathrm{~T}\right)$

$2670-3120$ (solid)

$167.04 \mathrm{~T}-218342$

1

$3120-3500$ (1iquid)

$3500-5000$

$130.95 \mathrm{~T}-30911$

$5000-6000$ 


\section{A 1.1 .1 .5}

\section{Enthalpy}

Experimental data ${ }^{1-13}$ from 298 to $3120 \mathrm{~K}$ for the enthalpy and heat capacity of solid $\mathrm{UO}_{2}$ have been reported in the literature. To correlate these data, a modified Einstein relationship was used by Kerrisk and Clifton ${ }^{14}$ for the solid, while a simple linear equation proved satisfactory for the liquid region data. Rand et al. ${ }^{15}$ have further analyzed the enthalpy and heat capacity data for the solid, and concluded that the Bredig $^{16}$ proposal of a diffuse phase transition in $\mathrm{UO}_{2}$ at $2670 \mathrm{~K}$ is reasonably supported. They then employed the Kerrisk and Clifton-type equation to fit the enthalpy data ${ }^{1,2,4-7,12,13}$ below $2670 \mathrm{~K}$ and a linear equation to fit the data for solid UO ${ }_{2}$ above that temperature.

The Kerrisk-Clifton equation used to fit the enthalpy data consists of three terms.

$$
\begin{aligned}
H(T)-H(298)= & C_{1} \theta\left[\left(e^{\theta / T}-1\right)^{-1}-\left(e^{\theta / 298}-1\right)^{-1}\right] \\
& +C_{2}\left[T^{2}-(298)^{2}\right] \\
& +C_{3} e^{-E_{d} / R T}
\end{aligned}
$$

The first term which dominates at low temperature is due to the phonon contribution. The second term is a contribution due to volumetric thermal expansion. The third term contains the anomalous contribution not included in the first two. The form chosen for this last term in the Kerrisk-Clifton treatment was that due to Frenkel defects. Here $E_{d} / R$ is the activation temperature for formation of an anion Frenkel defect. 
Young, ${ }^{17}$ Harding, et al. ${ }^{18}$ and MacInnes and Catlow ${ }^{19}$ have pointed out that it is more appropriate to attribute this anomalous contribution to electron effects. Young suggests that the third term should be of the form:

$$
C_{3} k T e^{-E_{a} / k T}
$$

where $k$ is the Boltzmann constant and $E_{a}$ is the energy gap between conduction and valence bands.

The enthalpy and heat capacity data for $\mathrm{UO}_{2}{ }^{1-13}$ have been reexamined by us. Comparisons were made with fits using (1) a Kerrisk-clifton equation over the entire temperature range, (2) a Kerrisk-Clifton formulation for the first two terms and an electronic term for the anomalous contribution, (3) the Rand formulation using two equations, and (4) the Rand formulation with an electronic term. We found that the data were best fit by (4) with a transition temperature of $2670 \mathrm{~K}$ as proposed by Rand.

The recommended equations for enthalpy are:

for $298 \leq \mathrm{T} \leq 2670 \mathrm{~K}$

$$
\begin{aligned}
H(T)-H(298.15)= & C_{1} \theta\left[\left(e^{\theta / T}-1\right)^{-1}-\left(e^{\theta / T^{*}}-1\right)^{-1}\right] \\
& +C_{2}\left[T^{2}-\left(T^{*}\right)^{2}\right] \\
& +C_{3} k\left(T-T^{*}\right) e^{-E_{a} / k T}
\end{aligned}
$$


A 1.1 .1 .7

$12 / 80$

URANIUM DIOXIDE

H

$$
\text { where } \begin{aligned}
\mathrm{T}^{*} & =298.15 \mathrm{~K}, \\
\mathrm{C}_{1} & =78.212 \mathrm{~J} \cdot \mathrm{mol}-1 \cdot \mathrm{K}-1 \\
\mathrm{C}_{2} & =3.8616 \times 10^{-3} \mathrm{~J} \cdot \mathrm{mol}^{-1} \cdot \mathrm{K}^{-2}, \\
\mathrm{C}_{3} & =3.3993 \mathrm{x} 10^{8} \mathrm{~J} \cdot \mathrm{mol}^{-1} \cdot \mathrm{eV}^{-1}, \\
E_{a} & =1.8815 \mathrm{eV}, \\
\theta & =516.11 \mathrm{~K}, \\
\text { and } \mathrm{k} & =8.6144 \mathrm{x} 10^{-5} \mathrm{eV} / \mathrm{K} \text { is the Boltzmann constant; }
\end{aligned}
$$

for $2670 \leq T \leq 3120$,

$$
H(T)-H(298.15)=167.04 T-218342 .
$$

In Eqs. (3-4), $\mathrm{H}$ is in $\mathrm{J} / \mathrm{mol}$ and $\mathrm{T}$ is in kelvins. The factor $(\mathrm{T}-298.15)$ is used in the third term of Eq. (3) to satisfy the constraint that $H(T)-H(298.15)$ is zero at $T=298.15 \mathrm{~K}$. The condition $\frac{\mathrm{dH}}{\mathrm{dT}}(\mathrm{T}=298.15)=$ $15.20 \frac{\mathrm{ca} 1}{\mathrm{~mol} \cdot \mathrm{K}}$ was used to constrain the five parameters $\mathrm{C}_{1}, \mathrm{c}_{2}, \mathrm{C}_{3}, \mathrm{E}_{\mathrm{a}}$, and $\theta$. Thus, while five parameters are given, only four of them are independent.

In examining the experimental data, we have chosen not to include some measurements in the fit. The data of Affortit 8,9 seem to be clearly at variance with those of several other workers and has not been included. In the region from about room temperature to $1500 \mathrm{~K}$ the measurements of Moore and Kelley ${ }^{3}$ and those of Ogard and Leary ${ }^{2}$ do not agree well with those of Fredrickson and Chasanov. ${ }^{7}$ Because of the good agreement of Fredrickson and Chasanov ${ }^{7}$ with Hein and Flage $11 a^{6}$ who in turn agree well at high temperatures with Leibowitz et a1., ${ }^{1}$ we have 
selected the data of Fredrickson and Chasanov $^{7}$ for use in the moderate temperature range. The recommended set of values would not change very much if we had included all the enthalpy data.

Not only does this final equation give a better fit to the data but it also eliminates discontinuities that existed using the two equations proposed by Rand. Using Rand's equations, the change in enthalpy at the $2670 \mathrm{~K}$ phase transition is $1.82 \mathrm{~kJ} / \mathrm{mol}(0.8 \%)$ and the change in the derivative of enthalpy (heat capacity) is $16.88 \mathrm{~J} / \mathrm{mol}$ or a change of $10 \%$. No discontinuity is seen experimentally at $2670 \mathrm{~K}$ for other properties such as thermal diffusivity, density, or thermal conductivity. Consequently, the use of enthalpy and heat capacity equations containing a discontinuity creates consistency problems in the calculation of other thermodynamic and transport properties. Our recommended equations give a to.3 $\mathrm{kJ} / \mathrm{mol}(0.13 \%)$ change in enthalpy at $2670 \mathrm{~K}$ and a $+0.6 \mathrm{~J} / \mathrm{mol} \cdot \mathrm{K}$ or $0.36 \%$ change in its temperature derivative at $2670 \mathrm{~K}$. These differences are within the relative standard deviation of the fit $(0.61 \%)$.

For the liquid range of $\mathrm{UO}_{2}$, Rand et al. ${ }^{15}$ fitted the data from 3120 to $3531 \mathrm{~K}$ to a linear equation, which we have accepted, and obtained: for $3120 \mathrm{~K} \leq \mathrm{T} \leq 3530 \mathrm{~K}$,

$$
H(T)-H(298.15)=130.95 \mathrm{~T}-30911
$$

where $\mathrm{H}$ is in $\mathrm{J} / \mathrm{mol}$ and $\mathrm{T}$ is in kelvins.

The enthalpy of melting, determined from these equations for solid and liquid $\mathrm{UO}_{2}$ at the melting point $(3120 \mathrm{~K})$, is $74830 \mathrm{~J} / \mathrm{mol}$. Above the maximum experimental temperature $(3531 \mathrm{~K})$, the enthalpy of $\mathrm{UO}_{2}$ was calculated assuming a constant heat capacity of $130.95 \mathrm{~J} / \mathrm{mol} \cdot \mathrm{K}$. 
A 1.1 .1 .10

$12 / 80$

URANIUM DIOXIDE

\section{$\underline{\text { References }}$}

1. L. Leibowitz, L. W. Mishler, and M. G. Chasanov, J. Nucl. Mat. 29, 356 (1969).

2. A. E. Ogard and J. A. Leary, "Thermodynamics of Nuclear Materials-1967," IAEA, Vienna, p. 651 (1969).

3. G. E. Moore and K. K. Kelley, J. Am. Chem. Soc. 69, 2105 (1947).

4. R. A. Hein, L. H. Sjodahl, and R. Szwarc, J. Nucl. Mat. 25, 99 (1968).

5. J. B. Conway and R. A. Hein, J. Nucl. Mat. 15, 149 (1965).

6. R. A. Hein and P. N. Flagella, "Enthalpy Measurements of $\mathrm{UO}_{2}$ and Tungsten to $3260^{\circ} \mathrm{K}$," General Electric report GEMP-578, February 16 (1980).

7. D. R. Fredrickson and M. G. Chasanov, J. Chem. Thermodynamics. 2, 263 (1970).

8. C. Affortit and J. Marcon, Rev. Int. Hautes Temp. et Refract. $\underline{7}, 236$ (1970).

9. C. Affortit, High Temperatures - High Pressures $\underline{1}, 27-33$ (1969).

10. T. K. Enge1, J. Nuc1. Mat. 31, 211 (1969).

11. M. M. Popov, G. L. Gal'chenko, and M. D. Seniv, Zh. Neorg, Khim, 3 , 1734-1737 (1958), Trans. J. Inorganic Chem., USSR, 18-22 (1958).

12. F. Grфnvold, N. J. Kveseth, A. Sveen, and J. Tichý, J. Chem. Thermodynamics $\underline{2}, 665-679$ (1970).

13. J. J. Hunzicker and E. F. Westrum, J. Chem. Thermodynamics $\underline{3}, 61$ (1971)

14. J. F. Kerrisk and D. G. Clifton, Nuc1. Tech. 16, 531 (1972).

15. M. H. Rand, R. J. Ackermann, F. Grønvold, F. L. Oetting, and A. Pattoret, Rev. Int. Hautes Temp. et Refract. 15, 355 (1978). 
The liquid enthalpy data of Hein et al. ${ }^{6}$ and of Leibowitz et al. ${ }^{20}$ are fit with a relative standard deviation of $0.41 \%$ by Eq. (5). Interestingly, the enthalpies obtained using Eq. (5) from $3500 \mathrm{~K}$ to $6000 \mathrm{~K}$ are within $2 \%$ of the values predicted by Booth ${ }^{21}$ in 1969 using Hirshfelder's generalized equation-of-state. 22

In the temperature range 298 to $2670 \mathrm{~K}$, the estimated error $(1 \sigma)$ is $\pm 0.6 \%$ and is based on a least squares analysis. From $2670 \mathrm{~K}$ to the melting point, the error in the fit is $\pm 1 \%$. Above the melting point, the estimated error is temperature dependent ranging from $\pm 1 \%$ below $3500 \mathrm{~K}$ to $20 \%$ above $5000 \mathrm{~K}$. 
A 1.1 .1 .11

$12 / 80$

URANIUM DIOXIDE

References (Cont'd)

16. M. A. Bredig, Coll. Int. sur l'etudes des transformations crystalline a haute temperature, Odeillo, p. 183 (1971).

17. R. A. Young, J. Nucl. Mat. 87, 283-296 (1979).

18. J. H. Harding, P. Masri, and A. M. Stoneham, J. Nucl. Mat. 92, 73 (1980).

19. D. A. MacInnes and C. R. A. Catlow, J. Nucl. Mat. 89, 354 (1980).

20. L. Leibowitz, M. G. Chasanov, L. W. Mishler, and D. F. Fischer, J. Nuc1. Mat. 39 115-116 (1971).

21. D. L. Booth, "The Thermodynamic Properties of $\mathrm{UO}_{2}$ and Sodium" TRG Report 1871 [R/X] (1969).

22. J. O. Hirschfelder, R. J. Buehler, H. A. McGee, Jr., and J. R. Sutton, Ind. Eng. Chem. $\underline{50}, 375$ (1958). 
A 1.1 .2 .1

$12 / 80$

URANIUM DIOXIDE

$\mathrm{C}_{\mathrm{P}}$

Heat Capacity at Constant Pressure

\begin{tabular}{|c|c|}
\hline $\mathrm{T}, \mathrm{K}$ & $\mathrm{C}_{\mathrm{P}}, \mathrm{J} \cdot \mathrm{mol}^{-1} \cdot \mathrm{K}^{-1}$ \\
\hline 298.15 & 63.60 \\
\hline 300 & 63.79 \\
\hline 400 & 71.30 \\
\hline 500 & 75.48 \\
\hline 600 & 78.20 \\
\hline 700 & 80.17 \\
\hline 800 & 81.73 \\
\hline 900 & 83.05 \\
\hline 1000 & 84.22 \\
\hline 1100 & 85.29 \\
\hline 1200 & 86.29 \\
\hline 1300 & 87.25 \\
\hline 1400 & 88.21 \\
\hline 1500 & 89.21 \\
\hline 1600 & 90.31 \\
\hline 1700 & 91.64 \\
\hline 1800 & 93.33 \\
\hline 1900 & 95.59 \\
\hline 2000 & 98.68 \\
\hline 2100 & 102.9 \\
\hline 2200 & 108.5 \\
\hline 2300 & 116.0 \\
\hline 2400 & 125.8 \\
\hline 2500 & 138.1 \\
\hline 2600 & 153.6 \\
\hline $2670(\alpha)$ & 166.4 \\
\hline $2670(\beta)$ & 167.0 \\
\hline 2700 & 167.0 \\
\hline 2800 & 167.0 \\
\hline 2900 & 167.0 \\
\hline 3000 & 167.0 \\
\hline 3100 & 167.0 \\
\hline 3120 (s) & 167.0 \\
\hline 3120 (l) & 131.0 \\
\hline 3500 & 131.0 \\
\hline 4000 & $(131.0)^{*}$ \\
\hline 4500 & $(131.0)$ \\
\hline 5000 & $(131.0)$ \\
\hline 5500 & $(131.0)$ \\
\hline 6000 & $(131.0)$ \\
\hline
\end{tabular}

* Parentheses indicate extrapolation beyond the range of experimental data. 

A 1.1 .2 .2

Heat Capacity at Constant Volume

\begin{tabular}{|c|c|}
\hline $\mathrm{T}, \mathrm{K}$ & $\mathrm{C}_{\mathrm{V}}, \mathrm{J} \cdot \mathrm{mol}^{-1} \cdot \mathrm{K}^{-1}$ \\
\hline 298.15 & 62.90 \\
\hline 300 & 63.09 \\
\hline 400 & 70.23 \\
\hline 500 & 73.99 \\
\hline 600 & 76.20 \\
\hline 700 & 77.59 \\
\hline 800 & 78.49 \\
\hline 900 & 79.07 \\
\hline 1000 & 79.41 \\
\hline 1100 & 79.56 \\
\hline 1200 & 79.56 \\
\hline 1300 & 79.44 \\
\hline 1400 & 79.23 \\
\hline 1500 & 78.98 \\
\hline 1600 & 78.75 \\
\hline
\end{tabular}


A 1.1 .2 .3

$12 / 80$

URANIUM DIOXIDE

$\mathrm{C}_{\mathrm{V}}$

Heat Capacity at Constant Volume

\begin{tabular}{|c|c|}
\hline $\mathrm{T}, \mathrm{K}$ & $\mathrm{C}_{\mathrm{V}}, \mathrm{J} \cdot \mathrm{mol}^{-1} \cdot \mathrm{K}^{-1}$ \\
\hline 3120 (l) & 105.2 \\
\hline 3200 & $(105.8)^{\star}$ \\
\hline 3300 & $(106.6)$ \\
\hline 3400 & $(107.4)$ \\
\hline 3500 & $(108.2)$ \\
\hline 3600 & $(108.9)$ \\
\hline 3700 & $(109.6)$ \\
\hline 3800 & $(110.2)$ \\
\hline 3900 & $(110.9)$ \\
\hline 4000 & $(111.5)$ \\
\hline 4100 & $(112.0)$ \\
\hline 4200 & $(112.6)$ \\
\hline 4300 & $(113.2)$ \\
\hline 4400 & $(113.7)$ \\
\hline 4500 & $(114.3)$ \\
\hline 4600 & $(114.8)$ \\
\hline 4700 & $(115.3)$ \\
\hline 4800 & $(115.8)$ \\
\hline 4900 & $(116.4)$ \\
\hline 5000 & $(116.9)$ \\
\hline 5100 & $(117.4)$ \\
\hline 5200 & $(117.9)$ \\
\hline 5300 & $(118.4)$ \\
\hline 5400 & $(118.9)$ \\
\hline 5500 & $(119.4)$ \\
\hline 5600 & $(119.9)$ \\
\hline 5700 & $(120.4)$ \\
\hline 5800 & $(120.9)$ \\
\hline 5900 & $(121.4)$ \\
\hline 6000 & $(121.9)$ \\
\hline
\end{tabular}

* Parentheses indicate the parameters used in the calculation of $\mathrm{C}_{\mathrm{V}}$ have been extrapolated beyond the range of experimental data. 
A 1.1 .2 .4

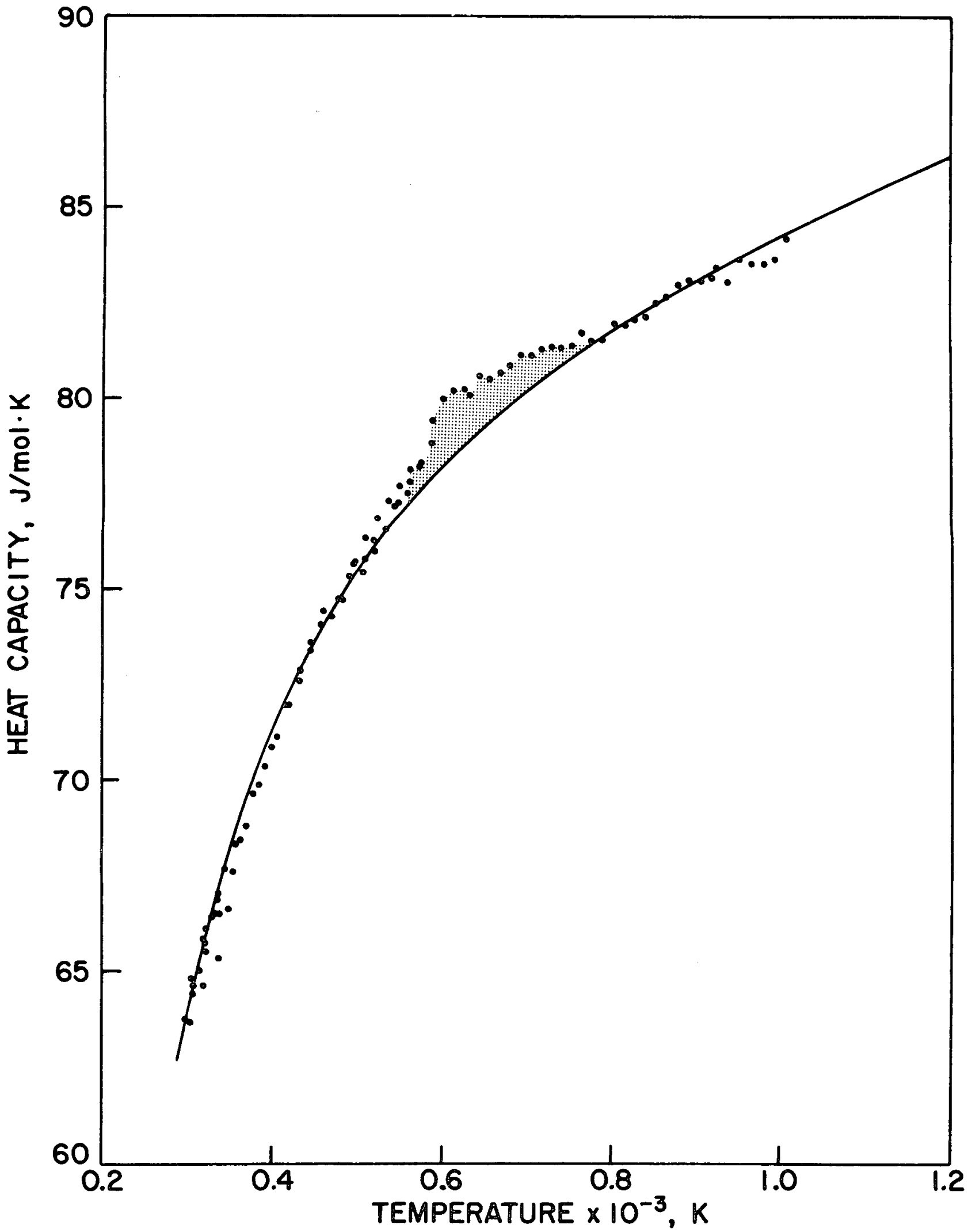

A comparison of the recommended heat capacity functions for $\mathrm{UO}_{2}$ with experimental data. The data points above the shaded area are due to high contamination of the $\mathrm{UO}_{2}$ by $\mathrm{U}_{4} \mathrm{O}_{9}$. 
A 1.1 .2 .5

$12 / 80$

URANIUM DIOXIDE

$\mathrm{C}_{\mathrm{V}}$

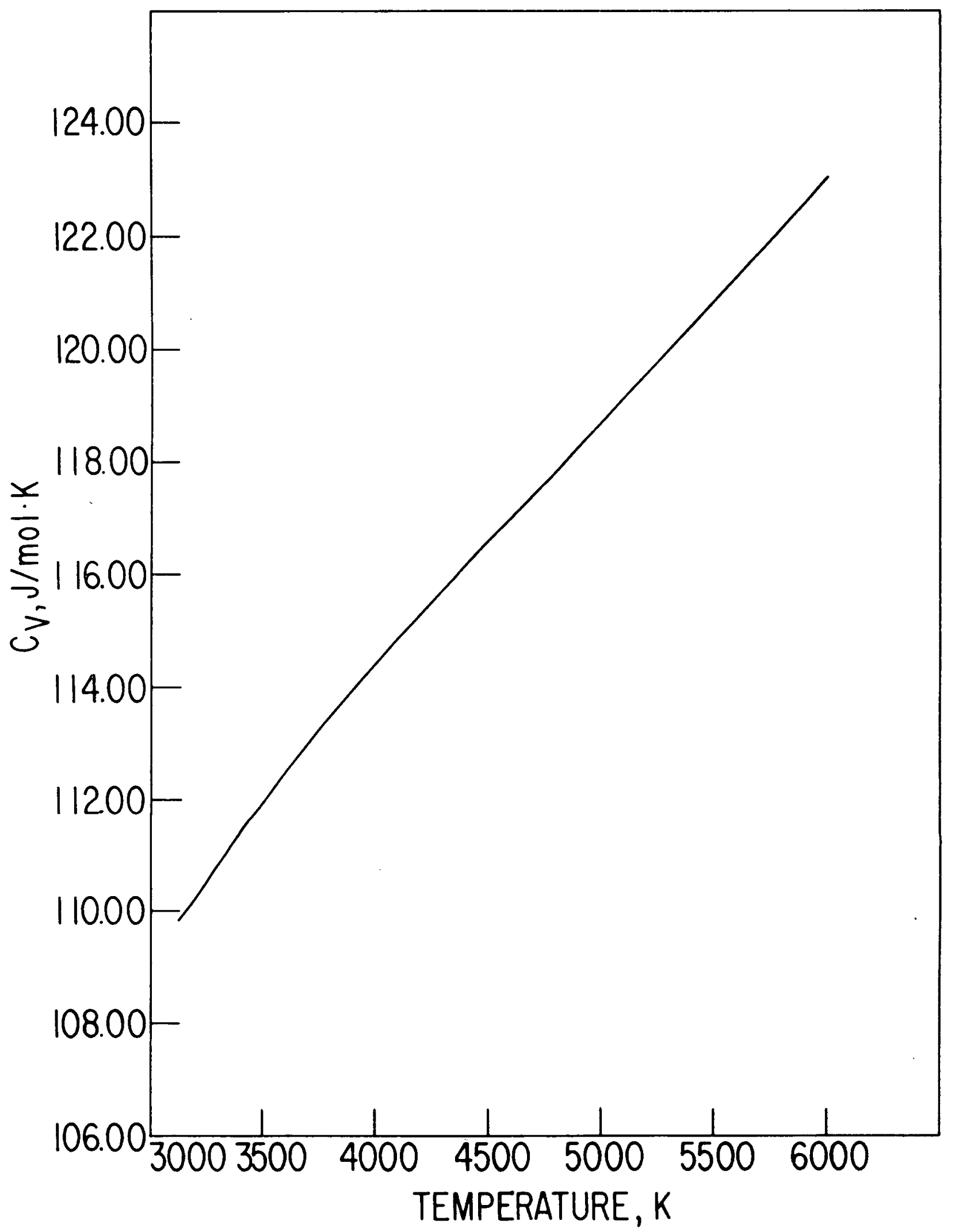

Heat capacity at constant volume of liquid $\mathrm{UO}_{2}$ 
Heat Capacity at Constant Pressure

$$
\begin{aligned}
298-2670 \text { (solid) } \frac{(78.212)(516.11)^{2} \exp \left(\frac{516.11}{\mathrm{~T}}\right)}{\mathrm{T}^{2}\left[\exp \left(\frac{516.11}{\mathrm{~T}}-1\right)\right]^{2}} \\
+2.0\left(3.8616 \times 10^{-3}\right) \mathrm{T} \\
+3.3993 \times 10^{8}\left(8.6144 \times 10^{-5}\right) \exp \left(\frac{-1.8815}{8.6144 \times 10^{-5} \mathrm{~T}}\right) \\
\\
\left(1+\frac{[\mathrm{T}-298.15] 1.8815}{8.6144 \times 10^{-5} \mathrm{~T}^{2}}\right)
\end{aligned}
$$


Heat Capacity at Constant Volume

\begin{tabular}{|c|c|c|}
\hline $\begin{array}{c}\text { Temperature Range } \\
\mathrm{T}, \mathrm{K}\end{array}$ & $\mathrm{C}_{\mathrm{V}}, \mathrm{J} \cdot \mathrm{mol}^{-1} \cdot \mathrm{K}^{-1}$ & $\begin{array}{c}\text { Error } \\
\sigma, \%\end{array}$ \\
\hline $298-1600$ (solid) & & 4 \\
\hline $3120-3400$ (11quid) & & 20 \\
\hline $3400-4000$ & $\mathrm{C}_{\mathrm{P}} \beta_{\mathrm{S}}{ }^{*}$ & 25 \\
\hline $4000-5000$ & $\beta_{\mathrm{T}}$ & 65 \\
\hline $5000-6000$ & & 120 (factor of 2.2) \\
\hline
\end{tabular}

${ }^{*}$ The methods used for the calculation of $\beta_{S}$ and $\beta_{T}$ are given in Section A 1.1.11. 


\section{A 1.1 .2 .8}

$8 / 80$

\section{Heat Capacity}

Data $^{1-14}$ over the range 298 to $3531 \mathrm{~K}$ can be used to obtain heat capacities for $\mathrm{UO}_{2}$. A selected set of these data $1,2,4-7,12,13$ were fit by Rand et a1. ${ }^{15}$ to a Kerrisk and Clifton-type equation ${ }^{16}$ (a modified Einstein term is included) from 298 to $2670 \mathrm{~K}$. From $2670 \mathrm{~K}$ to the melting point of $\mathrm{UO}_{2}$, a constant $\mathrm{C}_{\mathrm{P}}$ was obtained; similarly, a constant $\mathrm{C}_{\mathrm{P}}$ was also found for the liquid $\mathrm{UO}_{2}$ region.

The Kerrisk-Clifton equation used to fit the heat capacity consists of three terms.

$$
C_{P}=\frac{C_{1} \theta^{2} e^{\theta / T}}{T^{2}\left(e^{\theta / T}-1\right)^{2}}+2 C_{2} T+\frac{C_{3} E_{d}}{R T^{2}} e^{-E_{d} / R T}
$$

The first term which dominates at low temperature is due to the phonon contribution. The second term is a contribution due to volumetric thermal expansion. The third term contains the anomalous contribution not included in the first two. The form chosen for this last term in the Kerrisk-Clifton treatment was that due to Frenkel defects. Here $E_{d} / R$ is the activation temperature for formation of an anion Frenkel defect.

Young, ${ }^{17}$ MacInnes and Catlow, ${ }^{18}$ and Harding et al. ${ }^{19}$ have pointed out that it is more appropriate to attribute this anomalous contribution to electron effects. Young suggests that the third term should be of the form:

$$
C_{3} k\left(1+\frac{E_{a}}{k T}\right) e^{-E_{a} / k T}
$$




\section{A 1.1 .2 .9}

where $k$ is the Boltzmann constant and $E_{a}$ is the energy gap between the conduction and valence bands.

The enthalpy and heat capacity data for solid $\mathrm{UO}_{2}{ }^{1-13}$ have been reexamined by us. Comparisons were made with fits using (1) a KerriskClifton equation over the entire temperature range, (2) a Kerrisk-clifton formulation for the first two terms and an electronic term for the anomalous contribution, (3) the Rand formulation using two equations, and (4) the Rand formulation with an electronic term. We found that the data were best fit by (4) with a transition temperature of 2670 as proposed by Rand.

The recommended equations for heat capacity in $J /(\operatorname{mol} \cdot \mathrm{K})$ are:

for $298 \mathrm{~K} \leq \mathrm{T} \leq 2670 \mathrm{~K}$

$$
\begin{aligned}
C_{P}= & \frac{C_{1} \theta^{2} e^{\theta / T}}{T^{2}\left(e^{\theta / T}-1\right)^{2}}+2 C_{2} T \\
& +C_{3} k e^{-E_{a} / k T}\left[1+\frac{(T-298.15) E_{a}}{k T^{2}}\right]
\end{aligned}
$$

where $\mathrm{C}_{1}=78.212 \mathrm{~J} \cdot \mathrm{mol}^{-1} \cdot \mathrm{K},-1$

$$
\begin{aligned}
& \mathrm{C}_{2}=3.8616 \times 10^{-3} \mathrm{~J} \cdot \mathrm{mol}^{-1} \cdot \mathrm{K}^{-2}, \\
& \mathrm{C}_{3}=3.3993 \times 10^{8} \mathrm{~J} \cdot \mathrm{mol}^{-1} \cdot \mathrm{ev}^{-1}, \\
& \mathrm{E}_{\mathrm{a}}=1.8815 \mathrm{eV}, \\
& \theta=516.11 \mathrm{~K},
\end{aligned}
$$

and $\mathrm{k}=8.6144 \times 10^{-5} \mathrm{eV} / \mathrm{K}$ is the Boltzmann constant;

for $2670 \mathrm{~K} \leq \mathrm{T} \leq 3120 \mathrm{~K}$

$$
C_{P}=167.04
$$




\section{A 1.1 .2 .10}

$12 / 80$

URANIUM DIOXIDE

$\mathrm{C}_{\mathrm{P}}$

In Eqs. (3-4), $T$ is in kelvins. The slight deviation in form of the third term from that suggested by Young is due to the inclusion of the factor (T-298.15) in the corresponding enthalpy equation to satisfy the constraint that $H(T)-H(298.15)$ is zero at $T=298.15 \mathrm{~K}$. The condition $\mathrm{dH} / \mathrm{dT}(\mathrm{T}=$ $298.15)=15.20 \mathrm{cal} / \mathrm{mol} \cdot \mathrm{K}$ was used to constrain the five parameters, $\mathrm{C}_{1}, \mathrm{C}_{2}$, $C_{3}, E_{a}$, and $\theta$. Thus while five parameters are given, only four of them are independent.

In our fit to the enthalpy and heat capacity data, we first obtained a fit of the enthalpy data and then evaluated the corresponding equation for heat capacity with respect to the heat capacity data. In examining the experimental data we have chosen not to include some measurements in the fit. Of the five separate sets of enthalpy data examined, two sets were not included in the final fit of experimental data. In the region from about room temperature to $1500 \mathrm{~K}$ the measurements of Moore and Kelley ${ }^{3}$ and those of Ogard and Leary ${ }^{2}$ do not agree well with those of Fredrickson and Chasanov ${ }^{7}$. Because of the agreement of Fredrickson and Chasanov ${ }^{7}$ with Hein and Flagella ${ }^{6}$ who in turn agree well at higher temperatures with Leibowitz et al., ${ }^{1}$ we have selected the data of Fredrickson and Chasanov for use in the moderate temperature range. The heat capacity of Affortit 8,9 seem to be clearly at variance with those of several other experimenters and has not been included. Because the data of Popov et al. ${ }^{11}$ are high and that of Enge $1^{10}$ appear to have a systematic error, (it differs from data of other experimenters by a normalization) these two sets of data have not been included in the final assessment of the equation obtained from the fit to the enthalpy 
data. The recommended set of values would not change very much if we had included all the data.

In the figure comparing the recommended equation with experimental data, the data of Gronvold et al. ${ }^{12}$ in the temperature region 500 to $800 \mathrm{~K}$ are high. Gronvold stated that this was due to contamination of his sample of $\mathrm{UO}_{2}$ by $\mathrm{U}_{4} \mathrm{O}_{9}$ creating an excess of oxygen in his sample. The shaded area of the figure shows the contribution due to the solution of $\mathrm{U}_{4} \mathrm{O}_{9}$ in the sample.

For liquid $\mathrm{UO}_{2}$, the constant value obtained from Rand's ${ }^{14}$ fit to the liquid enthalpy and heat capacity data is recommended.

For $3120 \mathrm{~K} \leq \mathrm{T} \leq 3530 \mathrm{~K}$,

$$
\mathrm{C}_{\mathrm{P}}=130.95
$$

Above $3530 \mathrm{~K}$, it is assumed that $C_{P}$ is constant. Equations ( 3 ) through (5) define $C_{P}$ to be equal to $\left(\frac{\partial H}{\partial T}\right)_{S A T}$ which is not thermodynamically accurate. Thermodynamically $C_{P}$ is defined as $\left(\frac{\partial H}{\partial T}\right)_{P}$ or

$$
C_{P}=\left(\frac{\partial H}{\partial T}\right)_{S A T}-V \gamma_{S A T}+V T \alpha_{P} \gamma_{S A T}
$$

where $H$ is the enthalpy,

$\mathrm{V}$ is the volume,

$\alpha_{\mathrm{P}}$ is the instantaneous volumetric thermal expansion coefficient,

$$
\text { and } \gamma_{\text {SAT }}=\left(\frac{\partial \mathrm{P}}{\partial \mathrm{T}}\right)_{\mathrm{SAT}}
$$

However, for $\mathrm{UO}_{2}$ the terms $\mathrm{V}_{\mathrm{SAT}}$ and $\mathrm{V} T a_{\mathrm{P}} \gamma_{\mathrm{SAT}}$ which distinguish $\mathrm{C}_{\mathrm{P}}$ from $\left(\frac{\partial H}{\partial T}\right)_{\text {SAT }}$ are so small that they give no contribution to the order of significant figures quoted here. For the solid V $\gamma_{\text {SAT }}$ ranges from $4 \times 10^{-73}$ 
$\mathrm{J} / \mathrm{mol} \cdot \mathrm{K}$ at $400 \mathrm{~K}$ to $1 \times 10^{-6} \mathrm{~J} / \mathrm{mol} \cdot \mathrm{K}$ at $3120 \mathrm{~K}$ and $\mathrm{V} \mathrm{T} \alpha_{\mathrm{P}} \gamma_{\mathrm{SAT}}$ ranges from $4 \times 10^{-75} \mathrm{~J} / \mathrm{mol} \cdot \mathrm{K}$ at $400 \mathrm{~K}$ to $2 \times 10^{-7} \mathrm{~J} / \mathrm{mol} \cdot \mathrm{K}$ at $3120 \mathrm{~K}$ so they are insignificant compared to $\left(\frac{\partial \mathrm{H}}{\partial \mathrm{T}}\right)_{\mathrm{SAT}}$.

For liquid $\mathrm{UO}_{2}, \mathrm{~V} \gamma_{\mathrm{SAT}} \alpha_{\mathrm{P}} \mathrm{T}$ ranges from $3.2 \times 10^{-7} \mathrm{~J} / \mathrm{mol} \cdot \mathrm{K}$ at $3120 \mathrm{~K}$ to $9.0 \times 10^{-4} \mathrm{~J} / \mathrm{mol} \cdot \mathrm{K}$ at $6000 \mathrm{~K}$ and $\mathrm{V} \gamma_{\mathrm{SAT}}$ ranges from $1.1 \times 10^{-6}$ $\mathrm{J} / \mathrm{mol} \cdot \mathrm{K}$. In this temperature range, $\left(\frac{\partial \mathrm{H}}{\partial \mathrm{T}}\right)_{\mathrm{SAT}}=130.95 \mathrm{~J} / \mathrm{mol} \cdot \mathrm{K}$. Thus, even

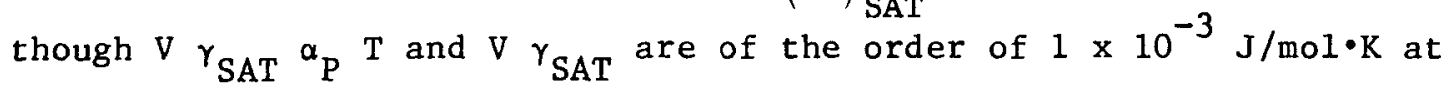
$6000 \mathrm{~K}$, these values are still smaller than the number of significant figures being retained in the calculation, and thus, make no significant contribution to $C_{P}$ in the temperature range 3120 to $6000 \mathrm{~K}$. Thus, for the temperature range $298-6000 \mathrm{~K}, \mathrm{C}_{\mathrm{P}}$ may be approximated as

$$
C_{P} \simeq\left(\frac{\partial H}{\partial T}\right)_{S A T}
$$

with no additional error within $10^{-2}$.

The heat capacity of $\mathrm{UO}_{2}$ is not expected to vary markedly with oxygen stoichiometry. Moreover, the data which are available are insufficient for recommending a quantitative relationship containing the effect of oxygen stoichiometry. 8

The use of two equations for the solid phase heat capacity is based on physical observations ${ }^{20}$ of changes in $\mathrm{UO}_{2}$ texture close to $2700 \mathrm{~K}$, Bredig's arguments ${ }^{21}$ that there is a high probability of a phase transition in $\mathrm{UO}_{2}$ below the melting point (as is found in other compounds with a fluorite structure), and analysis of the experimental data which indicates a better fit above $2700 \mathrm{~K}$ using a constant $C_{P}$. The transition postulated by Bredig 21 at $2670 \mathrm{~K}$ is equivalent to a "melting" of the 
A 1.1 .2 .13

$12 / 80$

URANIUM DIOXIDE

$\mathrm{C}_{\mathrm{P}}$

anion lattice while the uranium lattice remains until the melting point at $3120 \mathrm{~K}$. This behavior corresponds to a second-order or a lambda transition; however, the $\mathrm{UO}_{2}$ experimental data have here for simplicity been treated as though the transition were first order.

For solid $\mathrm{UO}_{2}$ in the temperature range 298 to $2670 \mathrm{~K}$, the standard deviation $(1 \sigma)$ in the $\mathrm{UO}_{2}$ heat capacity data and that from a least squares fit to that data is $\pm .6 \%$. Between $2670 \mathrm{~K}$ and the melting point $(3120 \mathrm{~K})$, the error is estimated as $\pm 1 \%$. For molten $\mathrm{UO}_{2}$, the error $(1 \sigma)$ is estimated as $1 \%$ in the temperature interval 3120 to $3500 \mathrm{~K}, 10 \%$ in the temperature interval 4000 to $5000 \mathrm{~K}$, and $20 \%$ in the temperature interval 5000 to $6000 \mathrm{~K}$. 


\section{Heat Capacity at Constant Volume}

The heat capacity at constant volume, $C_{V}$, may be calculated from the heat capacity at constant pressure, $C_{P}$, using the thermodynamic relation ${ }^{22}$

$$
C_{V}=C_{P} \frac{{ }^{B} S}{\beta_{T}}
$$

where $\beta_{T}$ is the isothermal compressibility and $\beta_{S}$ is the adiabatic compressibility.

The isothermal compressibility, ${ }_{\mathrm{T}}$ of $\mathrm{UO}_{2}$, was evaluated using the relation 20

$$
\beta_{\mathrm{T}}=\beta_{\mathrm{S}}+\frac{\alpha_{\mathrm{P}}{ }^{2} \mathrm{VT}}{\mathrm{C}_{\mathrm{P}}}
$$

The volumetric thermal expansion coefficient for solid $\mathrm{UO}_{2}$ in $\mathrm{K}^{-1}$ is given by the equation 23,24

$$
\alpha_{P}=\frac{1.7169 \times 10^{-5}+1.4928 \times 10^{-8} \mathrm{~T}+1.0260 \times 10^{-12} \mathrm{~T}^{2}}{0.9989695+5.723 \times 10^{-6} \mathrm{~T}+2.488 \times 10^{-9} \mathrm{~T}^{2}+1.140 \times 10^{-13} \mathrm{~T}^{3}}
$$

The volumetric expansion coefficient for liquid $\mathrm{UO}_{2}$ is $^{23,24}$

$$
\alpha_{P}=\frac{1.05 \times 10^{-4}}{1+3.5 \times 10^{-5}(T-3120)} K^{-1}
$$

The adiabatic compressibility for solid $\mathrm{UO}_{2}$ was calculated from Young's modulus (E) and Poisson's ratio $(\sigma)$ using the relation

$$
{ }_{S} S=\frac{3(1-2 \sigma)}{E} .
$$




\section{A 1.1 .2 .15}

Below $1600 \mathrm{~K}$, Young's modulus is given by the equation 25

$$
E=2.26 \times 10^{11}\left[1-1.31 \times 10^{-4}(\mathrm{~T}-273.15)\right][1-2.62(1-\mathrm{D})]
$$

where

$$
\begin{aligned}
E & =\text { Young's modulus in pascals, } \\
T & =\text { temperature in } K, \\
\text { and } D & =\text { fraction of theoretical density. }
\end{aligned}
$$

The value used for Poisson's ratio ${ }^{26}$ is 0.316 .

Above $1600 \mathrm{~K}$, there is no recommended equation for Young's modulus because of insufficient data. Thus, $\mathrm{C}_{\mathrm{V}}$ for solid $\mathrm{UO}_{2}$ is not calculated above $1600 \mathrm{~K}$. From 3120 through $3200 \mathrm{~K}$, B ${ }_{\mathrm{S}}$ may be calculated from the speed of sound (v) using a fit to the slagle-Nelson data ${ }^{27}$ and from the density $(\rho)$ of Christensen ${ }^{23,24}$ using the relations

$$
\begin{gathered}
{ }^{\beta} S=\frac{1}{\rho V^{2}} \\
\rho=10970\left(1.0522-8.192 \times 10^{-5} \mathrm{~T}\right) \\
v=3660-0.5769 \mathrm{~T}
\end{gathered}
$$

where $T$ is in kelvins, $\rho$ is in $\mathrm{kg} / \mathrm{m}^{3}, v$ is $1 \mathrm{n} \mathrm{m} / \mathrm{s}$, and ${ }_{\mathrm{S}}$ is in $\mathrm{Pa}^{-1}$. Above $3200 \mathrm{~K},{ }_{\mathrm{S}}$ may be approximated using the Grosse ${ }^{28}$ technique

$$
{ }_{S} S=\frac{{ }^{\beta} S, m}{\frac{a}{\theta+b}-b}
$$

where

$$
\beta_{S, m}=3.3 \times 10^{-11} \mathrm{~Pa}^{-1}
$$


is the adiabatic compressibility at the melting point. $\theta$ is the reduced temperature defined by

$$
\theta=\frac{T-T_{m}}{T_{C}-T_{m}}
$$

where $T_{m}=3120 \mathrm{~K}$, is the melting point and $T_{C}$ is the critical point (estimated as $7560 \mathrm{~K}$ ). ${ }^{29}$

The parameters $a$ and $b$ determined using the Grosse equilateral hyperbola method with the existing data are

$$
\begin{aligned}
& a=0.5633 \\
& b=0.4018
\end{aligned}
$$

Because of the uncertainty of the value of the critical temperature, the limited data ( 4 points), and limited temperature range $3120-3200 \mathrm{~K}$ upon which this extrapolation technique is based, it is expected to be unreliable at high temperatures. Consequently, values of $C_{V}$ above $3200 \mathrm{~K}$ should be taken only as estimates. The large estimated errors reflect this uncertainty.

The standard deviations $(\sigma)$ expressed as a percent for the heat capacity at constant volume, $C_{V}$, have been calculated from the standard deviations of the dependent parameters of $E q$. (9) namely $C_{P}, \beta_{S}$, and ${ }_{T}^{\beta_{T}}$. Because of the large uncertainty in the calculation of ${ }^{\beta_{S}}$ and ${ }^{B_{T}}$ above $3400 \mathrm{~K}$, there is also a large uncertainty in the estimated values for $\mathrm{C}_{\mathrm{V}}$ above $3400 \mathrm{~K}$. The estimated standard deviation of recommended values of $\mathrm{C}_{\mathrm{V}}$ for solid $\mathrm{UO}_{2}$ is $4 \%$. For liquid $\mathrm{UO}_{2}$ between 3120 and $3400 \mathrm{~K}$, the estimated standard deviation is $20 \%$. From 3400 to $4000 \mathrm{~K}$, 
A 1.1 .2 .17

$12 / 80$

URANIUM DIOXIDE

$\mathrm{C}_{\mathrm{V}}$

this standard deviation increases to $25 \%$. The error in the values of $\mathrm{C}_{\mathrm{V}}$ in the temperature range $4000-5000 \mathrm{~K}$ is estimated as a factor of 1.3 or equivalently the standard deviation is $60 \%$. Above $5000 \mathrm{~K}$, the values are estimated to be correct within a factor of 2.20 , i.e., they have a standard deviations of $120 \%$. 


\section{References}

1. L. Leibowitz, L. W. Mishler, and M. G. Chasanov, J. Nuc1. Mat. 29, 356 (1969).

2. A. E. Ogard and J. A. Leary, "Thermodynamics of Nuclear Materials-1967," IAEA, Vienna, p. 651, 1969.

3. G. E. Moore and K. K. Kelley, J. Am. Chem. Soc. 69, 2105 (1974).

4. R. A. Hein, L. H. Sjodahl, and R. Szwarc, J. Nuc1. Mat. 25, 99 (1968).

5. J. B. Conway and R. A. Hein, J. Nucl. Mat. 15, 149 (1965).

6. R. A. Hein and P. N. Flagella, "Enthalpy Measurements of $\mathrm{UO}_{2}$ and Tungsten to $3260^{\circ} \mathrm{K}$," General Electric report GEMP-578, February 16 (1980).

7. D. R. Fredrickson and M. G. Chasanov, J. Chem. Thermodynamics 2 , 263 (1970).

8. C. A. Affortit and J. Marcon, Rev. Int. Hautes Temp. et Refract. $\underline{7}$, $236(1970)$.

9. C. Affortit, High Temperatures - High Pressures 1, 27-33 (1969).

10. T. K. Enge1, J. Nuc1. Mat. 31, 211 (1969).

11. M. M. Popov, G. L. Gal'chenko, and M. D. Seniv, Zh. Neorg. Khim $\underline{3}$, 1734-1737 (1958), Trans. J. Inorganic Chem., USSR, 18-22 (1958).

12. F. Gronvold, M. H. Kreseth, A. Sveen, and J. Tichý, J. Chem. Thermodynamics 2, 665-679 (1970).

13. J. J. Hunzicker and E. F. Westrum, J. Chem. Thermodynamics 3, 61 (1971). 
A 1.1 .2 .19

$12 / 80$

URANIUM DIOXIDE

References (Cont'd)

14. L. Leibowitz, M. G. Chasanov, L. W. Mishler, and D. F. Fischer, J. Nuc1. Mat. 39, 115-116 (1971).

15. M. H. Rand, R. J. Ackermann, F. Grфnvold, F. L. Oetting, and A. Pattoret, Rev. Int. Hautes Temp. et Refract. 15. 355 (1978).

16. J. F. Kerrisk and D. G. Clifton, Nuc1. Tech. 16, 531 (1972).

17. R. A. Young, J. Nuc1. Mat. 87, 283-296 (1979).

18. D. A. MacInnes and C. R. A. Catlow, J. Nucl. Mat. 89, 354 (1980).

19. J. H. Harding, P. Masri, and A. M. Stoneham, J. Nuc1. Mat. 92, 73 (1980)

20. R. J. Ackermann, P. W. Gilles, and R. J. Thorn, J. Chem. Phys. 25, 1089 (1956).

21. M. A. Bredig, Coll. Int. sur 1'etude des transformations crystalline a haute temperature, Odeillo, p. 183 (1971).

22. J. S. Rowlinson, Liquids and Liquid Mixtures, 2nd Ed., Butterworth \& Co., Ltd., London (1968).

23. J. A. Christensen, J. Am. Ceram. Soc. 40, 607 (1963).

24. 0. D. Slagle, Private Communication (December 1980).

25. D. L. Hagrman and G. A. Reymann, ed. "MATPRO-VERSION 11: A. Handbook of Materials Properties for Use in the Analysis of Light Water Reactor Fue1 Rod Behavior," NUREG/CR-0497, TREE-1280, Idaho National Engineering Laboratory (February 1979).

26. J. B. Wachtman, Jr., M. L. Wheat, H. J. Anderson, and J. L. Bates, J. Nuc1. Mat. 16, 39 (1965).

27. O. D. Slagle and R. P. Nelson, J. Nucl. Mater. 40, 349 (1971).

28. A. V. Grosse, Nature 232, 170 (1971).

29. E. A. Fischer, P. Kinsman, and R. W. Ohse, J. Nucl. Mat. 59, 125 (1976). 
A 1.1 .3 .1

$12 / 80$

URANIUM DIOXIDE

$\mathrm{T}_{\mathrm{m}}$

\section{Melting Point ${ }^{*}$}

Rand et al. ${ }^{1}$ have recently analyzed fourteen experimental studies (spanning a period of 20 years) dealing with the melting temperature of $\mathrm{UO}_{2}$; they note that the range of these values has decreased with time. The value recommended by Rand et al. ${ }^{1}$ is:

$$
\mathrm{T}_{\mathrm{m}}=3120 \pm 30 \mathrm{~K}
$$

This value has been accepted as the melting point by international agreement. The work completed prior to 1965 has been summarized by Hausner ${ }^{2}$; more recent data have been reported by Latta and Fryxel1 ${ }^{3}$, Lyon and Baily ${ }^{4}$, and Bates". Measurements have been made using "V" filament and thermal arrest methods. The data from the latter method are generally more reliable since the sample is encapsulated and vaporization is not a problem. Bates 5 used the "V" filament method since his work was aimed at irradiated materials. Of the data from thermal arrest measurements, the data of Latta and Fryxel1 ${ }^{3}$ appear to be the best. Their value agrees within experimental errors with the value reported earlier by Lyon and Bailey ${ }^{4}$, who used the same methods. Latta and Fryxell ${ }^{3}$ also report reasonably reliable data for the effect of oxygen stoichiometry on melting temperature in the range $-0.50<\mathrm{X}<0.20$ for $\mathrm{UO}_{2+\mathrm{X}}$.

Some of the values reported for $\mathrm{T}_{\mathrm{m}}$ are given below:

Hausner $^{2}$
Lyon and Baily
Latta and Fryxel1 $\mathrm{T}_{\mathrm{m}}, \mathrm{K}$ $3078 \pm 15$ $3113 \pm 20$ $3138 \pm 15$

* Parts of this section have been contributed by R. Gibby, Hanford Engineering Development Laboratory, Richland, WA. 
A 1.1 .3 .2

$12 / 80$

URANIUM DIOXIDE

$\mathrm{T}_{\mathrm{m}}$

The uncertainty in the recommended melting temperatures is $\pm 1 \%(1 \sigma)$. The experimental results of Latta and Fryxel1 ${ }^{3}$ and that of Lyon and Bailey $^{4}$ are well within this error estimate. 


$$
\text { A } 1.1 .3 .3
$$

$12 / 80$

URANIUM DIOXIDE

$T_{\mathrm{m}}$

\section{$\underline{\text { References }}$}

1. M. H. Rand, R. J. Ackermann, F. Grфnvold, F. L. Oetting, and A.

Pattoret, Rev. Int. Haute Temp. et Refract. 15, pp. 355-365 (1978).

2. A. Hausner, J. Nucl. Mat. 15, pp. 179-183 (1965).

3. R. E. Latta and R. E. Fryxe11, J. Nuc1. Mat. 35, pp. 195-210 (1970).

4. W. L. Lyon and W. E. Bailey, J. Nucl. Mat. 22, pp. 332-339 (1967).

5. J. L. Bates, J. Nucl. Mat. 36, pp. 234-236 (1970).

6. R. E. Latta and R. E. Fryxe11, Trans. ANS. $\underline{8}$ (2) (1965). 
A $1.1 .4 \cdot 1$

Heat of Fusion*

$74.8 \pm 1 \mathrm{~kJ} \cdot \operatorname{mol} 1^{-1}$

The heat of fusion for $\mathrm{UO}_{2}$ was calculated using equations ${ }^{1,2}$ for the enthalpy of $\mathrm{UO}_{2}$ :

$$
\begin{aligned}
& 2670 \leq \mathrm{T} \leq 3120 \mathrm{~K}, \quad \mathrm{H}(\mathrm{T})-\mathrm{H}(298.15)=167.04 \mathrm{~T}-218342 ; \\
& 3120 \leq \mathrm{T} \leq 3530 \mathrm{~K}, \quad \mathrm{H}(\mathrm{T})-\mathrm{H}(298.15)=130.95 \mathrm{~T}-30911 .
\end{aligned}
$$

In Eqs. (1) and (2) enthalpy is in $\mathrm{J}^{\cdot} \mathrm{mol}^{-1}$ and temperature in kelvins. Evaluation of these expressions at $3120 \mathrm{~K}$ provides a value of 74.8 $\mathrm{kJ} \cdot \mathrm{mol}^{-1}$ for the enthalpy of fusion with a standard deviation of $1 \%$. This recommended value for the heat of fusion is consistent with the recommended enthalpy data for $\mathrm{UO}_{2}$ and with experimental results of enthalpy measurements of Chikalla, ${ }^{3}$ Leibowitz et al.,$^{4}$ and Hein and Flagella. 5

Parts of this section were contributed by R. Gibby, Hanford Engineering Development Laboratory, Richland, WA. 
A 1.1 .4 .2

$12 / 80$

\section{References}

1. M. H. Rand, R. J. Ackermann, F. Grønvold, F. L. Oetting, and

A. Pattoret, Rev. Int. Hautes Temp. et Refract. 15, 355 (1978).

2. J. K. Fink and L. Leibowitz, "Enthalpy and Heat Capacity of $\mathrm{UO}_{2}$ " (to be published).

3. T. D. Chikalla, HW-69832 (1961).

4. L. Leibowitz, M. G. Chasanov, L. W. Mishler, and D. F. Fischer, J. Nucl. Mat. 39, pp. 115-116 (1971).

5. R. A. Hein and P. N. Flagella, GEMP-578 (1968). 

A 1.1 .5 .1

$12 / 80$

Vapor Pressure over Solid Uranium Dioxide

\begin{tabular}{|c|c|c|}
\hline$\underline{T, K}$ & $\mathrm{P}, \mathrm{MPa}$ & $\mathrm{P}$, atm \\
\hline 1500 & $8.27 \times 10^{-14}$ & $8.17 \times 10^{-13}$ \\
\hline 1600 & $1.66 \times 10^{-12}$ & $1.64 \times 10^{-11}$ \\
\hline 1700 & $2.35 \times 10^{-11}$ & $2.32 \times 10^{-10}$ \\
\hline 1800 & $2.48 \times 10^{-10}$ & $2.44 \times 10^{-9}$ \\
\hline 1900 & $2.03 \times 10^{-9}$ & $2.01 \times 10^{-8}$ \\
\hline 2000 & $1.35 \times 10^{-8}$ & $1.34 \times 10^{-7}$ \\
\hline 2100 & $7.53 \times 10^{-8}$ & $7.43 \times 10^{-7}$ \\
\hline 2200 & $3.58 \times 10^{-7}$ & $3.53 \times 10^{-6}$ \\
\hline 2300 & $1.49 \times 10^{-6}$ & $1.47 \times 10^{-5}$ \\
\hline 2400 & $5.48 \times 10^{-6}$ & $5.41 \times 10^{-5}$ \\
\hline 2500 & $1.82 \times 10^{-5}$ & $1.80 \times 10^{-4}$ \\
\hline 2600 & $5.51 \times 10^{-5}$ & $5.44 \times 10^{-4}$ \\
\hline 2700 & $1.54 \times 10^{-4}$ & $1.52 \times 10^{-3}$ \\
\hline 2800 & $3.99 \times 10^{-4}$ & $3.94 \times 10^{-3}$ \\
\hline 2900 & $9.69 \times 10^{-4}$ & $9.56 \times 10^{-3}$ \\
\hline 3000 & $2.22 \times 10^{-3}$ & $2.19 \times 10^{-2}$ \\
\hline 3100 & $4.81 \times 10^{-3}$ & $4.75 \times 10^{-2}$ \\
\hline 3120 & $5.59 \times 10^{-3}$ & $5.52 \times 10^{-2}$ \\
\hline
\end{tabular}



A 1.1 .5 .2

Vapor Pressure over Liquid Uranium Dioxide

\begin{tabular}{|c|c|c|}
\hline $\mathrm{T}, \mathrm{K}$ & $\mathrm{P}, \mathrm{MPa}$ & $P$, atm \\
\hline 3120 & 0.00559 & 0.0552 \\
\hline 3200 & 0.00923 & 0.0911 \\
\hline 3300 & 0.0166 & 0.164 \\
\hline 3400 & 0.0288 & 0.284 \\
\hline 3500 & 0.0480 & 0.474 \\
\hline 3600 & 0.0776 & 0.766 \\
\hline 3700 & 0.122 & 1.20 \\
\hline 3800 & 0.185 & 1.83 \\
\hline 3900 & 0.275 & 2.72 \\
\hline 4000 & 0.400 & 3.95 \\
\hline 4100 & 0.568 & 5.61 \\
\hline 4200 & 0.791 & 7.81 \\
\hline 4300 & 1.08 & 10.7 \\
\hline 4400 & 1.45 & 14.3 \\
\hline 4500 & 1.92 & 19.0 \\
\hline 4600 & 2.50 & 24.7 \\
\hline 4700 & 3.22 & 31.7 \\
\hline 4800 & 4.08 & 40.3 \\
\hline 4900 & 5.11 & 50.5 \\
\hline 5000 & 6.34 & 62.5 \\
\hline 5100 & $(7.77)^{*}$ & $(76.7)^{*}$ \\
\hline 5200 & $(9.43)$ & $(93.0)$ \\
\hline 5300 & $(11.3)$ & (112) \\
\hline 5400 & $(13.5)$ & (133) \\
\hline 5500 & $(16.0)$ & (158) \\
\hline 5600 & $(18.7)$ & (185) \\
\hline 5700 & $(21.8)$ & (215) \\
\hline 5800 & $(25.2)$ & (249) \\
\hline 5900 & $(29.0)$ & $(286)$ \\
\hline 6000 & $(33.1)$ & $(326)$ \\
\hline
\end{tabular}




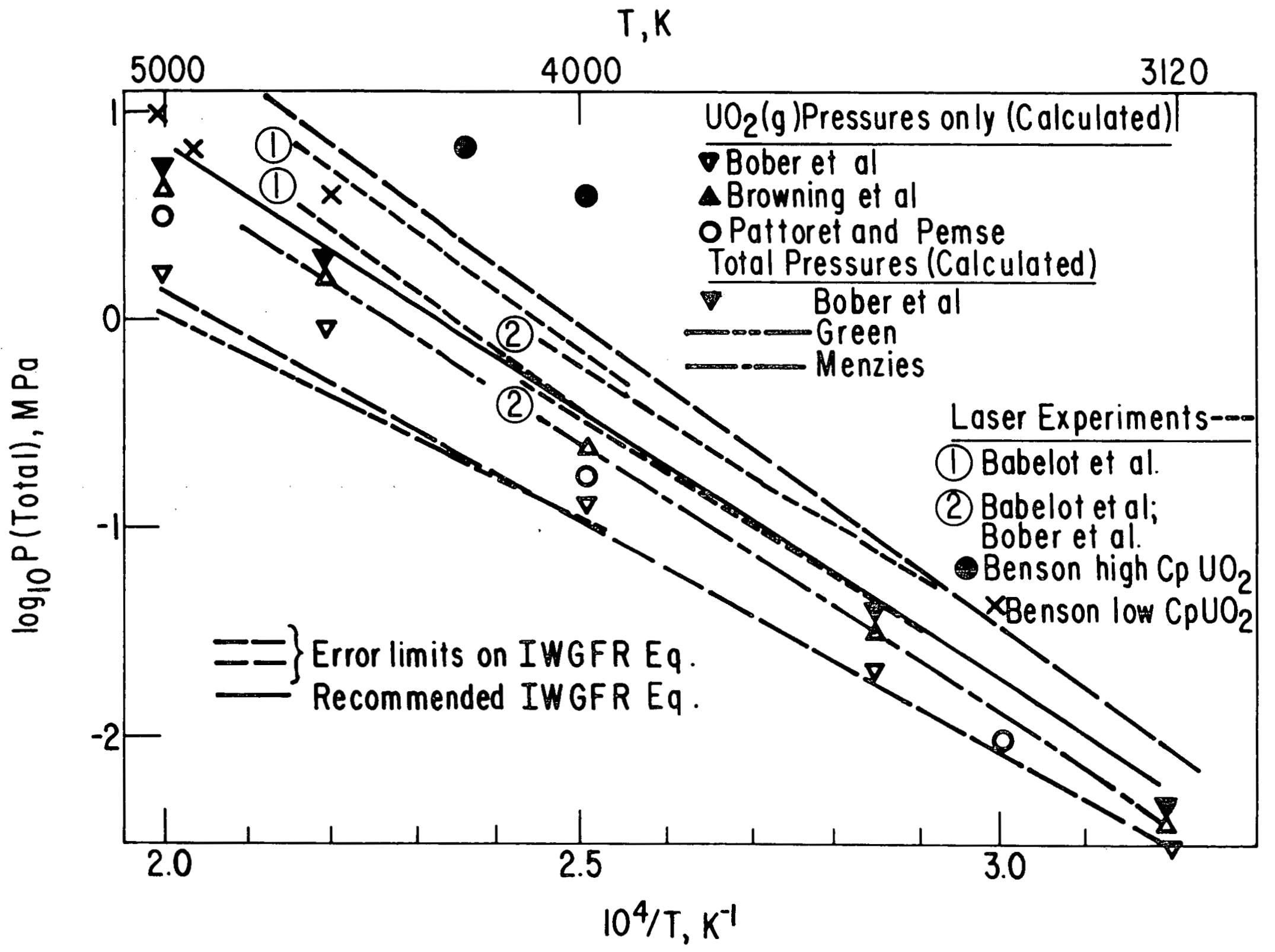

The total vapor pressure over $\mathrm{UO}_{2}$. The figure was adapted from reference 16 with data from references $7,8,10,13$, and 16 through 22 . 


\section{Vapor Pressure}

\section{Temperature Range}

$$
\mathrm{T}, \mathrm{K}
$$

be low 3120

$$
\frac{-31284}{T}+7.774
$$

$\left.\begin{array}{l}3120-4000 \\ 4000-5000 \\ 5000-6000\end{array}\right\}$
Error in

$\log \mathrm{P} \sigma$,

0.4

0.2

0.6

1.0
Error in

$P \sigma, \%$ 


\section{Vapor Pressure}

There have been many experimental determinations of the vapor pressure over solid $\mathrm{UO}_{2}$, notably the work of Ackermann, et al., ${ }^{1}$ Ohse, ${ }^{2}$ Tetenbaum and Hunt, ${ }^{3}$ and Pattoret et al. ${ }^{4}$ The pressures over 1 iquid UO 2 have been measured by Reedy and Chasanov, ${ }^{5}$ Ohse, et al., 6 Bober, et al., ${ }^{7}$ and Benson. ${ }^{8}$ These experimental measurements have extended to about $6000 \mathrm{~K}$. In addition to these direct determinations of $\mathrm{UO}_{2}$ vapor pressures there have been many indirect estimates of the pressures. Gabelnick ${ }^{9}$ and Green ${ }^{10,11}$ have calculated pressures over $\mathrm{UO}_{2}$ based on matrix-isolation spectroscopic study of gas phase uranium oxides. $\mathrm{VO}_{2}$ vapor pressures have also been calculated using corresponding states theory, ${ }^{12,13}$ significant structures theory, ${ }^{14}$ and oxygen potential thermodynamics. ${ }^{15}$ At a recent meeting ${ }^{16}$ of specialists at Harwell, the available uranium dioxide pressure data were reviewed and an equation for the pressures over liquid $\mathrm{UO}_{2}$ was recommended for use up to $5000 \mathrm{~K}$. This equation is given below, along with a slightly modified version of the equation of Tetenbaum and Hunt ${ }^{3}$ for pressures over solid $\mathrm{UO}_{2}$.

These equations for the base 10 logarithm of the total vapor pressure over $\mathrm{UO}_{2}$ are:

below $3120 \mathrm{~K}$ (solid);

$$
\log P=-\frac{31284}{T}+7.774
$$

$3120-5000 \mathrm{~K}$ (1iquid),

$$
\log P=28.65-\frac{34930}{\mathrm{~T}}-5.64 \log \mathrm{T} .
$$

where $P$ is in MPa and $T$ is in kelvins. 
Above $5000 \mathrm{~K}$, the situation is unresolved; the table below presents calculated values at 5000 and $6000 \mathrm{~K}$ based on the work of various investigators.

Table I. Calculated Vapor Pressure

Source $\quad \underline{\text { Reference }} \quad \underline{P}$ at $5000 \mathrm{~K}$, atm $\quad \underline{P}$ at $6000 \mathrm{~K}$, atm

Eq. (2)

Ohse

Gabelnick

Booth

Menzies

Breitung

Gillan

Benson

Green

16

6

9

12

13

15

14

8

10
62.5

13.0

29.1

98.9

46.5

150 .

33.1

86.1

21.5
327

1120

171

554

272

151

404

137

The mean of the tabulated values at $5000 \mathrm{~K}$ [excluding $\mathrm{Eq} .(2)$ ] is 60 atm with a standard deviation of $45 \mathrm{~atm}$; this is comparable to the $62.5 \mathrm{~atm}$ predicted by Eq. (2). At $6000 \mathrm{~K}$, the mean of the various investigators' estimates is 403 atm with a standard deviation of about 324 atm; this is in reasonable agreement with the value calculated using Eq. (2).

Most of these studies have not allowed for the fact that the vapor in equilibrium with $\mathrm{UO}_{2}$ does not simply consist of $\mathrm{UO}_{2}$ molecules but is a complex mixture of $0, \mathrm{O}_{2}, \mathrm{U}, \mathrm{UO}, \mathrm{UO}_{2}$, and $\mathrm{UO}_{3}$ molecules. The vapor composition and pressure both depend on the condensed phase composition and temperature. Vapor pressures have been calculated by Gabelnick ${ }^{9}$ and by Green and Leibowitz ${ }^{11}$ which take this variation into account. 


\section{A 1.1 .5 .7}

$12 / 80$

The error $(1 \sigma)$ in the values for the logarithm of the vapor pressure above solid $\mathrm{UO}_{2}(\mathrm{Eq} \cdot(1)$ ) is 0.4 . The standard deviation ( $1 \sigma$ ) for the logarithm of the vapor pressure over liquid $\mathrm{UO}_{2}$ (Eq. (2)) ranges from \pm 0.2 at $3120 \mathrm{~K}$ to 0.6 at $5000 \mathrm{~K}$. Between $5000 \mathrm{~K}$ and $6000 \mathrm{~K}$, the standard deviation is estimated as 1.0 . These standard deviations for the logarithm of the pressure correspond to large errors in the calculated values of the

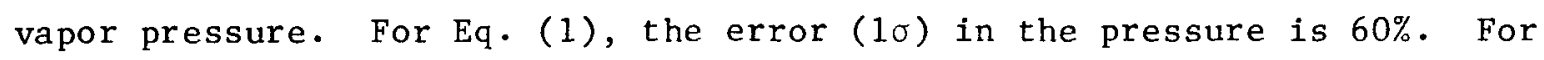
Eq. (2), below $4000 \mathrm{~K}$, the error in the vapor pressure values is $60 \%$, between 4000 and $5000 \mathrm{~K}$, it rises to $300 \%$ (a factor of 4) and to $900 \%$ (a factor of 10 ) at $6000 \mathrm{~K}$. 


$$
\text { A } 1.1 .5 .8
$$

$12 / 80$

\section{References}

1. a. R. J. Ackermann, P. W. Gilles, and R. J. Thorne, J. Chem. Phys. 25, $1089(1956)$.

b. R. J. Ackermann, E. G. Rauh, and M. H. Rand, "A Redetermination and Reassessment of the Thermodynamics of Sublmation of Uranium Dioxide," J. Nuc1. Mat. (in press).

2. R. W. Ohse, J. Chem. Phys. 44, 1375 (1966).

3. M. Tetenbaum and P. D. Hunt, J. Nuc1. Mat. 34, 86 (1970).

4. A. Pattoret. I. Drowart, and S. Smoes, "Thermodynamic of Nuclear Materials 1967," p. 613, International Atomic Energy Agency, Vienna (1967).

5. G. T. Reedy and M. G. Chasanov, J. Nuc1. Mat. $\underline{42}, 341$ (1972).

6. R. W. Ohse, P. G. Berrie, H. G. Bogensberger, and E. A. Fischer, "Thermodynamics of Nuclear Materials 1974," Vo1. I, p. 307, International Atomic Energy Agency, Vienna (1975).

7. M. Bober, H. V. Karow, and K. Schretzmann, Nuclear Technol. 26, 237 (1975).

8. D. A. Benson, "Application of Pulsed Electron Beam Vaporization to Studies of $\mathrm{UO}_{2}, "$ SAND-77-0429 (1977).

9. M. G. Chasanov, D. F. Fischer, D. R. Fredrickson, S. D. Gabelnick, R. Kumar, L. Leibowitz, G. T. Reedy, F. A. Cafasso, and L. Burris, "Chemical Engineering Division Reactor Safety and Physical Properties Studies Annual Report, July 1973 - June 1974," ANL-8120, p. 60.

10. D. W. Green, private communication (April 1980). 
A 1.1 .5 .9

$12 / 80$

URANIUM DIOXIDE

References (Cont'd)

11. D. W. Green and L. Leibowitz, "Vapor Pressures and Compositions over Hypostoichiometric Uranium Dioxide at High Temperature," ANL-CEN-RSD$81-1$ (1981).

12. D. L. Booth, "The Thermodynamic Properties of $\mathrm{UO}_{2}$ and Sodium," TRG Report $1871(\mathrm{R} / \mathrm{X})(1969)$.

13. D. C. Menzies, "The Equation of State of Uranium Dioxide at High Temperatures and Pressures", UKAEA Report TRG-1119 (D) (1966).

14. M. J. Gillan, "Thermodynamics of Nuclear Materials 1974", Vol. I, p. 269, International Atomic Energy Agency, Vienna (1975).

15. W. Breitung, "Calculation of Vapor Pressures of Oxide Fuels up to $5000 \mathrm{~K}$ for Equilibrium and Nonequilibrium Evaporation", KFK2091, (1975).

16. International Working Group on Fast Reactors "Summary Report, Specialists Meeting on Equations of State of Materials of Relevance to the Analysis of Hypothetical Fast Breeder Reactor Accidents", Harwe11, June 19-23, 1978, IWGFR/26.

17. J. F. Babelot, G. D. Brumme, P. R. Kinsman, and R. W. Ohse, "Vapor Pressure Measurements over Liquid $\mathrm{UO}_{2}$ and $(\mathrm{U}, \mathrm{Pu}) \mathrm{O}_{2}$ by Laser Surface Heating up to $5000 \mathrm{~K}$." Reaktortagung DATF, Mannheim, 351 (1977).

18. M. Bober, H. A. Karow, and K. Schretzmann, Evaporation Experiments to Determine the Vapor Pressure of UO 2 Fuel (3000-5000 K), Proc. IAEA Symp. on Thermodynamics of Nuclear Materials 1974, Vol. 1, p. 295, Vienna (1975). 
19. M. Bober, W. Breitung, H. A. Karow, H. Kleykamp, G. Schumacher, K. Thurnay, "Investigations of Thermodynamic Data of State of Fast Reactor Care Materials for Hypothetical Accident Analysis," paper presented at IWGFR Meeting on Equations of State of Materials of Relevance to the Analysis of Hypothetical Fast Breeder Reactor Accidents, A.E.R.E., Harwe11, U.K. (June 19-23, 1978).

20. M. Bober, W. Breitung, H. A. Karow, and K. Schretzmann, KFK 2364 (1976).

21. P. Browning, M. T. Gillan, P. E. Potter, and M. H. Rand, The Equation of State of Urania, paper presented at IWFGR Meeting on Equations of State of Materials of Relevance to the Analysis of Hypothetical Fast Breeder Reactor Accidents, A.E.R.E, Harwell, U.K. (June 19-23, 1978).

22. A. Pattoret and 0 . Pesme, Pressure-Temperature $(\mathrm{P}-\mathrm{T})$ data for $\mathrm{UO}_{2}$, paper presented at IWFGR Meeting on Equations of State of Materials of Relevance to the Analysis of Hypothetical Fast Breeder Reactor Accidents, A.E.R.E., Harwe11, U.K. (June 19-23, 1978). 
A 1.1 .6 .1

$12 / 80$

URANIUM DIOXIDE

$\mathrm{T}_{\mathrm{B}}$

\section{Boiling Point}

$3660 \pm 20 \mathrm{~K}$

The boiling point was calculated from the equation ${ }^{1}$ proposed by the International Working Group on Fast Reactors for the vapor pressure of liquid $\mathrm{UO}_{2}$ :

$$
\log P=28.65-34930 / T-5.64 \log \mathrm{T}
$$

where $P$ is in MPa and $T$ is in kelvins. The temperature corresponding to 1 atm ( $0.1013 \mathrm{MPa}$ ) was calculated to be $3660 \mathrm{~K}$ with a standard deviation of $5.5 \%$. 
A 1.1 .6 .2

$12 / 80$

URANIUM DIOXIDE

$\mathrm{T}_{\mathrm{B}}$

$\underline{\text { References }}$

1. International Working Group on Fast Reactors, "Summary Report, Spectalists Meeting on Equations of State of Materials of Relevance to the Analysis of Hypothetical Fast Breeder Reactor Accidents," Harwe11, June 19-23, 1978, IWGFR/26. 
A 1.1 .7 .1

$12 / 80$

URANIUM DIOXIDE

$\Delta \mathrm{H}_{\mathrm{g}}$

Heat of Vaporization

\begin{tabular}{|c|c|}
\hline $\mathrm{T}, \mathrm{K}$ & $\Delta \mathrm{H}_{\mathrm{g}}, \mathrm{kJ} \mathrm{mol}^{-1}$ \\
\hline 3120 & 522 \\
\hline 3200 & 519 \\
\hline 3300 & 514 \\
\hline 3400 & 509 \\
\hline 3500 & 505 \\
\hline 3600 & 500 \\
\hline 3700 & 495 \\
\hline 3800 & 490 \\
\hline 3900 & 486 \\
\hline 4000 & 481 \\
\hline 4100 & 476 \\
\hline 4200 & 472 \\
\hline 4300 & 467 \\
\hline 4400 & 462 \\
\hline 4500 & 458 \\
\hline 4600 & 453 \\
\hline 4700 & 448 \\
\hline 4800 & 444 \\
\hline 4900 & 439 \\
\hline 5000 & 434 \\
\hline 5100 & $(430) *$ \\
\hline 5200 & $(425)$ \\
\hline 5300 & $(420)$ \\
\hline 5400 & $(416)$ \\
\hline 5500 & (411) \\
\hline 5600 & (406) \\
\hline 5700 & (401) \\
\hline 5800 & $(397)$ \\
\hline 5900 & (392) \\
\hline 6000 & $(387)$ \\
\hline
\end{tabular}

* Extrapolated beyond range of Eq. (1). 
Heat of Vaporization

\begin{tabular}{ccc}
$\mathrm{T}, \mathrm{K}$ & $\Delta \mathrm{H}_{\mathrm{g}}$ & $\begin{array}{c}\text { Error } \\
\sigma \%\end{array}$ \\
\hline $3120-4000$ & & 5 \\
$4000-5000$ & $\mathrm{RT}^{2} \frac{\mathrm{d} \ln \mathrm{P}}{\mathrm{dT}}$ & 20 \\
$5000-6000$ & & 85
\end{tabular}


A 1.1 .7 .3

$12 / 80$

URANIUM DIOXIDE

Heat of Vaporization

The heat of vaporization was calculated by application of the Clausius-Clapeyron equation:

$$
\frac{\mathrm{d} \ln \mathrm{P}}{\mathrm{dT}}=\frac{\Delta \mathrm{H}_{\mathrm{g}}}{\mathrm{RT} \mathrm{T}^{2}}
$$

to the equation for the total vapor pressure over liquid $\mathrm{UO}_{2}$ :

$$
\log P=28.65-34930 / T-5.64 \log T
$$

In Eq. (2) $P$ is in MPa and $T$ is in kelvins. The value obtained at $3660 \mathrm{~K}$ (the calculated boiling point of liquid $\mathrm{UO}_{2}$ ) was $497 \mathrm{~kJ} / \mathrm{mole}$. Tabulated values over the temperature range of interest are given in the preceding table.

The estimated error $(1 \sigma)$ in the calculation of the heat of vaporization using the Clausius-Clapeyron equation and Eq. (2) for the vapor pressure has been calculated based on the error in the vapor pressure. The standard deviation in the temperature range 3120 to $4000 \mathrm{~K}$ is only $5 \%$ but increases to $20 \%$ in the temperature range 4000 to $5000 \mathrm{~K}$ and to $85 \%$ above $5000 \mathrm{~K}$. 
A 1.1 .7 .4

$12 / 80$

URANIUM DIOXIDE

$\Delta \mathrm{H}_{\mathrm{g}}$

\section{References}

1. International Working Group on Fast Reactors, "Summary Report, Specialists Meeting on Equations of State of Materials of Relevance to the Analysis of Hypothetical Fast Breeder Reactor Accidents," Harwe11, June 19-23, 1978, IWGFR/26. 


\section{Surface Tension}

$\mathrm{T}, \mathrm{K}$
$\sim 3120$

$\sigma, \mathrm{N} / \mathrm{m}$

0.494
Error $\mathrm{s}, \%$

15 
A 1.1 .8 .2

$12 / 80$

URANIUM DIOXIDE

$\sigma$

\section{Surface Tension}

$.494 \pm .074 \mathrm{~N} / \mathrm{m}$

The surface tension of solid UO 2 has been measured or calculated for a range of temperatures. Matzke, Inoue, and Warren ${ }^{1}$ have tabulated the available data. Because of large scatter in the data, no temperature correlation of the data has been made and no values are recommended.

Recent measurements of the surface tension of solid $\mathrm{UO}_{2}$ by Matzke, Inoue, and Warren ${ }^{1}$ at room temperature using an Hertzian indextation fracture method show a sensitivity to $0 / \mathrm{m}$ ratio. Their results range from $1.65 \mathrm{~N} / \mathrm{m}$ for $\mathrm{UO}_{1.989}$ and $1.8 \mathrm{~N} / \mathrm{m}$ for $\mathrm{UO}_{2}$ to $2.20 \mathrm{~N} / \mathrm{m}$ for $\mathrm{UO}_{2} .052^{\circ}$ The table below shows the available data on the surface tension of $\mathrm{UO}_{2}$ at the melting point. The mean value of these data is $0.494 \mathrm{~N} / \mathrm{m}$. The error, $1 \sigma$, is estimated at $15 \%$. This value should be used in the neighborhood of the melting point of $\mathrm{UO}_{2}$.

Surface Tension of $\mathrm{UO}_{2}$ at the Melting Point

\begin{tabular}{|c|c|c|c|}
\hline Surface Tension & Method Determined & Experiments & Reference \\
\hline $0.445 \pm .210$ & droplet photographs & Christensen & 2 \\
\hline $0.550 \pm .210$ & droplet photographs & Christensen & 2 \\
\hline $0.441 \pm .035$ & $\begin{array}{l}\text { liquid meniscus shape } \\
\text { measurements }\end{array}$ & Bates & 3 \\
\hline 0.420 & shape of frozen menisci & Chasanov & 4 \\
\hline $0.615 \pm .180$ & liquid drop measurements & Schins & 5 \\
\hline \multicolumn{4}{|c|}{ Nikolopoulos and Schulz ${ }^{6}$ estimate the $t$} \\
\hline
\end{tabular}


A 1.1 .8 .3

$12 / 80$

$$
\frac{\mathrm{d} \sigma}{\mathrm{dT}}=-0.19 \times 10^{-3} \mathrm{~N} \cdot \mathrm{m}^{-1} \cdot \mathrm{K}^{-1}
$$

Using this temperature dependence, the surface tension may be estimated as a function of temperature in the temperature range 3120 to $3225 \mathrm{~K}$ from

$$
\sigma=0.494-0.19 \times 10^{-3}(\mathrm{~T}-3120)
$$

where $T$ is in kelvins and $\sigma$ is in $\mathrm{N} / \mathrm{m}$. 


\section{A 1.1 .8 .4}

$12 / 80$

\section{References}

1. H. Matzke, T. Inoue, and R. Warren, J. Nucl. Mat. 91, 205 (1980).

2. J. A. Christensen, BNWL-SA-584A (1966).

3. M. G. Chasanov, L. Leibowitz, and S. D. Gabelnick, J. Nucl. Mat. 49, 129 (1974).

4. J. L. Bates, C. E. McNeilly, and J. J. Rasmussen, Materials Science Research 5, 11 (1970).

5. H. Schins, J. Nucl. Mat. 78, 215 (1978).

6. P. Nikolopoulos and B. Schulz, J. Nuc1. Mat. $\underline{82}, 172$ (1979). 
A 1.1 .9 .1

$12 / 80$

URANIUM DIOXIDE

$\rho$

Density

\begin{tabular}{|c|c|}
\hline $\mathrm{T}, \mathrm{K}$ & $\rho \times 10^{-3}, \mathrm{~kg} \cdot \mathrm{m}^{-3}$ \\
\hline 298.15 & 10.97 \\
\hline 300 & 10.97 \\
\hline 400 & 10.94 \\
\hline 500 & 10.92 \\
\hline 600 & 10.89 \\
\hline 700 & 10.86 \\
\hline 800 & 10.83 \\
\hline 900 & 10.80 \\
\hline 1000 & 10.76 \\
\hline 1100 & 10.73 \\
\hline 1200 & 10.69 \\
\hline 1300 & 10.65 \\
\hline 1400 & 10.61 \\
\hline 1500 & 10.56 \\
\hline 1600 & 10.52 \\
\hline 1700 & 10.47 \\
\hline 1800 & 10.43 \\
\hline 1900 & 10.38 \\
\hline 2000 & 10.33 \\
\hline 2100 & 10.27 \\
\hline 2200 & 10.22 \\
\hline 2300 & 10.16 \\
\hline 2400 & 10.11 \\
\hline 2500 & 10.05 \\
\hline 2600 & 9.987 \\
\hline 2700 & 9.925 \\
\hline 2800 & 9.862 \\
\hline 2900 & 9.798 \\
\hline 3000 & 9.732 \\
\hline 3100 & 9.664 \\
\hline 3120 & 9.651 \\
\hline
\end{tabular}


A 1.1 .9 .2

$12 / 80$

URANIUM DIOXIDE

$\rho$

\section{Density}

\begin{tabular}{|c|c|}
\hline$\underline{T, K}$ & $\rho \times 10^{-3}, \mathrm{~kg} \cdot \mathrm{m}^{-3}$ \\
\hline 3120 & 8.739 \\
\hline 3200 & 8.667 \\
\hline 3300 & 8.577 \\
\hline 3400 & 8.487 \\
\hline 3500 & $(8.397)^{*}$ \\
\hline 3600 & $(8.307)$ \\
\hline 3700 & $(8.218)$ \\
\hline 3800 & $(8.128)$ \\
\hline 3900 & $(8.038)$ \\
\hline 4000 & $(7.948)$ \\
\hline 4100 & $(7.858)$ \\
\hline 4200 & $(7.768)$ \\
\hline 4300 & $(7.678)$ \\
\hline 4400 & $(7.589)$ \\
\hline 4500 & $(7.499)$ \\
\hline 4600 & $(7.409)$ \\
\hline 4700 & $(7.319)$ \\
\hline 4800 & $(7.229)$ \\
\hline 4900 & $(7.139)$ \\
\hline 5000 & $(7.049)$ \\
\hline 5100 & $(6.959)$ \\
\hline 5200 & $(6.870)$ \\
\hline 5300 & $(6.690)$ \\
\hline 5400 & $(6.690)$ \\
\hline 5500 & $(6.600)$ \\
\hline 5600 & $(6.510)$ \\
\hline 5700 & $(6.420)$ \\
\hline 5800 & $(6.330)$ \\
\hline 5900 & $(6.241)$ \\
\hline 6000 & $(6.151)$ \\
\hline
\end{tabular}

*Parentheses indicate extrapolation beyond the range of experimental data. 
A 1.1 .9 .3

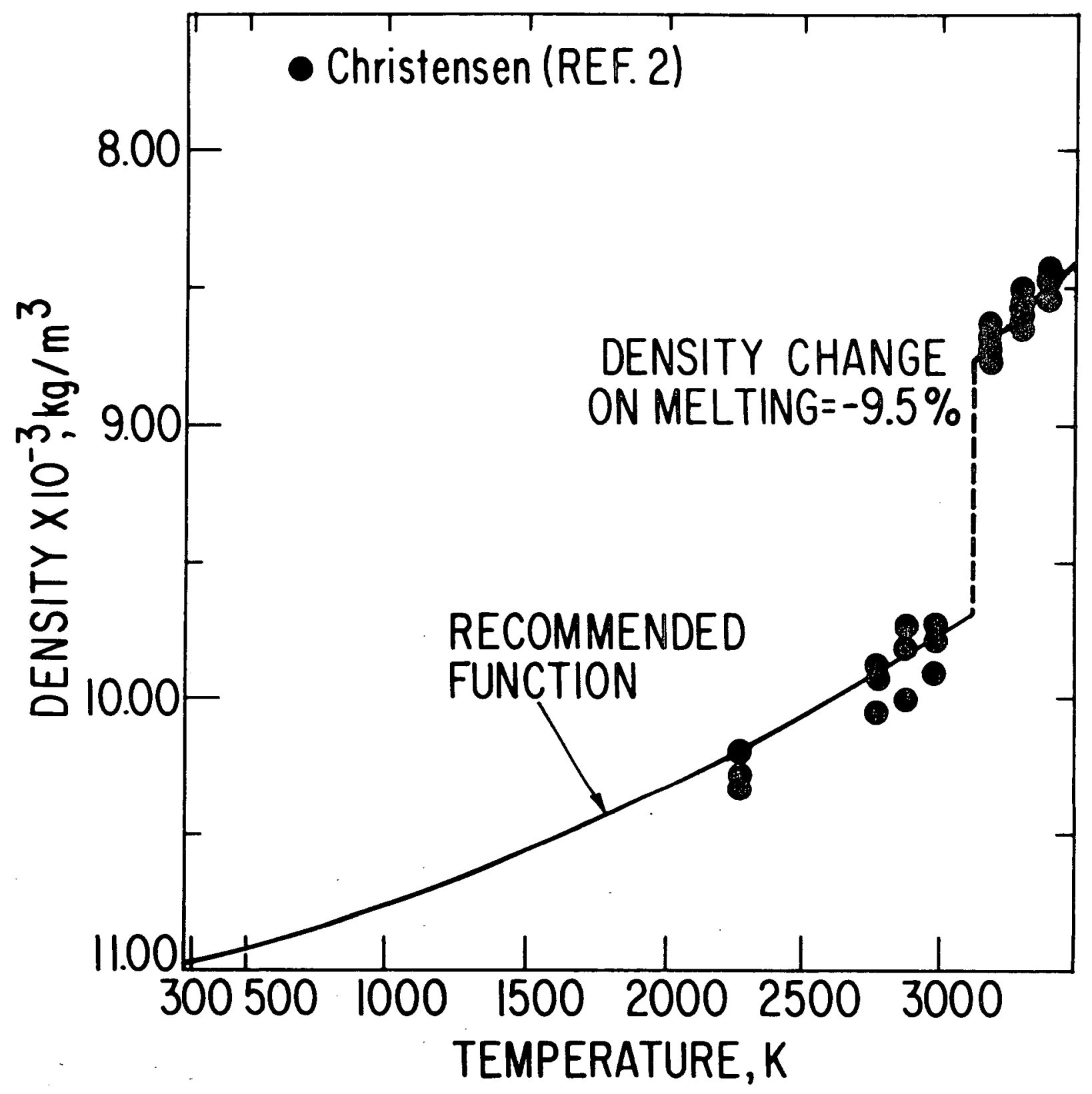

A comparison of the recommended function for the density of $\mathrm{UO}_{2}$ with experimental data. 
Density

\begin{tabular}{|c|c|c|c|}
\hline & $\mathrm{T}, \mathrm{K}$ & $\rho, \mathrm{kg} \cdot \mathrm{m}^{-3}$ & $\begin{array}{r}\text { Error } \\
\sigma, \%\end{array}$ \\
\hline 298 & -2000 (so1id) & $10970\left(1.0056-1.6324 \times 10^{-5} \mathrm{~T}-8.3281 \times 10^{-9} \mathrm{~T}^{2}\right.$ & 1 \\
\hline 2000 & -3120 (solid) & $\left.+2.0176 \times 10^{-13} \mathrm{~T}^{3}\right)$ & 2 \\
\hline 3120 & -3400 (1iquid) & & 9 \\
\hline 3400 & -4000 (1iquid) & $10970\left(1.0522-8.192 \times 10^{-5} \mathrm{~T}\right)$ & 13 \\
\hline 4000 & - 6000 (1iquid) & & 20 \\
\hline
\end{tabular}




\section{A 1.1 .9 .5}

\section{$\underline{\text { Density }}^{*}$}

O. D. Slagle $\mathrm{e}^{1}$ has analysed the $\mathrm{UO}_{2}$ thermal expansion data of Christensen ${ }^{2}$ in the temperature range 1550 to $3420 \mathrm{~K}$ and of Conway et al. ${ }^{3}$ from 1300 to $2500 \mathrm{~K}$. Using the analysis of $01 \mathrm{sen}^{4}$, Slagle recommends equations for the fractional change of length as a function of temperature. From these equations, he calculates the density of $\mathrm{UO}_{2}$ as a function of temperature and then fits these values to a polynomial.

The recommended equation for the density of solid $\mathrm{UO}_{2}$ is

$$
\begin{aligned}
\rho= & \rho_{0}\left(1.0056-1.6324 \times 10^{-5} \mathrm{~T}-8.3281 \times 10^{-9} \mathrm{~T}^{2}\right. \\
& +2.0176 \times 10^{-13} \mathrm{~T}^{3}
\end{aligned}
$$

where $\rho_{0}=10970 \mathrm{~kg} / \mathrm{m}^{3}$, the density of the solid at $298.15 \mathrm{~K}$. The density of liquid $\mathrm{UO}_{2}$ in the temperature range 3120 to $3420 \mathrm{~K}$ is given by

$$
\rho=\rho_{0}\left(1.0522-8.192 \times 10^{-5} \mathrm{~T}\right)
$$

where $\rho_{0}=10970 \mathrm{~kg} / \mathrm{m}^{3}$, the density of the solid at $298.15 \mathrm{~K}$. At the melting point, $3120 \mathrm{~K}$, the density of the solid given by Eq. (1) is $9660 \mathrm{~kg} / \mathrm{m}^{3}$. The density of the liquid at $3120 \mathrm{~K}$ is $8740 \mathrm{~kg} / \mathrm{m}^{3}$ from $\mathrm{Eq}$. (2). The density change at melting defined as $100\left(\rho_{\ell}^{-\rho_{s}}\right) / \rho_{s}$ is $-9.5 \%$. This is within experimental error of the experimental value of $-9.6 \%$ given by Christensen. 1

* The data analysis on which this section is based was contributed by 0 . D. Slagle, Hanford Engineering and Development Laboratory, Richland, WA. 
In the accompanying figure, the density functions as a function of temperature are compared with the high temperature density data for Christensen ${ }^{1}$ for single crystal $\mathrm{UO}_{2}$. The data agree with the functions to better than $\pm 2 \%$ at all temperatures in the range of comparison.

Above $3420 \mathrm{~K}$, we recommend using Eq. (2) for 1 iquid $\mathrm{UO}_{2} \cdot$ Comparisons have been made with the liquid densities of $\mathrm{UO}_{2}$ calculated via the law of rectilinear diameters from the vapor density of Green ${ }^{5}$ and from the vapor density derived from the IWGFR vapor pressure equation ${ }^{6}$ using the relative composition given by Green. ${ }^{5}$ In both cases, agreement between the extrapolation of Eq. (2) and the liquid densities calculated via the law of rectilinear diameters from the vapor densities was within $5 \%$ through $6000 \mathrm{~K}$.

Care must be taken in applying Eq. (1) above the sintering temperature of the sample. Since further densification can occur above the sintering temperature, Eq. (1) will not give accurate results unless the extent of densification is taken into account by adjusting $\rho_{0} \cdot$ Radiography of molten $\mathrm{UO}_{2}$ and ceramographic examinations of once molten $\mathrm{UO}_{2}$ samples indicate that the use of the theoretical density for $\rho_{0}$ may not always be valid. Thus, one has the option of adjusting $\rho_{0}$ for porosity in Eq. (2) when experimental data so indicates.

Insufficient data currently exist to evaluate how density is affected by oxygen stoichiometry and fission product accumulations during irradiation. The density is related to the experimental quantity fractional linear expansion by the following equations. The fractional change in density relative to the density $\rho_{0}$ at temperature $\mathrm{T}_{0}\left(\mathrm{~T}_{0}=298.15 \mathrm{~K}\right)$ is given by

$$
\frac{\Delta \rho}{\rho_{0}}=\frac{\rho-\rho_{0}}{\rho_{0}}
$$




\section{A 1.1 .9 .7}

Density at temperature $\mathrm{T}_{0}$ is

$$
\rho_{0}=\frac{m}{v_{0}}
$$

where $V_{0}$ is the volume at $T_{0}$ and $m$ is the sample mass. Thus, the density at temperature $\mathrm{T}$ is just

$$
\rho=\frac{m}{V}
$$

Since $V=V_{0}+\Delta V$

$$
\rho=\frac{m}{v_{0}\left(1+\frac{\Delta V}{V_{0}}\right)}
$$

Substituting Eq. (6) in Eq. (3), the fractional change in density in terms of the fraction change in volume is

$$
\frac{\Delta \rho}{\rho_{0}}=\frac{1-\left(1+\frac{\Delta V}{V_{0}}\right)}{\left(1+\frac{\Delta V}{V_{0}}\right)}
$$

The fractional change in volume is related to the fraction change in length by

$$
\frac{\Delta V}{V_{0}}=\left(1+\frac{\Delta L}{L_{0}}\right)^{3}-1
$$

Therefore,

$$
1+\frac{\Delta \mathrm{V}}{\mathrm{V}_{0}}=\left(1+\frac{\Delta \mathrm{L}}{\mathrm{L}_{0}}\right)^{3}
$$


Substituting Eq. (9) in Eq. (7) gives the fractional change in density in terms of the fractional change in length.

$$
\frac{\Delta \rho}{\rho_{0}}=\frac{1-\left(1+\frac{\Delta \mathrm{L}}{\mathrm{L}_{\mathrm{O}}}\right)^{3}}{\left(1+\frac{\Delta \mathrm{L}}{\mathrm{L}_{\mathrm{O}}}\right)}
$$

The fractional change in length relative to the length at $T_{0}(298.15 \mathrm{~K})$ is based on experimental data. For solid $\mathrm{UO}_{2}$ in the temperature range 298.15 to $3210 \mathrm{~K}$, the data is fit by

$$
\begin{aligned}
\frac{\Delta \mathrm{L}}{\mathrm{L}_{\mathrm{O}}}=- & 1.9305 \times 10^{-3}+5.723 \times 10^{-6} \mathrm{~T}+2.488 \times 10^{-9} \mathrm{~T}^{2} \\
& +1.140 \times 10^{-3} \mathrm{~T}^{3}
\end{aligned}
$$

For liquid $\mathrm{UO}_{2}$ in the temperature range 3120 to $3420 \mathrm{~K}$, the fractional change in length relative to the length of the solid at $298.15 \mathrm{~K}$ is

$$
\frac{\Delta L}{L_{0}}=7.87 \times 10^{-2}+3.775 \times 10^{-5}(T-3120)
$$

This equation for the change of length of liquid $\mathrm{UO}_{2}$ relative to the length of the solid takes into account the change in length of the solid from $298.15 \mathrm{~K}$ to the melting point $3120 \mathrm{~K}$, a linear expansion of 0.0436 , and the equivalent expansion at $3120 \mathrm{~K}$ due to melting which is 0.0351 . Thus, the total fractional change in length from a solid at $298.15 \mathrm{~K}$ to a liquid at $3120 \mathrm{~K}$ is 0.0787 . It is this factor that is multiplied by the mean thermal expansion coefficient, $3.5 \times 10^{-5}$, in the second term of $\mathrm{Eq} \cdot(12)$ to give $3.775 \times 10^{-5}$. Values from Eqs. (11) and (12) were fit by 0. D. Slagle ${ }^{1}$ to obtain the recommended equations for density [Eqs. (1) and (2)]. 


\section{A 1.1 .9 .9}

$12 / 80$

The estimated errors are those associated with the thermal expansion data and not with the polynomial fit to the calculated densities. The $R$ factor for both fits was greater than 0.9999999 ( $R=1$ is a perfect $f i t$ ) indicating that any error in fitting the density values is insignificant compared to the experimental error. For solid $\mathrm{vo}_{2}$, the recommended equation has an estimated uncertainty $\left(\begin{array}{ll}1 & \sigma\end{array}\right)$ of $\pm 1 \%$ to $2000 \mathrm{~K}$ and an uncertainty of $\pm 2 \%$ from $2000 \mathrm{~K}$ to the melting point $(3120 \mathrm{~K})$. The estimated error ( $1 \sigma$ ) for the equation for the density of molten $\mathrm{UO}_{2}$ is $\pm 9 \%$ from 3120 to $3420 \mathrm{~K}$. From 3420 to $4000 \mathrm{~K}$, the estimated error is $\pm 13 \%$; from 4000 to $6000 \mathrm{~K}$, the estimated error is $\pm 20 \%$. 

A 1.1 .9 .10

$12 / 80$

URANIUM DIOXIDE

$\rho$

\section{References}

1. 0. D. Slagle, private communication (December 1980).

2. J. A. Christensen, J. Amer. Cer. Soc. 40, 607 (1963).

3. J. B. Conway, R. M. Fincel, Jr., and R. A. Hein, "The Thermal Expansion and Heat Capacity of $\mathrm{UO}_{2}$ to $2200^{\circ} \mathrm{C}, "$ Trans. Am. Nuc1. Soc., 6, 153 (1963).

4. C. S. 01sen, "Fuel Thermal Expansion (FTHEXP)" in MATPRO - Version 11: A Handbook of Materials Properties for Use in the Analysis of Light Water Reactor Fuel Rod Behavior, edited by Donald L. Hagrman and Gregory A. Reymann, NUREG/CR-0497, TREE-1280 (February 1979).

5. D. W. Green, private communication (April 1980).

6. International Working Group on Fast Reactors "Summary Report, Specialists Meeting on Equations of State of Materials of Relevance to the Analysis of Hypothetical Fast Breeder Reactor Accidents", Harwe11, June 19-23, 1978, IWGFR/26. 
A 1.1 .10 .1

$12 / 80$

IRANIIJM DIOXIDE

Instantaneous Thermal Expansion Coefficient (Solid)

\begin{tabular}{|c|c|c|}
\hline $\mathrm{T}, \mathrm{K}$ & $\begin{array}{l}\quad \text { Linear } \\
\left(\alpha_{\mathrm{p}}\right)_{\ell} \times 10^{6}, \mathrm{~K}^{-1} \\
\end{array}$ & $\begin{array}{l}\text { Volumetric* } \\
\left(\alpha_{\mathrm{P}}\right) \times 10^{5}, \mathrm{~K}^{-1}\end{array}$ \\
\hline 298.15 & 7.24 & 2.171 \\
\hline 300 & 7.25 & 2.174 \\
\hline 400 & 7.76 & 2.329 \\
\hline 500 & 8.28 & 2.485 \\
\hline 600 & 8.81 & 2.643 \\
\hline 700 & 9.34 & 2.803 \\
\hline 800 & 9.88 & 2.964 \\
\hline 900 & 10.42 & 3.127 \\
\hline 1000 & 10.97 & 3.291 \\
\hline 1100 & 11.52 & 3.457 \\
\hline 1200 & 12.08 & 3.624 \\
\hline 1300 & 12.64 & 3.793 \\
\hline 1400 & 13.21 & 3.963 \\
\hline 1500 & 13.78 & 4.135 \\
\hline 1600 & 14.36 & 4.307 \\
\hline 1700 & 14.94 & 4.482 \\
\hline 1800 & 15.52 & 4.657 \\
\hline 1900 & 16.11 & 4.833 \\
\hline 2000 & 16.70 & 5.011 \\
\hline 2100 & 17.30 & 5.190 \\
\hline 2200 & 17.90 & 5.369 \\
\hline 2300 & 18.50 & 5.550 \\
\hline 2400 & 19.11 & 5.732 \\
\hline 2500 & 19.71 & 5.914 \\
\hline 2600 & 20.33 & 6.098 \\
\hline 2700 & 20.94 & 6.282 \\
\hline 2800 & 21.56 & 6.468 \\
\hline 2900 & 22.18 & 6.654 \\
\hline 3000 & 22.80 & 6.840 \\
\hline 3100 & 23.43 & 7.028 \\
\hline 3120 & 23.55 & 7.065 \\
\hline
\end{tabular}

* The recommended values in this column are not always precisely 3 times the values given in the preceeding column due to round-off to the number of justified significant figures. 
Instantaneous Thermal Expansion Coefficient (Liquid)

\begin{tabular}{|c|c|c|}
\hline $\mathrm{T}, \mathrm{K}$ & $\left(\alpha_{\mathrm{p}}\right)_{2} \begin{array}{l}\text { Linear } \\
\mathrm{N} 10^{5}\end{array}, \mathrm{~K}^{-1}$ & $\begin{array}{l}\text { Volumetric* } \\
\left(\alpha_{\mathrm{p}}\right) \times 10^{5}, \mathrm{~K}^{-1}\end{array}$ \\
\hline 3120 & 3.5 & 10.5 \\
\hline 3200 & 3.5 & 10.5 \\
\hline 3300 & 3.5 & 10.4 \\
\hline 3400 & 3.5 & 10.4 \\
\hline 3500 & $(3.5)^{+}$ & $(10.5)^{\dagger}$ \\
\hline 3600 & $(3.4)$ & $(10.3)$ \\
\hline 3700 & $(3.4)$ & $(10.3)$ \\
\hline 3800 & $(3.4)$ & $(10.4)$ \\
\hline 3900 & $(3.4)$ & $(10.2)$ \\
\hline 4000 & $(3.4)$ & $(10.2)$ \\
\hline 4100 & $(3.4)$ & $(10.2)$ \\
\hline 4200 & $(3.4)$ & $(10.1)$ \\
\hline 4300 & $(3.4)$ & $(10.1)$ \\
\hline 4400 & $(3.3)$ & $(10.0)$ \\
\hline 4500 & $(3.3)$ & $(10.0)$ \\
\hline 4600 & $(3.3)$ & $(10.0)$ \\
\hline 4700 & $(3.3)$ & $(9.9)$ \\
\hline 4800 & $(3 \cdot 3)$ & $(9.9)$ \\
\hline 4900 & $(3.3)$ & $(9.9)$ \\
\hline 5000 & $(3.3)$ & $(9.9)$ \\
\hline 5100 & $(3.3)$ & $(9.8)$ \\
\hline 5200 & $(3.3)$ & $(9.8)$ \\
\hline 5300 & $(3.3)$ & $(9.8)$ \\
\hline 5400 & $(3.2)$ & $(9.7)$ \\
\hline 5500 & $(3.2)$ & $(9.7)$ \\
\hline 5600 & $(3.2)$ & $(9.7)$ \\
\hline 5700 & $(3.2)$ & $(9.6)$ \\
\hline 5800 & $(3.2)$ & $(9.6)$ \\
\hline 5900 & $(3.2)$ & $(9.6)$ \\
\hline 6000 & $(3.2)$ & $(9.5)$ \\
\hline
\end{tabular}

* The recommended values in this column are not always precisely 3 times the values given in the preceding column due to round-off to the number of justified significant figures.

+ Parentheses indicate extrapolation beyond range of experimental data. 
A 1.1 .10 .3

$12 / 80$

URANIUM DIOXIDE

${ }^{\alpha} \mathrm{p}$

Mean Thermal Expansion Coefficient (Solid)

\begin{tabular}{|c|c|c|}
\hline $\mathrm{T}, \mathrm{K}$ & $\left(\bar{\alpha}_{\mathrm{P}}\right)_{\ell} \begin{array}{l}\text { Linear } \\
\mathrm{x} 10^{6}, \mathrm{~K}^{-1}\end{array}$ & $\begin{array}{l}\text { Volumetric } \\
\left(\bar{\alpha}_{\mathrm{P}}\right) \times 10^{5}, \mathrm{~K}^{-1}\end{array}$ \\
\hline 298.15 & 7.24 & 2.171 \\
\hline 300 & 7.24 & 2.17 .3 \\
\hline 400 & 7.50 & 2.252 \\
\hline 500 & 7.76 & 2.333 \\
\hline 600 & 8.03 & 2.415 \\
\hline 700 & 8.30 & 2.497 \\
\hline 800 & 8.57 & 2.581 \\
\hline 900 & 8.84 & 2.665 \\
\hline 1000 & 9.11 & 2.751 \\
\hline 1100 & 9.39 & 2.837 \\
\hline 1200 & 9.67 & 2.925 \\
\hline 1300 & 9.95 & 3.014 \\
\hline 1400 & 10.23 & 3.103 \\
\hline 1500 & 10.51 & 3.194 \\
\hline 1600 & 10.80 & 3.286 \\
\hline 1700 & 11.09 & 3.380 \\
\hline 1800 & 11.38 & 3.474 \\
\hline 1900 & 11.68 & 3.569 \\
\hline 2000 & 11.98 & 3.666 \\
\hline 2100 & 12.27 & 3.764 \\
\hline 2200 & 12.58 & 3.863 \\
\hline 2300 & 12.88 & 3.964 \\
\hline 2400 & 13.18 & 4.066 \\
\hline 2500 & 13.49 & 4.169 \\
\hline 2600 & 13.80 & 4.274 \\
\hline 2700 & 14.12 & 4.380 \\
\hline 2800 & 14.43 & 4.487 \\
\hline 2900 & 14.75 & 4.596 \\
\hline 3000 & 15.07 & 4.707 \\
\hline 3100 & 15.39 & 4.818 \\
\hline 3120 & 15.45 & 4.841 \\
\hline
\end{tabular}




\section{A 1.1 .10 .4}

$12 / 80$

URANIUM DIOXIDE

${ }^{\alpha} \mathrm{P}$

Mean Thermal Expansion Coefficient (Liquid)

\begin{tabular}{|c|c|c|}
\hline $\mathrm{T}, \mathrm{K}$ & $\left(\bar{\alpha}_{\mathrm{p}}\right)_{\ell} \begin{array}{l}\text { Linear } \\
\mathrm{N}\end{array}$ & $\begin{array}{l}\text { Volumetric } \\
\left(\bar{\alpha}_{\mathrm{P}}\right) \times 10^{5}, \mathrm{~K}^{-1} \\
\end{array}$ \\
\hline 3120 & 3.5 & 10.5 \\
\hline 3200 & 3.5 & 10.5 \\
\hline 3300 & 3.5 & 10.6 \\
\hline 3400 & $(3.5)^{*}$ & $(10.6)^{*}$ \\
\hline 3500 & $(3.5)$ & $(10.6)$ \\
\hline 3600 & $(3.5)$ & $(10.7)$ \\
\hline 3700 & $(3.5)$ & $(10.7)$ \\
\hline 3800 & $(3.5)$ & $(10.8)$ \\
\hline 3900 & $(3.5)$ & $(10.8)$ \\
\hline 4000 & $(3.5)$ & $(10.8)$ \\
\hline 4100 & $(3.5)$ & $(10.9)$ \\
\hline 4200 & $(3.5)$ & $(10.9)$ \\
\hline 4300 & $(3.5)$ & $(10.9)$ \\
\hline 4400 & $(3.5)$ & $(11.0)$ \\
\hline 4500 & $(3.5)$ & $(11.0)$ \\
\hline 4600 & $(3.5)$ & $(11.1)$ \\
\hline 4700 & $(3.5)$ & $(11.1)$ \\
\hline 4800 & $(3.5)$ & $(11.1)$ \\
\hline 4900 & $(3.5)$ & $(11.2)$ \\
\hline 5000 & $(3.5)$ & $(11.2)$ \\
\hline 5100 & $(3.5)$ & $(11.2)$ \\
\hline 5200 & $(3.5)$ & $(11.3)$ \\
\hline 5300 & $(3.5)$ & $(11.3)$ \\
\hline 5400 & $(3.5)$ & $(11.4)$ \\
\hline 5500 & $(3.5)$ & $(11.4)$ \\
\hline 5600 & $(3.5)$ & $(11.4)$ \\
\hline 5700 & $(3.5)$ & $(11.5)$ \\
\hline 5800 & $(3.5)$ & $(11.5)$ \\
\hline 5900 & $(3.5)$ & $(11.6)$ \\
\hline 6000 & $(3.5)$ & $(11.6)$ \\
\hline
\end{tabular}

* Parentheses indicate extrapolation beyond range of experimental data. 
A 1.1 .10 .5

$12 / 80$

URANIUM DIOXIDE

${ }^{\alpha} \mathbf{P}$

Fractional Thermal Expansion (Solid)

\begin{tabular}{|c|c|c|}
\hline $\mathrm{T}, \mathrm{K}$ & $\frac{\mathrm{L}-\mathrm{J}(298.15)}{\mathrm{L}(298.15)} \times 10^{2}$ & $\frac{V-V(298.15)}{V(298.15)} \times 10^{2}$ \\
\hline 298.15 & 0.0 & 0.0 \\
\hline 300 & 0.001 & 0.004 \\
\hline 400 & 0.076 & 0.229 \\
\hline 500 & 0.157 & 0.471 \\
\hline 600 & 0.242 & 0.729 \\
\hline 700 & 0.333 & 1.003 \\
\hline 800 & 0.430 & 1.295 \\
\hline 900 & 0.532 & 1.604 \\
\hline 1000 & 0.639 & 1.931 \\
\hline 1100 & 0.753 & 2.275 \\
\hline 1200 & 0.872 & 2.638 \\
\hline 1300 & 0.996 & 3.019 \\
\hline 1400 & 1.127 & 3.420 \\
\hline 1500 & 1.264 & 3.839 \\
\hline 1600 & 1.406 & 4.278 \\
\hline 1700 & 1.555 & 4.738 \\
\hline 1800 & 1.710 & 5.217 \\
\hline 1900 & 1.871 & 5.718 \\
\hline 2000 & 2.038 & 6.239 \\
\hline 2100 & 2.212 & 6.782 \\
\hline 2200 & 2.392 & 7.348 \\
\hline 2300 & 2.578 & 7.935 \\
\hline 2400 & 2.771 & 8.546 \\
\hline 2500 & 2.971 & 9.180 \\
\hline 2600 & 3.177 & 9.838 \\
\hline 2700 & 3.390 & 10.52 \\
\hline 2800 & 3.610 & 11.23 \\
\hline 2900 & 3.837 & 11.96 \\
\hline 3000 & 4.071 & 12.72 \\
\hline 3100 & 4.312 & 13.50 \\
\hline 3120 & 4.361 & 13.66 \\
\hline
\end{tabular}


Fractional Thermal Expansion (Liquid)

\begin{tabular}{|c|c|c|}
\hline$\underline{T, K}$ & $\frac{\mathrm{L}-\mathrm{L}(298.15)}{\mathrm{L}(298.15)} \times 10^{2}$ & $\frac{V-V(298.15)}{V(298.15)} \times 10^{2}$ \\
\hline 3120 & 7.87 & 25.52 \\
\hline 3200 & 8.17 & 26.57 \\
\hline 3300 & 8.54 & 27.90 \\
\hline 3400 & 8.93 & 29.24 \\
\hline 3500 & $(9.30)^{*}$ & $(30.59)^{*}$ \\
\hline 3600 & $(9.68)$ & $(31.95)$ \\
\hline 3700 & $(10.06)$ & $(33.32)$ \\
\hline 3800 & $(10.44)$ & $(34.69)$ \\
\hline 3900 & $(10.81)$ & $(36.08)$ \\
\hline 4000 & $(11.19)$ & $(37.47)$ \\
\hline 4100 & $(11.57)$ & $(38.88)$ \\
\hline 4200 & $(11.95)$ & $(40.29)$ \\
\hline 4300 & $(12.32)$ & $(41.72)$ \\
\hline 4400 & $(12.72)$ & $(43.15)$ \\
\hline 4500 & $(13.08)$ & $(44.59)$ \\
\hline 4600 & $(13.46)$ & $(46.05)$ \\
\hline 4700 & $(13.83)$ & $(47.51)$ \\
\hline 4800 & $(14.21)$ & $(48.98)$ \\
\hline 4900 & $(14.59)$ & $(50.46)$ \\
\hline 5000 & $(14.97)$ & $(51.96)$ \\
\hline 5100 & $(15.34)$ & $(53.46)$ \\
\hline 5200 & $(15.72)$ & $(54.97)$ \\
\hline 5300 & $(16.10)$ & $(56.49)$ \\
\hline 5400 & $(16.48)$ & $(58.02)$ \\
\hline 5500 & $(16.85)$ & $(59.56)$ \\
\hline 5600 & $(17.23)$ & $(61.12)$ \\
\hline 5700 & $(17.61)$ & $(62.68)$ \\
\hline 5800 & $(17.99)$ & $(64.25)$ \\
\hline 5900 & $(18.36)$ & $(65.83)$ \\
\hline 6000 & $(18.74)$ & $(67.42)$ \\
\hline
\end{tabular}

* Parentheses indicate extrapolation beyond range of experimental data. 
Fractional Thermal Expansion (Liquid)

\begin{tabular}{|c|c|c|}
\hline $\mathrm{T}, \mathrm{K}$ & $\frac{L-L(3120)}{L(3120)} \times 10^{2}$ & $\frac{V-V(3120)}{V(3120)} \times 10^{2}$ \\
\hline 3120 & 0.0 & 0.0 \\
\hline 3200 & 0.28 & 0.84 \\
\hline 3300 & 0.63 & 1.90 \\
\hline 3400 & 0.98 & 2.97 \\
\hline 3500 & $(1.33)^{*}$ & $(4.04)^{*}$ \\
\hline 3600 & $(1.68)$ & $(5.13)$ \\
\hline 3700 & $(2.03)$ & $(6.21)$ \\
\hline 3800 & $(2.38)$ & $(7.31)$ \\
\hline 3900 & $(2.73)$ & $(8.42)$ \\
\hline 4000 & $(3.08)$ & $(9.53)$ \\
\hline 4100 & $(3.43)$ & $(10.65)$ \\
\hline 4200 & $(3.78)$ & $(11.77)$ \\
\hline 4300 & $(4.13)$ & $(12.91)$ \\
\hline 4400 & $(4.48)$ & $(14.05)$ \\
\hline 4500 & $(4.83)$ & $(15.20)$ \\
\hline 4600 & $(5.18)$ & $(16.36)$ \\
\hline 4700 & $(5.53)$ & $(17.52)$ \\
\hline 4800 & $(5.88)$ & $(18.70)$ \\
\hline 4900 & $(6.23)$ & $(19.88)$ \\
\hline 5000 & $(6.58)$ & $(21.07)$ \\
\hline 5100 & $(6.93)$ & $(22.26)$ \\
\hline 5200 & $(7.28)$ & $(23.47)$ \\
\hline 5300 & $(7.63)$ & $(24.68)$ \\
\hline 5400 & $(7.98)$ & $(25.90)$ \\
\hline 5500 & $(8.33)$ & $(27.13)$ \\
\hline 5600 & $(8.68)$ & $(28.37)$ \\
\hline 5700 & $(9.03)$ & $(29.61)$ \\
\hline 5800 & $(9.38)$ & $(30.86)$ \\
\hline 5900 & $(9.73)$ & $(32.12)$ \\
\hline 6000 & $(10.08)$ & $(33.39)$ \\
\hline
\end{tabular}

* Parentheses indicate extrapolation beyond range of experimental data. 
A 1.1 .10 .8

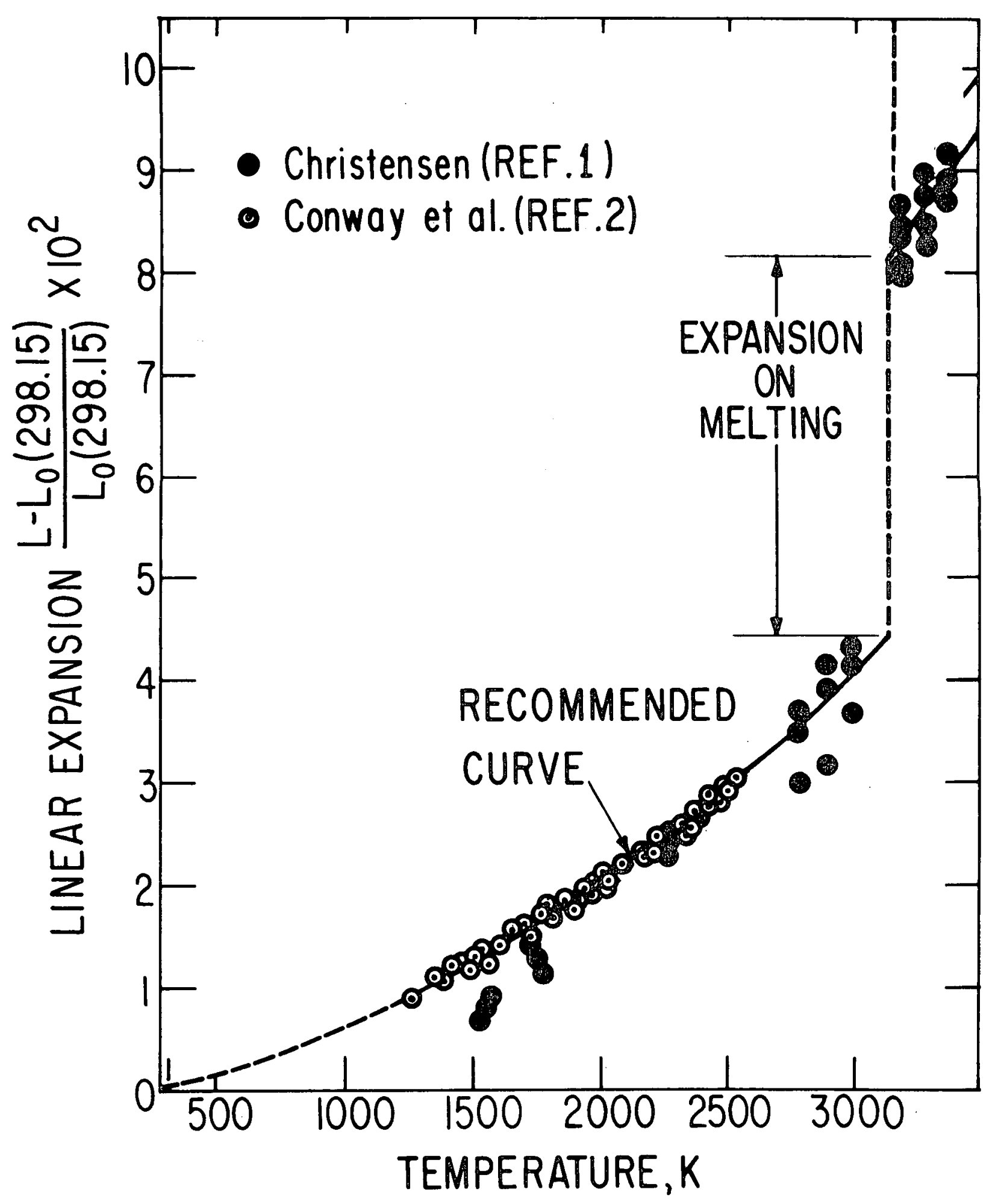

A comparison of the recommended function for the thermal expansion of $\mathrm{UO}_{2}$ with experimental data. 
Volumetric Instantaneous Thermal Expansion Coefficient

$\mathrm{T}, \mathrm{K} \quad \alpha_{\mathrm{P}}, \mathrm{K}^{-1}$

$$
\left.\begin{array}{r}
298-2000 \text { (solid) } \\
2000-3120 \text { (solid) }
\end{array}\right\}
$$$$
\frac{1.7169 \times 10^{-5}+1.4928 \times 10^{8} \mathrm{~T}+1.0260 \times 10^{-12} \mathrm{~T}^{2}}{0.9980695+5.723 \times 10^{-6} \mathrm{~T}+2.488 \times 10^{-9} \mathrm{~T}^{2}+1.140 \times 10^{-13} \mathrm{~T}^{3}}
$$$$
\left\{\begin{array}{l}
1 \\
2
\end{array}\right.
$$$$
\frac{1.05 \times 10^{-4}}{1+3.5 \times 10^{-5}(\mathrm{~T}-3120)}
$$$$
\left\{\begin{array}{c}
9 \\
13 \\
20
\end{array}\right.
$$ 


\section{Thermal Expansion Coefficient ${ }^{*}$}

Thermal expansion measurements have been made in the temperature range 1470 to $3420 \mathrm{~K}$ by Christensen ${ }^{1}$ and in the range 1300 to $2500 \mathrm{~K}$ by Conway et a1. ${ }^{2}$ Recent measurements of the thermal expansion of liquid $\mathrm{UO}_{2}$ by Drotning ${ }^{3}$ agree reasonably well with the results of Christensen. Drotning's preliminary results for the density at the melting point are $4 \%$ higher than the value reported by Christensen and his coefficient of volumetric thermal expansion for molten $\mathrm{UO}_{2}$ is $10 \%$ larger than Christensen's. The recommended equations for thermal expansion of $\mathrm{UO}_{2}$ derived by $\mathrm{O} . \mathrm{D}$. slagle ${ }^{4}$ are based on the analysis of solid $\mathrm{UO}_{2}$ by olsen ${ }^{5}$ and on the experimental results of Christensen ${ }^{1}$ for liquid $\mathrm{UO}_{2}$ :

For solid $\mathrm{UO}_{2}$, the recommended equation which is derived from experimental data is for fractional change in length $\left(\Delta L / L_{0}\right)$ and is

$$
\begin{aligned}
\frac{\Delta L}{L_{0}}= & -1.9305 \times 10^{-3}+5.723 \times 10^{-6} \mathrm{~T} \\
& +2.488 \times 10^{-9} \mathrm{~T}^{2}+1.140 \times 10^{-13} \mathrm{~T}^{3}
\end{aligned}
$$

where $\mathrm{L}_{0}$ is the length of the sample at $298.15 \mathrm{~K}$, $\mathrm{L}$ is the length at $\mathrm{T}$ (in kelvins), and $\Delta=\mathrm{L}-\mathrm{L}_{0}$. Equation (1) differs from that given by 0lsen, 4 in that Slagle has normalized the 0lsen expression to give $\frac{\Delta L}{L_{0}}=0$ at $298.15 \mathrm{~K}$. The mean linear thermal expansion coefficient is defined as

$$
\left(\bar{\alpha}_{\mathrm{P}}\right)_{\ell}=\frac{1}{\mathrm{~L}_{0}}\left(\frac{\mathrm{L}-\mathrm{L}_{0}}{\mathrm{~T}-\mathrm{T}_{0}}\right) .
$$

* The data analysis on which this section is based was contributed by o. D. Slagle, Hanford Engineering \& Development Laboratory, Richland, WA. 
As a function of ( $T-298.15)$, the mean linear thermal expansion coefficient for solid $\mathrm{UO}_{2}$ in units $1 / \mathrm{K}$ is

$$
\begin{aligned}
\left(\bar{\alpha}_{\mathrm{P}}\right)_{\ell}= & 7.237 \times 10^{-6}+2.590 \times 10^{-9}(\mathrm{~T}-298.15) \\
& +1.140 \times 10^{-13}(\mathrm{~T}-298.15)^{2} .
\end{aligned}
$$

From Eq. (2), it is clear that Eq. (1) is simply given by

$$
\frac{\Delta L}{L_{0}}=\left(\vec{\alpha}_{P}\right)_{\ell}(T-298.15)
$$

The instantaneous linear thermal expansion coefficient is defined as

$$
\left(\alpha_{P}\right)_{\ell}=\frac{1}{L}\left(\frac{\partial L}{\partial T}\right)_{P}
$$

The instantaneous linear thermal expansion coefficient is related to the mean linear thermal expansion coefficient $\left(\bar{\alpha}_{\mathrm{p}}\right)_{\ell}$ by

$$
\left(\alpha_{P}\right)_{\ell}=\frac{\frac{d\left(\bar{\alpha}_{P}\right)_{\ell}}{d T}\left(T-T_{0}\right)+\left(\bar{\alpha}_{P}\right)_{\ell}}{1+\left(\bar{\alpha}_{P}\right)_{\ell}\left(T-T_{0}\right)}
$$

where $\left(\alpha_{p}\right)_{\ell}$ is in $1 / K$.

In terms of the fractional change in length given in Eq. (1), the instantaneous linear thermal expansion coefficient is

$$
\left(\alpha_{\mathrm{P}}\right)_{\ell}=\frac{\frac{\mathrm{d}}{\mathrm{dT}}\left(\frac{\Delta \mathrm{L}}{\mathrm{L}_{\mathrm{O}}}\right)}{\left(1+\frac{\Delta \mathrm{L}}{\mathrm{L}_{\mathrm{O}}}\right)}
$$

which expressed in terms of temperature is

$$
\left(\alpha_{\mathrm{P}}\right)_{\ell}=\frac{5.723 \times 10^{-6}+4.976 \times 10^{-9} \mathrm{~T}+3.420 \times 10^{-13} \mathrm{~T}^{2}}{0.9980695+5.723 \times 10^{-6} \mathrm{~T}+2.487 \times 10^{-9} \mathrm{~T}^{2}+1.140 \times 10^{-13} \mathrm{~T}^{3}}
$$




\section{A 1.1 .10 .12}

The volumetric thermal expansion coefficients are related to the linear ones through the relation of the linear and volumetric fractional change with temperature. The volumetric fractional change with temperature from volume $V_{0}$ at temperature $T_{0}$ to volume $V$ at temperature $T$ is given by

$$
\frac{\Delta \mathrm{V}}{\mathrm{V}_{\mathrm{O}}}=\frac{\mathrm{V}-\mathrm{VO}}{\mathrm{V}_{\mathrm{O}}}=\frac{\left(\mathrm{L}_{\mathrm{O}}+\Delta \mathrm{L}\right)^{3}-\mathrm{L}_{0}^{3}}{\mathrm{~L}_{0}{ }^{3}}
$$

and

$$
\begin{aligned}
\frac{\Delta \mathrm{V}}{\mathrm{V}_{\mathrm{O}}} & =\left(1+\frac{\Delta \mathrm{L}}{\mathrm{L}_{\mathrm{O}}}\right)^{3}-1 \\
& =3\left(\frac{\Delta \mathrm{L}}{\mathrm{L}_{\mathrm{O}}}\right)+3\left(\frac{\Delta \mathrm{L}}{\mathrm{L}_{\mathrm{O}}}\right)^{2}+\left(\frac{\Delta \mathrm{L}}{\mathrm{L}_{\mathrm{O}}}\right)^{3} .
\end{aligned}
$$

Using Eq. (1) for $\Delta \mathrm{L} / \mathrm{L}_{\mathrm{O}}$ in $\mathrm{Eq} \cdot(9)$, the fractional change in volume with temperature is

$$
\begin{aligned}
\frac{\Delta V}{V_{0}}= & \left(0.9980695+5.723 \times 10^{-6} \mathrm{~T}+2.488 \times 10^{-9} \mathrm{~T}^{2}\right. \\
& \left.+1.140 \times 10^{-13} \mathrm{~T}^{3}\right)^{3}-1
\end{aligned}
$$

where $V_{0}$ is the volume at $298.15 \mathrm{~K}$.

The mean volumetric thermal expansion coefficient is defined as

$$
a_{P}=\frac{1}{v_{0}}\left(\frac{v-v_{0}}{T-T_{0}}\right)
$$

In terms of the linear fractional change, the mean volumetric thermal expansion coefficient is 


$$
\bar{\alpha}_{\mathrm{P}}=\frac{1}{\mathrm{~T}-\mathrm{T}_{\mathrm{O}}}\left[\left(1+\frac{\Delta \mathrm{L}}{\mathrm{L}_{\mathrm{O}}}\right)^{3}-1\right]
$$

which may be written as

$$
\bar{\alpha}_{\mathrm{P}}=\frac{1}{\mathrm{~T}-\mathrm{T}_{\mathrm{O}}}\left[3\left(\frac{\Delta \mathrm{L}}{\mathrm{L}_{\mathrm{O}}}\right)+3\left(\frac{\Delta \mathrm{L}}{\mathrm{L}_{\mathrm{O}}}\right)^{2}+\left(\frac{\Delta \mathrm{L}}{\mathrm{L}_{\mathrm{O}}}\right)^{3}\right] \text {. }
$$

The mean volumetric thermal expansion coefficient is related to the mean linear thermal expansion coefficient by the equation

$$
\bar{\alpha}_{\mathrm{p}}=3\left(\bar{\alpha}_{\mathrm{P}}\right)_{\ell}+3\left(\mathrm{~T}-\mathrm{T}_{0}\right)\left(\bar{\alpha}_{\mathrm{P}}\right)_{\ell}^{2}+\left(\mathrm{T}-\mathrm{T}_{0}\right)^{2}\left(\bar{\alpha}_{\mathrm{P}}\right)_{\ell}^{3} .
$$

The instantaneous volumetric thermal expansion coefficient defined as

$$
\alpha_{p}=\frac{1}{V}\left(\frac{\partial V}{\partial T}\right)_{P}
$$

is the thermal expansion coefficient most commonly used in thermodynamic relations. It is related to the mean volumetric thermal expansion coefficient by the equation

$$
\alpha_{P}=\frac{\frac{d \bar{\alpha}_{P}}{d T}\left(T-T_{0}\right)+\bar{\alpha}_{P}}{1+\bar{\alpha}_{P}\left(T-T_{0}\right)}
$$

Using Eq. (14) in Eq. (18), the instantaneous volumetric thermal expansion coefficient may be expressed in terms of linear fractional change $\Delta^{L} / L_{0}$

$$
\alpha_{P}=\frac{3 \frac{d}{d T}\left(\frac{\Delta L}{L_{0}}\right)}{\left(1+\frac{\Delta L}{L_{0}}\right)}
$$




$$
\text { A } 1.1 .10 .14
$$

$12 / 80$

URANIUM DIOXIDE

$a_{p}$

which is three times the instantaneous linear thermal expansion coefficient,

$$
\alpha_{p}=3\left(\alpha_{p}\right)_{\ell}
$$

Using Eq. (8) in Eq. (20), the instantaneous volumetric thermal expansion coefficient of solid $\mathrm{UO}_{2}$ expressed as a function of temperature is

$$
\alpha_{P}=\frac{1.7169 \times 10^{-5}+1.4928 \times 10^{-8} \mathrm{~T}+1.0260 \times 10^{-12} \mathrm{~T}^{2}}{0.9980695+5.723 \times 10^{-6} \mathrm{~T}+2.488 \times 10^{-9} \mathrm{~T}^{2}+1.140 \times 10^{-13} \mathrm{~T}^{3}}
$$

From his analysis of Christensen' ${ }^{1}$ experimental data on the thermal expansion of liquid $\mathrm{UO}_{2}, 0$. D. Slagle ${ }^{4}$ recommends using $3.5 \times 10^{-5} \mathrm{~K}$ for the linear thermal expansion coefficient for liquid $\mathrm{UO}_{2}$. He expresses the fractional change in length relative to $\mathrm{L}_{0}$, the length of the solid at $298.15 \mathrm{~K}$ as

$$
\frac{\Delta \mathrm{L}}{\mathrm{L}_{\mathrm{O}}}=7.87 \times 10^{-2}+3.775 \times 10^{-5}(\mathrm{~T}-3120)
$$

The constant term, $7.87 \times 10^{-2}$, comes from the expansion of the solid from $298.15 \mathrm{~K}$ to the melting point $3120 \mathrm{~K}$ plus the fractional change on melting. The factor $3.775 \times 10^{-5}$ is the thermal expansion coefficient $3.5 \times 10^{-5}$ times 1.0787 , the length of the molten sample at $3120 \mathrm{~K}$. The fractional change of the liquid $\mathrm{UO}_{2}$ relative to the length of molten liquid $\mathrm{UO}_{2}$ at $3120 \mathrm{~K}$ is

$$
\frac{\Delta \mathrm{L}}{\mathrm{L}_{\mathrm{m}}}=3.5 \times 10^{-5}(\mathrm{~T}-3120)
$$

where $L_{m}$ is the length of the liquid at the melting point, $3120 \mathrm{~K}$. 
A 1.1 .10 .15

$12 / 80$

URANIUM DIOXIDE

${ }^{\alpha}$

Equation (22) is for a theoretically dense sample. If the material is not theoretically dense, upon melting there will be a densification due to the change in porosity. This effect may be accounted for in the fractional linear expansion relative to the solid at $298.15 \mathrm{~K}$ by the addition of the term:

$$
\left(\frac{\Delta \mathrm{L}}{\mathrm{L}_{0}}\right)_{\mathrm{X}}=-\left(1-\mathrm{X}^{1 / 3}\right)
$$

where $\mathrm{X}$ is the ratio of the sample density to the theoretical density.

The mean linear thermal expansion coefficient for liquid $\mathrm{UO}_{2}$ is

$$
\left(\alpha_{P}\right)_{\ell}=3.5 \times 10^{-5} \mathrm{~K}^{-1}
$$

The instantaneous linear thermal expansion coefficient defined as:

$$
\left(\alpha_{P}\right)_{\ell}=\frac{1}{L}\left(\frac{\partial L}{\partial T}\right)_{P}
$$

in terms of the mean linear thermal expansion coefficient is:

$$
\left(\alpha_{P}\right)_{\ell}=\frac{3.5 \times 10^{-5}}{1+3.5 \times 10^{-5}(T-3120)}
$$

for liquid $\mathrm{UO}_{2}$.

The fractional change in volume of liquid $\mathrm{UO}_{2}$ relative to the volume of solid $\mathrm{UO}_{2}$ at $298.15 \mathrm{~K}$,

is given by

$$
\frac{\Delta V}{V_{0}}=\frac{V-V_{0}}{V_{0}}
$$

$$
\frac{\Delta V}{V_{0}}=\left[1.0787+3.775 \times 10^{-5}(\mathrm{~T}-3120)\right]^{3}-1
$$


A 1.1 .10 .16

$12 / 80$

URANIUM DIOXIDE

$\alpha_{p}$

Equations (10) and (22) were used to obtain the above equation. The fractional change in volume of liquid $\mathrm{UO}_{2}$ relative to the volume of liquid $\mathrm{UO}_{2}$ at the melting point, $\mathrm{V}_{\mathrm{m}}$,

$$
\frac{\Delta V}{V_{m}}=\frac{V-V_{m}}{V_{m}}
$$

is given by

$$
\frac{\Delta V}{V_{m}}=\left[1+3.5 \times 10^{-5}(\mathrm{~T}-3120)\right]^{3}-1
$$

The mean volumetric thermal expansion coefficient of liquid $\mathrm{UO}_{2}$ is defined as

$$
\bar{\alpha}_{\mathrm{P}}=\frac{1}{\mathrm{~V}_{\mathrm{m}}}\left(\frac{\mathrm{V}-\mathrm{V}_{\mathrm{m}}}{\mathrm{T}-\mathrm{T}_{\mathrm{m}}}\right)
$$

where $\mathrm{V}=$ volume of the liquid at temperature $\mathrm{T}$,

$\mathrm{V}_{\mathrm{m}}=$ volume of the liquid at temperature $\mathrm{T}_{\mathrm{m}}$, and

$\mathrm{T}_{\mathrm{m}}=$ melting point of $\mathrm{UO}_{2}, 3120 \mathrm{~K}$.

Equation (16) relates the mean volumetric thermal expansion coefficient to the mean linear thermal expansion coefficient. Using Eq. (16) with $\mathrm{T}_{0}=\mathrm{T}_{\mathrm{m}}$ and Eq. (32), the mean volumetric thermal expansion coefficient of liquid $\mathrm{UO}_{2}$ is

$$
\bar{\alpha}_{\mathrm{p}}=1.05 \times 10^{-4}+3.675 \times 10^{-9}(\mathrm{~T}-3120)+4.2875 \times 10^{-4}(\mathrm{~T}-3120)^{2} .
$$

The instantaneous volumetric thermal expansion coefficient, defined

as

$$
\alpha_{P}=\frac{1}{V}\left(\frac{\partial V}{\partial T}\right)_{P}
$$


has been shown, Eq. (20) to be equal to three times the instantaneous linear thermal expansion coefficient. Thus, using Eqs. (20) and (27), the instantaneous volumetric thermal expansion coefficient of 1iquid $\mathrm{UO}_{2}$ is

$$
\alpha_{P}=\frac{1.05 \times 10^{-4}}{1+3.5 \times 10^{-5}(T-3120)}
$$

Equations (22) through (35) are for liquid $\mathrm{UO}_{2}$ in the temperature range 3120 to $3420 \mathrm{~K}$. Above $3420 \mathrm{~K}$, no experimental data exist. As an estimate, the recommended functions for the liquid range 3120 to $3420 \mathrm{~K}$ may be used but since this function is based only on a $300 \mathrm{~K}$ temperature range, large errors may be introduced.

In the above discussion, expressions are given for the linear fractional change with temperature, volumetric fractional change with temperature, and the linear and volumetric mean and instantaneous thermal expansion coefficients. Note that the frequently used factor of three to relate volumetric and linear thermal expansion coefficients or fractional changes holds only for instantaneous thermal expansion coefficients. In general, the relation for mean thermal expansion coefficients is more complicated and the factor of three is just the first term of a series. While the instantaneous volumetric thermal expansion coefficient is the significant thermodynamic quantity, it is usually the mean thermal expansion coefficient (either linear or volumetric) that is measured experimentally. The instantaneous thermal expansion coefficient is a differential quantity. It is related to the mean thermal expansion coefficient by 
A 1.1 .10 .18

$12 / 80$

URANIUM DIOXIDE

$\alpha_{\mathrm{P}}$

$\alpha=\frac{\frac{\mathrm{d} \bar{\alpha}}{\mathrm{dT}}\left(\mathrm{T}-\mathrm{T}_{0}\right)+\bar{\alpha}}{1+\bar{\alpha}\left(\mathrm{T}-\mathrm{T}_{0}\right)}$

where $\alpha=$ instantaneous thermal expansion coefficient

and $\bar{\alpha}=$ mean thermal expansion coefficient.

The following figure also illustrates their relation.

No data exist on the effects of $O / M$ and irradiation on the thermal expansion coefficients of solid or liquid $\mathrm{UO}_{2}$.

The thermal expansion data of Conway et al. ${ }^{2}$ vary about the fit by $\pm 2 \%(2 \sigma)$. Christensen's data ${ }^{1}$ have a reported uncertainty $(2 \sigma)$ of $\pm 13 \%$ for the solid and $\pm 18 \%$ for the liquid up to $3420 \mathrm{~K}$. The good agreement between the data of Conway et al. and that of Christensen in the solid region seems to indicate that Christensen's data in this region are better than he estimates. The estimated error $\left(\begin{array}{ll}1 & \sigma\end{array}\right)$ is $\pm 1 \%$ for the solid below $2000 \mathrm{~K}$ and $\pm 2 \%$ from $2000 \mathrm{~K}$ to the melting point $(3120 \mathrm{~K})$. For 1 iquid $\mathrm{UO}_{2}$ in the temperature range 3120 to $3400 \mathrm{~K}$, the estimated uncertainty $\left(\begin{array}{ll}1 & \sigma\end{array}\right)$ is $\pm 9 \%$. Above $3400 \mathrm{~K}$, we estimate the uncertainty to be $\pm 13 \%$ to $4000 \mathrm{~K}$ and $\pm 20 \%$ above $4000 \mathrm{~K}$. These values are consistent with the estimated uncertainties in the density in these temperature ranges. 
A $1.1 .10 .18 \mathrm{a}$

$(12 / 80)$

URANIUM DIOXIDE

$\alpha_{p}$

\section{Note Added In Proof}

The values of $\alpha_{\mathrm{P}}$ for liquid $\mathrm{UO}_{2}$ calculated from the definition

$$
\alpha_{P}=-\frac{1}{\rho}\left(\frac{\partial \rho}{\partial T}\right)_{P}
$$

where $\rho$ is replaced by the liquid density given by

$$
\rho=\rho_{0}\left[1.0522-8.192 \times 10^{-5} \mathrm{~T}\right]
$$

where $\rho_{0}=10970 \mathrm{~kg} / \mathrm{m}^{3}$

are not the same as the values calculated from

$$
\alpha_{P}=\frac{1}{V}\left(\frac{\partial V}{\partial T}\right)_{P}
$$

where $V=L^{3}$ and

$$
\frac{\Delta L}{L_{m}}=\left(\bar{\alpha}_{P}\right)_{\ell}\left(T-T_{m}\right)=3.5 \times 10^{-5}\left(T-T_{m}\right)
$$

The source of the difference is from the linearization of the density, i,e.,

$$
\begin{aligned}
& \rho=\frac{\rho_{\mathrm{m}}}{\left[1+\left(\overline{\left.\alpha_{\mathrm{p}}\right)_{\ell}}\left(\mathrm{T}-\mathrm{T}_{\mathrm{m}}\right)\right]^{3}\right.} \approx \rho_{\mathrm{m}}\left[1-3\left(\bar{\alpha}_{\mathrm{p}}\right)_{\ell}\left(\mathrm{T}-\mathrm{T}_{\mathrm{m}}\right)\right] \\
& =\rho_{0}\left[1.0522-8.192 \times 10^{-5} \mathrm{~T}\right]
\end{aligned}
$$

This approximation is only valid for $\left(\bar{\alpha}_{\mathrm{p}}\right)_{\ell}\left(\mathrm{T}-\mathrm{T}_{\mathrm{m}}\right)<<1$. At large $\mathrm{T}$ (around $6000 \mathrm{~K}),\left(\bar{\alpha}_{\mathrm{P}}\right)_{\ell}\left(\mathrm{T}-\mathrm{T}_{\mathrm{m}}\right)$ is of order 0.1 and the approximation is not valid. 


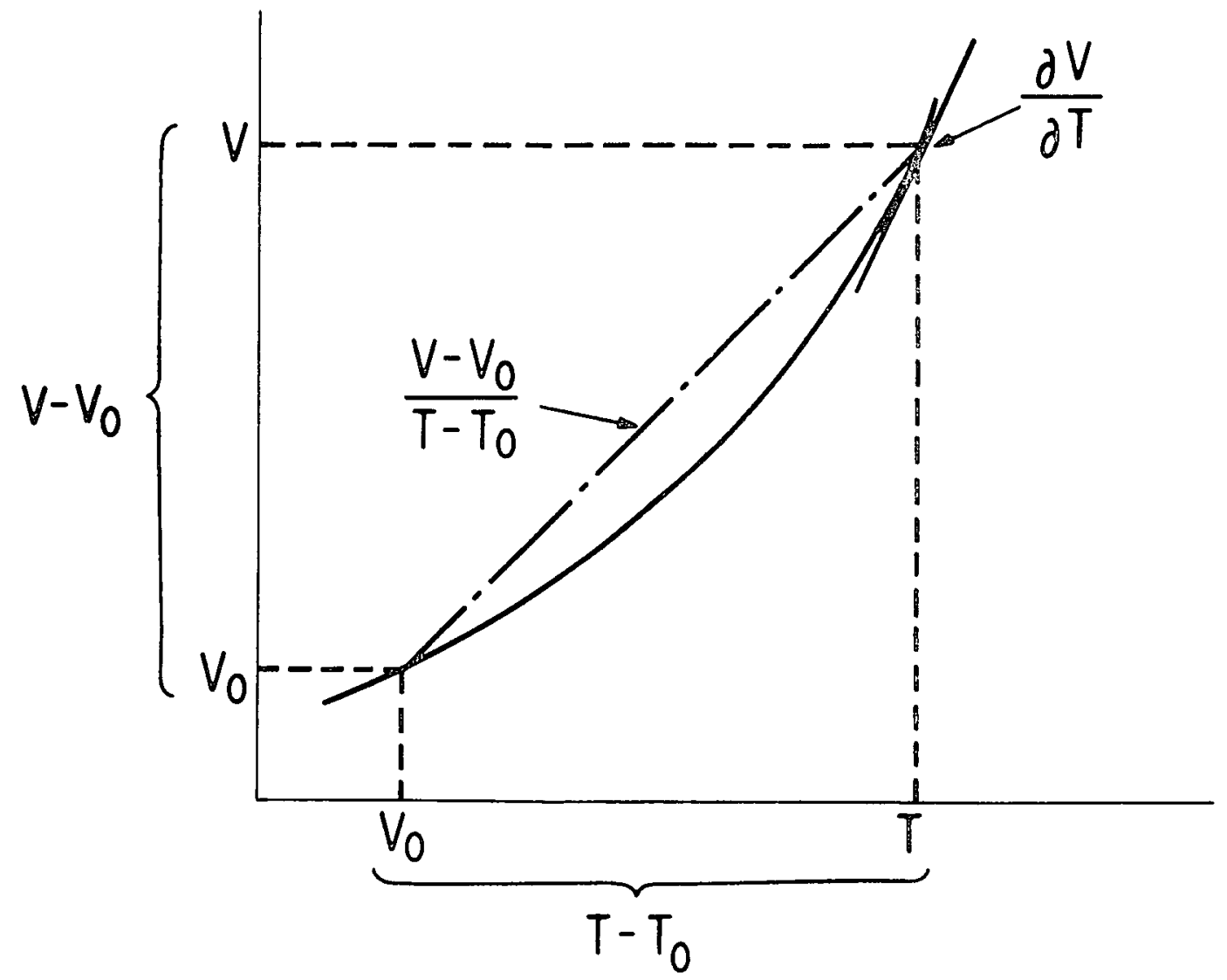

$$
\begin{aligned}
& \alpha_{P}=\frac{1}{V}\left(\frac{\partial V}{\partial T}\right)_{P} \\
& \overline{\alpha_{P}}=\frac{1}{V_{0}}\left(\frac{V-V_{0}}{T-T_{0}}\right)
\end{aligned}
$$

Relationship of instantaneous volumetric thermal expansion coefficient, ${ }^{\alpha} \mathrm{P}$, and mean volumetric thermal expansion coefficient, ${ }_{\mathrm{P}}$. 
A 1.1 .10 .20

$12 / 80$

URANIUM DIOXIDE

$\alpha_{\mathrm{P}}$

\section{$\underline{\text { References }}$}

1. J. A. Christensen, J. Am. Ceram. Soc., 40, 607 (1963).

2. J. B. Conway, R. M. Fencil, and R. A. Hein, Trans. Am. Nucl. Soc., 6, 153 (1963).

3. W. D. Drotning, private communication.

4. O. D. Slagle, private communication (December 1980).

5. C. S. Olsen "Fuel Therma1 Expansion (FTHEXP)" in MATPRO - Version 11: A Handbook of Materials Properties for Use in the Analysis of Light Water Reactor Fuel Rod Behavior, edited by Donald L. Hagrman and Gregory A. Reymann, NUREG/CR-0497, TREE-1280 (February 1979). 
A 1.1 .11 .2

$12 / 80$

URANIUM DIOXIDE

B $S$

Adiabatic Compressibility

\begin{tabular}{|c|c|c|}
\hline$T, K$ & ${ }^{B} \mathrm{~S}-10^{6}, \mathrm{MPa}^{-1}$ & ${ }^{B} \mathrm{~S} \times 10^{7}, \mathrm{~atm}^{-1}$ \\
\hline $3120(\ell)$ & 33.07 & 33.51 \\
\hline 3200 & $(35.07)^{*}$ & $(35.53)^{\star}$ \\
\hline 3300 & $(37.80)$ & $(38.30)$ \\
\hline 3400 & $(40.84)$ & $(41.38)$ \\
\hline 3500 & $(43.87)$ & $(44.45)$ \\
\hline 3600 & $(47.06)$ & $(47.68)$ \\
\hline 3700 & $(50.41)$ & $(51.08)$ \\
\hline 3800 & $(53.94)$ & $(54.66)$ \\
\hline 3900 & $(57.66)$ & $(58.43)$ \\
\hline 4000 & $(61.59)$ & $(62.41)$ \\
\hline 4100 & $(65.75)$ & $(66.62)$ \\
\hline 4200 & $(70.16)$ & $(71.09)$ \\
\hline 4300 & $(74.84)$ & $(75.83)$ \\
\hline 4400 & $(79.81)$ & $(80.87)$ \\
\hline 4500 & $(85.11)$ & $(86.24)$ \\
\hline 4600 & $(90.76)$ & $(91.97)$ \\
\hline 4700 & $(96.81)$ & $(98.10)$ \\
\hline 4800 & $(103.3)$ & $(104.7)$ \\
\hline 4900 & $(110.3)$ & $(111.7)$ \\
\hline 5000 & $(117.8)$ & $(119.4)$ \\
\hline 5100 & $(125.9)$ & $(127.6)$ \\
\hline 5200 & $(134.8)$ & $(136.6)$ \\
\hline 5300 & $(144.4)$ & $(146.3)$ \\
\hline 5400 & $(154.9)$ & $(156.9)$ \\
\hline 5500 & $(166.4)$ & $(168.6)$ \\
\hline 5600 & $(179.1)$ & $(181.4)$ \\
\hline 5700 & $(193.1)$ & $(195.7)$ \\
\hline 5800 & $(208.8)$ & $(211.5)$ \\
\hline 5900 & $(226.3)$ & $(229.3)$ \\
\hline 6000 & $(246.1)$ & $(249.3)$ \\
\hline
\end{tabular}

* Parentheses indicate extrapolation beyond the range of experimental data. 
A 1.1 .11 .1

$12 / 80$

URANIUM DIOXIDE

${ }_{\text {B }}$

Adiabatic Compressibility

$\begin{array}{lcc}\underline{\mathrm{T}, \mathrm{K}} & { }_{-\mathrm{S}} \times \mathrm{10}^{6}, \mathrm{MPa}^{-1} & \mathrm{~B}_{\mathrm{S}} \times 10^{7}, \mathrm{~atm}^{-1} \\ 298.15 & 4.899 & 4.964 \\ 300 & 4.900 & 4.965 \\ 400 & 4.956 & 5.022 \\ 500 & 5.014 & 5.178 \\ 600 & 5.072 & 5.140 \\ 700 & 5.133 & 5.201 \\ 800 & 5.194 & 5.263 \\ 900 & 5.258 & 5.327 \\ 1000 & 5.322 & 5.393 \\ 1100 & 5.389 & 5.460 \\ 1200 & 5.457 & 5.529 \\ 1300 & 5.527 & 5.600 \\ 1400 & 5.598 & 5.673 \\ 1500 & 5.672 & 5.747 \\ 1600 & 5.748 & 5.824\end{array}$


A 1.1 .11 .3

$12 / 80$

URANIUM DIOXIDE

Isotherma1 Compressibility

$\begin{array}{lcc}\underline{\mathrm{T}, \mathrm{K}} & \beta_{\mathrm{T}} \mathrm{x} \mathrm{10}^{6}, \mathrm{MPa}^{-1} & B_{\mathrm{T}} \mathrm{x} 10^{7}, \mathrm{~atm}^{-1} \\ 298.15 & 4.953 & 5.019 \\ 300 & 4.954 & 5.020 \\ 400 & 5.031 & 5.098 \\ 500 & 5.115 & 5.182 \\ 600 & 5.205 & 5.274 \\ 700 & 5.303 & 5.374 \\ 800 & 5.409 & 5.480 \\ 900 & 5.523 & 5.596 \\ 1000 & 5.645 & 5.720 \\ 1100 & 5.777 & 5.854 \\ 1200 & 5.918 & 5.997 \\ 1300 & 6.070 & 6.151 \\ 1400 & 6.233 & 6.316 \\ 1500 & 6.407 & 6.492 \\ 1600 & 5.748 & 6.678\end{array}$


A 1.1 .11 .4

$12 / 80$

URANIUM DIOXIDE

Isothermal Compressibility

\section{Isotherma1 Compressibility}

\begin{tabular}{|c|c|c|}
\hline$T, \mathrm{~K}$ & $\underline{B}_{\mathrm{T}} \times 10^{6}, \mathrm{MPa}^{-1}$ & ${ }_{-}^{\mathrm{T}} \mathrm{-} \times 10^{7}, \mathrm{~atm}^{-1}$ \\
\hline 3120 (l) & 41.19 & 41.74 \\
\hline 3200 & $(43.41)^{*}$ & $(43.99)^{*}$ \\
\hline 3300 & $(46.44)$ & $(47.05)$ \\
\hline 3400 & $(49.77)$ & $(50.43)$ \\
\hline 3500 & $(53.10)$ & $(53.80)$ \\
\hline 3600 & $(56.59)$ & $(57.34)$ \\
\hline 3700 & $(60.24)$ & $(61.04)$ \\
\hline 3800 & $(64.08)$ & $(64.93)$ \\
\hline 3900 & $(68.12)$ & $(69.02)$ \\
\hline 4000 & $(72.36)$ & $(73.32)$ \\
\hline 4100 & $(76.84)$ & $(77.86)$ \\
\hline 4200 & $(81.57)$ & $(82.65)$ \\
\hline 4300 & $(86.58)$ & $(87.72)$ \\
\hline 4400 & $(91.88)$ & $(93.10)$ \\
\hline 4500 & $(97.52)$ & $(98.81)$ \\
\hline 4600 & $(103.5)$ & $(104.9)$ \\
\hline 4700 & $(109.9)$ & $(111.4)$ \\
\hline 4800 & $(116.8)$ & $(118.3)$ \\
\hline 4900 & (124.1) & $(125.8)$ \\
\hline 5000 & $(132.0)$ & $(133.8)$ \\
\hline 5100 & $(140.5)$ & $(142.4)$ \\
\hline 5200 & $(149.7)$ & $(151.7)$ \\
\hline 5300 & $(159.7)$ & $(161.8)$ \\
\hline 5400 & $(170.6)$ & $(172.9)$ \\
\hline 5500 & $(182.5)$ & $(184.9)$ \\
\hline 5600 & $(195.6)$ & $(198.2)$ \\
\hline 5700 & $(210.1)$ & $(212.9)$ \\
\hline 5800 & $(226.2)$ & $(229.2)$ \\
\hline 5900 & $(244.2)$ & $(247.4)$ \\
\hline 6000 & $(264.4)$ & $(267.9)$ \\
\hline
\end{tabular}

* Parentheses indicate that the parameters used in the calculation of $\beta_{T}$ have been extrapolated beyong the range of experimental data. 
A 1.1 .11 .5

$12 / 80$

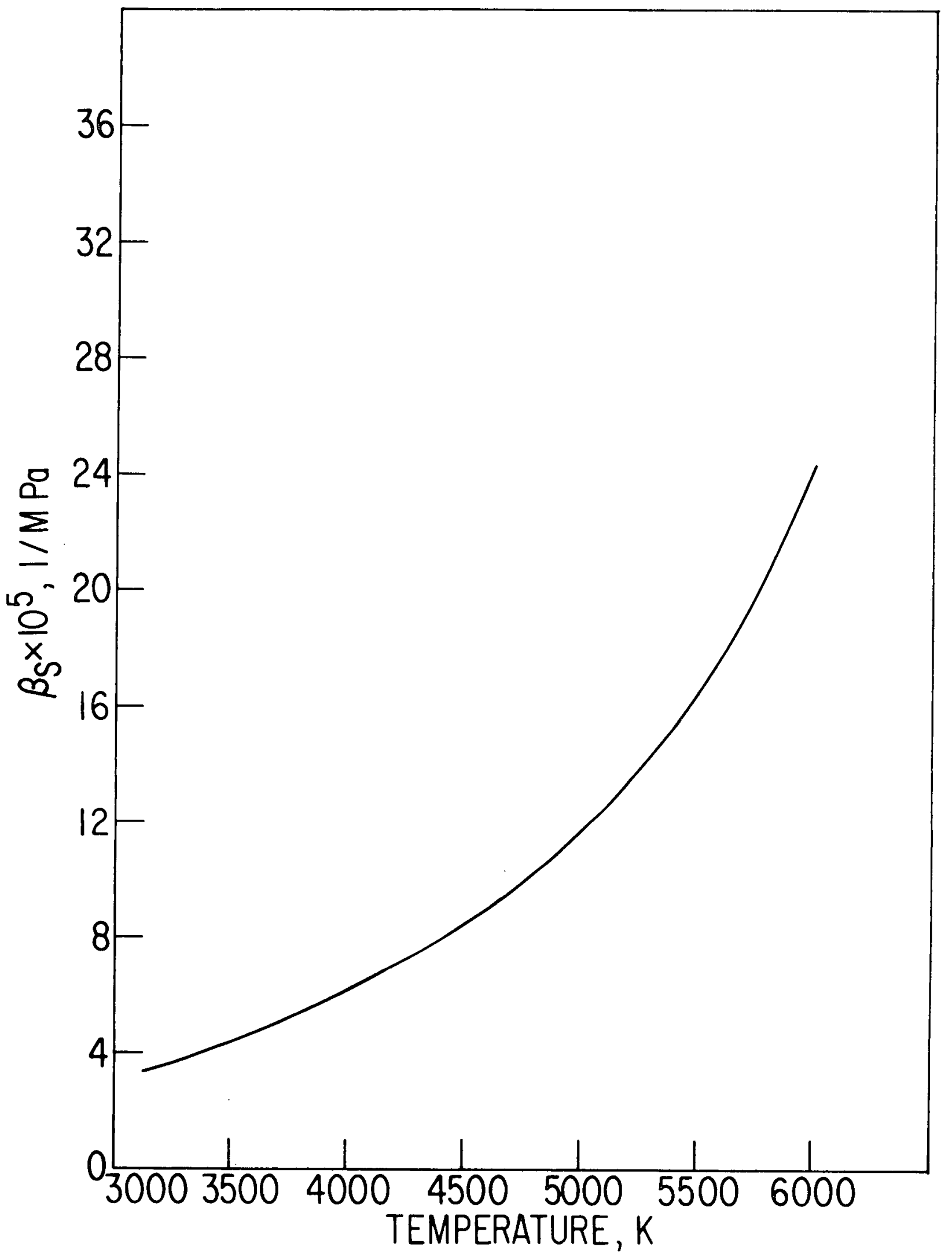

The adiabatic compressibility of liquid $\mathrm{UO}_{2}$. 


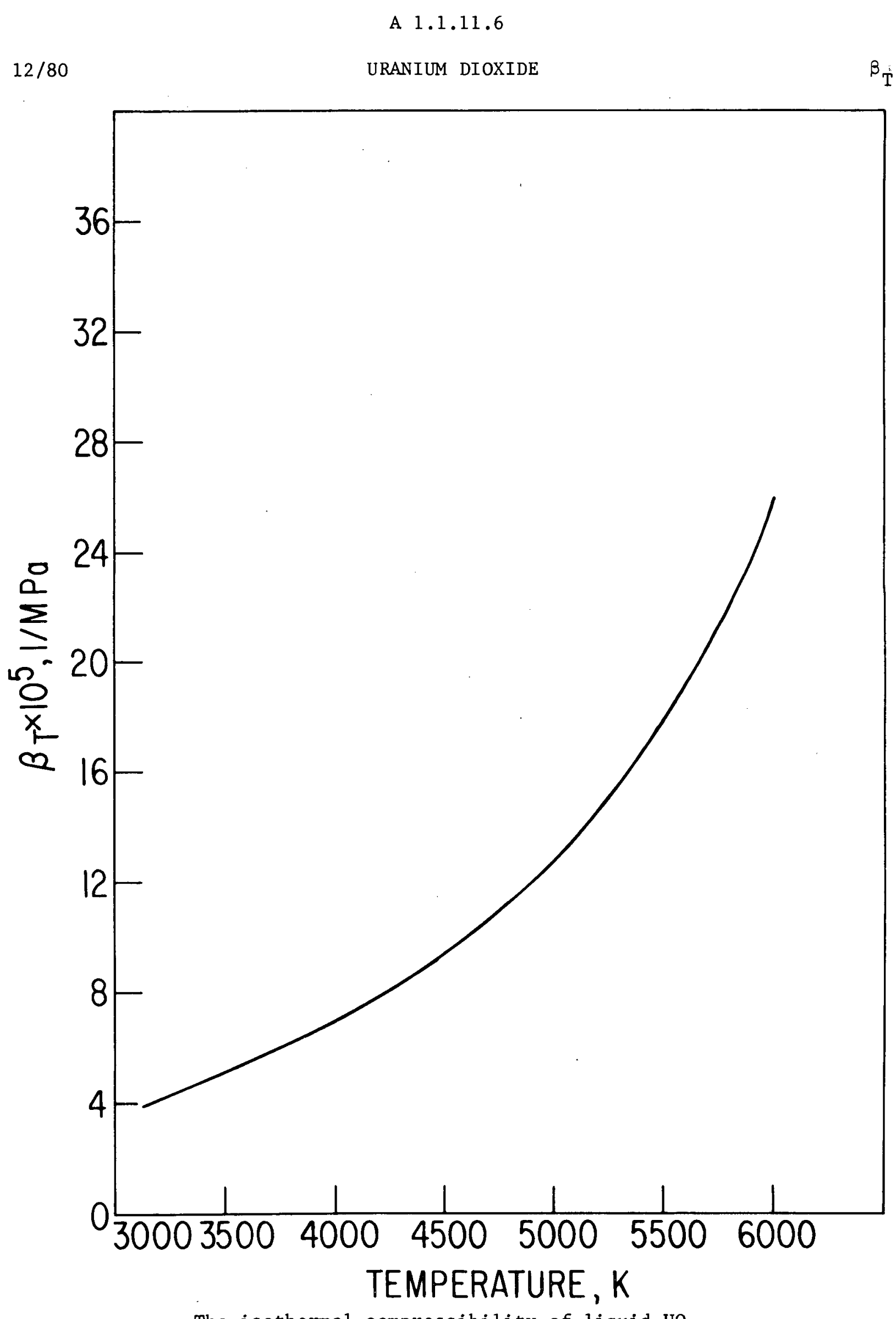

$\mathrm{T}$

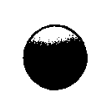


Adiabatic Compressibility

Temperature

Range $\mathrm{T}, \mathrm{K}$

$\beta_{S}, \mathrm{~Pa}^{-1}$

Error

$\sigma, \%$

298-1600 (solid)

\subsection{4}

$2.26 \times 10^{11}\left[1-1.131 \times 10^{-4}(\mathrm{~T}-273.15)\right][1-2.62(1-\mathrm{D})]$

$3120-3400$

$$
\left[10970\left(1.0522-8.192 \times 10^{-5} \mathrm{~T}\right)(3660-0.5769 \mathrm{~T})^{2}\right]^{-1}
$$

$3400-4000$

$4000-5000$

(Grosse approximation)

$5000-6000$ 
Isothermal Compressibility

\begin{tabular}{lrr}
$\begin{array}{c}\text { Temperature } \\
\text { Range T,K }\end{array}$ & $\beta_{\mathrm{T}}, \mathrm{Pa}^{-1}$ & $\begin{array}{c}\text { Error } \\
\sigma, \%\end{array}$ \\
\hline $298-1600$ (solid) & & 3 \\
$3120-3400$ & & 15 \\
$3400-4000$ & $\beta_{S}+\frac{{ }^{\alpha}{ }_{P}{ }^{2} V T}{C_{P}}$ & 20 \\
$4000-5000$ & & 50 \\
$5000-6000$ & & 85
\end{tabular}




\section{Adiabatic Compressibility}

The adiabatic compressibility has been calculated from data on Young's modulus and Poisson's ratio using the expression:

$$
\beta_{S}=\frac{3(1-2 \sigma)}{E}
$$

where $\sigma=$ Poisson's ratio and $E$ = Young's modulus of elasticity.

The equation used to calculate Young's modulus and the value used for Poisson's ratio have been taken from MATPRO-VERSION 11: A Handbook of Material Properties for Use in the Analysis of Light Water Reactor Fuel Rod Behavior. ${ }^{1}$ In the temperature range $0<\mathrm{T}<1600 \mathrm{~K}$, Young's modulus is calculated from the relation:

$$
E=2.26 \times 10^{11}\left[1-1.131 \times 10^{-4}(T-273.15)\right][1-2.62(1-D)]
$$

where $\mathrm{E}=$ Young's modulus in pascals,

$$
T=\text { temperature in } \mathrm{K} \text {, }
$$

and $D=$ fraction of theoretical density.

This equation is based on a least-squares fit to the data for stoichiometric $\mathrm{UO}_{2}$ at room temperature of Marlowe and Kaznoff, ${ }^{2}$ Belle and Lustman, ${ }^{3}$ Lambertson and Handwerk, ${ }^{4}$ and Roberts and Ueda, ${ }^{5}$ and to temperature dependent data of Padel and Novion, ${ }^{6}$ Wachtman et al. ${ }^{7}$ and Belle and Lustman. ${ }^{3}$ The $\mathrm{UO}_{2}$ data have a standard deviation with respect to Eq. (2) of $0.037 \times 10^{11}$. At high temperatures, sliding occurs at grain boundaries in $\mathrm{UO}_{2}$ and in other ceramics. In other ceramics with this phenomena, the elastic modulus exhibits abrupt changes with temperature when sliding occurs. Because abrupt changes with temperature are also 
expected for $\mathrm{UO}_{2}$, and since there is a scarcity of data as a function of temperature and porosity above $1600 \mathrm{~K}$, no equation for Young's modulus above $1600 \mathrm{~K}$ is available and $\mathrm{Eq}$. (2) should not be extrapolated above $1600 \mathrm{~K}$.

The value recommended in MATPRO-VERSION 11 for Poisson's ratio is $0.316 .^{1}$ This value is based on measurements of Young's modulus and the shear modulus on single crystal $\mathrm{UO}_{2}$ at $25^{\circ} \mathrm{C}$ by Wachtman et al.. ${ }^{7}$ From directional measurements on single crystal $\mathrm{UO}_{2}$, Wachtman et al. ${ }^{7}$ calculate the Reuss and Voigt averages of Young's modulus and the shear modulus. The values for nonporous polycrystalline $\mathrm{UO}_{2}$ are assumed to lie between these averages. These midvalues for Young's modulus and the shear modulus are used to determine the recommended value for Poisson's ratio.

No direct measurement of the compressibility of molten $\mathrm{UO}_{2}$ has been reported. The speed of sound in molten $\mathrm{UO}_{2}$ was measured by slagle and Nelson ${ }^{8}$ at 4 points between 3138 and $3196 \mathrm{~K}$. These data can be represented by the equation:

$$
\mathrm{v}=3660-0.5769 \mathrm{~T}
$$

where $v$ is in $\mathrm{m} / \mathrm{s}$ and $\mathrm{T}$ is in kelvins. Equation (3) differs from the original Slagle-Nelsen equation ${ }^{8}$ which had a square root of $\mathrm{T}$ derendence. It was felt that 4 points were insufficient data to justify assuming the square root of $\mathrm{T}$ dependence particularly since it is not evident in the speed of sound of other materals. The adiabatic compresssibility of molten $\mathrm{UO}_{2}, \beta_{S}$, can be calculated using the relation:

$$
\beta_{S}=\frac{1}{\rho v^{2}}
$$




\section{A 1.1 .11 .11}

$12 / 80$

URANIUM DIOXIDE

where $\rho$ is the density of molten $\mathrm{UO}_{2}$ and $\mathrm{v}$ is the speed of sound. The density data of Christensen ${ }^{9}$ can be used in conjunction with the slagle and Nelson values to obtain the adiabatic compressibility in the range of their experimentation. The recommended equation for density ${ }^{10}$ is

$$
\rho=10970\left(1.0522-8.192 \times 10^{-5} \mathrm{~T}\right)
$$

where $\rho$ is in $\mathrm{kg} / \mathrm{m}^{3}$ and $\mathrm{T}$ is in kelvins.

Extrapolation of the speed of sound data to temperatures above $3200 \mathrm{~K}$ is not reliable enough to permit their use in calculation of adiabatic compressibility much beyond that temperature. One finds, however, that simple extrapolation using Eqs. (1-3) for temperatures up to $6000 \mathrm{~K}$ yields results similar to those obtained by using the Grosse method ${ }^{11}$ of fitting the reduced compressibility to reduced temperature via an equilateral hyperbola; however, the reliability of values obtained from either method is questionable at this time.

In order to provide a rough estimate of compressibility values above $3400 \mathrm{~K}$, the Grosse equilateral hyperbola method ${ }^{11}$ has been used. A two parameter equation due to Grosse was used.

$$
\left(\beta^{\prime}+b\right)(\theta+b)=a
$$

where $\beta^{\prime}$ is the reduced adiabatic compressibility

$$
\begin{aligned}
B^{\prime} & =\frac{{ }^{B} S, m}{B_{S, T}} \\
B_{S, m} & =3.3 \times 10^{-11} \mathrm{~Pa}^{-1}
\end{aligned}
$$


and $\theta$ is the fractional liquid temperature between the melting point $(3120 \mathrm{~K})$ and the critical point (estimated as $7560 \mathrm{~K}):^{12}$

$$
\theta=\left(T-T_{m}\right) /\left(T_{c}-T_{m}\right)
$$

By plotting experimental data from 3120 to $3400 \mathrm{~K}$, the parameters a and $b$ were determined as

$$
\begin{aligned}
& a=0.5633 \\
& b=0.4018
\end{aligned}
$$

Solving for ${ }^{B} S, T$

$$
{ }^{B} S, T=\beta_{S, m^{\prime}}\left(\frac{a}{\theta+b}-b\right)
$$

This extrapolation above $3400 \mathrm{~K}$ is clearly conjectural due to the uncertainty in the value of the critical point and the limited data ( $\backsim 58 \mathrm{~K}$ temperature range) on which it is based. The estimated values ${ }^{13}$ for the critical point range from a low value of $6250 \mathrm{~K}$ to a high value of $9332 \mathrm{~K}$. The chosen value $7560 \mathrm{~K}$ of Fischer et al. ${ }^{12}$ is a reasonable mid-value and is also close to other estimates. Comparisons were made of values of ${ }^{B} S$ calculated via extrapolation of Eqs. (3-5) and of values of $\beta_{S}$ calculated with the Grosse method for critical temperatures $6250 \mathrm{~K}, 9332 \mathrm{~K}$, and $7560 \mathrm{~K}$. Below $5500 \mathrm{~K}$, differences in the values calculated by the Grosse method using different critical temperatures were small compared to the difference between the values calculated using the Grosse method and those calculated with the extrapolated equations. From $5500 \mathrm{~K}$ through $6000 \mathrm{~K}$, the differences due to method and choice of critical temperature were of similar magnitude. The estimated errors are based on the largest differences. 


\section{A 1.1 .11 .13}

$12 / 80$

URANIUM DIOXIDE

${ }^{B} S$

The estimated error $(1 \sigma)$ in the recommended values of adiabatic compressibility of solid $\mathrm{UO}_{2}$ below $1600 \mathrm{~K}$ is $2 \%$. This is based on the standard deviation in Young's modulus and the estimated error in the value of Poisson's ratio. Between 3120 and $3400 \mathrm{~K}$ where Eqs. (3-5) are used, the estimated error $(1 \sigma)$ is $8 \%$ based on the errors in the speed of sound equation and the density equation. In the temperature range 3400 through $4000 \mathrm{~K}$, the estimated error $(1 \sigma)$ is $10 \%$. Between 4000 and $5000 \mathrm{~K}$, the error is estimated as $35 \%$. Above $5000 \mathrm{~K}$, the error is estimated as $75 \%$. 


\section{A 1.1 .11 .14}

$12 / 80$

\section{Isothermal Compressibility}

The isothermal compressibility of solid and liquid $\mathrm{UO}_{2}, \mathrm{~B}_{\mathrm{T}}$ was calculated using the relation

$$
\beta_{\mathrm{T}}=\beta_{\mathrm{S}}+\frac{\alpha_{\mathrm{P}}{ }^{2} \mathrm{VT}}{\mathrm{C}_{\mathrm{P}}}
$$

where $\beta_{S}$ is the adiabatic compressibility $\alpha_{P}$ is the volumetric expansion coefficient of $\mathrm{UO}_{2}, \mathrm{~V}$ is the molar volume, and $\mathrm{C}_{\mathrm{P}}$ is the heat capacity. $\alpha_{P}$ and $\rho$ are available from Christensen's work ${ }^{9}$ and $C_{P}$ from the fits of Fink and Leibowitz ${ }^{14}$ and of Rand et al. ${ }^{15}$ The volunetric expansion coefficient for solid $\mathrm{UO}_{2}$ is given by: ${ }^{9,10}$

$$
\alpha_{\mathrm{P}}=\frac{1.7169 \times 10^{-5}+1.4928 \times 10^{-8} \mathrm{~T}+1.0260 \times 10^{-12} \mathrm{~T}^{2}}{0.9980695+5.723 \times 10^{-6} \mathrm{~T}+2.488 \times 10^{-9} \mathrm{~T}^{2}+1.140 \times 10^{-13} \mathrm{~T}^{3}}
$$

where $\alpha_{\mathrm{P}}$ is in $1 / \mathrm{K}$ and $\mathrm{T}$ is in kelvins. The volumetric expansion coefficient for molten $\mathrm{UO}_{2}$ is ${ }^{9}, 10$

$$
\alpha_{\mathrm{P}}=\frac{1.05 \times 10^{-4}}{1+3.5 \times 10^{-5}(\mathrm{~T}-3120)}
$$

The density for $\mathrm{UO}_{2}$ in $\mathrm{kg} / \mathrm{m}^{3}$ is given by the equations: ${ }^{9}, 10$

$$
\begin{aligned}
& 298 \leq \mathrm{T} \leq 3120 \mathrm{~K} \\
& \rho= 10970\left(1.0056-1.6324 \times 10^{-5} \mathrm{~T}-8.3281 \times 10^{-9} \mathrm{~T}^{2}\right. \\
&\left.+2.0176 \times 10^{-13} \mathrm{~T}^{3}\right)
\end{aligned}
$$

$T \geq 3120$

$$
\rho=10970\left(1.0522-8.192 \times 10^{-5} \mathrm{~T}\right)
$$




\section{A 1.1 .11 .15}

$12 / 80$

URANIUM DIOXIDE

The heat capacity at constant pressure is $167 \mathrm{~J} /\left(\mathrm{mol}^{\circ} \mathrm{K}\right)$ for solid $\mathrm{UO}_{2}$ and is $131 \mathrm{~J} /(\mathrm{mol} \cdot \mathrm{K})$ throughout the liquid range. The reliable range for ${ }_{\mathrm{T}}$ is the same as $\beta_{S}$.

The estimated error $(1 \sigma)$ in the calculated values for the isothermal compressibility have been calculated from the error or estimated error in the dependent parameters $C_{P},{ }_{S}, \alpha_{P}$, and 0. Below $1600 \mathrm{~K}$, the calculated standard deviation is $3 \%$. From 3120 through $3400 \mathrm{~K}$, the standard deviation is $15 \%$. Between 3400 and $4000 \mathrm{~K}$, it increased to $20 \%$. From estimated errors, the standard deviation has been calculated to be about $50 \%$ in the 4000 to $5000 \mathrm{~K}$ temperature range and $85 \%$ in the 5000 to $6000 \mathrm{~K}$ range. 
A 1.1 .11 .16

$12 / 80$

URANIUM DIOXIDE

${ }^{B} \mathrm{~T}$

\section{References}

1. D. L. Hagrman and G. A. Reymann, ed. "MATPRO - VERSION 11: A Handbook of Materials Properties for Use in the Analysis of Light Water Reactor Fuel Rod Behavior," EG\&G Report TREE-NUREG-1280 Idaho National Engineering Laboratory (February 1979).

2. M. O. Marlowe and A. I. Kaznoff, J. Am. Ceram. Soc. 53, 90-99 (1970).

3. J. Belle and B. Lustman, "Properties of Uranium Dioxide," in Fuel Elements Conference, Paris, France (November 18-23, 1957), TID-7546, pp. 442-515 (March 1958).

4. W. A. Lambertson and J. H. Handwerk, "The Fabrication and Physical Properties of Urania Bodies," Argonne National Laboratory Report, ANL-5053 (February 1956).

5. J. T. A. Roberts and Y. Ueda, J. Am. Ceram. Soc. 55, pp. 117-124 (1972).

6. A. Padel and C. de Novion, J. Nucl. Mat. 33, pp. 40-51 (1969).

7. J. B. Wachtman, Jr., M. L. Wheat, H. J. Anderson, and J. L. Bates, J. Nuc1. Mat. 16, pp. 39-41 (1965).

8. O. D. Slagle and R. P. Ne1son, J. Nucl. Mat. $\underline{40}, 349$ (1971).

9. J. A. Christensen, J. Am. Ceram. Soc. 40, 607 (1963).

10. O. D. Slagle, private communication (December 1980).

11. A. V. Grosse, Nature 232, 170 (1971).

12. E. A. Fischer, P. Kinsman, and R. W. Ohse, J. Nucl. Mat. 59, 125 (1976).

13. P. Browning, M. T. Gillan, P. E. Potter, and M. H. Rand, The Equation of State of Urania, paper presented at the IWGFR Meeting on Equations of State of Materials of Relevance to the Analysis of Hypothetical Fast Breeder Reactor Accidents, A.E.R.E., Harwe1l, U.K. (June 19-23, 1978). 
A 1.1 .11 .17

$12 / 80$

URANIUM DIOXIDE

$B_{T}$

References (Cont'd)

14. J. K. Fink, M. G. Chasanov, and L. Leibowitz, "Enthalpy and Heat Capacity of Solid $\mathrm{UO}_{2}, "$ (to be published).

15. M. H. Rand, R. J. Ackermann, F. Grbnvold, F. L. Oetting, and

A. Pattoret, Rev. Int. Hautes Temp. et. Refract 15, 355 (1978). 
A 1.1 .12 .1

$12 / 80$

URANIUM DIOXIDE

v

Speed of Sound

\begin{tabular}{|c|c|}
\hline $\mathrm{T}, \mathrm{K}$ & $\mathrm{v}, \mathrm{km} \cdot \mathrm{s}^{-1}$ \\
\hline 3120 (l) & 1.860 \\
\hline 3200 & $(1.814)^{*}$ \\
\hline 3300 & $(1.756)$ \\
\hline 3400 & $(1.698)$ \\
\hline 3500 & $(1.648)$ \\
\hline 3600 & $(1.599)$ \\
\hline 3700 & $(1.554)$ \\
\hline 3800 & $(1.510)$ \\
\hline 3900 & $(1.469)$ \\
\hline 4000 & $(1.429)$ \\
\hline 4100 & $(1.391)$ \\
\hline 4200 & $(1.354)$ \\
\hline 4300 & $(1.319)$ \\
\hline 4400 & $(1.285)$ \\
\hline 4500 & $(1.252)$ \\
\hline 4600 & $(1.220)$ \\
\hline 4700 & $(1.188)$ \\
\hline 4800 & $(1.157)$ \\
\hline 4900 & $(1.127)$ \\
\hline 5000 & $(1.097)$ \\
\hline 5100 & $(1.068)$ \\
\hline 5200 & $(1.039)$ \\
\hline 5300 & $(1.011)$ \\
\hline 5400 & $(0.9825)$ \\
\hline 5500 & $(0.9543)$ \\
\hline 5600 & $(0.9262)$ \\
\hline 5700 & $(0.8981)$ \\
\hline 5800 & $(0.8699)$ \\
\hline 5900 & $(0.8415)$ \\
\hline 6000 & $(0.8128)$ \\
\hline
\end{tabular}

* Parentheses indicate extrapolation beyond the range of experimental data. 
A 1.1 .12 .2

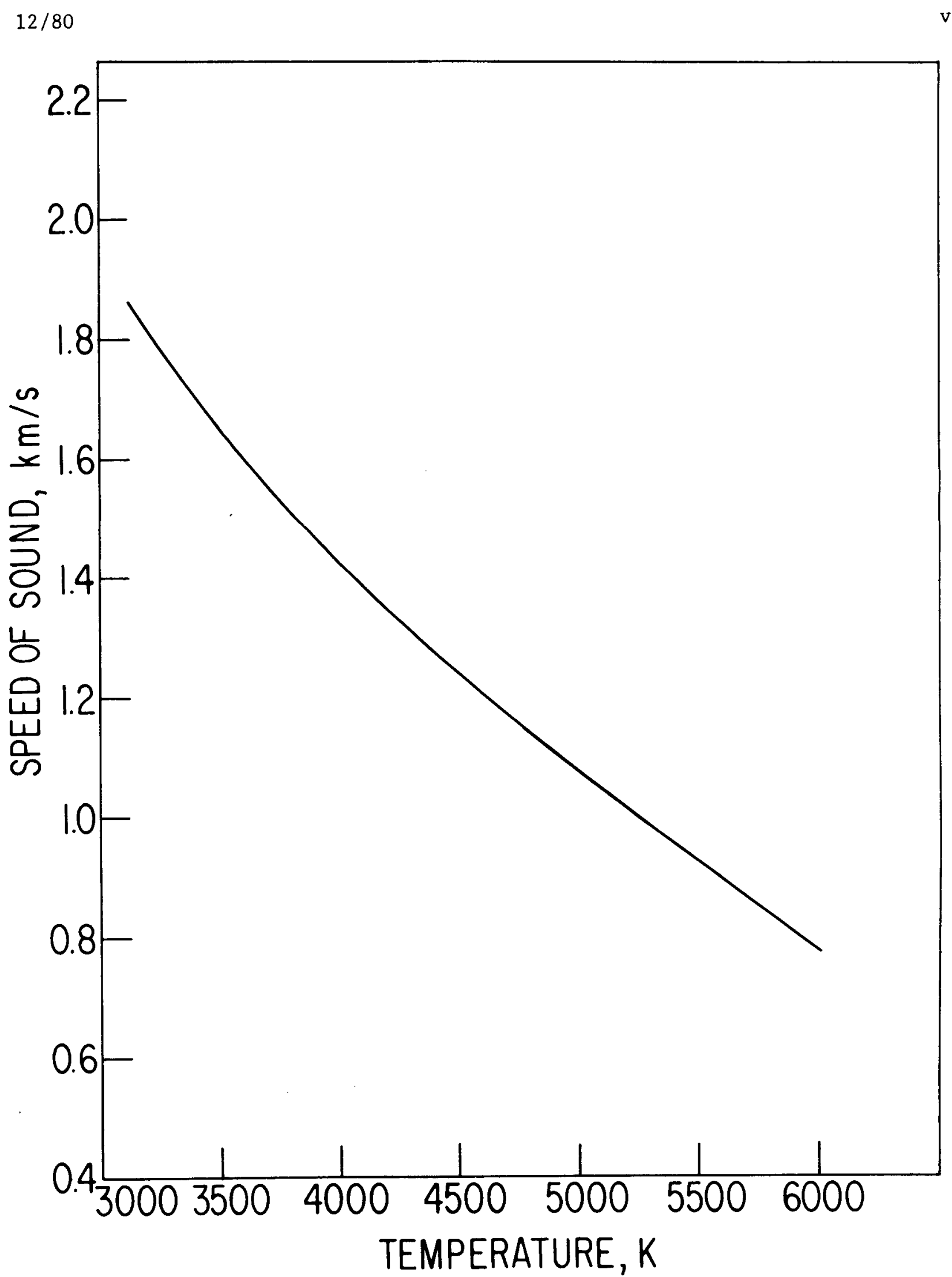

The speed of sound in liquid $\mathrm{UO}_{2}$ 
Speed of Sound

$\left.\begin{array}{lcc}\begin{array}{c}\text { Temperature } \\ \text { Range T,K }\end{array} & \mathrm{v}, \mathrm{m} \cdot \mathrm{s}^{-1} & \begin{array}{c}\text { Error } \\ \sigma, \%\end{array} \\ 3120-3400 & 3660-0.5769 \mathrm{~T} & 4 \\ 3400-4000 \\ 4000-5000 \\ 5000-6000\end{array}\right\} \quad \frac{1}{\sqrt{\rho \beta}} \quad\left\{\begin{array}{l}15 \\ 40 \\ 80\end{array}\right.$




\section{A 1.1 .12 .4}

$12 / 80$

URANIUM DIOXIDE

Speed of Sound

The speed of sound in molten $\mathrm{UO}_{2}$ was measured by Slagle and Nelson ${ }^{1}$. Their data consists of four points between 3138 and $3196 \mathrm{~K}$. These data may be represented by the equation

$$
v=3660-0.5769 \mathrm{~T}
$$

where $v$ is in $\mathrm{m} / \mathrm{s}$ and $\mathrm{T}$ is in kelvins. This equation differs from the Slagle-Nelson equation which is

$$
\mathrm{v}=5268-61.98 \mathrm{~T}^{1 / 2}
$$

where $\mathrm{v}$ is in $\mathrm{m} / \mathrm{s}$ and $\mathrm{T}$ is in kelvins. Eq. (1) was selected over $\mathrm{Eq}$. because there is not sufficient data to justify the square root of $T$ dependence and from measurements of the speed of sound in other materials there appears no reason to expect a square root of temperature dependence. Below $3400 \mathrm{~K}$, the speed of sound has been calculated using Eq. (1). Above $3400 \mathrm{~K}$, the speed of sound was calculated from the adiabatic compressibility using the thermodynamic relation

$$
v=\frac{1}{\sqrt{\rho B_{S}}}
$$

where $\rho$ is the density given by Christensen's ${ }^{2,3}$ equation.

$$
\rho=10970\left(1.0522-8.192 \times 10^{-5} \mathrm{~T}\right)
$$

where $\rho$ is in $\mathrm{kg} / \mathrm{m}^{3}$ and $\mathrm{T}$ is in kelvins. The adiabatic compressibility, ${ }_{\mathrm{S}} \mathrm{S}$, was extrapolated to the $3400-6000 \mathrm{~K}$ temperature range using the Grosse method ${ }^{4}$ of fitting the reduced compressibility to the reduced temperature via an equilateral hyperbola. Such an extrapolation based on 
the limited data ( 4 points from 3138 to $3196 \mathrm{~K}$ ) are open to question. Thus the results should only be used as rough estimates and have large errors associated with them. Using the Grosse method,

$$
\beta_{S}=\beta_{S, m} /\left(\frac{a}{\theta+b}-b\right)
$$

where $\beta_{S, m}$ is the adiabatic compressibility at the melting point, $\theta$ is the reduced temperature, and $a$ and $b$ are parameters determined by the fit to the equilateral hyperbola. The reduced temperature is defined as

$$
\theta=\frac{T-T_{m}}{T_{c}-T_{m}}
$$

where $T_{m}=3120 \mathrm{~K}$, the melting point, and $T_{C}=7560 \mathrm{~K}$, the critical point.

The values used for the adlabatic compressibility at the melting point and the parameters $a$ and $b$ are

$$
\begin{aligned}
\beta_{S, m} & =3.3 \times 10^{-11} \mathrm{~Pa}^{-1} \\
\mathrm{a} & =0.5633 \\
\mathrm{~b} & =0.4018
\end{aligned}
$$

The standard deviation in the fit to the data is $0.2 \%$ but because of the limited amount of data, the estimated error $(\sigma)$ below $3400 \mathrm{~K}$ is estimated as $4 \%$. Above $3400 \mathrm{~K}$, the estimated error is calculated from the errors in the density and the adiabatic compressibility. Since the estimated errors in the adlabatic compressibility are very large, the corresponding errors in the speed of sound are large. Between 3400 and $4000 \mathrm{~K}$, the error in the speed of sound is estimated as $15 \%$. It increases to $40 \%$ in the temperature range $4000-5000 \mathrm{~K}$ and to $80 \%$ above $5000 \mathrm{~K}$. 
A 1.1 .12 .6

$12 / 80$

URANIUM DIOXIDE

References

1. O. D. Slagle and R. P. Nelson, J. Nucl. Mater. 40, 349 (1971).

2. J. A. Christensen, J. Am. Ceram. Soc. 40, 607 (1963).

3. 0. D. Slagle, private communication (December 1980).

3. A. V. Grosse, Nature 232, 170 (1971). 
A 1.1 .13 .1

$12 / 80$

URANIUM DIOXIDE

Critical Constants

Constant
Critical Pressure
Critical Temperature
Critical Density
Critical Compressibility
Factor

$\begin{array}{ccc}\begin{array}{c}\text { Value } \\ \text { (CGS) }\end{array} & \begin{array}{c}\text { Value } \\ (\mathrm{SI})\end{array} & \text { Range of Estimates } \\ 1210 \mathrm{~atm} & 122.6 \mathrm{MPa} & 65 \\ 7560 \mathrm{~K} & 7560 \mathrm{~K} & 23 \\ 1.66 \mathrm{~g} \cdot \mathrm{cm}^{-3} & 1660 \mathrm{~kg} \cdot \mathrm{m}^{-3} & 97 \\ 0.317 & 0.317 & 23\end{array}$

$$
{ }^{\mathrm{T}} \mathrm{C}, \mathrm{P}_{\mathrm{C}},{ }_{\mathrm{C}}
$$


A 1.1 .13 .2

$12 / 80$

URANIUM DIOXIDE

${ }_{\mathrm{C}}^{\mathrm{T}}, \mathrm{P}_{\mathrm{C}}, \mathrm{P}_{\mathrm{C}}$

\section{Critical Constants}

A large number of calculations of the critical constants of $\mathrm{UO}_{2}$ have been made. ${ }^{1-10}$ Results of these calculations are tabulated by date along with a comment on the method of calculation. Three main methods were used: the Grosse method of rectilinear diameters, ${ }^{11,12}$ the law of corresponding states, 13,14 and the significant structures theory. ${ }^{15}$

The recommended critical constants are values calculated by Fischer, Kinsman, and Ohse $^{7}$ using the significant structures theory. The values were chosen by selecting a critical temperature near the mean of the various estimates that range from 6150 through $9332 \mathrm{~K}$. The range of estimate expressed as a percent based on the deviation of the other estimated values of the critical parameters from the recommended value. In calculation of the estimated error of the critical pressure, the value 6958 atm was not included since it is so far from the other values. Similarly, the value 1.0 was not included in the calculation of error of the critical coefficient of compressibility and the value $31.8 \mathrm{~g} / \mathrm{cc}$ was dropped from the values of critical density used in estimating the error. 


\begin{tabular}{|c|c|c|c|c|c|c|c|}
\hline $\begin{array}{l}T_{C} \\
R \\
\end{array}$ & $\begin{array}{c}\nabla_{\mathrm{C}} \\
\mathrm{cc} / \mathrm{mole} \\
\end{array}$ & $\begin{array}{c}P_{C} \\
g / c c \\
\end{array}$ & $\begin{array}{l}{ }^{{ }_{C}} \\
\text { atm } \\
\end{array}$ & $\mathrm{z}_{\mathrm{C}}$ & Year & Reference & \\
\hline 7300 & 8.5 & 31.8 & 1900 & & 1964 & Meyer and Wolf & (1) \\
\hline 9115 & 170 . & 1.59 & 1230 & & 1965 & Miller & (2) \\
\hline 8000 & 89.9 & 3.01 & 2000 & 0.27 & 1966 & Menzies & (3) \\
\hline $\begin{array}{r}5500- \\
10,000\end{array}$ & -- & - & - & - & 1966 & Robbins & (4) \\
\hline 6723 & 98.9 & 2.73 & 1404 & 0.2513 & 1968 & Booth & (5) \\
\hline 6960 & 165 . & 1.64 & 1070 & 0.308 & 1975 & Gillan & (6) \\
\hline 9332 & 166. & 1.63 & 1450 & 0.308 & 1975 & Gillan & (6) \\
\hline 7560 & 163. & 1.66 & 1210 & 0.317 & 1976 & Fischer et al. & (7) \\
\hline 6744 & 98.5 & 2.74 & 1404 & 0.25 & 1976 & Kapil & (8) \\
\hline 6723 & 98.7 & 2.74 & 1404 & 0.2513 & 1978 & Browning et a1. & (9) \\
\hline 6820 & 98.4 & 2.74 & 1380 & 0.2126 & 1978 & Browning et al. & (9) \\
\hline 7200 & 93.1 & 2.90 & - & -- & 1978 & Browning et al. & (9) \\
\hline 6250 & 84.3 & 3.20 & -- & -- & 1978 & Browning et al. & (9) \\
\hline 7320 & 152. & 1.78 & 1256 & 0.318 & 1978 & Browning et al. & (9) \\
\hline 8840 & 158 . & 1.71 & 1424 & 0.310 & 1978 & Browning et al. & (9) \\
\hline 6960 & 165. & 1.64 & 1070 & 0.309 & 1978 & Browning et a1. & (9) \\
\hline 9332 & 166. & 1.63 & 1450 & 0.314 & 1978 & Browning et a1. & (9) \\
\hline 7365 & 90.4 & 2.99 & 6958 & 1.00 & 1979 & Finn et al. & (10) \\
\hline 6464 & 82.6 & 3.27 & 1734 & 0.27 & 1979 & Finn et al. & (10) \\
\hline
\end{tabular}

Method
Corresponding states
Law of rectflinear diameters
Corresponding states, assuming, $\mathrm{Z}_{\mathrm{C}}$, using vapor pressure of
Ackermann et al., (Ref. 16)
Corresponding states
Corresponding states
Significant structures theory with bent molecule and vapor
pressure of Ohse (Ref. 17)
Significant structures theory with bent molecule and vapor
pressure of Tetenbaum and Hunt (Ref. 18)
Significant structures theory
Corresponding states using data of ohse (Ref. 17) and of
Ackermann (Ref. 16)
Corresponding states using vapor pressure of ohse (Ref. 17)
Corresponding states using vapor pressure of Tetenbaum and
Hunt (Ref. 18)
Law of rectilinear diameters using vapor pressure of ohse
(Ref. 17 )

Law of rectilinear diameters using vapor pressure of Tetenbaum and Hunt (Ref. 18)

Significant structures theory using vapor pressure of Ohse (Ref. 17)

Significant structures theory using vapor pressure of Tetenbaum and Hunt (Ref. 18)

Significant structures theory using Gillan's bent molecule and vapor pressure of ohse (Ref. 17)

Significant structures theory using Gillan's bent molecule and vapor pressure of Tetenbaum and Hunt (Ref. 18)

Law of rectllinear diameters using vapor pressure of Tetenbaum and Hunt with $\mathrm{z}_{\mathrm{C}}=1.0$ (Ref. 18)

Law of rectilinear diameters using vapor pressure of Tetenbaum and Hunt (Ref. 18) 
A 1.1 .13 .4

$12 / 80$

URANIUM DIOXIDE

$$
{ }^{\mathrm{T}}{ }_{\mathrm{C}}, \mathrm{P}_{\mathrm{C}}, \rho_{\mathrm{C}}
$$

\section{References}

1. R. A. Meyer and B. E. Wolfe, Trans Am. Nuc1. Soc. 1 Vol. 1,11 (1964).

2. D. Miller, Argonne National Laboratory Report ANL-7120, 64, Argonne, IL (1965).

3. C. Menzies, UKAEA Report TRG-1119(D), London (1966).

4. E. J. Robbins, UKAEA Report TRG-1344(D), London (1966).

5. D. L. Booth, UKAEA Report TRG-1759(RH), London (1968) (reissued 1974).

6. M. J. Gillan, Thermodynamics of Nuclear Materials I.A.E.A Vienna, Vol. 1, p. 629 (1975).

7. E. A. Fischer, P. Kinsman, R. W. Ohse, J. Nuc1. Mat. 59, 125 (1976).

8. S. K. Kapil, J. Nuc1. Mat. 60 , 158 (1976).

9. P. Browning, M. J. Gillan, P. E. Potter, and M. H. Rand, The Equation of State of Urania, Paper presented at the IWGFR Meeting on Equations of State of Materials of relevance to the analysis of hypothetical fast breeder reactor accidents A.E.R.E, Harwe11, U.K., (June 19-23, 1978).

10. P. A. Finn, A. Sheth, and L. Leibowitz, J. Nucl. Mat. 79, 14 (1979).

11. A. V. Grosse, J. Inorg. Nuc1. Chem. 22, 23 (1961).

12. A. D. Kirschenbaum, J. A. Cahill, P. J. McGonigal, and A. V. Grosse, J. Inorg. Nucl. Chem. 24, 1287 (1962). 


\section{A 1.1 .13 .5}

$12 / 80$

13. J. 0. Hirschfelder, C. Curtiss, and R. Bird, Molecular Theory of Gases and Liquids, John Wiley and Co., New York (1964).

14. L. Riedel, Chem. Ing. Tech. 26, 83 (1954).

15. H. Eyring and M. S. Jhon, Significant Liquid Structure, John Wiley and Co., New York (1969).

16. R. J. Ackermann, P. W. Gilles, and R. H. Thorn, J. Chem. Phys. $\underline{25}$, 1089 (1956).

17. R. W. Ohse, J. Chem. Phys. 44, 1375 (1966).

18. M. Tetenbaum and P. D. Hunt, J. Nuc1. Mat. 34, 86 (1970). 
$A-1$

TABULATED THERMODYNAMIC PROPERTIES

IN SI UNITS 
THPEGODYMAIC PKOPEETIES OP SOLID URAMIOA DIOXIDE

\begin{tabular}{|c|c|c|c|c|c|c|c|c|c|}
\hline$\frac{T}{(R)}$ & $\begin{array}{l}B-B(29 B) \\
(J / \triangle O L)\end{array}$ & $\begin{array}{c}\text { CP } \\
(\mathrm{J} / \mathrm{MOL}-\mathrm{K})\end{array}$ & $\begin{array}{c}C V \\
(\mathrm{~J} / \mathrm{MOL}-\mathrm{K})\end{array}$ & $\stackrel{P}{(I P A)}$ & $\begin{array}{c}F B O \\
(K G / M * * 3)\end{array}$ & $\begin{array}{c}\text { ALPHAP } \\
(1 / K)\end{array}$ & $\begin{array}{l}\text { BETAS } \\
(1 / P A)\end{array}$ & $\begin{array}{l}\text { BETAT } \\
(1 / \mathrm{PA})\end{array}$ & $\begin{array}{l}\text { GAYHAV } \\
\text { (PA/K) }\end{array}$ \\
\hline 298 & 0.0 & $6.3596 \mathrm{D}+01$ & $6.2897 D+01$ & 0.0 & $1.0970 D+04$ & $2.1711 \mathrm{D}-05$ & $4.8988 D-12$ & $4.9532 D-12$ & $4.38320+06$ \\
\hline 300 & $1.1783 D+02$ & $6.3790 D+01$ & $6.3085 D+01$ & 0.0 & $1.09700+04$ & $2.1739 D-05$ & $4.69980-12$ & $4.35450-12$ & $4.3878 D+06$ \\
\hline 310 & $7.6081 D+02$ & $6.4793 \mathrm{D}+01$ & $6.4056 \mathrm{D}+01$ & 0.0 & $1.09670+04$ & $2.1893 \mathrm{D}-05$ & $4.9054 D-12$ & $4.96190-12$ & $4.41230+06$ \\
\hline 320 & $1.4135 D+03$ & $6.5726 D+01$ & $6.4955 D+01$ & 0.0 & $1.0965 D+04$ & $2.2048 D-05$ & $4.9110 \mathrm{D}-12$ & $4.9693 D-12$ & $4.43680+06$ \\
\hline 330 & $2.0751 D+03$ & $6.65940+01$ & $6.5789 D+01$ & 0.0 & $1.0962 D+24$ & 2. $2202 \mathrm{D}-05$ & $4.9166 \mathrm{D}-12$ & $4.9767 D-12$ & $4.46110+06$ \\
\hline 340 & $2.74510+03$ & $6.74040+01$ & $6.6564 D+01$ & 0.0 & $1.09600+04$ & $2.2356 \mathrm{D}-05$ & $4.9222 D-12$ & $4.98430-12$ & $4.48530+06$ \\
\hline 350 & $3.42300+03$ & $6.81600+01$ & $6.7285 D+01$ & 0.0 & $1.0958 D+04$ & 2. $2511 \mathrm{D}-05$ & $4.9278 D-12$ & $4.9919 D-12$ & 4. $50950+06$ \\
\hline 360 & $4.1082 D+03$ & $6.8868 D+01$ & $6.79570+01$ & 0.0 & $1.09550+04$ & $2.2666 \mathrm{D}-05$ & $4.9334 D-12$ & $4.9996 \mathrm{D}-12$ & $4.53 j 5 D+06$ \\
\hline 370 & $4.8002 D+03$ & $6.9533 D+01$ & $6.8584 D+01$ & 0.0 & $1.09530+04$ & $2.28210-05$ & $4.93910-12$ & $5.00740-12$ & $4.55740+06$ \\
\hline 380 & $5.4987 D+03$ & $7.01570+01$ & $6.9170 D+01$ & 0.0 & $1.0950 D+04$ & $2.2976 \mathrm{D}-05$ & $4.9447 D-12$ & $5.0152 D-12$ & $4.58120+06$ \\
\hline 390 & $6.2032 D+03$ & $7.07440+01$ & $6.97190+01$ & 0.0 & $1.09480+04$ & $2.31310-05$ & $4.9504 D-12$ & $5.0231 D-12$ & $4.6049 D+06$ \\
\hline 400 & $6.91350+03$ & $7.1297 D+01$ & $7.02340+01$ & $3.66200-71$ & $1.09450+04$ & $2.3287 D-05$ & $4.95610-12$ & $5.03110-12$ & $4.6285 D+06$ \\
\hline 410 & $7.6291 \mathrm{D}+03$ & $7.18200+01$ & $7.0717 D+01$ & $2.9599 D-69$ & $1.09430+04$ & $2.3442 \mathrm{D}-05$ & $4.96180-12$ & $5.0392 \mathrm{D}-12$ & $4.6520 D+06$ \\
\hline 420 & e. $3498 D+03$ & $7.23150+01$ & $7.11710+01$ & $1.9409 D-67$ & $1.09400+04$ & $2.35980-05$ & $4.9675 D-12$ & $5.04730-12$ & $4.6 .754 D+C 6$ \\
\hline 430 & $9.07530+03$ & $7.2783 D+01$ & $7.15980+01$ & $1.0477 D-65$ & $1.0938 D+04$ & $2.37540-05$ & $4.9732 D-12$ & $5.05550-12$ & $4.6987 \mathrm{D}+06$ \\
\hline 440 & $9.00540+03$ & $7.3227 D+C 1$ & $7.2001 \mathrm{D}+01$ & $4.7176 D-64$ & $1.09350+04$ & $2.39100-05$ & $4.97890-12$ & $5.0637 \mathrm{D}-12$ & $4.7218 D+06$ \\
\hline 450 & $1.05400+04$ & $7.3650 D+C 1$ & $7.2381 D+01$ & $1.7936 \mathrm{D}-62$ & $1.09330+04$ & $2.4066 \mathrm{D}-05$ & $4.9847 \mathrm{D}-12$ & $5.0721 D-12$ & $4.74490+06$ \\
\hline 460 & $1.1278 D+04$ & $7.4052 D+01$ & $7.27390+01$ & $5.82130-61$ & $1.0930 D+04$ & $2.4223 \mathrm{D}-05$ & $4.99040-12$ & $5.08050-12$ & $4.76700+06$ \\
\hline 470 & $1.2021 D+C 4$ & $7.4435 D+01$ & $7.30780+01$ & $1.6294 D-59$ & $1.0927 D+04$ & $2.438 .30-05$ & $4.9962 \mathrm{D}-12$ & $5.0889 D-12$ & $4.79070+06$ \\
\hline 480 & $1.2767 D+04$ & $7.48000+01$ & $7.33990+01$ & $3.9693 D-58$ & $1.0925 D+04$ & $2.45360-05$ & $5.00200-12$ & $5.0975 D-12$ & $4.81350+06$ \\
\hline 490 & $1.3517 D+04$ & $7.51500+01$ & $7.3703 D+01$ & $8.48830-57$ & $1.09220+04$ & $2.4693 \mathrm{D}-05$ & $5.0078 D-12$ & $5.10610-12$ & $4.83610+06$ \\
\hline 500 & $1.42700+04$ & $7.5484 \mathrm{D}+01$ & $7.3951 D+01$ & $1.6059 D-55$ & $1.09190+04$ & $2.48510-05$ & $5.0130 \mathrm{D}-12$ & $5.1147 D-12$ & $4.85860+06$ \\
\hline 510 & $1.50260+04$ & $7.58040+01$ & $7.42650+01$ & $2.7073 D-54$ & $1.0917 D+04$ & $2.50080-05$ & $5.0194 \mathrm{D}-1.2$ & $5.1235 D-12$ & $4.88100+06$ \\
\hline 520 & $1.5786 \mathrm{D}+04$ & $7.61120+01$ & $7.45240+01$ & $4.0943 D-53$ & $1.09140+04$ & $2.51650-05$ & $5.02530-12$ & $5.13230-12$ & $4.90330+06$ \\
\hline 530 & $1.6549 D+04$ & $7.6407 D+01$ & $7.47710+01$ & $5.58860-52$ & $1.09110+04$ & $2.53230-05$ & $5.03110-12$ & $5.14120-12$ & $4.9255 D+06$ \\
\hline 540 & $1.73140+04$ & $7.66910+01$ & $7.5006 \mathrm{D}+01$ & $6.9244 \mathrm{D}-51$ & $1.09080+04$ & $2.54810-95$ & $5.0370 \mathrm{D}-12$ & $5.15010-12$ & $4.9476 \mathrm{D}+06$ \\
\hline
\end{tabular}


THEBMODYNAMIC PEGPEPTIES OP SOLID ORANIUA DIOXIDE

\begin{tabular}{|c|c|c|c|c|c|c|c|c|c|}
\hline $\begin{array}{l}T \\
(K)\end{array}$ & $\begin{array}{l}H-H(298) \\
(J / H O L)\end{array}$ & $\begin{array}{c}C P \\
(\mathrm{~J} / \mathrm{MOL}-\mathrm{K})\end{array}$ & $\begin{array}{c}\mathrm{CV} \\
(\mathrm{J} / \mathrm{MOL}-\mathrm{K})\end{array}$ & $\begin{array}{c}P \\
(U P A)\end{array}$ & $\begin{array}{c}B H O \\
(K G / M * * 3)\end{array}$ & $\begin{array}{c}A L P H A P \\
(1 / R)\end{array}$ & $\begin{array}{l}\text { BETAS } \\
(1 / \mathrm{PA})\end{array}$ & $\begin{array}{c}\text { BFTAT } \\
(1 / \mathrm{PA})\end{array}$ & $\begin{array}{l}\text { GAM MAV } \\
\text { (PA/K) }\end{array}$ \\
\hline 550 & $1.8 C 82 D+04$ & $7.6965 \mathrm{D}+\mathrm{C} 1$ & $7.52300+01$ & $7.8292 \mathrm{D}-50$ & $1.0906 \mathrm{D}+04$ & $2.5639 \mathrm{D}-05$ & $5 . C 429 D-12$ & $5.1592 \mathrm{D}-12$ & $4.9696 D+06$ \\
\hline 560 & $1.8853 \mathrm{D}+04$ & $7.7228 \mathrm{D}+01$ & $7.5442 D+C 1$ & $8.11770-49$ & $1.09030+04$ & $2.57970-05$ & $5.0488 D-12$ & $5.16830-12$ & $4.9914 D+06$ \\
\hline 570 & $1.56270+04$ & $7.74830+01$ & $7.56450+01$ & $7.7536 D-48$ & $1.09000+04$ & $2.59550-05$ & $5.0547 D-12$ & $5.17740-12$ & $5.01310+06$ \\
\hline 580 & $2.0403 D+04$ & $7.77290+01$ & $7.5839 D+01$ & $6.85150-47$ & $1.08970+04$ & $2.61140-05$ & $5.06060-12$ & $5.1867 \mathrm{D}-12$ & $5.0348 D+06$ \\
\hline 590 & $2.1181 D+04$ & $7.7966 \mathrm{D}+01$ & $7.6 C 24 D+01$ & $5.6233 D-46$ & $1.08940+04$ & $2.6272 D-05$ & $5.0665 \mathrm{D}-12$ & $5.1960 D-12$ & $5.05630+06$ \\
\hline 600 & 2. $1962 D+04$ & $7.81970+01$ & $7.6200 D+01$ & 4. $3025 D-45$ & $1.0892 D+04$ & $2.64310-05$ & $5.0725 \mathrm{D}-12$ & $5.2054 D-12$ & $5.0777 D+06$ \\
\hline 610 & $2.2745 \mathrm{D}+04$ & $7.8420 D+01$ & $7.6369 \mathrm{D}+01$ & $3.0794 D-44$ & $1.08890+04$ & $2.65900-05$ & $5.0784 D-12$ & $5.2148 D-12$ & $5.09890+06$ \\
\hline $62 \mathrm{C}$ & $2.3531 D+04$ & $7.8636 \mathrm{D}+01$ & $7.6530 D+01$ & $2.0685 D-43$ & $1.0886 \mathrm{D}+04$ & $2.67490-05$ & $5.08440-12$ & $5.22430-12$ & $5.12010+06$ \\
\hline 630 & $2.43180+04$ & $7.88460+01$ & $7.6684 D+01$ & $1.3079 D-42$ & $1.08830+04$ & $2.6908 D-05$ & $5.0904 \mathrm{D}-12$ & $5.23400-12$ & 5. $14110+06$ \\
\hline 640 & $2.51070+04$ & $7.9051 \mathrm{D}+01$ & $7.68310+C 1$ & $7.8067 D-42$ & $1.08800+04$ & $2.70680-05$ & $5.09640-12$ & $5.2436 \mathrm{D}-12$ & 5. $1621 \mathrm{D}+06$ \\
\hline 657 & $2.5899 \mathrm{D}+04$ & $7.92490+01$ & $7.6972 \mathrm{D}+01$ & $4.4105 D-41$ & $1.08770+04$ & $2.7227 D-05$ & $5.1024 \mathrm{D}-12$ & $5.2534 \mathrm{D}-12$ & $5.1829 D+06$ \\
\hline 660 & $2.66920+04$ & $7.9443 \mathrm{D}+01$ & $7.71070+01$ & $2.3644 D-4 C$ & $1.0874 \mathrm{D}+04$ & $2.7387 D-05$ & $5.1085 D-12$ & $5.2632 \mathrm{D}-12$ & $5.2035 \mathrm{D}+06$ \\
\hline 670 & $2.7488 \mathrm{D}+04$ & $7.96310+01$ & $7.7236 D+C 1$ & $1.2055 D-39$ & $1.0871 \mathrm{D}+04$ & $2.7547 \mathrm{D}-05$ & $5.1145 D-12$ & $5.2731 \mathrm{D}-12$ & $5.22410+06$ \\
\hline 680 & $2.8285 D+04$ & $7.96150+01$ & $7.7360 \mathrm{D}+01$ & $5.85910-39$ & $1.08680+04$ & $2.7707 \mathrm{D}-05$ & $5.1206 \mathrm{D}-12$ & $5.28310-12$ & $5.24450+06$ \\
\hline 690 & $2.90840+04$ & $7.99940+01$ & $7.7478 \mathrm{D}+01$ & $2.72010-38$ & $1.08650+04$ & $2.7867 D-05$ & $5.1267 D-12$ & $5.2931 \mathrm{D}-12$ & $5.2648 D+06$ \\
\hline 730 & $2.98850+04$ & $8.0169 \mathrm{D}+01$ & $7.7592 \mathrm{D}+01$ & $1.2086 \mathrm{D}-37$ & $1.0862 D+04$ & $2.8028 D-05$ & $5.1327 D-12$ & $5.30330-12$ & $5.28500+06$ \\
\hline 710 & $3.0687 D+04$ & $P .0341 \mathrm{D}+01$ & $7.77000+01$ & $5.1493 \mathrm{D}-37$ & $1.08590+04$ & $2.8188 D-05$ & $5.1389 D-12$ & $5.3135 D-12$ & $5.30510+06$ \\
\hline 720 & $3.1492 \mathrm{D}+04$ & $8.0508 D+01$ & 7. $7804 \mathrm{D}+01$ & $2.1073 D-36$ & $1.0856 D+04$ & $2.83490-05$ & $5.1450 \mathrm{D}-12$ & $5.3238 D-12$ & $5.3250 D+06$ \\
\hline 732 & $3.22980+04$ & $8.06720+01$ & $7.7904 \mathrm{D}+01$ & $8.29700-36$ & $1.0853 \mathrm{D}+24$ & $2.85100-05$ & $5.15110-12$ & $5.33410-12$ & $5.3449 D+06$ \\
\hline 740 & 3. $3105 D+04$ & $8.0832 \mathrm{D}+01$ & $7.80000+01$ & $3.1480 D-35$ & $1.08500+04$ & $2.86710-05$ & $5.1573 D-12$ & $5.3446 D-12$ & $5.36450+06$ \\
\hline 750 & $3.39140+04$ & $8.09900+01$ & $7.8091 D+01$ & $1.1527 D-34$ & $1.08470+04$ & $2.8832 \mathrm{D}-05$ & $5.1634 D-12$ & $5.3551 D-12$ & $5.38410+06$ \\
\hline 760 & $3.4725 D+04$ & 8. $1144 D+01$ & $7.81790+01$ & $4.0790 D-34$ & $1.0844 D+04$ & $2.89940-05$ & $5.1696 D-12$ & $5.36570-12$ & $5.4035 D+06$ \\
\hline 770 & $3.5537 D+04$ & $8.1295 D+01$ & $7.82630+01$ & $1.3968 D-33$ & $1.08430+34$ & $? .9155 D-05$ & $5.1758 D-12$ & $5.3764 D-12$ & $5.4220 D+06$ \\
\hline 780 & $3.63510+04$ & $8.1444 D+01$ & $7.83430+01$ & $4.6347 \mathrm{D}-33$ & $1.0837 D+04$ & $2.93170-05$ & $5.1820 D-12$ & $5.38710-12$ & $5.4420 D+06$ \\
\hline 790 & $3.7166 \mathrm{D}+04$ & $8.15900+01$ & $7.8420 D+01$ & $1.4918 D-32$ & $1.2834 D+04$ & $2.9479 \mathrm{D}-05$ & $5.1882 \mathrm{D}-12$ & $5.39800-12$ & $5.46110+06$ \\
\hline 800 & $3.7983 D+C 4$ & $8.17330+C 1$ & $7.8494 \mathrm{D}+01$ & $4.6635 D-32$ & $1.08310+04$ & $2.9641 D-J 5$ & $5.1945 D-12$ & $5.110890-12$ & $5.48000+05$ \\
\hline
\end{tabular}


THERMODINALIC PEOPEFTIES OF SOLID UAANIUL DIOXIDE

\begin{tabular}{|c|c|c|c|c|c|c|c|c|c|}
\hline $\begin{array}{c}T \\
(K)\end{array}$ & $\begin{array}{l}B-8(298) \\
(J / 9 O L)\end{array}$ & $\begin{array}{c}C P \\
(J / H O L-K)\end{array}$ & $\begin{array}{c}C V \\
(\mathrm{~J} / \mathrm{MOL}-\mathrm{K})\end{array}$ & $\begin{array}{c}P \\
\text { (MPA) }\end{array}$ & $\begin{array}{c}B H O \\
(K G / A * * 3)\end{array}$ & $\begin{array}{c}\text { ALPHAP } \\
(1 / K)\end{array}$ & $\begin{array}{l}\text { BETAS } \\
(1 / \mathrm{PA})\end{array}$ & $\begin{array}{r}\text { BETAT } \\
(1 / \mathrm{PA})\end{array}$ & $\begin{array}{l}\text { GAMGAV } \\
\text { (PA/R) }\end{array}$ \\
\hline 810 & $3.88010+04$ & $8.1875 \mathrm{D}+01$ & $7.8564 \mathrm{D}+01$ & $1.4174 \mathrm{D}-31$ & $1.0828 D+04$ & $2.98030-05$ & $5.2007 D-12$ & $5.4199 \mathrm{D}-12$ & $5.49880+06$ \\
\hline 820 & $3.96200+04$ & $8.2013 D+01$ & $7.8631 \mathrm{D}+01$ & $4.1927 \mathrm{D}-31$ & $1.0824 D+04$ & $2.9965 \mathrm{D}-05$ & $5.20700-12$ & $5.4310 \mathrm{D}-12$ & $5.51750+06$ \\
\hline 830 & $4.04410+04$ & $8.215 \cup D+01$ & $7.8696 \mathrm{D}+01$ & $1.2082 \mathrm{D}-30$ & $1.0821 D+04$ & $3.01230-05$ & $5.2133 \mathrm{D}-12$ & $5.44210-12$ & $5.5360 D+06$ \\
\hline 840 & $4.1263 D+04$ & 8. $2285 D+01$ & $7.8757 D+01$ & $3.3952 \mathrm{D}-3 \mathrm{C}$ & $1.0818 D+04$ & $3.0290 D-05$ & $5.21960-12$ & $5.45340-12$ & $5.55440+06$ \\
\hline 850 & $4.20870+04$ & $8.24170+01$ & $7.88160+01$ & $9.3113 \mathrm{D}-30$ & $1.0815 D+04$ & $3.0453 \mathrm{D}-05$ & $5.2259 D-12$ & $5.4647 D-12$ & $5.5726 D+06$ \\
\hline 860 & $4.29110+04$ & $8.2548 \mathrm{D}+01$ & $7.8872 D+01$ & $2.4944 D-29$ & $1.08110+04$ & $3.0616 \mathrm{D}-05$ & $5.2322 D-12$ & $5.47610-12$ & $5.59080+06$ \\
\hline $87 \mathrm{C}$ & $4.37380+04$ & $8.26770+01$ & 7. $8925 D+01$ & $6.5327 D-29$ & $1.08080+04$ & $3.07790-05$ & $5.2386 \mathrm{D}-12$ & $5.4876 \mathrm{D}-12$ & $5.6088 D+06$ \\
\hline 880 & $4.45650+04$ & $8.2805 D+01$ & $7.8976 \mathrm{D}+01$ & $1.6739 \mathrm{D}-28$ & $1.0805 D+04$ & $3.0942 D-05$ & $5.2449 \mathrm{D}-12$ & $5.4992 \mathrm{D}-12$ & $5.6266 D+06$ \\
\hline 890 & $4.5394 \mathrm{D}+04$ & $8.2930 \mathrm{D}+01$ & $7.9024 D+C 1$ & 4. $1991 \mathrm{D}-28$ & $1.08010+04$ & $3.1105 D-05$ & $5.2513 \mathrm{D}-12$ & $5.51090-12$ & $5.64430+06$ \\
\hline 900 & $4.6224 D+04$ & $8.3054 D+01$ & $7.90700+01$ & $1.03210-27$ & $1.07980+04$ & $3.12690-05$ & 5. $2577 \mathrm{D}-12$ & $5.5227 \mathrm{D}-12$ & $5.66190+06$ \\
\hline 910 & $4.7055 D+C 4$ & $8.3177 D+01$ & $7.91130+01$ & $2.4871 D-27$ & $1.07940+04$ & $3.14330-05$ & $5.26410-12$ & $5.5345 D-12$ & $5.6794 D+06$ \\
\hline 920 & $4.7887 D+04$ & $8.3238 D+01$ & $7.9154 D+01$ & $5.8799 D-27$ & $1.07910+04$ & $3.15960-05$ & $5.27050-12$ & $5.54650-12$ & $5.6967 \mathrm{D}+06$ \\
\hline 930 & $4.87210+C 4$ & $8.3418 D+01$ & $7.91930+01$ & 1. $3646 D-26$ & $1.07880+04$ & $3.1760 \mathrm{D}-05$ & $5.2770 \mathrm{D}-12$ & $5.5585 D-12$ & $5.7139 \mathrm{D}+06$ \\
\hline 940 & $4.9555 D+04$ & $8.35360+01$ & $7.9230 D+U 1$ & $3.11080-26$ & $9.07840+34$ & $3.1925 \mathrm{D}-05$ & $5.28340-12$ & $5.5706 \mathrm{D}-12$ & $5.73090+06$ \\
\hline 950 & $5.03910+04$ & $8.36530+01$ & $7.9265 D+01$ & $6.9693 \mathrm{D}-26$ & $1.07810+04$ & $3.2089 \mathrm{D}-05$ & $5.2899 D-12$ & $5.5828 \mathrm{D}-12$ & $5.74780+06$ \\
\hline 960 & $5.12290+04$ & $8.3769 D+C 1$ & $7.9297 D+01$ & $1.5354 \mathrm{D}-25$ & $1.07770+04$ & $3.2253 \mathrm{D}-05$ & $5.2964 D-12$ & $5.59510-12$ & $5.76160+06$ \\
\hline 970 & $5.20670+04$ & $9.3884 \mathrm{D}+01$ & $7.932 B D+01$ & $3.32790-25$ & $1.07740+04$ & $3.2418 D-05$ & $5.3029 D-12$ & $5.6075 D-12$ & $5.7812 \mathrm{D}+06$ \\
\hline 980 & $5.2906 \mathrm{D}+0 \mathrm{u}$ & 8. $3998 D+01$ & $7.93570+01$ & $7.1002 \mathrm{D}-25$ & $1.07700+04$ & $3.2583 \mathrm{v}-05$ & $5.3094 D-12$ & $5.6200 \mathrm{D}-12$ & $5.7977 D+06$ \\
\hline 990 & $5.37470+04$ & $8.4111 \mathrm{D}+01$ & $7.93830+01$ & $1.4918 \mathrm{D}-24$ & $1.07670+04$ & $3.2748 D-05$ & $5.3160 D-12$ & $5.6325 D-12$ & $5.81400+06$ \\
\hline 1000 & $5.45890+04$ & $8.42220+n 1$ & $7.9408 D+61$ & $3.08830-24$ & $1.07630+04$ & $3.29130-05$ & $5.3225 D-12$ & $5.6452 \mathrm{D}-12$ & $5.83020+06$ \\
\hline 1010 & $5.54310+04$ & $8.43330+01$ & 7. $9431 D+01$ & $6.3017 D-24$ & $1.07600+34$ & 3. $3078 \mathrm{D}-05$ & $5.32910-12$ & $5.6579 D-12$ & $5.84630+06$ \\
\hline 1020 & $5.6275 D+04$ & $8.4442 \mathrm{D}+01$ & $7.94 .52 \mathrm{D}+01$ & $1.2680 D-23$ & $1.0756 D+04$ & $3.3243 \mathrm{D}-35$ & $5.3357 D-12$ & $5.6708 D-12$ & $5.8622 \mathrm{D}+06$ \\
\hline 1030 & $5.7120 D+C 4$ & $8.4551 \mathrm{D}+\mathrm{C} 1$ & $7.9472 D+01$ & $2.5171 D-23$ & $1.0752 D+04$ & 3. $34090-05$ & $5.3423 D-12$ & $5.6837 D-12$ & $5.87790+06$ \\
\hline 1040 & $5.7966 \mathrm{D}+04$ & $8.4659 D+01$ & $7.94890+01$ & $4.93110-23$ & $1.07490+04$ & 3. $3574 \mathrm{D}-05$ & $5.3489 D-12$ & $5.69670-12$ & $5.8936 \mathrm{D}+06$ \\
\hline 1050 & $5.8813 D+04$ & $8.47660+01$ & 7. $95050+01$ & $9.53740-23$ & $1.07450+04$ & $3.374 \mathrm{JD}-05$ & $5.3555 D-12$ & $5.7099 D-12$ & $5.9091 \mathrm{D}+06$ \\
\hline 1060 & $5.96610+04$ & $8.48720+01$ & $7.95200+01$ & $1.8218 D-22$ & $1.0742 D+C 4$ & $3.39060-05$ & $5.362 .10-12$ & $5.7231 \mathrm{D}-12$ & $5.92440+06$ \\
\hline
\end{tabular}


THEPMODYNAMIC RROPEATIES OF SOLID ORANIUA DIOXIDB

\begin{tabular}{|c|c|c|c|c|c|c|c|c|c|}
\hline $\begin{array}{c}T \\
(R)\end{array}$ & $\begin{array}{l}H-H(298) \\
(J / \text { OOL) }\end{array}$ & $\begin{array}{c}C P \\
(J / M O L-K)\end{array}$ & $\begin{array}{c}\mathrm{CV} \\
(\mathrm{J} / \mathrm{MOL}-K)\end{array}$ & $\stackrel{P}{P}$ & $\begin{array}{c}R E D \\
(K G / L * * 3)\end{array}$ & $\begin{array}{c}\text { ALPHAP } \\
(1 / K)\end{array}$ & $\begin{array}{l}\text { BETAS } \\
(1 / P A)\end{array}$ & $\begin{array}{c}\text { BETAT } \\
(1 / \text { PA) }\end{array}$ & $\begin{array}{l}\text { GAUMAV } \\
\text { (PA/K) }\end{array}$ \\
\hline 1070 & $6.0511 D+04$ & $8.4978 D+01$ & $7.95320+01$ & $3.4382 \mathrm{D}-22$ & $1.0738 D+04$ & $3.4072 D-05$ & $5.3688 D-12$ & $5.7364 D-12$ & $5.93960+06$ \\
\hline 1480 & $6.1361 D+04$ & $8.5082 \mathrm{D}+01$ & $7.95430+01$ & $6.4128 D-22$ & $1.0734 \mathrm{D}+04$ & $3.4238 D-05$ & $5.3755 D-12$ & $5.7498 \mathrm{D}-12$ & $5.95470+06$ \\
\hline 1090 & $6.22120+04$ & $8.5186 \mathrm{D}+01$ & $7.9553 D+01$ & $1.18250-21$ & $1.07310+04$ & $3.4405 \mathrm{D}-05$ & $5.3822 \mathrm{D}-12$ & $5.7633 \mathrm{D}-12$ & $5.9696 \mathrm{D}+06$ \\
\hline 1100 & $6.30650+04$ & $8.52890+01$ & $7.95610+01$ & 2. $1563 \mathrm{D}-21$ & $1.0727 D+04$ & $3.4571 \mathrm{D}-05$ & $5.3889 D-12$ & $5.7769 D-12$ & $5.98430+06$ \\
\hline 1110 & $6.391 B D+C 4$ & $8.5392 D+01$ & $7.9567 D+01$ & $3.8898 D-21$ & $1.07230+04$ & $3.47380-05$ & $5.3956 \mathrm{D}-12$ & $5.7906 \mathrm{D}-12$ & $5.99890+06$ \\
\hline 1120 & $6.4773 D+04$ & $8.5494 D+01$ & $7.9572 D+01$ & $6.9434 \mathrm{D}-21$ & $1.0719 \mathrm{D}+04$ & $3.4905 \mathrm{D}-05$ & $5.4024 D-12$ & $5.8044 \mathrm{D}-12$ & $6.0134 D+06$ \\
\hline 1130 & $6.56280+04$ & $8.5595 D+01$ & $7.9576 \mathrm{D}+01$ & 1. $22268 D-20$ & $1.07160+04$ & $3.5071 \mathrm{D}-05$ & $5.4092 D-12$ & $5.8183 \mathrm{D}-12$ & $6.0277 D+06$ \\
\hline 1140 & $6.6484 D+04$ & $8.5696 \mathrm{D}+01$ & $7.95780+01$ & $2.14590-20$ & $1.07120+04$ & $3.5239 D-05$ & $5.4159 \mathrm{D}-12$ & $5.8324 D-12$ & $6.04190+06$ \\
\hline 1150 & $6.7342 D+04$ & $8.5797 D+01$ & $7.9578 D+01$ & $3.7174 \mathrm{D}-20$ & $1.07080+04$ & $3.5406 \mathrm{D}-05$ & $5.4227 D-12$ & $5.84650-12$ & $6.05590+06$ \\
\hline 1160 & $6.82000+04$ & $8.5896 D+01$ & $7.9578 D+01$ & $6.3790 \mathrm{D}-20$ & $1.0704 D+04$ & $3.5573 D-05$ & $5.42960-12$ & $5.96070-12$ & $6.06980+06$ \\
\hline 1170 & $6.90600+04$ & $8.59960+01$ & $7.9576 \mathrm{D}+01$ & $1.0846 \mathrm{D}-19$ & $1.07000+04$ & $3.5741 D-05$ & $5.43640-12$ & $5.8750 D-12$ & $6.0836 \mathrm{D}+06$ \\
\hline 1180 & $6.99200+04$ & $8.60940+01$ & $7.9573 D+01$ & $1.82750-19$ & $1.0697 D+24$ & $3.5908 D-05$ & $5.4432 D-12$ & $5.88340-12$ & $6.0971 \mathrm{D}+06$ \\
\hline 1190 & $7.0782 \mathrm{D}+04$ & e.6193D+01 & $7.9568 D+01$ & $3.0524 D-19$ & $1.0693 \mathrm{D}+04$ & $3.6076 D-05$ & $5.4501 D-12$ & $5.9039 D-12$ & $6.1106 D+06$ \\
\hline 1200 & $7.1 \in 44 D+04$ & e. $6291 \mathrm{D}+01$ & $7.95620+01$ & $5.0549 \mathrm{D}-19$ & $1.0689 D+04$ & $3.6244 \mathrm{D}-05$ & $5.4570 \mathrm{D}-12$ & $5.91850-12$ & 6. $12390+06$ \\
\hline 1210 & $7.25080+04$ & e. $63880+C 1$ & $7.95550+01$ & $8.3018 D-19$ & $1.06850+04$ & $3.6412 \mathrm{D}-05$ & $5.4639 D-12$ & $5.9332 D-12$ & $6.137 \mathrm{CD}+06$ \\
\hline 1229 & $7.3372 D+C 4$ & $8.64850+01$ & $7.9547 \mathrm{D}+01$ & $1.3524 \mathrm{D}-18$ & $1.0681 \mathrm{D}+04$ & $3.65800-05$ & $5.4708 \mathrm{D}-12$ & $5.94800-12$ & $6.15000+06$ \\
\hline 1230 & $7.42370+04$ & $8.6582 D+01$ & $7.95370+01$ & $2.1856 D-18$ & $1.0677 D+04$ & $3.6749 \mathrm{D}-\mathrm{U} 5$ & $5.4778 D-12$ & $5.9630 D-12$ & $6.16290+06$ \\
\hline 1240 & $7.51040+04$ & $8.6679 \mathrm{D}+01$ & $7.95270+01$ & $3.5050 D-18$ & $1.06730+04$ & $3.6917 \mathrm{D}-05$ & $5.4847 \mathrm{D}-12$ & $5.9780 D-12$ & $6.1755 D+06$ \\
\hline 1250 & $7.59710+04$ & $8.67750+01$ & $7.95150+01$ & $5.5785 D-18$ & $1.0669 D+04$ & $3.70860-05$ & $5.4917 \mathrm{D}-12$ & $5.99310-12$ & $6.18810+06$ \\
\hline 1260 & $7.68390+04$ & $8.68710+01$ & $7.9502 D+01$ & $8.8134 D-18$ & $1.06650+04$ & $3.7255 \mathrm{D}-05$ & $5.4987 \mathrm{D}-12$ & $6.0084 D-12$ & $6.20050+06$ \\
\hline 1270 & $7.77080+04$ & $8.6967 D+01$ & $7.94880+01$ & $1.3824 \mathrm{D}-17$ & $1.06610+34$ & $3.7424 D-05$ & $5.5 C 57 D-12$ & $6.02370-12$ & $6.2127 D+06$ \\
\hline 1280 & $7.85760+04$ & $2.7063 D+01$ & $7.9473 \mathrm{D}+01$ & $2.1532 \mathrm{D}-17$ & $1.0657 D+J 4$ & $3.75930-05$ & $5.51270-12$ & $6.03920-12$ & $6.22480+06$ \\
\hline 1290 & $7.9449 \mathrm{D}+04$ & $8.71580+01$ & $7.9457 D+01$ & $3.3308 D-17$ & $1.0653 D+04$ & $3.7762 \mathrm{D}-05$ & $5.51980-12$ & $6.05470-12$ & $6.2368 D+06$ \\
\hline 1300 & $8.0322 \mathrm{D}+04$ & $8.7254 \mathrm{D}+01$ & $7.9441 \mathrm{D}+01$ & $5.1180 D-17$ & $1.0649 D+04$ & $3.7931 \mathrm{D}-05$ & $5.5268 D-12$ & $6.0704 \mathrm{D}-12$ & $6.24860+96$ \\
\hline 1310 & $8.11950+04$ & $8.7349 D+01$ & $7.94230+01$ & $7.8127 \mathrm{D}-17$ & $1.0645 \mathrm{D}+04$ & $3.8101 \mathrm{D}-05$ & $5.5339 D-12$ & $6.38620-12$ & $6.26020+06$ \\
\hline 1320 & $\varepsilon .2069 D+04$ & $8.7444 D+01$ & $7.9404 D+01$ & $1.1850 D-16$ & $1.06410+04$ & $3.82700-05$ & 5.541 JD -12 & $6.10210-12$ & $6.27170+06$ \\
\hline
\end{tabular}


THEF MODYNAMIC PROPEETIES OF SOLID ORANIOM DIOXIDE

\begin{tabular}{|c|c|c|c|c|c|c|c|c|c|}
\hline $\begin{array}{c}T \\
(k)\end{array}$ & $\begin{array}{l}B-H(298) \\
(J / H O L)\end{array}$ & $\begin{array}{c}C P \\
(\mathrm{~J} / \mathrm{MOL}-\mathrm{K})\end{array}$ & $\begin{array}{c}C V \\
(J / M O L-K)\end{array}$ & $\underset{(\triangle P A)}{P}$ & $\begin{array}{c}\text { RHO } \\
(K G / 3 * * 3)\end{array}$ & $\begin{array}{c}\text { A LPHAP } \\
(1 / K)\end{array}$ & $\begin{array}{l}\text { BETAS } \\
(1 / P A)\end{array}$ & $\begin{array}{l}\text { BЕTAT: } \\
(1 / \mathrm{PA})\end{array}$ & $\begin{array}{l}\text { GAMBAV } \\
\text { (PA/R) }\end{array}$ \\
\hline 1330 & $8.29430+04$ & $9.75390+01$ & $7.9385 D+01$ & $1.78610-16$ & $1.0637 D+34$ & 3. $94400-05$ & $5.54810-12$ & $6.11800-12$ & $6.28310+0$ \\
\hline 1540 & E. $38190+04$ & $8.76350+01$ & $7.9365 D+01$ & $2.6758 \mathrm{D}-16$ & $1.06330+04$ & $3.86100-05$ & $5.5553 \mathrm{D}-12$ & $6.1341 \mathrm{D}-12$ & $6.2943 D+0$ \\
\hline 1350 & e. $46960+04$ & $8.77300+01$ & $7.9344 \mathrm{D}+01$ & 3. $984 \in D-16$ & $1.0629 D+04$ & $3.8780 \mathrm{D}-05$ & $5.56240-12$ & $6.1504 D-12$ & $6.30540+0$ \\
\hline 1360 & E. 5574D+04 & $8.7826 \mathrm{D}+01$ & $7.9322 \mathrm{D}+01$ & $5.89900-16$ & $1.06240+34$ & $3.8950 \mathrm{D}-05$ & $5.5696 \mathrm{D}-12$ & $6.1667 D-12$ & $6.31630+0$ \\
\hline 1370 & $8.6453 D+04$ & $8.7921 D+01$ & $7.93000+01$ & $8.6832 \mathrm{D}-16$ & $1.06200+04$ & $3.91210-05$ & $5.5768 D-12$ & $6.18+10-12$ & $6.32700 \bullet 0$ \\
\hline 1380 & E. $7332 D+04$ & $8.8017 D+01$ & $7.9277 D+01$ & $1.2710 \mathrm{D}-15$ & $1.06160+04$ & $3.92910-05$ & $5.5840 \mathrm{D}-12$ & $6.19970-12$ & $6.3376 D+06$ \\
\hline 1390 & e. $82130+04$ & $8.81130+01$ & $7.9253 \mathrm{D}+01$ & $1.8503 D-15$ & $1.06120+04$ & $3.94620-05$ & $5.5912 \mathrm{D}-12$ & $6.2163 D-12$ & $6.34810+0$ \\
\hline 1400 & E. $9095 D+04$ & $8.8210 D+01$ & $7.9220 D+01$ & $2.6792 \mathrm{D}-15$ & $1.06080+04$ & $3.96320-05$ & $5.59850-12$ & $6.23310-12$ & $6.3584 \mathrm{D}+0$ \\
\hline 1410 & $8.9977 D+04$ & $8.8307 D+01$ & 7. $9205 \mathrm{D}+01$ & $3.85910-15$ & $1.06040+134$ & $3.98030-05$ & $5.6057 D-12$ & $6.2499 \mathrm{D}-12$ & $6.36860+0$ \\
\hline 1420 & $9.0861 D+04$ & $8.84040+01$ & $7.9180 D+01$ & $5.53010-15$ & $1.05990+04$ & $3.99740-05$ & $5.6130 \mathrm{D}-12$ & $6.2669 D-12$ & $6.3786 \mathrm{D}+06$ \\
\hline 1430 & $9.1745 D+04$ & $8.8502 D+01$ & $7.91550+01$ & $7.8849 D-15$ & $1.0595 D+04$ & $4.01450-05$ & $5.62030-12$ & $6.2840 \mathrm{D}-12$ & $6.3885 D+06$ \\
\hline 1440 & $9.2631 \mathrm{C}+04$ & $8.8600 D+01$ & $7.9129 D+01$ & $1.1187 D-14$ & $1.05910+04$ & $4.0317 \mathrm{D}-05$ & $5.6276 D-12$ & $6.3012 D-12$ & $6.39820+06$ \\
\hline $145 \mathrm{C}$ & $S, 3517 D+04$ & $8.8699 D+01$ & $7.9104 \mathrm{D}+01$ & $1.5796 \mathrm{D}-14$ & $1.0586 D+04$ & $4.04880-05$ & $5.6350 D-12$ & $6.3185 D-12$ & $6.4078 D+06$ \\
\hline 1460 & $5.4405 D+04$ & $8.8799 \mathrm{D}+01$ & $7.9078 D+01$ & $2.219 B D-14$ & $1.0582 D+04$ & $4.06600-05$ & $5.6423 \mathrm{D}-12$ & $6.3359 D-12$ & $6.4173 D+06$ \\
\hline 1470 & $5.52930+04$ & $8.8899 \mathrm{D}+01$ & 7. $9052 D+01$ & 3. $1052 D-14$ & $1.05780+24$ & $4.08310-05$ & $5.6497 D-12$ & $6.3535 D-12$ & $6.4266 \mathrm{D}+06$ \\
\hline 1480 & $9.61830+04$ & $8.90000+01$ & $7.90260+01$ & $4.32390-14$ & $1.0573 D+04$ & $4.1003 D-05$ & $5.6571 \mathrm{D}-12$ & $6.37110-12$ & $6.4358 D+06$ \\
\hline 1490 & $9.7073 D+C 4$ & $8.9103 D+01$ & $7.90010+01$ & $5.9944 D-14$ & $1.0569 D+04$ & 4. $1175 D-05$ & $5.6645 D-12$ & $6.3889 D-12$ & $6.4448 D+06$ \\
\hline 1500 & $9.79650+04$ & $8.92060+01$ & $7.8975 D+C 1$ & $8.2740 \mathrm{CD}-14$ & $1.0565 D+04$ & $4.13470-05$ & $5.6720 D-12$ & $6.4067 D-12$ & $6.4537 D+06$ \\
\hline 1510 & $9.88570+04$ & $8.93100+01$ & $7.8950 D+01$ & $1.1372 \mathrm{D}-13$ & $1.05600+04$ & $4.1519 D-05$ & $5.6794 \mathrm{D}-12$ & $6.4247 D-12$ & $6.46240+06$ \\
\hline 1520 & $9.97510+C 4$ & $8.9415 D+01$ & $7.8925 \mathrm{D}+01$ & $1.5565 D-13$ & $1.05560+04$ & $4.1691 \mathrm{D}-05$ & $5.6869 \mathrm{D}-12$ & $6.4428 D-12$ & $6.47100+06$ \\
\hline 1530 & $1.00650+05$ & $9.9522 \mathrm{D}+01$ & $7.89010+01$ & $2.1216 D-13$ & $1.0552 D+34$ & $4.1864 D-05$ & $5.6944 \mathrm{D}-12$ & $6.4610 D-12$ & $6.47950+06$ \\
\hline 1540 & $1.01540+05$ & $8.96300+01$ & $7.8877 D+01$ & $2.88030-13$ & $1.05470+04$ & $4.20 .37 \mathrm{D}-05$ & $5.7019 D-12$ & $6.4793 \mathrm{D}-12$ & $6.4879 D+G 6$ \\
\hline 1550 & $1.0244 D+05$ & $8.97400+01$ & 7. $8854 D+01$ & $3.8949 D-13$ & $1.0543 D+04$ & $4.2209 D-05$ & $5.70950-12$ & $6.4976 D-12$ & $6.49610+06$ \\
\hline $156 \mathrm{C}$ & $1.0334 \mathrm{D}+05$ & $8.98510+01$ & $7.8832 D+01$ & $5.24650-13$ & $1.0538 D+04$ & $4.23820-05$ & $5.71700-12$ & $6.51610-12$ & $6.5042 D+06$ \\
\hline 1570 & $1.04240+05$ & $8.9963 D+01$ & $7.88100+01$ & $7.04050-13$ & $1.0534 D+04$ & $4.2555 \mathrm{D}-0.05$ & $5.7246 D-12$ & $6.5348 D-12$ & $6.5121 D+06$ \\
\hline 1580 & $1.05140+05$ & $9.0078 D+01$ & $7.87890+01$ & $9.4128 D-13$ & $1.05290+34$ & $4.27280-05$ & $5.73220-12$ & $6.55350-12$ & $6.51990+06$ \\
\hline
\end{tabular}


THFRMODYARIC PROPEETIES OF SOLID ORARIUU DIOXIDE

\begin{tabular}{|c|c|c|c|c|c|c|c|c|c|}
\hline$\stackrel{T}{(R)}$ & $\begin{array}{l}\mathrm{A}-\mathrm{B}(298) \\
(\mathrm{J} / \mathrm{BOL})\end{array}$ & $\begin{array}{c}C P \\
(\mathrm{~N} / \mathrm{HOL}-\mathrm{K})\end{array}$ & $\begin{array}{c}C V \\
(J / \text { MOL }-K)\end{array}$ & $\begin{array}{c}P \\
(B P A)\end{array}$ & 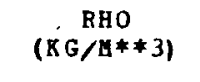 & $\begin{array}{c}\text { A LPBAP } \\
(1 / K)\end{array}$ & $\begin{array}{l}\text { BETAS } \\
(1 / P A)\end{array}$ & $\begin{array}{r}\text { BETAT } \\
\text { (1/PA) }\end{array}$ & $\begin{array}{l}\text { GAMHAY } \\
(\mathrm{PA} / \mathrm{K})\end{array}$ \\
\hline 1590 & $1.0604 D+05$ & $9.01940+01$ & $7.87700+01$ & $1.2538 D-12$ & $1.0525 D+04$ & $4.2901 \mathrm{D}-05$ & $5.73980-12$ & $6.5723 D-12$ & $6.5276 \mathrm{D}+06$ \\
\hline 1600 & 1. CE94D+05 & $9.0312 D+01$ & $7.8752 \mathrm{D}+01$ & $1.6642 D-12$ & $1.35200+04$ & $4.3075 D-05$ & $5.7475 D-12$ & $6.5912 \mathrm{D}-12$ & $6.5352 \mathrm{D}+06$ \\
\hline 1610 & $1.0784 D+05$ & $9.04330+01$ & & $2.2012 \mathrm{D}-12$ & $1.05160+04$ & $4.32480-05$ & & & \\
\hline 1620 & $1.0875 D+05$ & $9.0556 \mathrm{D}+01$ & & $2.90140-12$ & $1.0511 D+04$ & $4.34220-05$ & & & \\
\hline $163 \mathrm{C}$ & $1.0965 D+05$ & $9.06810+01$ & & $3.8113 D-12$ & $1.0506 \mathrm{D}+04$ & $4.35950-05$ & & & \\
\hline 1640 & 1. $1056 D+05$ & $9.08090+01$ & & $4.99010-12$ & $1.0502 D+04$ & $4.3769 D-05$ & & & \\
\hline 1650 & $1.1147 D+05$ & $9.09390+01$ & & $6.5120 \mathrm{D}-12$ & $1.0497 D+04$ & 4. $3943 D-05$ & & & \\
\hline 1660 & $1.1238 D+05$ & $9.1072 D+01$ & & $8.47100-12$ & $1.04930+04$ & $4.4117 D-0.5$ & & & \\
\hline $167 \mathrm{C}$ & $1.1329 D+05$ & $9.12090+01$ & & $1.0985 D-11$ & $1.04880+04$ & $4.42920-05$ & & & \\
\hline 1680 & $1.14200+05$ & $9.1348 D+01$ & & $1.4200 D-11$ & $1.04830+04$ & $4.44660-05$ & & & \\
\hline 1690 & $1.1512 D+05$ & $9.14910+01$ & & $1.83010-11$ & $1.04790+04$ & $4.4640 D-05$ & & & \\
\hline $170 \mathrm{C}$ & $1.16030+05$ & $9.1637 D+01$ & & $2.3516 D-11$ & $1.04740+04$ & 4. $4815 \mathrm{D}-05$ & & & \\
\hline 1710 & $1.16950+05$ & $9.1787 D+01$ & & $3.0129 D-11$ & $1.0469 D+C 4$ & $.4 .4990 D-05$ & & & \\
\hline 1720 & $1.1787 D+05$ & $9.1941 D+01$ & & $3.8490 D-11$ & $1.04640+04$ & $4.51640-05$ & & & \\
\hline 1730 & $1.18790+05$ & $9.20900+01$ & & $4.9032 D-11$ & $1.0460 D+04$ & $4.53390-05$ & & & \\
\hline 1740 & $1.19710+05$ & $9.2260 \mathrm{D}+01$ & & $6.2288 D-11$ & $1.0455 D+04$ & $4.5514 D-05$ & & & \\
\hline 1750 & $1.20640+05$ & $9.2426 D+01$ & & $7.8912 \mathrm{D}-11$ & $1.04500+04$ & $4.5590 D-05$ & & & \\
\hline 1760 & $1.2156 D+0.5$ & $9.2597 D+01$ & & $9.9705 D-11$ & $1.0445 D+04$ & $4.5865 \mathrm{D}-05$ & & & \\
\hline 1770 & $1.22490+05$ & $9.27730+01$ & & $1.256+0-10$ & $1.0441 \mathrm{D}+04$ & $4.60400-05$ & & & \\
\hline 1780 & $1.2342 D+05$ & $9.2953 \mathrm{D}+01$ & & $1.5792 \mathrm{D}-10$ & $1.0436 D+04$ & $4.6216 \mathrm{D}-05$ & & & \\
\hline 1790 & $1.2435 D+05$ & $9.3139 D+01$ & & $1.9798 D-10$ & $1.04310+04$ & $4.6392 \mathrm{D}-05$ & & & \\
\hline 1800 & 1. $2528 D+05$ & $9.33310+01$ & & $2.4758 D-10$ & $1.04260+04$ & $4.6567 \mathrm{D}-05$ & & & \\
\hline 1810 & $1.2621 \mathrm{D}+05$ & $9.352 .7 D+C 1$ & & $3.0884 \mathrm{D}-10$ & $1.04210+04$ & $4.67430-05$ & & & \\
\hline 1820 & $1.2715 D+C 5$ & $9.37300+01$ & & $3.84330-10$ & $1.0416 \mathrm{D}+04$ & $4.69190-05$ & & & \\
\hline 1830 & $1.2809 D+05$ & $9.3939 D+01$ & & $4.7713 D-10$ & $1.04110+04$ & $4.70960-05$ & & & \\
\hline $1 \varepsilon 40$ & $1.2903 D+05$ & $9.4154 D+C 1$ & & $5.9094 \mathrm{D}-10$ & $1.04060+04$ & $4.7272 D-05$ & & & \\
\hline
\end{tabular}


THFRMODYNAGIC PEOPERT IES OF SULTD URANIUM DIOXIDE

\begin{tabular}{|c|c|c|c|c|c|c|c|c|c|}
\hline$\frac{T}{(K)}$ & $\begin{array}{c}H-H(298) \\
(J / A O L)\end{array}$ & $\begin{array}{c}C P \\
(J / H O L-K)\end{array}$ & $\begin{array}{c}\text { CV } \\
(J / \text { HOL }-K)\end{array}$ & $\begin{array}{c}P \\
(X E A)\end{array}$ & $\begin{array}{c}\mathrm{HHO} \\
(\mathrm{KG} / \mathrm{H} * * 3)\end{array}$ & $\begin{array}{c}\text { A LPEAP } \\
(1 / K)\end{array}$ & $\begin{array}{l}\text { GETAS } \\
(1 / P A)\end{array}$ & $\begin{array}{r}\text { BETAT } \\
(1 / \mathrm{PA})\end{array}$ & $\begin{array}{l}\text { GAMHAV } \\
(\mathrm{PA} / \mathrm{K})\end{array}$ \\
\hline 1850 & $1.2997 D+05$ & $9.4376 D+01$ & & $7.3021 \mathrm{D}-10$ & $1.04010+04$ & $4.7448 D-D 5$ & & & \\
\hline 1860 & $1.3092 \mathrm{D}+05$ & $9.4605 D+01$ & & $9.0025 \mathrm{D}-10$ & $1.03970+04$ & $4.7625 \mathrm{D}-05$ & & & \\
\hline 1870 & $1.3186 D+05$ & $9.48410+01$ & & $1.1074 \mathrm{D}-09$ & $1.0392 \mathrm{D}+04$ & $4.78010-05$ & & & \\
\hline 1880 & $1.3281 D+05$ & $9.50840+01$ & & $1.3592 \mathrm{D}-09$ & $1.0387 \mathrm{D}+04$ & $4.79780-05$ & & & \\
\hline 1890 & $1.3376 D+05$ & $9.5334 \mathrm{D}+01$ & & $1.6647 D-09$ & $1.0382 D+04$ & $4.81550-05$ & & & \\
\hline 1900 & $1.3472 D+05$ & $9.5593 \mathrm{D}+01$ & & $2.0345 D-09$ & $1.03770+04$ & $4.8332 \mathrm{D}-05$ & & & \\
\hline 1910 & $1.3568 D+05$ & $9.5860 \mathrm{D}+01$ & & $2.4812 \mathrm{D}-09$ & $1.0372 D+04$ & $4.8509 D-05$ & & & \\
\hline 1920 & $1.3664 D+05$ & $9.6135 D+01$ & & $3.0197 \mathrm{D}-09$ & $1.0366 \mathrm{D}+\mathrm{C4}$ & $4.8686 \mathrm{D}-05$ & & & \\
\hline 19.30 & $1.37600+05$ & $9.6419 \mathrm{D}+01$ & & $3.6677 D-09$ & $1.0361 \mathrm{D}+04$ & $4.88640-05$ & & & \\
\hline 1940 & $1.3857 \mathrm{D}+05$ & $9.67120+01$ & & $4.4457 D-09$ & $1.03560+04$ & $4.9041 \mathrm{D}-05$ & & & \\
\hline 1950 & $1.3953 D+C 5$ & $9.7014 D+01$ & & $5.3782 \mathrm{D}-09$ & $1.03510+04$ & $4.9218 D-05$ & & & \\
\hline 1960 & $1.40510+05$ & $9.7326 \mathrm{D}+01$ & & $6.4937 D-09$ & $1.03460+04$ & $4.9396 \mathrm{D}-05$ & & & \\
\hline 1970 & $1.41480+05$ & $9.7648 D+01$ & & $7.8255 D-09$ & $1.03410+04$ & $4.95740-05$ & & & \\
\hline 1980 & $1.4246 D+05$ & $9.7980 D+01$ & & $9.4128 D-09$ & $1.0336 D+04$ & $4.9752 \mathrm{D}-05$ & & & \\
\hline 1990 & $1.4344 D+05$ & $9.8322 \mathrm{D}+01$ & & $1.13010-08$ & $1.03310+04$ & $4.9930 \mathrm{D}-05$ & & & \\
\hline 2000 & $1.4442 \mathrm{D}+05$ & $9.8675 E+21$ & & $1.3543 D-08$ & $1.0326 D+04$ & $5.010 B D-05$ & & & \\
\hline 2010 & $1.45410+C 5$ & $9.9040 D+01$ & & $1.62010-08$ & $1.03200+04$ & $5.02860-05$ & & & \\
\hline 2020 & $1.4641 \mathrm{D}+05$ & $9.9416 \mathrm{D}+01$ & & $1.9346 D-08$ & $1.03150+34$ & $5.04640-05$ & & & \\
\hline $203 C$ & $1.47400+05$ & $9.9804 \mathrm{D}+01$ & & $2.3061 \mathrm{D}-08$ & $1.03100+94$ & $5.0643 \mathrm{D}-05$ & & & \\
\hline 2040 & $1.48400+05$ & $1.00200+02$ & & $2.7442 D-08$ & $1.03050+04$ & $5.08210-05$ & & & \\
\hline 2050 & $1.49410+05$ & $1.00620+02$ & & $3.26010-08$ & $1.0299 D+04$ & $5.10000-05$ & & & \\
\hline 2060 & $1.56410+05$ & $1.0104 \mathrm{D}+02$ & & $3.8664 \mathrm{D}-08$ & $1.02940+04$ & $5.1179 D-05$ & & & \\
\hline 2070 & $1.5143 \mathrm{D}+05$ & $1.0148 D+02$ & & $4.578 C D-08$ & $1.0289 D+04$ & $5.13580-05$ & & & \\
\hline 2080 & $1.5244 D+05$ & $1.0193 \mathrm{D}+02$ & & $5.41170-08$ & $1.0284 \mathrm{D}+04$ & $5.1537 D-05$ & & & \\
\hline $209 \mathrm{C}$ & $1.5347 D+05$ & $1.0240 \mathrm{D}+02$ & & $6.387 C D-08$ & $1.0278 D+04$ & $5.1716 D-05$ & & & \\
\hline 2100 & $1.5449 D+05$ & $1.02880+02$ & & $7.5262 D-08$ & $1.02730+04$ & $5.1895 D-05$ & & & \\
\hline
\end{tabular}


THERLODYNAMIC PROPERTIES OF SOLID URANIUM DIOXIDE

\begin{tabular}{|c|c|c|c|c|c|c|}
\hline $\begin{array}{c}T \\
(K)\end{array}$ & $\begin{array}{l}\mathrm{B}-\mathrm{H}(2.98) \\
(\mathrm{J} / \mathrm{MOL})\end{array}$ & $\begin{array}{c}\text { CP } \\
(J / H O I-K)\end{array}$ & $\begin{array}{c}C V \\
(J / 4 O L-K)\end{array}$ & $\begin{array}{c}P \\
(M P A)\end{array}$ & 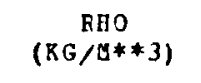 & $\begin{array}{c}\text { AL P E AP } \\
(1 / K)\end{array}$ \\
\hline 2110 & $1.5552 \mathrm{D}+05$ & $1.0337 D+02$ & & $8.8548 D-08$ & $1.0268 D+04$ & $5.2074 \mathrm{D}-05$ \\
\hline 2120 & 1. $5 \in 56 D+0.5$ & $1.0388 D+02$ & & $1.0402 \mathrm{D}-\mathrm{C} .7$ & $1.0262 D+174$ & $5.2253 D-05$ \\
\hline 2130 & $1.57600+05$ & $1.04410+02$ & & $1.22010-07$ & $1.0257 D+04$ & $5.24330-05$ \\
\hline 2140 & 1. $5 e 650+05$ & $1.04950+02$ & & $1.42900-07$ & $1.0252 \mathrm{D}+04$ & $5.2613 D-05$ \\
\hline 2150 & $1.59700+05$ & $1.05500+02$ & & $1.6712 \mathrm{D}-07$ & $1.0246 D+04$ & $5.2792 \mathrm{D}-05$ \\
\hline 2160 & $1.60760+05$ & $1.06070+02$ & & $1.9516 \mathrm{D}-07$ & $1.02410+04$ & $5.29720-05$ \\
\hline 2170 & $1.6182 D+05$ & $1.0666 \mathrm{D}+02$ & & $2.27580-07$ & $1.0235 D+04$ & $5.31520-05$ \\
\hline 2180 & $1.6289 D+05$ & $1.0727 \mathrm{D}+02$ & & $2.65010-07$ & $1.0230 D+04$ & $5.3332 \mathrm{D}-05$ \\
\hline 2190 & $1.6397 D+05$ & $1.0790 D+02$ & & $3.0817 \mathrm{D}-07$ & $1.02240+04$ & $5.3512 \mathrm{D}-05$ \\
\hline 2200 & $1.6505 D+05$ & $1.08540+02$ & & $3.5786 \mathrm{D}-07$ & $1.02190+04$ & $5.36920-05$ \\
\hline 2210 & $1.66140+05$ & $1.09200+02$ & & $4.15010-07$ & $1.02130+34$ & $5.3873 \mathrm{D}-05$ \\
\hline 2220 & $1.67230+05$ & $1.0988 D+02$ & & $4.8065 \mathrm{D}-07$ & $1.0208 D+04$ & $5.40530-05$ \\
\hline 2230 & $1.68340+05$ & $1.1058 D+02$ & & $5.55930-07$ & $1.0202 D+04$ & $5.4234 \mathrm{D}-05$ \\
\hline $224 \mathrm{C}$ & $1.6944 D+05$ & $1.1129 D+02$ & & $6.4216 D-07$ & $1.0197 D+04$ & $5.4414 \mathrm{D}-05$ \\
\hline 2250 & $1.7056 D+C 5$ & $1.12030+02$ & & $7.40830-07$ & $1.01910+04$ & $5.45950-05$ \\
\hline 2260 & $1.7169 D+05$ & $1.1279 \mathrm{D}+02$ & & $8.53570-07$ & $1.018 \dot{0} D+04$ & $5.47776 \mathrm{D}-05$ \\
\hline 2270 & $1.7282 D+05$ & $1.13570+02$ & & $9.8224 D-07$ & $1.01800+04$ & $5.49570-05$ \\
\hline 2280 & $1.73960+05$ & $1.1437 \mathrm{D}+02$ & & $1.1289 \mathrm{D}-06$ & $1.0174 D+04$ & $5.5138 D-05$ \\
\hline 2290 & $1.75100+0.5$ & $1.1519 D+02$ & & $1.29590-06$ & $1.0169 D+04$ & $5.5319 D-05$ \\
\hline 2300 & $1.7626 D+05$ & $1.1603 D+02$ & & $1.48590-06$ & $1.01630+04$ & $5.55000-05$ \\
\hline 2310 & $1.7743 \mathrm{D}+05$ & $1.16900+02$ & & $1.7016 \mathrm{D}-06$ & $1.0158 D+04$ & $5.56810-0.5$ \\
\hline 2320 & $1.78690+05$ & $1.17790+02$ & & $1.94640-06$ & $1.0152 D+04$ & $5.5863 D-05$ \\
\hline 2330 & $1.7578 D+05$ & $1.18700+02$ & & $2.2239 D-C 6$ & $1.0146 \mathrm{D}+04$ & $5.6044 D-05$ \\
\hline 2340 & $1.80970+05$ & $1.19630+02$ & & $2.538 C D-06$ & $1.01410+04$ & $5.6226 \mathrm{D}-05$ \\
\hline 2350 & $1.82170+05$ & $1.2059 D+02$ & & $2.8932 \mathrm{D}-06$ & $1.0135 \mathrm{D}+34$ & $5.64080-05$ \\
\hline 2360 & $1.8338 D+05$ & $1.2158 \mathrm{D}+02$ & & $3.2945 \mathrm{D}-06$ & $1.01290+04$ & $5.6589 D-05$ \\
\hline
\end{tabular}


THERGODYNAMIC PROPERTIES OF SOLID URANIUY DIOXIDE

\begin{tabular}{|c|c|c|c|c|c|c|}
\hline $\begin{array}{c}T \\
(K)\end{array}$ & $\begin{array}{l}H-4(298) \\
(J / 4 O L)\end{array}$ & $\begin{array}{c}C P \\
(J / K O L-K)\end{array}$ & $\begin{array}{c}C V \\
(J / Y O L-K)\end{array}$ & $\stackrel{P}{(\triangle P A)}$ & $\begin{array}{c}\text { RHO } \\
(K G / A * * 3)\end{array}$ & $\begin{array}{c}\text { ALPHAF } \\
(1 / K)\end{array}$ \\
\hline 2370 & $1.84610+05$ & $1.2258 D+02$ & & $3.74730-06$ & $1.0123 D+24$ & $5.67710-05$ \\
\hline 2380 & 1. $8584 D+05$ & $1.2362 D+02$ & & $4.2577 \mathrm{D}-06$ & $1.01180+04$ & $5.6953 D-05$ \\
\hline 2390 & $1.8708 D+05$ & $1.24680+02$ & & $4.8326 \mathrm{D}-06$ & $1.01120+04$ & $5.7135 D-05$ \\
\hline 2400 & $1.88330+05$ & $1.2576 \mathrm{D}+02$ & & $5.47920-06$ & $1.0106 \mathrm{D}+04$ & $5.7318 D-05$ \\
\hline 2410 & $1.8 \subseteq 59 D+05$ & $1.2687 \mathrm{D}+02$ & & $6.2059 \mathrm{D}-06$ & $1.01000+04$ & $5.7500 \mathrm{D}-05$ \\
\hline 2420 & $1.9087 D+C 5$ & $1.2801 \mathrm{D}+C 2$ & & $7.0217 \mathrm{D}-06$ & 1. $00940+04$ & $5.7682 D-05$ \\
\hline 2430 & $1.92150+05$ & $1.29180+02$ & & $7.93670-06$ & $1.00890+04$ & $5.7865 D-05$ \\
\hline 2440 & $1.9345 D+05$ & $1.3037 D+02$ & & $8.96200-06$ & $1.0083 D+04$ & $5.80470-05$ \\
\hline 2450 & $1.9476 D+05$ & $1.3159 D+02$ & & $1.01100-05$ & $1.0077 \mathrm{D}+04$ & $5.82300-05$ \\
\hline 2460 & $1.9608 D+05$ & $1.3284 \mathrm{D}+02$ & & 1. $1393 \mathrm{D}-05$ & $1.00710+04$ & $5.8413 D-05$ \\
\hline 2470 & $1.9742 \mathrm{D}+05$ & $1.3412 \mathrm{D}+02$ & & $1.2827 \mathrm{D}-05$ & $1.00650+04$ & $5.8595 \mathrm{D}-05$ \\
\hline 2480 & $1.9877 D+05$ & $1.3543 \mathrm{D}+\mathrm{C} 2$ & & $1.4428 \mathrm{D}-05$ & $1.0059 D+04$ & $5.8778 D-05$ \\
\hline 2490 & $2.00130+05$ & $1.3677 \mathrm{D}+02$ & & $1 . \in 213 D-05$ & $1.00530+04$ & $5.89610-05$ \\
\hline 2500 & $2.0150 D+05$ & $1.3814 D+02$ & & $1.8202 \mathrm{D}-05$ & $1.00470+04$ & $5.3144 D-05$ \\
\hline 2510 & $2.0289 D+05$ & $1.3953 D+02$ & & $2.04160-05$ & $1.00410+04$ & $5.9328 D-05$ \\
\hline 2520 & $2.0429 D+C 5$ & $1.4096 \mathrm{D}+02$ & & $2.2879 D-05$ & $1.0035 D+04$ & $5.9511 D-05$ \\
\hline 2530 & $2.05710+05$ & $1.42420+02$ & & $2.5615 \mathrm{D}-05$ & $1.00290+04$ & $5.96940-05$ \\
\hline 2540 & $2.07140+05$ & $1.4392 \mathrm{D}+02$ & & $2.8654 \mathrm{D}-05$ & $1.00230+04$ & $5.9878 \mathrm{D}-05$ \\
\hline 2550 & $2.08590+05$ & $1.4544 \mathrm{D}+02$ & & $3.2024 D-05$ & $1.0017 \mathrm{D}+04$ & $6.00610-05$ \\
\hline 2560 & $2.1005 D+05$ & $1.4700 D+02$ & & $3.57610-05$ & $1.00110+04$ & $6.02450-05$ \\
\hline 2570 & $2.11530+05$ & $1.48590+02$ & & $3.9898 D-0.5$ & $1.00050+04$ & $6.0428 D-35$ \\
\hline 2580 & $2.1302 D+C 5$ & $1.50220+02$ & & $4.4477 D-05$ & $9.999 .3 D+03$ & $6.0612 \mathrm{D}-.05$ \\
\hline 2590 & $2.14530+05$ & $1.5187 D+02$ & & $4.9540 \mathrm{D}-05$ & $9.99320+03$ & $6.0796 \mathrm{D}-05$ \\
\hline $260 \mathrm{C}$ & $2.1606 D+05$ & $1.5357 D+02$ & & $5.51330-05$ & $9.98720+03$ & $6.09 B 0 D-05$ \\
\hline 2610 & $2.1760 D+05$ & $1.5529 D+02$ & & $6.1307 D-05$ & $9.98110+03$ & $6.11640-05$ \\
\hline 2620 & $2.1916 D+05$ & $1.5705 D+02$ & & $6.8117 D-05$ & $9.97490+03$ & $6.1348 D-05$ \\
\hline
\end{tabular}


TREFHODYNAMIC PROPERTIES OF SOLID URANIUM DIOXIDE

\begin{tabular}{|c|c|c|c|c|c|c|}
\hline $\begin{array}{c}T \\
(\mathrm{X})\end{array}$ & $\begin{array}{l}B-H(298) \\
(J / B O L)\end{array}$ & $\begin{array}{c}\text { CP } \\
(J / 4 O L-K)\end{array}$ & $\begin{array}{c}C \nabla \\
(J / B O L-K)\end{array}$ & $\underset{(\Delta P A)}{P}$ & $\begin{array}{c}\mathrm{RHO} \\
(\mathrm{KG} / \mathrm{M} * * 3)\end{array}$ & $\begin{array}{r}\text { AL PHAP } \\
(1 / K)\end{array}$ \\
\hline $263 C$ & $2.20740+05$ & $1.5885 D+02$ & & $7.56240-05$ & $9.9688 D+j 3$ & $6.1532 D-05$ \\
\hline 2640 & $2.22340+05$ & $1.60680+02$ & & $8.38910-05$ & $9.96270+03$ & $6.1717 D-c 5$ \\
\hline 2650 & $2.2396 \mathrm{D}+05$ & $1.62550+02$ & & $9.2989 D-05$ & $9.9565 D+03$ & $6.19010-0.5$ \\
\hline 2660 & $2.25590+05$ & $1.64460+02$ & & $1.0299 \mathrm{D}-04$ & $9.9503 D+03$ & $6.2086 \mathrm{D}-05$ \\
\hline 2670 & $2.2 .7250+05$ & $1.66400+02$ & & $1.1399 \mathrm{D}-04$ & $9.9441 D+03$ & $6.2270 \mathrm{D}-05$ \\
\hline 2680 & $2.29330+05$ & $1.6704 D+02$ & & $1.26060-04$ & $9.93790+03$ & $6.24550-05$ \\
\hline 2690 & $2.3100 D+C 5$ & $1.67 \ni 4 D+02$ & & $1.39310-04$ & $9.9317 D+03$ & $6.2639 D-05$ \\
\hline 2700 & $2.3267 D+05$ & $1.67040+02$ & & $1.53830-C 4$ & $9.9255 \mathrm{D}+03$ & $6.2824 \mathrm{D}-05$ \\
\hline 2710 & $2.34340+05$ & $1.6704 D+02$ & & $1.69750-04$ & $9.9192 D+03$ & $6.3004 D-05$ \\
\hline 2720 & 2. $3601 D+05$ & $1.6704 D+C 2$ & & $1.87170-04$ & $9.91300+03$ & $6.31940-05$ \\
\hline 2730 & $2.37680+05$ & $1.67040+02$ & & $2.06240-04$ & $9.90670+03$ & $6.3379 D-05$ \\
\hline 2740 & $2.3935 D+C 5$ & $1.67 C+D+02$ & & $2.27090-04$ & $9.9004 D+03$ & $6.3564 \mathrm{D}-.25$ \\
\hline 2750 & $2.4102 .0+05$ & $1.67040+02$ & & $2.4987 D-04$ & $9.8941 D+03$ & $6.37490-05$ \\
\hline 2760 & $2.42690+05$ & $1.6704 D+02$ & & $2.74750-04$ & $9.88780+03$ & $6.3935 \mathrm{D}-05$ \\
\hline $277 \mathrm{C}$ & $2.44360+05$ & $1.67040+02$ & & $3.0189 D-04$ & $9.8814 D+03$ & $6.4120 \mathrm{D}-05$ \\
\hline 2780 & $2.4603 D+05$ & $1.6704 D+02$ & & $3.3150 D-04$ & $9.87510+J 3$ & $6.4305 \mathrm{D}-05$ \\
\hline $279 \mathrm{C}$ & $2.47700+05$ & $1.67040+02$ & & $3.637 \in D-04$ & $9.8687 D+03$ & $6.4491 \mathrm{D}-05$ \\
\hline 2820 & $2.4937 D+05$ & $1.6704 D+02$ & & $3.9890 D-04$ & $9.8624 D+03$ & $6.4676 D-05$ \\
\hline $2 \varepsilon 10$ & $2.5104 D+05$ & $1.67040+02$ & & $4.37140-04$ & $9.85600+03$ & $6.4862 \mathrm{D}-05$ \\
\hline 2820 & $2.5271 D+05$ & $1.6704 D+02$ & & $4.7874 \mathrm{D}-04$ & $9.84960+03$ & $6.5048 \mathrm{D}-05$ \\
\hline 2830 & $2.54380+05$ & $1.67040+02$ & & $5.2396 \mathrm{D}-\mathrm{C} 4$ & $9.8431 \mathrm{D}+0.3$ & $6.5233 \mathrm{D}-05$ \\
\hline 2840 & $2.5605 D+05$ & $1.67040+02$ & & $5.73090-04$ & $9.8367 D+03$ & $6.5419 D-05$ \\
\hline 2850 & $2.5772 D+05$ & $1.6704 D+02$ & & $6.2643 \mathrm{D}-04$ & $9.8302 \mathrm{D}+03$ & $5.56050-05$ \\
\hline 2860 & $2.5939 D+C 5$ & $1.67040+02$ & & $6.84310-04$ & $9.8238 D+03$ & $6.57910-05$ \\
\hline 2870 & $2.6106[+05$ & $1.67040+02$ & & $7.4708 D-04$ & $9.8173 D+03$ & $6.5977 D-05$ \\
\hline 2880 & $2.6273 D+05$ & $1.6704 \mathrm{D}+02$ & & $9.1511 \mathrm{D}-04$ & $9.8108 D+33$ & $6.61630-05$ \\
\hline
\end{tabular}


THERMODYNAMIC OROPEKTIES OP SOLID URANIJM DIOXIDE

\begin{tabular}{|c|c|c|c|c|c|c|}
\hline $\begin{array}{l}T \\
(R)\end{array}$ & $\begin{array}{l}H-H(298) \\
(J / H O L)\end{array}$ & $\begin{array}{c}\text { CP } \\
(\mathrm{J} / \mathrm{HOI}-\mathrm{K})\end{array}$ & $\begin{array}{c}\mathrm{CV} \\
(\mathrm{J} / \mathrm{HOL}-\mathrm{K})\end{array}$ & $\underset{(\triangle P A)}{P}$ & $\begin{array}{c}\text { Бно } \\
(\mathrm{KG} / \mathrm{M} * * 3)\end{array}$ & $\begin{array}{c}\text { AL PHAP } \\
(1 / K)\end{array}$ \\
\hline 2890 & $2.6440 D+05$ & $1.6704 \mathrm{D}+02$ & & $8.8880 D-04$ & $9.80430+03$ & $6.6350 D-05$ \\
\hline 2900 & $2.66070+05$ & $1.6704 D+02$ & & $9.68570-n 4$ & $9.7978 D+03$ & $6.6536 \mathrm{D}-05$ \\
\hline 2910 & $2.67740+05$ & $1.67040+02$ & & $1.0549 D-03$ & $9.79120+03$ & $6.6722 D-05$ \\
\hline 2920 & $2.6941 D+05$ & $1.67040+02$ & & $1.1482 D-03$ & $9.7847 D+03$ & $6.6909 D-05$ \\
\hline 2930 & $2.7109 D+05$ & $1.6704 \mathrm{D}+02$ & & $1.2491 \mathrm{D}-03$ & $9.77810+03$ & $6.70950-05$ \\
\hline 2940 & $2.7276 \mathrm{D}+05$ & $1.67040+C 2$ & & $1.3580 D-03$ & $9.77150+C 3$ & $6.7282 D-05$ \\
\hline 2950 & $2.74430+05$ & $1.6764 D+02$ & & $1.4756 \mathrm{D}-03$ & $9.7649 \mathrm{D}+03$ & $6.7468 D-05$ \\
\hline 2560 & $2.76100+05$ & $1.6704 \mathrm{D}+02$ & & $1.6025 D-C .3$ & $9.7583 D+03$ & $6.765 .50-05$ \\
\hline 2970 & $2.7777 D+05$ & $1.6704 D+02$ & & $1.7393 D-03$ & $9.7517 D+03$ & $6.7842 \mathrm{D}-05$ \\
\hline 2980 & $2.7 \subsetneq 44 D+05$ & $1.6704 D+02$ & & $1.8868 D-03$ & $9.74510+03$ & $6.8029 D-05$ \\
\hline 2990 & $2.81110+05$ & $1.6704 \mathrm{D}+02$ & & $2.0457 \mathrm{D}-03$ & $9.7384 D+03$ & $6.8215 D-05$ \\
\hline $300 \mathrm{C}$ & $2.8278 D+05$ & $1.67040+02$ & & $2.2167 D-03$ & $9.7317 D+03$ & $6.8402 \mathrm{D}-05$ \\
\hline 3010 & $2.8445 D+05$ & $1.6704 D+02$ & & $2.4008 \mathrm{D}-03$ & $9.7251 D+03$ & $6.8589 D-05$ \\
\hline 3020 & $2.8612 D+05$ & $1.6704 \mathrm{D}+02$ & & $2.5988 D-03$ & $9.7184 D+03$ & $6.87770-05$ \\
\hline 3030 & $2.8779 D+05$ & $1.6704 D+02$ & & $2.8117 \mathrm{D}-03$ & $9.7116 D+\cup 3$ & $6.8964 D-05$ \\
\hline 3040 & $2.8946 \mathrm{D}+05$ & $1.6704 D+02$ & & $3.0404 \mathrm{D}-03$ & $9.70490+03$ & $6.9151 \mathrm{D}-05$ \\
\hline 3050 & $2.91130+05$ & $1.67040+02$ & & $3.2860 \mathrm{D}-03$ & $9.6982 \mathrm{D}+03$ & $6.9338 D-05$ \\
\hline 3060 & $2.9280 D+C 5$ & $1.6704 \mathrm{D}+02$ & & $3.5497 D-03$ & $9.6914 D+33$ & $6.95260-05$ \\
\hline 3070 & $2.94470+05$ & $1.6704 D+92$ & & $3.8326 \mathrm{D}-03$ & $9.6847 D+03$ & $6.9713 \mathrm{D}-05$ \\
\hline 3080 & $2.96140+05$ & $1.67 C 4 D+02$ & & $4.1359 D-03$ & $9.6779 D+03$ & $6.99000-05$ \\
\hline 3090 & $2.9781 D+C 5$ & $1.6704 D+02$ & & $4.4611 D-03$ & $9.67110+03$ & $7.00880-05$ \\
\hline 3100 & $2.9948 D+05$ & $1.67040+02$ & & $4.8095 D-03$ & $9.66+3 \mathrm{D}+03$ & $7.0276 \mathrm{D}-05$ \\
\hline 3110 & $3.0115 \mathrm{D}+05$ & $1.67 C 4 D+02$ & & $5.18270-03$ & $9.6575 D+03$ & $7.0463 \mathrm{D}-05$ \\
\hline 3120 & $3.0282 \mathrm{D}+0.5$ & $1.67040+02$ & & $5.5820 \mathrm{D}-03$ & $9.6506 \mathrm{D}+03$ & $7.0651 D-05$ \\
\hline
\end{tabular}


THERMODYNAMIC PROPEHTIES OF LIQUIO ORANIUH DIOXIDE

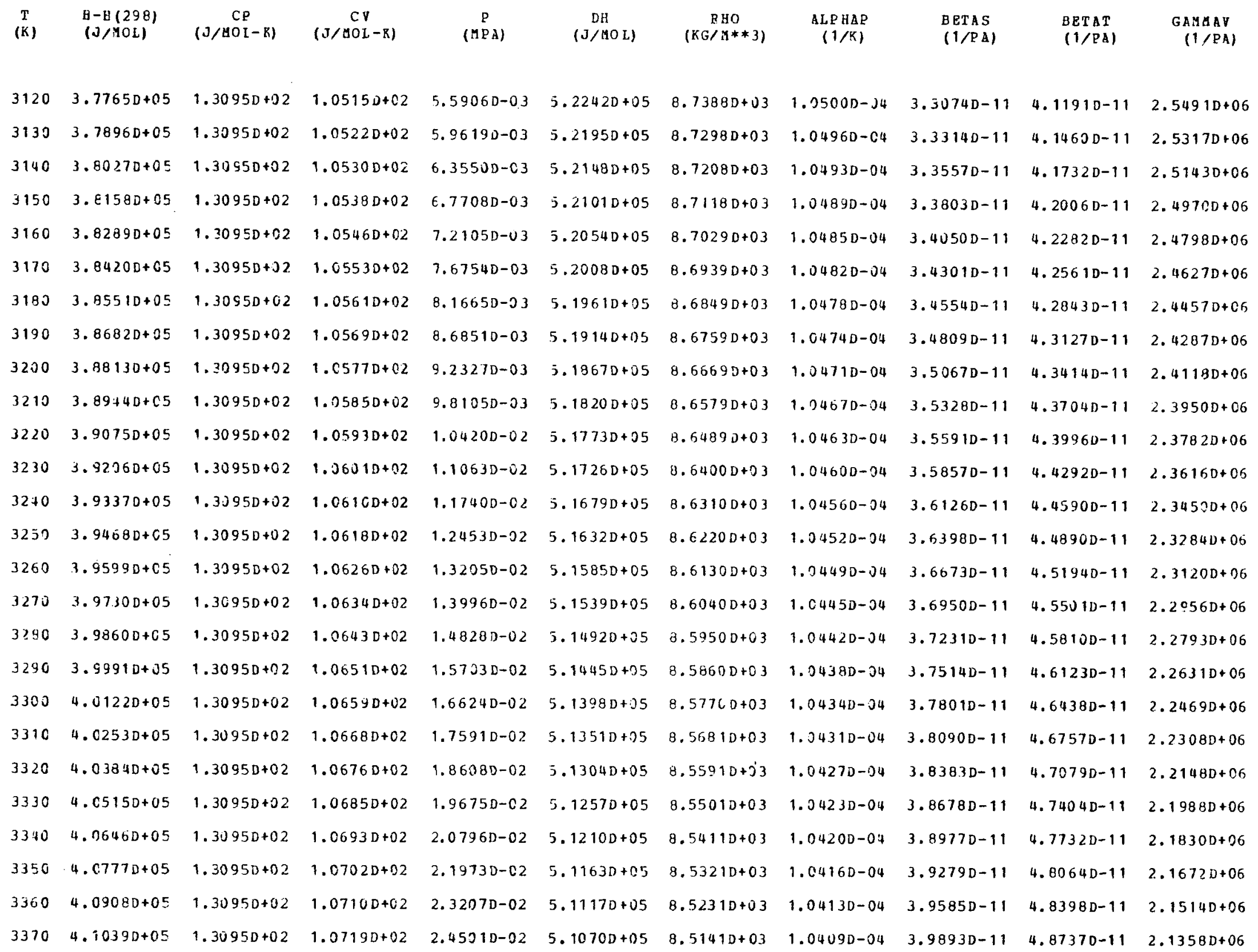


THEEMODYNAMIC PROPERTIES OP LIQUID URANIUE DIOXIDE

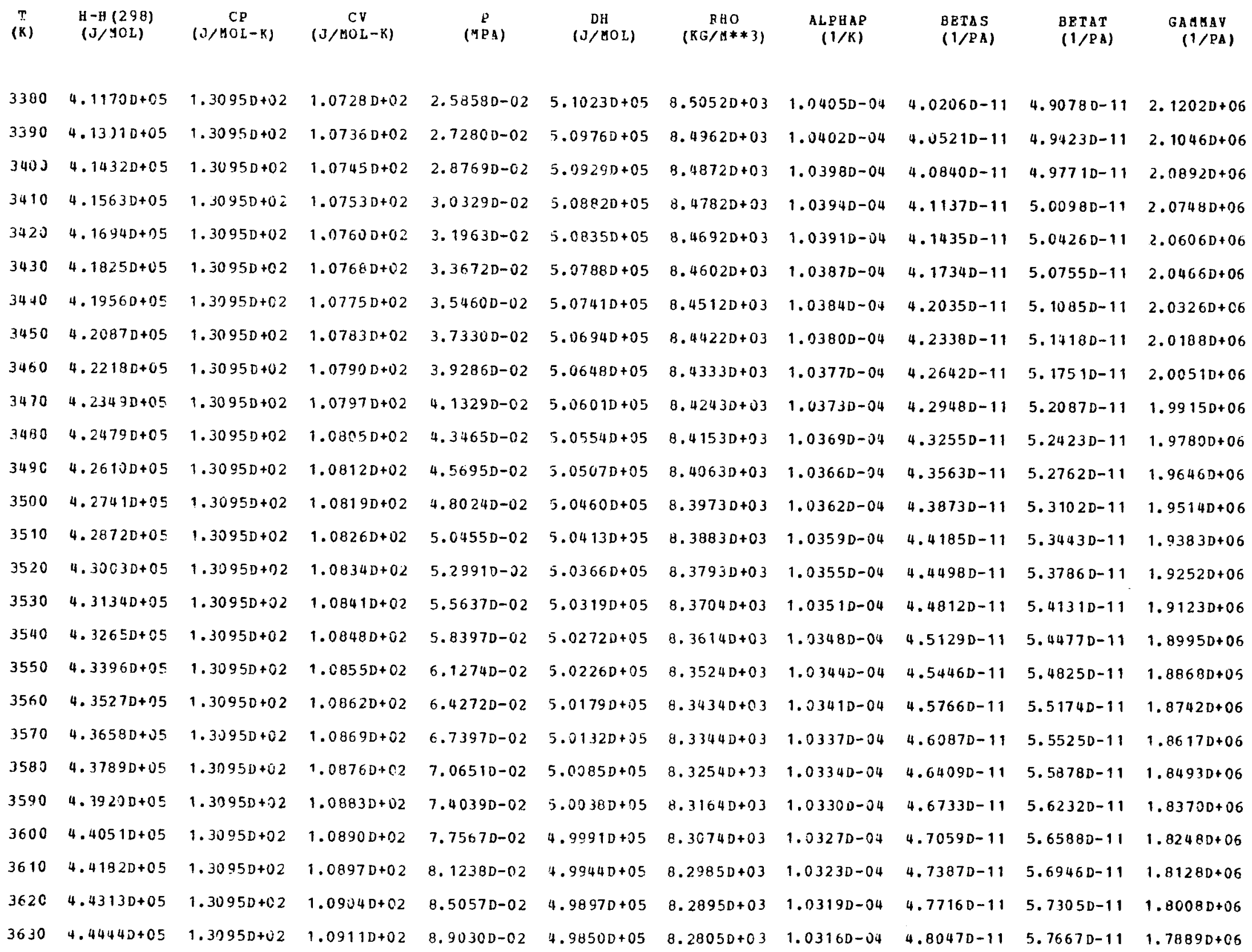


THEBMODYMAUIC PBOPERTIES OF LIQUID URANIUM DIOXIDE

\begin{tabular}{|c|c|c|c|c|c|c|c|c|c|c|}
\hline $\begin{array}{l}T \\
(K)\end{array}$ & $\begin{array}{l}-H(298) \\
J / H O L)\end{array}$ & $\begin{array}{c}\text { CE } \\
(J / 4 O I-K)\end{array}$ & $\begin{array}{c}C V \\
J / M O L-K)\end{array}$ & $\underset{(M P A)}{P}$ & $\begin{array}{c}\text { DH } \\
(\mathrm{J} / \mathrm{HOL})\end{array}$ & $\begin{array}{c}R \cup 0 \\
(K G / M * * 3)\end{array}$ & & & & $\begin{array}{l}\text { GAMGAV } \\
(1 / P A)\end{array}$ \\
\hline 3640 & $.4575 D+05$ & $.3095 D+02$ & $.0917 D+02$ & $.31610-02$ & $.9804 \mathrm{D}+05$ & $8.2715 D+C 3$ & $1.0312 \mathrm{D}-04$ & $4.8379 D-11$ & $5.80290-11$ & $1.77710+06$ \\
\hline 3650 & $4.47060+05$ & $.3095 E+02$ & $.0924 \mathrm{D}+02$ & $9.74550-02$ & $4.97570+05$ & $8.26250+03$ & $1.03090-04$ & $4.8714 \mathrm{D}-11$ & $5.8394 \mathrm{D}-11$ & $1.7654 D+06$ \\
\hline 3660 & $.4837 D+05$ & $.3995 D+02$ & $.0931 D+02$ & $.01920-01$ & $.9710 D+05$ & $8.2535 D+03$ & $1.03050-04$ & $4.9050 \mathrm{D}-11$ & $5.87600-11$ & $1.75380+06$ \\
\hline 3670 & $4968 D+05$ & $.3095 D+C 2$ & $.0938 \mathrm{D}+02$ & $.06550-01$ & $.9663 D+05$ & $8.2445 \mathrm{D}+03$ & $1.0302 D-04$ & $4.9387 \mathrm{D}-11$ & $5.91290-11$ & $1.74230+06$ \\
\hline 3680 & $5098 D+05$ & $.3095 \mathrm{D}+02$ & $.09440+02$ & $.11370-01$ & $4.9616 D+05$ & 8. $2356 \mathrm{D}+03$ & $1.0298 D-04$ & $4.9727 D-11$ & $5.9498 \mathrm{D}-11$ & $1.7308 D+06$ \\
\hline 690 & $.52290+05$ & $.3095 D+02$ & $.0951 \mathrm{D}+02$ & $.1637 D-01$ & $4.95690+05$ & B. $2266 \mathrm{D}+03$ & $1.0295 \mathrm{D}-04$ & $5.0068 \mathrm{D}-11$ & $5.9870 \mathrm{D}-11$ & $1.7195 \mathrm{D}+06$ \\
\hline 3720 & $53600+05$ & $.30950+02$ & $.0958 D+02$ & $.2156 \mathrm{D}-01$ & $4.9522 D+05$ & $8.2176 \mathrm{D}+03$ & $1.0291 \mathrm{D}-04$ & $5.0411 \mathrm{D}-11$ & $6.0244 \mathrm{D}-11$ & $1.7082 D+06$ \\
\hline 710 & $5491 D+C 5$ & $.30950+92$ & $.09640+02$ & $26950-01$ & $4.94750+05$ & $8.2086 D+C 3$ & $1.0288 \mathrm{D}-04$ & $5.0755 \mathrm{D}-11$ & $6.0619 \mathrm{D}-11$ & $1.69710+06$ \\
\hline 3720 & $56220+05$ & $.30950+02$ & $.0971 D+C 2$ & $3254 D-01$ & $1.9428 D+05$ & 8. $1996 D+03$ & $1.02840-04$ & $5.1102 \mathrm{D}-11$ & $6.0996 \mathrm{D}-11$ & $1.6860 D+06$ \\
\hline 3730 & $5753 D+05$ & 1.3095D+02 & $.0977 D+02$ & $38340-01$ & $4.93810+0.5$ & $8.1906 \mathrm{D}+03$ & $1.0281 D-04$ & $5.14500-11$ & $6.1375 D-11$ & $1.6750 D+06$ \\
\hline 3750 & $60150+05$ & $1.30950+02$ & $1.09900+02$ & $50590-01$ & $4.92880+05$ & $8.1726 D+03$ & $1.02730-04$ & $2152 D-11$ & $6.21390-11$ & $1.65330+06$ \\
\hline 3760 & $6146 \mathrm{D}+05$ & & & $D-01$ & $1.92410+05$ & $8.16370+03$ & $1.0270 \mathrm{D}-04$ & $5060-11$ & $25230-11$ & $.6426 \mathrm{D}+06$ \\
\hline 3770 & & & $1003 D+C 2$ & $6375 \mathrm{D}-01$ & $4.91940+05$ & & $1.0266 \mathrm{D}-04$ & $862 D-11$ & $9100-11$ & $1.63190+06$ \\
\hline 780 & & & & $10690-01$ & & $3.1457 D+03$ & $630-04$ & $9 D-11$ & $3298 D-11$ & \\
\hline 790 & & & & 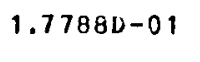 & 05 & & 4 & & $16890-11$ & 6 \\
\hline 800 & 年 & & & $8532 D-01$ & $4.90530+05$ & $8.1277 D+03$ & $560-04$ & $5.3940 \mathrm{D}-11$ & $6.4081 \mathrm{D}-11$ & $1.60050+06$ \\
\hline $81 \mathrm{C}$ & & & & $302 D-01$ & $9006 \mathrm{D}+05$ & $8.1187 D+03$ & $1.02520-04$ & $5.4304 \mathrm{D}-11$ & $6.4475 D-11$ & $1.59010+06$ \\
\hline 820 & & . & & $00990-01$ & $4.89590+25$ & $8.10970+03$ & $1.02490-04$ & $5.4669 \mathrm{D}-11$ & $6.4872 D-11$ & $1.5799 D+06$ \\
\hline 830 & 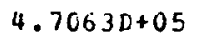 & & $D+02$ & $0924 \mathrm{D}-01$ & $4.89130+05$ & $8.1008 D+03$ & $1.0245 D-04$ & & $6.5270 \mathrm{D}-11$ & $1.5697 \mathrm{D}+06$ \\
\hline 3840 & 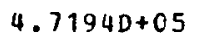 & DTUE & $1.1048 \mathrm{D}+02$ & $.1778 \mathrm{D}-01$ & $4.8866 D+05$ & $8.09180+03$ & $1.02420-04$ & $5.54050-11$ & $6.5670 \mathrm{D}-11$ & $1.5596 \mathrm{D}+06$ \\
\hline 3850 & - & - & $1.1054 D+02$ & $2.26610-01$ & $4.8819 D+05$ & & $1.0238 D-04$ & & $6.60730-11$ & $1.5496 D+06$ \\
\hline 3870 & (2) & 1.3095 & $1.1067 D+02$ & $2.4517 \mathrm{D}-01$ & $4.8725 D+05$ & $8.0648 \mathrm{D}+03$ & $1.0231 \mathrm{D}-04$ & & $6.6883 \mathrm{D}-11$ & $1.5297 \mathrm{D}+06$ \\
\hline 3880 & - Mrdoraz & $1.30950+02$ & $1.1073 D+02$ & $2.5492 \mathrm{D}-01$ & $4.8678 D+05$ & $8.05580+03$ & $1.02280-04$ & $5.6902 \mathrm{D}-11$ & $6.7292 \mathrm{D}-11$ & $1.51990+06$ \\
\hline (2) & $.7848 D+C 5$ & $1.3095 D+32$ & $1.10790+02$ & 6500D-01 & $4.86310+05$ & $8.0468 D+03$ & $1.0224 D-04$ & & 6.77 & $1.51020+05$ \\
\hline
\end{tabular}


THERUODYNALIC FQOPERTIES OF LIQUID URANIUH DIOXIDE

\begin{tabular}{|c|c|c|c|c|c|c|c|c|c|c|}
\hline $\begin{array}{c}T \\
(K)\end{array}$ & $\begin{array}{l}\mathrm{H}-\mathrm{H}(298) \\
(\mathrm{J} / \mathrm{BCL})\end{array}$ & $\begin{array}{c}C P \\
(J / M O I-K)\end{array}$ & $\begin{array}{c}C V \\
(J / M O L-K)\end{array}$ & $\underset{(M P A)}{P}$ & $\begin{array}{c}\text { DH } \\
(\mathrm{J} / \mathrm{MOL})\end{array}$ & $\begin{array}{c}R H O \\
(K G / M * * 3)\end{array}$ & $\begin{array}{c}\text { ALPHAP } \\
(1 / K)\end{array}$ & $\begin{array}{l}\text { BETAS } \\
\text { (1/PA) }\end{array}$ & $\begin{array}{l}\text { BETAT } \\
(1 / \text { PA })\end{array}$ & $\begin{array}{l}\text { GAEUAV } \\
(1 / P A)\end{array}$ \\
\hline 3900 & $4.7979 D+05$ & $1.3095 D+02$ & $1.10860+02$ & $2.75410-01$ & $4.8584 D+05$ & $9.03790+03$ & $1.02210-04$ & $5.7663 D-11$ & $6.8115 \mathrm{D}-11$ & $1.5005 D+06$ \\
\hline 3910 & 4. $81100+05$ & $1.3095 D+02$ & $1.1092 D+02$ & $2.8617 \mathrm{D}-01$ & $4.85370+05$ & $8.0289 D+03$ & $1.0217 D-04$ & $5.8046 \mathrm{D}-11$ & $6.85300-11$ & $1.4910 \mathrm{D}+\mathrm{J6}$ \\
\hline 3920 & 4. $\varepsilon 2410+05$ & $1.30950+02$ & $1.10980+02$ & $2.97270-01$ & $4.84910+05$ & $8.0199 \mathrm{D}+03$ & $1.02140-04$ & $5.84320-11$ & $6.89470-11$ & 1. $4814 \mathrm{D}+06$ \\
\hline 3930 & $4.83720+05$ & $1.3095 D+02$ & $1.11040+02$ & $3.0873 \mathrm{D}-\mathrm{C1}$ & $4.8444 D+05$ & $8.01090+03$ & $1.02110-04$ & $5.88200-11$ & $6.9366 \mathrm{D}-11$ & $1.4720 D+06$ \\
\hline 3940 & $4.85030+05$ & $1.3095 D+02$ & $1.1110 D+C 2$ & $3.2057 \mathrm{D}-01$ & $+.8397 D+05$ & $8.0019 D+03$ & $1.0207 D-04$ & $5.9209 D-11$ & $6.9788 \mathrm{D}-11$ & $1.4626 D+06$ \\
\hline 3950 & $4.86340+05$ & $1.3095 D+02$ & $1.11160+02$ & $3.3278 D-01$ & $4.83500+05$ & $7.9929 \mathrm{D}+03$ & $1.02040-04$ & $5.96010-11$ & $7.02110-11$ & $1.4533 \mathrm{D}+06$ \\
\hline 3960 & $4.8765 D+05$ & $1.3095 D+02$ & $1,1122 D+02$ & $3.45380-01$ & $4.83030+05$ & $7.98390+03$ & $1.0200 \mathrm{D}-04$ & $5.9996 \mathrm{D}-11$ & $7.0637 \mathrm{D}-11$ & $1.44400+06$ \\
\hline 3970 & $4.8896 D+05$ & $1.3095 D+02$ & $1.1128 D+02$ & $3.5837 \mathrm{D}-01$ & $4.825 \in D+05$ & $7.9749 \mathrm{D}+03$ & $1.0197 D-04$ & $6.0392 \mathrm{D}-11$ & 7. $1065 \mathrm{D}-11$ & $1.4348 D+06$ \\
\hline 3980 & $4.9027 D+C 5$ & $1.3095 D+C 2$ & $1.11340+02$ & $3.7177 \mathrm{D}-01$ & $4.82090+05$ & $7.9660 \mathrm{D}+03$ & $1.0193 \mathrm{D}-04$ & $6.0791 D-11$ & $7.14950-11$ & 1. $42570+06$ \\
\hline 3990 & $4.9158 D+C 5$ & $1.30950+02$ & $1.11400+02$ & $3.8559 D-01$ & $4.81620+05$ & $7.9570 \mathrm{D}+03$ & $1.01900-04$ & $6.1191 D-11$ & $7.1928 \mathrm{D}-11$ & $1.4167 D+06$ \\
\hline 4000 & $4.92890+05$ & $1.30950+02$ & $1.1146 D+02$ & $3.9984 \mathrm{D}-01$ & $4.8115 D+05$ & $7.9480 \mathrm{D}+03$ & $1.01860-04$ & $6.15940-11$ & $7.2363 \mathrm{D}-11$ & $1.4077 D+06$ \\
\hline 4010 & $4.94200+05$ & $1.30950+02$ & $1.1152 D+02$ & $4.1452 \mathrm{D}-01$ & $4.8068 D+05$ & $7.9390 D+03$ & $1.0183 D-04$ & $6.20000-11$ & $7.28000-11$ & $1.3987 D+06$ \\
\hline 4020 & 4. $\$ 5510+C 5$ & $1.30950+02$ & $1.1158 D+C 2$ & $4.2965 \mathrm{D}-01$ & $4.8022 \mathrm{D}+05$ & $7.9300 D+03$ & $1.01790-04$ & $6.2407 D-11$ & $7.3239 \mathrm{D}-11$ & 1. $3899 D+06$ \\
\hline 4030 & $4.9682 D+05$ & $1.3095 D+C 2$ & $1.1164 D+02$ & $4.4523 \mathrm{D}-01$ & $4.79750+05$ & $7.9210 \mathrm{D}+03$ & $1.0176 \mathrm{D}-04$ & $6.2817 D-11$ & $7.36810-11$ & $1.38110+06$ \\
\hline 4040 & $4.9813 D+05$ & $1.3095 D+02$ & $1.11700+02$ & $4.6129 \mathrm{D}-01$ & $4.7928 D+05$ & $7.9120 \mathrm{D}+03$ & $1.0172 \mathrm{D}-04$ & $6.3230 D-11$ & $7.4125 \mathrm{D}-11$ & $1.37230+06$ \\
\hline 4050 & $4.99440+05$ & $1.3095 D+\cup 2$ & $1.11760+02$ & $4.7782 \mathrm{D}-01$ & $4.78810+05$ & $7.9031 \mathrm{D}+03$ & $1.0169 D-04$ & $6.3644 \mathrm{D}-11$ & $7.4572 \mathrm{D}-11$ & $1.3637 D+06$ \\
\hline 4060 & $5.00750+05$ & $1.30950+02$ & $1.1182 \mathrm{D}+02$ & $4.94840-01$ & $4.78340+05$ & $7.8941 \mathrm{D}+03$ & $1.01660-04$ & $0.4061 \mathrm{D}-11$ & $7.50210-11$ & $1.3550 D+06$ \\
\hline 4070 & $5.02060+05$ & $1.3095 D+02$ & $1.1188 D+C 2$ & $5.1236 D-01$ & $4.7787 D+05$ & $7.8851 D+03$ & $1.0162 D-04$ & $6.4481 D-11$ & $7.5472 \mathrm{D}-11$ & $1.3465 D+06$ \\
\hline 4080 & $5.0336 D+05$ & $1.30950+02$ & $1.1194 \mathrm{D}+02$ & $5.3040 D-01$ & $4.77400+05$ & $7.8761 \mathrm{D}+03$ & $1.0159 \mathrm{D}-04$ & $6.4902 \mathrm{D}-11$ & $7.5926 \mathrm{D}-11$ & $1.33800+06$ \\
\hline 4090 & $5.0467 D+05$ & 1. $3055 D+02$ & $1.1200 \mathrm{D}+02$ & $5.48960-01$ & $4.7693 D+05$ & $7.8671 \mathrm{D}+03$ & $1.01550-04$ & $6.5327 \mathrm{D}-11$ & $7.6383 \mathrm{D}-11$ & $1.32 \% 5 \mathrm{D}+06$ \\
\hline 4100 & $5 . C 598 D+05$ & $1.3095 \mathrm{D}+02$ & $1.1205 D+02$ & $5.6805 \mathrm{D}-01$ & $4.7646 \mathrm{D}+05$ & $7.85810+03$ & $1.0152 \mathrm{D}-04$ & $6.5753 D-11$ & $7.68410-11$ & $1.32110+06$ \\
\hline 4110 & $5.0729 D+05$ & $1.3095 D+02$ & 1. $1211 \mathrm{D}+02$ & $5.87690-01$ & $4.7600 D+05$ & $7.8491 \mathrm{D}+03$ & $1.0148 \mathrm{D}-04$ & $6.6183 \mathrm{D}-11$ & $7.73030-11$ & 1. $3128 D+06$ \\
\hline 4120 & $5.0860 D+05$ & $1.3095 \mathrm{D}+02$ & 1. $1217 D+02$ & $6.07890-01$ & $4.7553 D+05$ & $7.84010+03$ & $1.0145 \mathrm{D}-04$ & $6.6614 \mathrm{D}-11$ & $7.7767 D-11$ & $1.30450+06$ \\
\hline 4130 & $5.09910+05$ & $1.3095 D+C 2$ & $1.12 \angle 3 D+02$ & $6.2866 \mathrm{D}-01$ & $4.7506 D+05$ & $7.8312 \mathrm{D}+03$ & $1.01410-04$ & $6.7048 \mathrm{D}-11$ & $7.8233 \mathrm{D}-11$ & $1.2963 \mathrm{D}+06$ \\
\hline 4140 & $5.1122 \mathrm{D}+\mathrm{CS}$ & $1.3095 v+c_{2}$ & $1.1229 D+02$ & $6.50010-01$ & $4.74590+05$ & $7.8222 \mathrm{D}+03$ & $1.0138 D-04$ & $6.74850-11$ & $7.8702 \mathrm{D}-11$ & $1.2802 D+06$ \\
\hline 4150 & $5.1253 \mathrm{D}+05$ & $1.3095 D+02$ & $1.1234 D+02$ & $6.7196 \mathrm{D}-01$ & $4.7412 \mathrm{D}+05$ & $7.8132 \mathrm{D}+\mathrm{C} 3$ & $1.01350-04$ & $6.7924 \mathrm{D}-11$ & $7.91740-11$ & 1. $2800 D+06$ \\
\hline
\end{tabular}


THERMODYNAMIC PROPEBTIES OF LIQUID URANIOH DIOXIDE

\begin{tabular}{|c|c|c|c|c|c|c|c|c|c|c|}
\hline$\stackrel{T}{(K)}$ & $\begin{array}{l}H-H(298) \\
(J / \triangle O L)\end{array}$ & $\begin{array}{c}C P \\
(J / M C L-R)\end{array}$ & $\begin{array}{c}C V \\
(J / \text { MOL-X) }\end{array}$ & $\begin{array}{c}P \\
\left(Y_{A}\right)\end{array}$ & $\begin{array}{c}\text { DH } \\
(\mathrm{J} / \mathrm{MOL})\end{array}$ & $\begin{array}{c}E H O \\
(K G / \Delta * * 3)\end{array}$ & $\begin{array}{c}\text { ALPHAP } \\
(1 / K)\end{array}$ & $\begin{array}{l}\text { BETAS } \\
(1 / \mathrm{PA})\end{array}$ & $\begin{array}{l}\text { BETAT } \\
(1 / P A)\end{array}$ & $\begin{array}{l}\text { GAMUAV } \\
(1 / P A)\end{array}$ \\
\hline 4160 & $5.1394 D+05$ & $1.3095 D+02$ & $1.12400+02$ & $6.94510-01$ & $7.73650+05$ & $7.80420+03$ & $1.01310-04$ & $6.8366 D-11$ & 7. $9648 \mathrm{D}-11$ & $1.2720 \mathrm{D}+06$ \\
\hline 4170 & $5.1515 D+05$ & $1.3095 \mathrm{D}+02$ & $1.1246 \mathrm{D}+02$ & 7. $1768 \mathrm{D}-01$ & $4.73180+05$ & $7.7952 D+03$ & $1.0128 D-04$ & $6.8811 \mathrm{D}-11$ & $8.0125 \mathrm{D}-11$ & $1.26400+06$ \\
\hline 4180 & $5.1646 D+0 S$ & $1.3095 D+02$ & $1.1252 \mathrm{D}+02$ & $7.41490-01$ & $4.7271 D+05$ & $7.78620+03$ & $1.01240-04$ & $6.9258 \mathrm{D}-11$ & $8.0605 D-11$ & 1. $25600+06$ \\
\hline 4190 & $5.17770+05$ & $1.3095 D+02$ & $1.1 \angle 57 D+C 2$ & $7.65940-01$ & $+.7224 D+05$ & $7.7772 D+03$ & $1.01210-04$ & $6.9707 D-11$ & $8.1087 D-11$ & 1. $2482 D+06$ \\
\hline 4200 & $5.190 B D+05$ & 1. $3095 D+C 2$ & $1.1263 D+02$ & $7.9106 \mathrm{D}-01$ & $4.7178 D+05$ & $7.76830+03$ & $1.0118 \mathrm{D}-04$ & $7.0160 D-11$ & $8.1572 \mathrm{D}-11$ & $1.24030+06$ \\
\hline 4210 & $5.20390+05$ & $1.30950+02$ & 1. $1269 D+C 2$ & $8.16840-01$ & $4.7131 D+05$ & $7.75930+03$ & $1.0114 \mathrm{D}-04$ & $7.0615 \mathrm{D}-11$ & $8.20600-11$ & $1.23250+06$ \\
\hline 4220 & $5.2170 D+05$ & $1.3095 D+92$ & $1.1274 D+02$ & $8.4331 \mathrm{D}-01$ & $4.7 C 84 D+05$ & $7.7503 D+03$ & $1.01110-04$ & $7.1073 D-11$ & $3.2551 \mathrm{n}-11$ & 1. $2248 D+06$ \\
\hline 4230 & $5.23010+05$ & $1.3095 D+02$ & 1. $12800+02$ & $8.70480-01$ & $4.70370+05$ & $7.74130+03$ & $1.0107 \mathrm{D}-04$ & 7. $1533 \mathrm{D}-11$ & $8.30440-11$ & $1.2171 \mathrm{D}+05$ \\
\hline 4240 & $5.2432 D+05$ & $1.3095 D+02$ & 1. $1286 \mathrm{D}+02$ & $8.9836 D-C 1$ & $4.6990 D+05$ & $7.73230+03$ & $1 . n 1040-04$ & $7.1997 \mathrm{D}-11$ & $8.3540 D-11$ & $1.20950+06$ \\
\hline 4250 & $5.256 .3 D+05$ & $1.3095 D+C 2$ & 1. $12910+C 2$ & $9.2696 \mathrm{D}-01$ & $4.6943 \mathrm{D}+05$ & $7.7233 \mathrm{D}+03$ & $1.01010-04$ & $7.24630-11$ & $0.4039 \mathrm{D}-11$ & $1.2019 D+06$ \\
\hline 4260 & $5.26940+05$ & $1.30950+02$ & $1.1297 D+02$ & $9.56310-01$ & $4.6896 \mathrm{D}+25$ & $7.71430+03$ & $1.0097 \mathrm{D}-04$ & $7.29320-11$ & $8.45410-11$ & $1.1943 D+06$ \\
\hline 4270 & $5.28250+05$ & $1.30950+02$ & 1. $1302 D+02$ & $9.86410-01$ & $4.68490+05$ & $7.70530+03$ & $1.0094 \mathrm{D}-94$ & $7.3404 \mathrm{D}-11$ & $8.50460-11$ & $1.1869 D+06$ \\
\hline 4280 & $5.2955 D+05$ & $1.30950+02$ & $1.1308 D+02$ & $1.01730+00$ & $4.6802 D+95$ & $7.69640+03$ & $1.0090 \mathrm{D}-04$ & $7.3878 \mathrm{D}-11$ & $8.55540-11$ & $1.1794 D+06$ \\
\hline 4290 & $5.3086 D+05$ & $1.30950+02$ & $1.1314 D+02$ & $1.04830+00$ & $4.6755 D+05$ & $7.68740+03$ & $1.00870-04$ & $7.43560-11$ & $8.60650-11$ & $1.1720 \mathrm{D}+06$ \\
\hline 4300 & $\cdot 3217 D+05$ & 1. $3095 D+02$ & $1.1 .319 D+02$ & $1.0814 \mathrm{D}+00$ & $4.67090+05$ & $7.6784 D+03$ & $1.00840-04$ & $7.48370-11$ & $8.6578 \mathrm{D}-11$ & $1.1647 \mathrm{D}+06$ \\
\hline 4310 & $.3348 D+05$ & $1.3095 D+02$ & $1.1325 \mathrm{D}+02$ & $1.1147 D+00$ & $4.66620+05$ & $7.66940+03$ & $1.00800-04$ & $7.5320 D-11$ & $8.70950-11$ & $1.1574 \mathrm{D}+06$ \\
\hline 4320 & $.34790+05$ & $1.3095 D+\hat{U} 2$ & $1.13300+02$ & $1.1487 D+00$ & $4.6615 D+35$ & $7.66040+03$ & $1.00770-04$ & $7.5807 D-11$ & $8.76150-11$ & $1.15010+06$ \\
\hline $433 \mathrm{C}$ & $\cdot 36100+05$ & $1.3095 \mathrm{D}+02$ & $1.1336 \mathrm{D}+02$ & $1.18370+00$ & $4.6568 \mathrm{D}+0.5$ & $7.65140+03$ & $1.0073 \mathrm{D}-04$ & $7.6296 \mathrm{D}-11$ & $8.8138 D-11$ & $1.1429 D+06$ \\
\hline 4340 & $5.37+10+05$ & $1.3095 D+92$ & $1.1341 D+02$ & $1.21950+00$ & $4.6521 D+05$ & $7.6424 \mathrm{D}+03$ & $1.00700-04$ & $7.67890-11$ & $8.8663 \mathrm{D}-11$ & $1.1358 D+06$ \\
\hline 4350 & $5.38720+05$ & $1.3095 D+02$ & $1.1347 D+02$ & $1.2561 \mathrm{D}+00$ & $4.6474 \mathrm{D}+05$ & $7.6335 \mathrm{D}+03$ & $1.0067 D-04$ & $7.7284 \mathrm{D}-11$ & $8.9192 D-11$ & $1.12860+06$ \\
\hline 4360 & $5.40030+05$ & $1.30950+02$ & $1.1352 D+02$ & $1.2937 D+00$ & $4.6427 D+05$ & $7.6245 \mathrm{D}+03$ & $1.00630-04$ & $7.77830-11$ & $8.9725 D-11$ & $1.1216 D+06$ \\
\hline 4370 & $5.41340+05$ & $1.3095 D+02$ & 1. $1358 \mathrm{D}+02$ & $1.3321 \mathrm{D}+00$ & $4.6380 D+05$ & $7.6155 D+03$ & $1.00600-04$ & $7.8285 D-11$ & $9.0260 D-11$ & $1.1145 \mathrm{D}+06$ \\
\hline 4380 & $5.4265 \mathrm{D}+05$ & $1.3095 D+02$ & $1.1363 \mathrm{D}+02$ & $1.37150+00$ & $4.63330+05$ & $7.60650+03$ & $1.00570-04$ & $7.87900-11$ & $9.0798 \mathrm{D}-11$ & $1.10760+06$ \\
\hline 4390 & $5.4396 \mathrm{D}+05$ & $1.3095 D+02$ & $1.1369 D+02$ & $1.4118 D+00$ & $4.6287 D+05$ & $7.5975 \mathrm{D}+03$ & & $7.9298 \mathrm{D}-11$ & $9.1342 \mathrm{D}-11$ & $1.10 .06 D+06$ \\
\hline 440 & $5.4527 D+05$ & $1.3095 D+02$ & $1.1374 D+02$ & $1.4531 \mathrm{D}+00$ & $4.624 C D+05$ & $7.5885 \mathrm{D}+03$ & $1.00500-04$ & $7.98090-11$ & $9.1885 \mathrm{D}-11$ & $1.0937 \mathrm{D}+06$ \\
\hline $447 \mathrm{C}$ & $5.4658 D+05$ & $1.3095 D+02$ & $1.13790+02$ & $1.4953 \mathrm{D}+00$ & $4.6193 D+05$ & $7.5795 D+03$ & $1.00460-04$ & $8.03240-11$ & $9.24330-11$ & $1.0860 D+C 5$ \\
\hline
\end{tabular}


THERMODINAGIC PBOPERTIES OF LIQUID URABIUL DIOXIDE

\begin{tabular}{|c|c|c|c|c|c|c|c|c|c|c|}
\hline $\begin{array}{l}T \\
\text { (K) }\end{array}$ & $\begin{array}{l}\mathrm{H}-\mathrm{H}(298) \\
(\mathrm{J} / \mathrm{MOL})\end{array}$ & $\begin{array}{c}C P \\
(J / H O L-K)\end{array}$ & $\begin{array}{c}C V \\
(J / M O L-X)\end{array}$ & $\underset{(\mathrm{MFA})}{\mathrm{P}}$ & $\begin{array}{c}\text { DH } \\
(J / \mathrm{MOL})\end{array}$ & $\begin{array}{c}B H O \\
(K G / 4 * * 3)\end{array}$ & $\begin{array}{r}\text { ALPHAP } \\
(1 / K)\end{array}$ & $\begin{array}{l}\text { BETAS } \\
(1 / \mathrm{PA})\end{array}$ & $\begin{array}{l}\text { BETAT } \\
(1 / \mathrm{PA})\end{array}$ & $\begin{array}{l}\text { GAYYAV } \\
\text { (1/PA) }\end{array}$ \\
\hline 4420 & $5.47890+05$ & $1.3095 D+02$ & $1.1385 D+02$ & $1.5385 D+00$ & $4.6146 \mathrm{D}+05$ & $7.5705 D+03$ & $1.00430-04$ & $8.0842 D-11$ & $9.29850-11$ & $1.08010+06$ \\
\hline 4430 & $5.49200+05$ & 1. $3095 D+02$ & 1. $1390 D+02$ & $1.5827 D+00$ & $4.60990+05$ & $7.5616 \mathrm{D}+03$ & $1.00400-04$ & $8.1363 D-11$ & $9.35400-11$ & $1.0733 \mathrm{D}+06$ \\
\hline 4440 & $5.5 C 51 D+C 5$ & $1.3095 D+02$ & $1.13960+02$ & $1.6280 \mathrm{D}+00$ & $4.6052 D+05$ & $7.55260+03$ & $1.0036 \mathrm{D}-04$ & $8.18980-11$ & $9.4099 \mathrm{D}-11$ & $1.0 \in 66 \mathrm{D}+06$ \\
\hline 4450 & $5.51820+C E$ & $1.3095 D+02$ & $1.14010+02$ & $1.6742 \mathrm{D}+\mathrm{CO}$ & $4.6005 D+05$ & $7.5436 \mathrm{D}+03$ & $1.0033 D-04$ & $8.2416 D-11$ & $9.46600-11$ & $1.0599 D+06$ \\
\hline 4460 & $5.5313 D+05$ & $1.3095 D+02$ & $1.1406 D+C 2$ & $1.7215 D+C 0$ & $4.5958 D+05$ & $7.5346 \mathrm{D}+03$ & $1.00300-04$ & $8.2947 D-11$ & $9.5226 \mathrm{D}-11$ & $1.0532 \mathrm{D}+06$ \\
\hline 4470 & $5.5444 D+C 5$ & $1.3095 D+02$ & $1.1412 D+02$ & $1.7699 \mathrm{D}+\mathrm{CO}$ & $4.59110+05$ & $7.5256 \mathrm{D}+03$ & $1.0026 \mathrm{D}-04$ & $8.3482 \mathrm{D}-11$ & $9.5794 \mathrm{D}-11$ & $1.0466 \mathrm{D}+06$ \\
\hline 4480 & $5.5574 D+C 5$ & $1.3095 D+02$ & $1.1417 D+02$ & $1.8194 D+00$ & $4.5865 D+05$ & $7.5166 \mathrm{D}+03$ & $1.00230-04$ & $8.4020 D-11$ & $9.6367 D-11$ & $1.0401 D+06$ \\
\hline 4490 & $5.57050+05$ & $1.3095 D+02$ & $1.1423 D+02$ & $1.86990+00$ & $4.5818 D+05$ & $7.5076 \mathrm{D}+03$ & $1.00200-04$ & $8.4562 D-11$ & $9.6943 \mathrm{D}-11$ & $1.0336 D+C 6$ \\
\hline 4500 & $5.5836 \mathrm{D}+05$ & $1.30950+02$ & $1.1428 \mathrm{D}+02$ & $1.92160+00$ & $4.57710+05$ & $7.4987 D+03$ & $1.00160-04$ & $8.5107 D-11$ & $9.7522 \mathrm{D}-11$ & $1.02710+06$ \\
\hline 4510 & $5.5967 D+05$ & $1.3095 D+02$ & $1.14330+02$ & $1.9744 D+00$ & $4.5724 D+05$ & $7.4897 \mathrm{D}+03$ & $1.00130-04$ & $8.5656 D-11$ & $9.81050-11$ & $1.0206 \mathrm{D}+06$ \\
\hline 4520 & $5.6 C 98 D+05$ & $1.3095 D+02$ & 1. $1439 D+02$ & $2.0284 \mathrm{D}+00$ & $4.5677 D+U 5$ & $7.4807 D+03$ & $1.00100-04$ & $8.6209 \mathrm{D}-11$ & $9.8692 \mathrm{D}-11$ & $1.0142 D+06$ \\
\hline 4530 & $5.6229 D+05$ & $1.3095 D+02$ & $1.1444 D+02$ & $2.08350+00$ & $4.5630 D+05$ & $7.4717 \mathrm{D}+03$ & $1.00060-04$ & $8.67650-11$ & $9.9282 \mathrm{D}-11$ & $1.00790+06$ \\
\hline $454 \mathrm{C}$ & $5.6360 D+C 5$ & $1.3095 D+02$ & $1.14490+02$ & $2.1398 \mathrm{D}+00$ & $4.5583 D+05$ & $7.4627 D+03$ & $1.0003 \mathrm{D}-04$ & $8.7325 \mathrm{D}-11$ & $9.98770-11$ & $1.00150+06$ \\
\hline 4550 & $5.6491 D+05$ & $1.3095 D+C 2$ & $1.1455 D+02$ & $2.197 .3 \mathrm{D}+00$ & $4.5536 D+05$ & $7.4537 D+03$ & $9.9995 D-05$ & $8.7888 D-11$ & $1.0047 \mathrm{D}-10$ & $9.9523 D+05$ \\
\hline 4560 & $5.6622 D+05$ & $1.3095 D+02$ & $1.14600+02$ & $2.2561 \mathrm{D}+00$ & $4.5489 D+05$ & $7.4447 D+03$ & $9.99620-05$ & $8.84550-11$ & $1.01080-10$ & $9.88970+05$ \\
\hline 4570 & $5.6753 \mathrm{D}+05$ & $1.3095 \mathrm{D}+02$ & $1.1465 \mathrm{D}+02$ & $2.3160 D+C 0$ & $4.5442 D+05$ & $7.4357 D+03$ & $9.99290-05$ & $6.9027 D-11$ & $1.0168 \mathrm{D}-10$ & $9.8276 \mathrm{D}+05$ \\
\hline 4560 & $5.6884 D+05$ & $1.3095 D+02$ & $1.1470 D+02$ & $2.37730+00$ & $4.539 \in D+05$ & $7.4268 \mathrm{D}+03$ & $9.9895 D-05$ & $8.96020-11$ & $1.0229 D-10$ & $9.7658 D+C 5$ \\
\hline 4590 & $5.7 C 15 D+C 5$ & $1.3095 D+02$ & $1.1476 \mathrm{D}+\mathrm{CO} 2$ & $2.4398 \mathrm{D}+00$ & $4.5349 D+05$ & $7.4178 \mathrm{D}+03$ & $9.9362 D-05$ & $9.01800-11$ & $1.02900-10$ & $9.7043 D+05$ \\
\hline 4600 & $5.71460+05$ & $1.3095 \mathrm{D}+02$ & $1.1481 D+02$ & $2.50360+00$ & $+.5302 D+05$ & $7.4088 D+03$ & $9.9829 D-05$ & $9.0763 \mathrm{D}-11$ & $1.0352 \mathrm{D}-10$ & $9.6432 \mathrm{D}+05$ \\
\hline 4610 & $5.72770+05$ & $1.3095 D+02$ & $1.1486 D+02$ & $2.5687 D+00$ & $4.5255 D+05$ & $7.3998 D+03$ & $9.9796 \mathrm{D}-05$ & $9.1350 \mathrm{D}-11$ & $1.0414 D-10$ & $9.5825 D+05$ \\
\hline 4620 & $5.7408 D+05$ & $1.3095 D+02$ & $1.1492 D+02$ & $2.6352 \mathrm{D}+00$ & $4.52080+05$ & $7.3908 D+03$ & $9.9762 D-05$ & $9.1940 D-11$ & $1.04770-10$ & $9.5221 D+05$ \\
\hline 4630 & $5.75390+0.5$ & $1.3095 D+02$ & $1.1497 D+02$ & $2.7030 \mathrm{D}+00$ & $+.51610+05$ & $7.3818 D+03$ & $9.97290-05$ & $9.25350-11$ & $1.05400-10$ & $9.4621 \mathrm{D}+05$ \\
\hline 4640 & $5.767 C D+O 5$ & $1.3095 D+02$ & $1.1502 D+02$ & $2.7722 \mathrm{D}+\mathrm{CO}$ & $4.5114 D+05$ & $7.3728 D+03$ & $9.9696 \mathrm{D}-05$ & $9.3134 \mathrm{D}-11$ & $1.06030-10$ & $9.40240+05$ \\
\hline 4650 & $5.78010+05$ & $1.3095 D+02$ & $1.1507 \mathrm{D}+02$ & $2.84270+00$ & $4.5067 D+05$ & $7.36390+03$ & $9.96630-05$ & $9.3737 D-11$ & $1.0667 \mathrm{D}-10$ & $9.3431 \mathrm{D}+05$ \\
\hline 4660 & $5.79320+05$ & $1.3095 D+02$ & $1.1512 D+02$ & $2.9147 \mathrm{D}+\mathrm{v} 0$ & $4.50200+05$ & $7.3549 D+03$ & $9.9630 \mathrm{D}-05$ & $9.4344 \mathrm{D}-11$ & $1.07310-10$ & $9.2841 \mathrm{D}+\mathrm{C5}$ \\
\hline 4670 & $5.8063 D+0.5$ & $1.3095 D+02$ & $1.1518 D+02$ & $2.9881 \mathrm{D}+00$ & $1.4974 \mathrm{D}+05$ & $7.3459 \mathrm{D}+03$ & $9.9597 \mathrm{D}-05$ & $9.49550-11$ & $1.0796 \mathrm{D}-10$ & $9.2255 \mathrm{D}+05$ \\
\hline
\end{tabular}


THERMODYNAMIC PBOPERTIES OP LIQUID URANIOH DIOXIDE

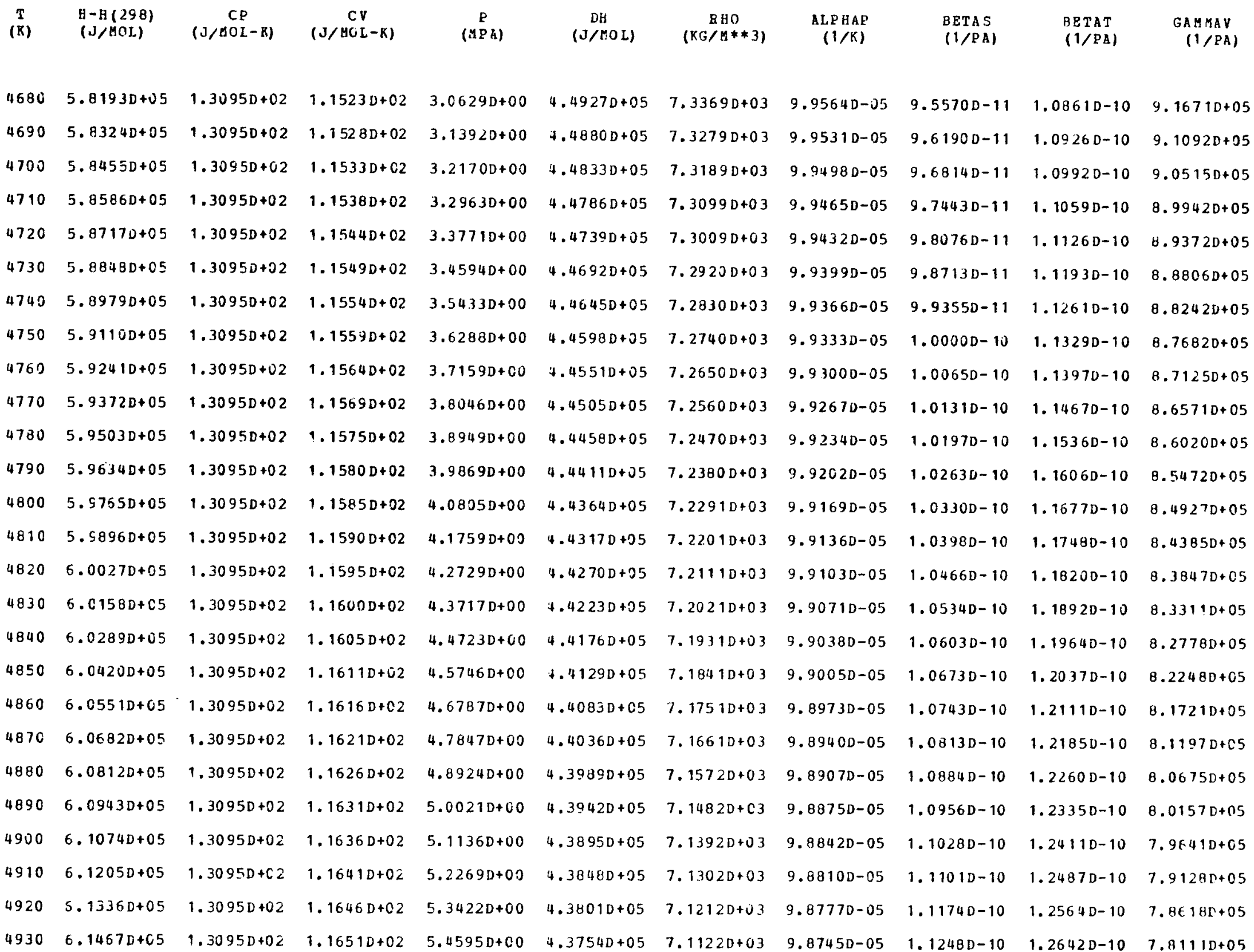


THERKODTAAIC PROPERTIES OF LIQUID URANIOH DIOXIDE

\begin{tabular}{|c|c|c|c|c|c|c|c|c|c|c|}
\hline $\begin{array}{l}T \\
\text { (K) }\end{array}$ & $\begin{array}{l}\mathrm{H}-\mathrm{H}(298) \\
(\mathrm{J} / \mathrm{HCL})\end{array}$ & $\begin{array}{c}C P \\
(J / M O L-K)\end{array}$ & $\begin{array}{c}C V \\
(J / M O L-K)\end{array}$ & $\underset{(\because P A)}{P}$ & $\begin{array}{c}\text { EH } \\
\text { (J/LOL) }\end{array}$ & $\begin{array}{c}\varepsilon \forall 0 \\
(K \in / B * * 3)\end{array}$ & $\begin{array}{r}\text { ALPEAP } \\
(1 / K)\end{array}$ & $\begin{array}{l}\text { BETAS } \\
(1 / \text { A })\end{array}$ & $\begin{array}{l}\text { BETAT } \\
(1 / \text { PA })\end{array}$ & $\begin{array}{l}\text { GAMMAV } \\
(1 / \mathrm{PA})\end{array}$ \\
\hline 4940 & $6.1598 D+05$ & $1.3095 D+02$ & $1.1656 D+02$ & $5.5787 D+00$ & $4.3707 D+05$ & $7.1032 D+03$ & $9.8712 \mathrm{D}-05$ & $1.1322 \mathrm{D}-1 \mathrm{C}$ & $1.27200-10$ & $7.7606 \mathrm{D}+05$ \\
\hline 4950 & $6.1729 D+05$ & $1.3095 D+02$ & $1.16610+02$ & $5.6998 \mathrm{D}+0 \mathrm{CC}$ & $4.3661 D+05$ & $7.0943 \mathrm{D}+03$ & $9.8680 \mathrm{D}-05$ & 1. $1397 \mathrm{D}-10$ & 1. $2798 \mathrm{D}-10$ & $7.7104 \mathrm{D}+05$ \\
\hline 4960 & $6.1660 D+05$ & $1.30950+02$ & $1.1666 \mathrm{D}+02$ & $5.82300+00$ & $4.3614 \mathrm{D}+05$ & $7.08530+03$ & $9.86470-05$ & $1.1473 D-10$ & $1.2877 D-10$ & $7.6605 \mathrm{D}+05$ \\
\hline 4970 & $6.19910+05$ & $1.3095 D+02$ & $1.1672 .0+02$ & $5.9481 \mathrm{D}+00$ & $4.35670+05$ & $7.0763 D+03$ & $9.8615 \mathrm{D}-05$ & $1.1549 D-10$ & $1.29570-10$ & $7.61080+05$ \\
\hline 4980 & $6.2122 D+C 5$ & $1.3095 D+02$ & $1.1677 D+02$ & $6.07530+00$ & $4.3520 D+05$ & $7.0673 D+03$ & $9.8582 \mathrm{D}-05$ & $1.16250-10$ & $1.30370-10$ & $7.56140+05$ \\
\hline 4990 & $6.2253 D+05$ & $1.30950+02$ & $1.1682 D+02$ & $6.20460+00$ & $4.34730+05$ & $7.05830+0.3$ & $9.8550 \mathrm{D}-05$ & $1.17030-10$ & $1.3118 D-10$ & $7.51230+C 5$ \\
\hline 5000 & $6.2384 D+05$ & $1.3095 D+02$ & 1. $1687 D+02$ & $6.3359 D+C 0$ & $4.34260+05$ & $7.04930+C 3$ & $9.8518 D-05$ & $1.1780 D-10$ & $1.32000-10$ & $7.4634 D+05$ \\
\hline 5010 & $6.2515 D+05$ & $1.3095 D+C 2$ & $1.1692 \mathrm{D}+02$ & $6.46930+00$ & $4.33790+05$ & $7.0403 D+03$ & $9.84850-05$ & $1.1859 \mathrm{D}-10$ & $1.3282 D-10$ & $7.4148 D+C 5$ \\
\hline 5020 & $6.2646 D+05$ & $1.3095 D+02$ & $1.1697 \mathrm{D}+02$ & $6.6049 D+C 0$ & $4.3332 D+05$ & $7.0313 D+03$ & $9.8453 D-05$ & $1.1938 \mathrm{D}-10$ & 1. $3365 \mathrm{D}-10$ & $7.36640+05$ \\
\hline 5030 & $6.27770+05$ & $1.3095 D+02$ & $1.1702 D+02$ & $6.7425 D+00$ & $4.3285 D+05$ & $7.02240+03$ & $9.84210-05$ & $1.20180-10$ & $1.34480-10$ & $7.31830+05$ \\
\hline 5040 & $6.2908 D+05$ & $1.3095 D+02$ & $1.1707 D+02$ & $6.882 .3 \mathrm{D}+00$ & $4.3238 D+05$ & $7.0134 \mathrm{D}+03$ & $9.8388 D-05$ & $1.2098 D-10$ & $1.35330-10$ & $7.27050+05$ \\
\hline 5050 & $6.3039 D+05$ & $1.3095 D+02$ & $1.1712 \mathrm{D}+02$ & 7. $C 243 D+00$ & $4.31920+05$ & $7.00440+03$ & $9.8356 \mathrm{D}-05$ & $1.21790-10$ & $1.3617 D-10$ & $7.222 .0+05$ \\
\hline 5060 & $6.31700+C 5$ & $1.3095 D+02$ & $1.1717 D+02$ & $7.1685 D+00$ & $4.3145 D+05$ & $6.9954 D+03$ & $9.83240-05$ & $1.22610-10$ & 1. $37030-10$ & $7.1755 D+05$ \\
\hline 5070 & $6.3301 D+05$ & $1.30950+02$ & $1.1722 \mathrm{D}+02$ & $7.31490+C O$ & $4.3098 D+05$ & $6.9864 D+03$ & $9.82920-05$ & $1.23430-10$ & $1.3789 D-10$ & $7.1284 D+C 5$ \\
\hline 5080 & $6.3431 D+05$ & $1.3095 D+02$ & $1.1727 \mathrm{D}+02$ & $7.4635 \mathrm{D}+00$ & $4.3051 D+05$ & $6.97740+03$ & $9.8259 \mathrm{D}-05$ & $1.2426 D-10$ & $1.3875 D-10$ & $7.08150+05$ \\
\hline 5090 & $6.3562 D+C 5$ & $1.3095 D+02$ & $1.17320+02$ & $7.6144 \mathrm{D}+\mathrm{CO}$ & $4.3004 D+05$ & $6.9684 \mathrm{D}+03$ & $9.8227 D-05$ & $1.25100-10$ & $1.3963 D-10$ & $7.03490+05$ \\
\hline 5100 & $6.3693 D+05$ & $1.3095 D+02$ & $1.17370+02$ & $7.7676 \mathrm{D}+\mathrm{CO}$ & $4.2957 D+05$ & $6.9595 \mathrm{D}+03$ & $9.8195 D-05$ & $1.25940-10$ & $1.40510-10$ & $6.98850+05$ \\
\hline 5110 & $6.3824 D+05$ & $1.3095 D+C 2$ & $1.1742 \mathrm{D}+02$ & $7.92300+00$ & $4.29100+35$ & $6.95050+03$ & $9.81630-05$ & $1.2679 D-10$ & $1.41400-10$ & $6.94230+05$ \\
\hline 5120 & $6.3955 D+05$ & 1. $3095 D+02$ & $1.1747 D+C 2$ & E.C. $B C 8 D+C O$ & $4.28630+05$ & $6.94150+03$ & $9.81310-05$ & $1.2765 D-10$ & 1. $4229 D-10$ & $6.8964 D+05$ \\
\hline 5130 & $6.4086 D+05$ & $1.3095 \mathrm{D}+02$ & $1.17520+02$ & $8.2408 D+00$ & $4.2816 D+05$ & $6.9325 D+03$ & $9.8099 D-05$ & $1.28510-10$ & $1.43190-10$ & $6.85070+05$ \\
\hline $514 \mathrm{C}$ & $6.4217 D+C 5$ & $1.3095 \mathrm{D}+02$ & $1.17570+02$ & $8.4033 D+00$ & $4.2770 D+05$ & $6.9235 D+03$ & $9.8067 D-05$ & $1.2938 D-10$ & $1.44100-10$ & $6.80530+05$ \\
\hline 5150 & $6.4348 D+05$ & $1.3095 D+02$ & $1.1762 \mathrm{D}+02$ & $8.5681 \mathrm{D}+00$ & $4.27230+05$ & $6.9145 D+03$ & $9.80350-05$ & $1.3026 D-10$ & $1.4502 D-10$ & $6.7601 D+05$ \\
\hline 5160 & $6.4479 D+05$ & $1.3095 D+02$ & $1.1767 D+02$ & $8.7353 D+00$ & $4.26760+05$ & $6.9055 D+03$ & $9.80030-05$ & $1.3115 D-10$ & $1.4594 \mathrm{D}-10$ & $6.7151 \mathrm{D}+05$ \\
\hline 5170 & $6.46100+05$ & 1. $30955+02$ & $1.17720+02$ & $8.90490+00$ & $4.2629 D+05$ & $6.8965 D+03$ & $9.79710-05$ & $1.3204 D-10$ & $1.4688 D-10$ & $6.67030+05$ \\
\hline 5180 & $6.47410+C 5$ & $1.20950+02$ & $1.1777 D+02$ & $9.07690+00$ & $4.2582 \mathrm{D}+0 \mathrm{~S}$ & $6.88760+03$ & $9.79390-05$ & $1.3294 \mathrm{D}-10$ & 1. $4781 \mathrm{D}-10$ & $6.62580+05$ \\
\hline 519 & $6.48720+05$ & $1.3095 D+02$ & $1.17820+02$ & $9.25140+00$ & $4.25350+05$ & $6.8786 D+03$ & $9.79070-05$ & $1.3385 D-10$ & $1.4876 \mathrm{D}-10$ & $6.5815 D+05$ \\
\hline
\end{tabular}


THERMODYNAMIC PROPERTIES OF LIQOID URANIUM DIOXIDE

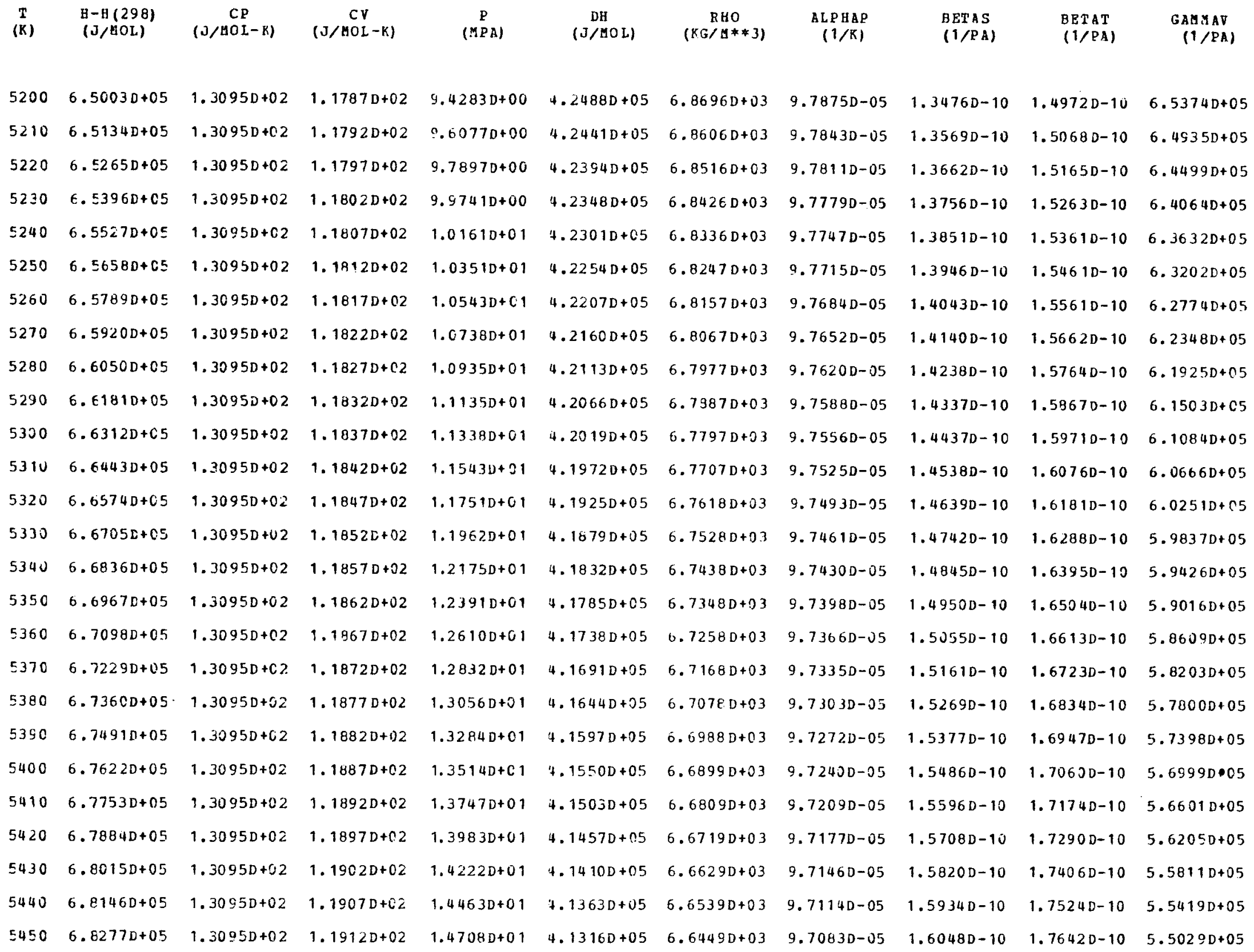


THEFMODYHAMIC FROPERTIES OF LIQUID URANIUA DIOXIDE

\begin{tabular}{|c|c|c|c|c|c|c|c|c|c|c|}
\hline $\begin{array}{l}T \\
(\mathrm{R})\end{array}$ & $\begin{array}{l}B-H(298) \\
(J / M O L)\end{array}$ & $\begin{array}{c}C P \\
(J / H C L-K)\end{array}$ & $\begin{array}{c}C V \\
(J / M O L-K)\end{array}$ & $\stackrel{P}{(M P A)}$ & $\begin{array}{c}\text { DHI } \\
\text { (J/MOL) }\end{array}$ & 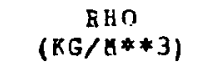 & $\begin{array}{c}\text { ALFHAP } \\
(1 / K)\end{array}$ & $\begin{array}{l}\text { BETAS } \\
(1 / \mathrm{PA})\end{array}$ & $\begin{array}{l}\text { BETAT } \\
\text { (1/PA) }\end{array}$ & $\begin{array}{l}\text { GAMMAV } \\
\text { (1/PA) }\end{array}$ \\
\hline 5460 & $6.8408 D+05$ & $1.3095 D+02$ & $1.1917 \mathrm{D}+02$ & $1.4955 D+01$ & $4.1269 D+05$ & $6.6359 D+03$ & $9.70510-05$ & $1.6164 D-10$ & $1.7762 \mathrm{D}-10$ & $5.46400+05$ \\
\hline 5470 & $6.85390+05$ & $1.3095 \mathrm{D}+\mathrm{C} 2$ & 1. $1922 \mathrm{D}+02$ & $1.5206 \mathrm{D}+01$ & $4.1222 D+05$ & $6.6270 \mathrm{D}+03$ & $9.70200-05$ & $1.62810-10$ & $1.7883 D-10$ & $5.4254 D+05$ \\
\hline 5480 & $6.8669 D+05$ & $1.3095 D+02$ & $1.1927 D+02$ & $1.5459 D+01$ & $7.1175 D+05$ & $6.6180 \mathrm{D}+03$ & $9.69890-05$ & $1.63980-10$ & $1.8005 \mathrm{D}-10$ & $5.386 .0 \mathrm{D}+0.5$ \\
\hline 5490 & $6.8800 D+05$ & $1.3095 D+02$ & $1.1932 D+02$ & $1.5716 \mathrm{D}+01$ & $4.1128 D+05$ & $6.6090 D+03$ & $9.6957 D-05$ & $1.6517 \mathrm{D}-10$ & $1.8128 \mathrm{D}-10$ & $5.3486 \mathrm{D}+05$ \\
\hline 5500 & $6.89310+05$ & $1.3095 D+02$ & $1.1937 \mathrm{D}+\mathrm{C} 2$ & $1.5975 D+01$ & $4.10810+05$ & $6.6000 D+03$ & $9.69260-05$ & $1.6637 \mathrm{D}-10$ & $1.8252 \mathrm{D}-10$ & $5.31050+05$ \\
\hline 5510 & $6.90620+05$ & $1.3095 D+02$ & 1. $1942 \mathrm{D}+02$ & 1. $€ 2380+01$ & $4.1035 D+05$ & $6.59100+03$ & $9.6895 \mathrm{D}-05$ & $1.6759 D-10$ & $1.8377 \mathrm{D}-10$ & $5.2725 D+05$ \\
\hline 5520 & $6.9193 D+05$ & $1.30950+02$ & $1.19470+02$ & $1.6503 \mathrm{D}+01$ & $4.0988 D+05$ & $6.5820 D+03$ & $9.6863 D-05$ & $1.68810-10$ & $1.85040-10$ & $5.2348 D+05$ \\
\hline 5530 & $6.9324 D+05$ & $1.3095 D+02$ & 1. $1952 \mathrm{D}+02$ & $1.6772 D+01$ & $4.09410+05$ & $6.5730 D+03$ & $9.6832 \mathrm{D}-05$ & $1.7005 D-10$ & $1.8632 \mathrm{D}-10$ & $5.1972 D+05$ \\
\hline 5540 & $6.9455 D+05$ & $1.3095 D+02$ & $1.1957 D+02$ & $1.70430+01$ & $4.0894 D+05$ & $6.5640 D+03$ & $9.68010-05$ & $1.71300-10$ & $1.8761 \mathrm{D}-10$ & 5. $1598 \mathrm{D}+05$ \\
\hline 5550 & $6.9586 D+C 5$ & $1.3095 D+02$ & $1.19620+02$ & $1.7318 \mathrm{D}+01$ & $4.0847 D+05$ & $6.5551 \mathrm{D}+03$ & $9.6770 D-05$ & $1.7256 \mathrm{D}-10$ & $1.8891 D-10$ & $5.1225 D+05$ \\
\hline 5560 & $6.9717 \mathrm{D}+05$ & $1.3095 D+02$ & $1.19670+02$ & $1.7596 \mathrm{D}+01$ & $4.08000+05$ & $6.5461 \mathrm{D}+03$ & $9.67390-05$ & $1.7384 \mathrm{D}-10$ & $1.9023 \mathrm{D}-10$ & $5.08550+05$ \\
\hline 5570 & $6.9848 D+05$ & 1. $3095 \mathrm{D}+02$ & $1.1972 D+02$ & $1.7876 \mathrm{D}+01$ & $4.0753 D+05$ & $6.5371 \mathrm{D}+03$ & $9.6707 D-05$ & $1.7512 \mathrm{D}-10$ & $1.9155 \mathrm{D}-10$ & $5.0486 D+05$ \\
\hline 5580 & $6.99790+C 5$ & $1.30950+02$ & 1. $1977 \mathrm{D}+02$ & $1.8160 D+01$ & $4.0706 D+05$ & $6.5281 D+03$ & $9.6676 \mathrm{D}-05$ & $1.7642 D-10$ & $1.9290 \mathrm{D}-10$ & $5.0118 D+05$ \\
\hline 5590 & $7.01100+05$ & 1. $3095 \mathrm{D}+02$ & $1.19820+02$ & $1.8448 D+01$ & $4.06590+05$ & $6.5191 D+03$ & $9.6645 \mathrm{D}-05$ & $1.7774 \mathrm{D}-10$ & $1.9425 \mathrm{D}-10$ & $4.9753 D+05$ \\
\hline 5600 & 7. $C 2410+05$ & $1.3095 D+C 2$ & $1.1987 D+02$ & $1.87380+01$ & $4.0612 D+05$ & $6.51010+03$ & $9.5614 \mathrm{D}-05$ & $1.7906 \mathrm{D}-10$ & $1.9562 \mathrm{D}-10$ & $4.9389 D+05$ \\
\hline 5610 & $7.03720+05$ & $1.3095 D+02$ & $1.1992 D+02$ & $1.90310+01$ & $4.0566 \mathrm{D}+05$ & $6.5011 \mathrm{D}+03$ & $9.6583 \mathrm{D}-05$ & $1.80400-10$ & $1.9700 \mathrm{D}-10$ & $4.9026 D+05$ \\
\hline 5620 & $7.0503 D+C 5$ & $1.3095 D+02$ & $1.1997 \mathrm{D}+\mathrm{C} 2$ & $1.9328 D+01$ & $4.05190+05$ & $6.492 .2 \mathrm{D}+03$ & $9.6552 \mathrm{D}-05$ & $1.81760-10$ & $1.9840 \mathrm{D}-10$ & $4.8666 \mathrm{D}+05$ \\
\hline 5630 & $7.06340+05$ & $1.30950+n 2$ & $1.2002 D+C 2$ & $1.9628 D+01$ & $4.2472 D+05$ & $6.4832 .0+03$ & $9.65210-05$ & $1.8313 D-10$ & $1.9981 \mathrm{D}-10$ & $4.8307 D+05$ \\
\hline 5640 & $7.0765 D+05$ & $1.3095 D+02$ & $1.20070+02$ & $1.99310+01$ & $4.0425 D+05$ & $6.47420+03$ & $9.64900-05$ & $1.84510-10$ & $2.01230-10$ & $4.79490+25$ \\
\hline 5650 & $7.08960+05$ & $1.3095 D+02$ & $1.2012 . D+02$ & $2.02370+01$ & $4.0378 D+0.5$ & $6.4652 \mathrm{D}+03$ & $9.6459 \mathrm{D}-05$ & $1.85900-10$ & $2.02670-10$ & $4.7504 D+05$ \\
\hline 5660 & $7.1027 D+C 5$ & $1.3095 D+02$ & $1.20170+02$ & $2.05460+01$ & $4.03310+05$ & $6.4562 D+03$ & $9.6428 D-05$ & $1.8732 D-10$ & $2.0413 \mathrm{D}-10$ & $4.7239 D+05$ \\
\hline 5670 & $7.11580+05$ & 1. $30.95 D+02$ & $1.2022 \mathrm{D}+\mathrm{C} 2$ & $2.08590+01$ & $4.02840+05$ & $6.4472 D+03$ & $9.63970-05$ & $1.8874 D-1 C$ & $2.0559 D-10$ & $4.6887 \mathrm{D}+05$ \\
\hline 5680 & $7.1288 D+05$ & $1.3095 \mathrm{D}+02$ & $1.2027 D+02$ & $2.1175 D+C 1$ & $4.0237 D+05$ & $6.43820+03$ & $9.63660-05$ & $1.90180-10$ & $2.07080-10$ & $4.65360+05$ \\
\hline 5690 & $7.14190+0.5$ & 1. $3095 D+02$ & $1.2032 D+02$ & $2.1494 D+C 1$ & $4.01900+05$ & $6.4292 \mathrm{D}+03$ & $9.63350-05$ & $1.91640-10$ & $2.08580-10$ & $4.61860+05$ \\
\hline 5700 & $7.155 C D+05$ & $1.3095 D+02$ & $1.2037 D+02$ & $2.1817 D+01$ & $4.2144 D+05$ & $6.42030+03$ & $9.6304 D-05$ & $1.9311 \mathrm{D}-10$ & $2.1009 D-10$ & $4.58390+05$ \\
\hline 710 & 7. $16810+C 5$ & $1.3095 \mathrm{D}+02$ & $1.2042 \mathrm{D}+02$ & $2.21430+01$ & $4.0097 D+05$ & $6.41130+03$ & $9.62730-05$ & $1.9460 \mathrm{D}-10$ & $2.1162 \mathrm{D}-10$ & $4.54920+05$ \\
\hline
\end{tabular}


THERUODIHAMIC RROREETTES OF LIQUID URANIOA DIOXIDE

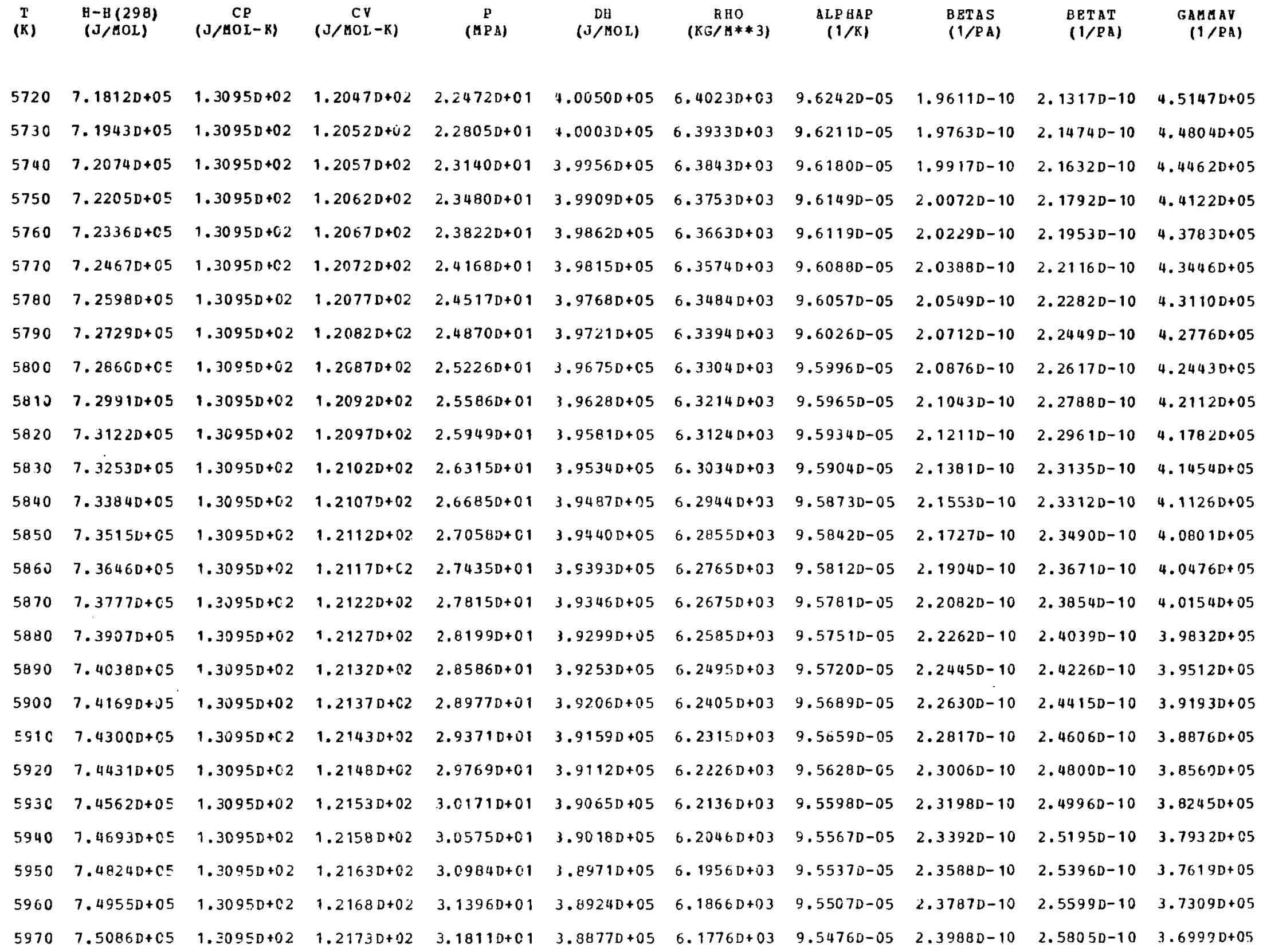


THERMODINABIC PBOPEETIES OP LIOOID URANIUM DIOYIDE

\begin{tabular}{|c|c|c|c|c|c|c|c|c|c|c|}
\hline $\begin{array}{c}T \\
(K)\end{array}$ & $\begin{array}{l}B-H(298) \\
(3 / 80 L)\end{array}$ & $\begin{array}{c}C P \\
(J / \Delta C I-x)\end{array}$ & $\begin{array}{c}C V \\
(J / M O L-K)\end{array}$ & $\stackrel{F}{(M P A)}$ & $\begin{array}{c}\mathrm{DH} \\
(\mathrm{J} / \mathrm{MOL})\end{array}$ & $\begin{array}{c}\text { RHO } \\
(K G / H * * 3)\end{array}$ & $\begin{array}{c}\text { ALPUAP } \\
(1 / K)\end{array}$ & $\begin{array}{l}\text { BETAS } \\
(1 / P A)\end{array}$ & $\begin{array}{l}\text { B ETAT } \\
(1 / \text { PA) }\end{array}$ & $\begin{array}{l}\text { GAUMAV } \\
(1 / P A)\end{array}$ \\
\hline 5980 & $7.5217 D+05$ & $1.3095 D+02$ & $1.2178 D+02$ & 3. $2231 \mathrm{D}+01$ & $3.8831 D+C 5$ & $6.1686 D+03$ & $9.54460-05$ & $2.4192 \mathrm{D}-10$ & $2.6013 D-10$ & $3.6691 D+05$ \\
\hline 5990 & $7.5348 D+05$ & $1.3095 D+02$ & $1.2183 \mathrm{D}+02$ & $3.2653 D+01$ & $3.87840+05$ & $6.1596 D+03$ & $9.5416 \mathrm{D}-05$ & $2.4399 D-10$ & $2.6224 D-10$ & $3.63840+05$ \\
\hline 6000 & $7.5479 D+05$ & $1.3095 D+02$ & $1.21880+02$ & $3.30800+01$ & $3.8737 D+05$ & $6.1507 D+03$ & $9.53850-05$ & $2.4608 D-10$ & $2.6438 \mathrm{D}-10$ & $3.60790+05$ \\
\hline
\end{tabular}


B- 1

TABULATED THERMODYNAMIC PROPERTIES

IN CGS UNITS 
THEA $O$ ODNAMIC PROPEETIES OF SOLID OBANIUA DIOXIDE

\begin{tabular}{|c|c|c|c|c|c|c|c|c|c|c|}
\hline $\begin{array}{c}T \\
(K)\end{array}$ & $\begin{array}{c}H-H(298) \\
(J / G)\end{array}$ & $\begin{array}{c}C P \\
(J / G-R)\end{array}$ & $\begin{array}{c}C \nabla \\
(J / G-K)\end{array}$ & $\begin{array}{c}P \\
\text { (ATM) }\end{array}$ & $\begin{array}{l}\text { RHO } \\
(G / C C)\end{array}$ & $\begin{array}{c}\text { ALPHAP } \\
(1 / K)\end{array}$ & $\begin{array}{l}\text { BETAS } \\
(1 / \text { ATU })\end{array}$ & $\begin{array}{c}\text { BETAT } \\
\text { (1/ATA) }\end{array}$ & $\begin{array}{l}\text { GAMAAY } \\
\text { (ATM/K) }\end{array}$ & \\
\hline 298 & 0.0 & $2.3552 \mathrm{D}-01$ & 2. $3293 D-01$ & 0.0 & $1.09700+01$ & $2.17110-05$ & $4.96370-07$ & $5.01880-07$ & $4.32590+01$ & \\
\hline 300 & $4.36370-01$ & $2.3623 \mathrm{D}-01$ & $2.3362 \mathrm{D}-01$ & 0.0 & $1.09700+01$ & $2.1739 \mathrm{D}-05$ & $4.96480-07$ & $5.0202 D-07$ & $4.33240+01$ & \\
\hline 310 & $2.8175 D+00$ & $2.39950-01$ & $2.3722 \mathrm{D}-01$ & 0.0 & $1.0967 D+01$ & $2.18930-05$ & $4.97040-07$ & $5.02760-07$ & $4.3546 D+01$ & \\
\hline 320 & $5.23450+00$ & $2.4340 \mathrm{D}-01$ & $2.4055 D-01$ & 0.0 & $1.0965 D+01$ & $2.20480-05$ & $4.97600-07$ & $5.03510-07$ & $4.3788 D+01$ & \\
\hline 3.30 & $7.68480+0 C$ & $2.4662 \mathrm{D}-01$ & $2.4364 \mathrm{D}-01$ & 0.0 & $1.0962 D+01$ & $2.22020-05$ & $4.9817 D-07$ & $5.04270-07$ & $4.40280+01$ & \\
\hline 340 & $1.0166 \mathrm{D}+01$ & $2.4962 \mathrm{D}-01$ & $2.4651 D-01$ & 0.0 & $1.09600+01$ & $2.2356 \mathrm{D}-05$ & $4.98740-07$ & $5.0503 \mathrm{D}-07$ & $4.42670+01$ & \\
\hline $35 \mathrm{C}$ & $1.2676 \mathrm{D}+01$ & $2.5242 \mathrm{D}-01$ & $2.49180-01$ & 0.0 & $1.0958 D+01$ & $2.2511 \mathrm{D}-0.5$ & $4.99310-07$ & $5.05810-07$ & $4.4505 D+01$ & \\
\hline 360 & $1.52140+01$ & $2.5504 \mathrm{D}-01$ & $2.5166 \mathrm{D}-01$ & 0.0 & $1.0955 D+01$ & $2.2666 \mathrm{D}-05$ & $4.9988 D-07$ & $5.0659 D-07$ & $0.4742 D+01$ & \\
\hline $37 \mathrm{C}$ & $1.7777 D+01$ & $2.57500-01$ & $2.53990-01$ & 0.0 & $1.0953 \mathrm{D}+01$ & $2.2821 \mathrm{D}-05$ & $5.0045 \mathrm{D}-07$ & $5.0737 \mathrm{D}-07$ & $4.49780+01$ & \\
\hline 380 & $2.03630+01$ & $2.59810-01$ & $2.5616 \mathrm{D}-01$ & 0.0 & $1.0950 D+01$ & $2.2976 \mathrm{D}-0.5$ & $5.01020-07$ & $5.08170-07$ & $4.52130+01$ & \\
\hline $39 \mathrm{C}$ & $2.29730+01$ & $2.6199 \mathrm{D}-01$ & $2.5819 \Gamma-01$ & 0.0 & $1.0948 D+01$ & $2.31310-05$ & $5.0160 D-07$ & $5.0897 \mathrm{D}-07$ & $4.5447 D+01$ & $\varpi$ \\
\hline 400 & $2.5603 D+01$ & $2.6404 \mathrm{D}-01$ & $2.6010 \mathrm{D}-01$ & $3.6141 \mathrm{D}-70$ & $1.0945 D+01$ & $2.3287 \mathrm{D}-05$ & $5.0217 D-07$ & $5.0978 D-07$ & $4.56800+01$ & \\
\hline 410 & $2.8253 \mathrm{D}+01$ & $2.6597 D-01$ & $2.61890-01$ & $2.9212 \mathrm{D}-68$ & $1.0943 D+01$ & $2.3442 \mathrm{D}-05$ & $5.0275 D-07$ & $5.1059 D-07$ & $4.5912 D+01$ & \\
\hline 420 & $3.0922 D+01$ & $2.6780 \mathrm{D}-01$ & $2.6357 \mathrm{D}-01$ & $1.9155 D-66$ & $1.0940 \mathrm{n}+01$ & 2. $3598 D-05$ & $5.0333 \mathrm{D}-07$ & $5.11+2 \mathrm{E}-07$ & $4.6142 D+01$ & \\
\hline 430 & $3.36090+01$ & $2.6954 \mathrm{D}-01$ & $2.6515 D-v 1$ & $1.03400-64$ & $1.0938 \mathrm{D}+01$ & $2.3754 D-05$ & $5.03910-07$ & $5.1225 \mathrm{D}-07$ & $4.6372 \mathrm{D}+01$ & \\
\hline 440 & $3.6312 \mathrm{D}+01$ & $2.71180-01$ & $2.6664 \mathrm{D}-01$ & $4.6559 D-63$ & $1.0935 D+01$ & $2.39100-05$ & $5.0449 D-07$ & $5.1308 D-07$ & $4.6601 \mathrm{D}+01$ & \\
\hline $45 C$ & $3.90320+01$ & $2.7275 \mathrm{D}-01$ & $2.6805 \mathrm{D}-01$ & $1.7701 \mathrm{D}-61$ & $1.0933 \mathrm{D}+01$ & $2.40660-05$ & $5.0507 \mathrm{D}-07$ & $5.13930-07$ & $4.6829 n+01$ & \\
\hline 460 & $4.1767 D+01$ & $2.7424 D-01$ & $2.69380-01$ & $5.7452 \mathrm{D}-60$ & $1.09300+01$ & $2.4223 \mathrm{D}-05$ & $5.0565 \mathrm{D}-07$ & $5.1+780-07$ & 4. $7055 D+01$ & \\
\hline $47 \mathrm{C}$ & $4.4517 D+01$ & $2.7565 \mathrm{D}-01$ & $2.7063 \mathrm{D}-01$ & $1.6080 D-58$ & $1.0927 D+01$ & $2.43800-05$ & $5.0624 D-07$ & $5.15640-07$ & $4.72910+01$ & \\
\hline 480 & $4.7280 D+01$ & $2.7701 \mathrm{D}-01$ & $2.7182 \mathrm{D}-\mathrm{C} 1$ & $3.91740-57$ & $1.0925 D+01$ & $2.4536 \mathrm{D}-05$ & $5.0683 \mathrm{D}-07$ & $5.16500-07$ & 4. $7505 D+01$ & \\
\hline 490 & $5.0056 D+01$ & $2.78300-C 1$ & $2.7294 D-01$ & $8.37730-56$ & $1.09220+01$ & $2.4693 \mathrm{D}-05$ & $5.07410-07$ & $5.17370-07$ & $4.77280+01$ & \\
\hline 500 & $5.2846 \mathrm{D}+01$ & $2.7954 D-01$ & $2.7401 \mathrm{D}-01$ & $1.58490-54$ & $1.0919 D+01$ & $2.4851 \mathrm{D}-05$ & $5.08000-07$ & $5.1825 D-07$ & $4.79510+01$ & \\
\hline 510 & $5.56470+01$ & $2.8073 D-C 1$ & $2.7502 \mathrm{D}-01$ & $2.67190-53$ & $1.09170+131$ & $2.5008 D-05$ & $5.0859 D-07$ & $5.1914 D-07$ & $4.81720+01$ & \\
\hline 520 & $5.84600+01$ & $2.61870-01$ & $2.75990-01$ & $4.0407 D-52$ & $1.0914 D+01$ & $2.51650-05$ & $5.0918 D-07$ & $5.20030-07$ & $4.83920+01$ & \\
\hline 5.30 & $6.12840+01$ & $2.82960-01$ & $2.70900-01$ & $5.5155 D-51$ & $1.09110+01$ & $2.5323 \mathrm{D}-05$ & $5.09780-07$ & $5.20930-07$ & $4.86110+01$ & \\
\hline 540 & $6.41190+01$ & $2.84010-01$ & $2.7777 \mathrm{D}-0.1$ & $6.8339 D-50$ & $1.0908 D+01$ & $2.5481 \mathrm{D}-05$ & $5.10370-07$ & $5.2184 \mathrm{D}-07$ & $4.88290+01$ & \\
\hline
\end{tabular}




\begin{tabular}{|c|c|c|c|c|c|c|c|c|c|}
\hline $\begin{array}{c}T \\
(K)\end{array}$ & $\begin{array}{c}H-H(298) \\
(J / G)\end{array}$ & $\begin{array}{c}C P \\
(J / G-K)\end{array}$ & $\begin{array}{c}C V \\
(J / G-K)\end{array}$ & $\begin{array}{c}P \\
(\mathrm{ATE})\end{array}$ & $\begin{array}{l}\text { RHO } \\
(\mathrm{G} / \mathrm{CC})\end{array}$ & $\begin{array}{l}\text { A LPHAP } \\
(1 / K)\end{array}$ & $\begin{array}{c}\text { BETAS } \\
(1 / \text { ATH })\end{array}$ & $\begin{array}{c}\text { ВЕТАT } \\
\text { (1/ATM) }\end{array}$ & $\begin{array}{l}\text { GAMMAV } \\
(\text { ATM } / K)\end{array}$ \\
\hline 550 & $6.6964 D+01$ & $2.8502 D-01$ & $2.7860 \mathrm{D}-01$ & $7.7268 D-49$ & $1.0906 \mathrm{D}+01$ & $2.5639 \mathrm{D}-05$ & $5.1097 \mathrm{D}-07$ & $5.22750-07$ & $4.9046 D+01$ \\
\hline 560 & $6.98200+01$ & $2.8600 D-01$ & $2.79390-01$ & $8.0115 D-48$ & $1.0903 D+01$ & $2.57970-05$ & $5.1156 D-07$ & $5.23670-07$ & $4.9261 D+01$ \\
\hline 570 & $7.26840+01$ & $2.8694 \mathrm{D}-01$ & $2.8014 \mathrm{D}-01$ & $7.6523 \mathrm{D}-47$ & $1.09000+j 1$ & $2.5955 \mathrm{D}-05$ & $5.1216 D-07$ & $5.24600-07$ & $4.9476 \mathrm{D}+01$ \\
\hline 580 & $7.55580+01$ & $2.87850-01$ & $2.8086 \mathrm{D}-01$ & $6.7619 D-46$ & $1.0897 D+01$ & $2.61140-.05$ & $5.1276 \mathrm{D}-07$ & $5.25540-07$ & $4.96890+01$ \\
\hline 590 & $7.84410+01$ & $2.887 .3 D-01$ & $2.81540-01$ & $5.5497 D-45$ & $1.08940+21$ & $2.62720-05$ & $5.1336 \mathrm{D}-07$ & $5.26480-07$ & $4.99020+01$ \\
\hline 600 & $E .13330+01$ & $2.89590-01$ & $2.82190-01$ & $4.2462 \mathrm{D}-44$ & $1.08920+01$ & $2.64310-05$ & $5.13970-07$ & $5.2743 D-37$ & $5.0113 D+01$ \\
\hline 610 & e. $42330+01$ & $2.90410-01$ & $2.8282 D-01$ & $3.0392 \mathrm{D}-4.3$ & $1.0889 D+01$ & $2.6590 \mathrm{D}-05$ & $5.14570-07$ & $5.28390-07$ & $5.03230+01$ \\
\hline $62 \mathrm{C}$ & $E .71410+01$ & $2.91210-01$ & $2.83410-01$ & $2.0414 \mathrm{D}-42$ & $1.0886 \mathrm{D}+01$ & $2.6749 D-05$ & $5.15180-07$ & $5.29360-07$ & $5.05310+01$ \\
\hline 630 & $9.00570+01$ & $2.91990-01$ & $2.8398 \mathrm{D}-01$ & $1.2908 D-41$ & $1.08 B 30+01$ & $2.69080-35$ & $5.1579 D-07$ & $5.30330-07$ & $5.07390+01$ \\
\hline 640 & $9.29810+01$ & $2.9275 \mathrm{D}-01$ & $2.8453 \mathrm{D}-01$ & $7.7046 D-41$ & $1.08800+01$ & $2.7068 D-05$ & $5.1639 D-07$ & $5.31310-07$ & $5.0945 D+01$ \\
\hline 650 & $9.59120+01$ & $2.9348 D-01$ & $2.8505 D-C 1$ & $4.3528 D-40$ & $1.0877 D+01$ & $2.7227 \mathrm{D}-05$ & $5.1700 D-07$ & $5.3230 \mathrm{D}-07$ & $5.1151 D+01$ \\
\hline 660 & S. $88500+01$ & $2.94200-01$ & $2.8555 \mathrm{D}-01$ & $2.3335 \mathrm{D}-39$ & $1.08740+01$ & $2.73870-05$ & $5.1762 D-07$ & $5.3329 \mathrm{D}-07$ & $5.1355 D+01$ \\
\hline 670 & $1.01800+02$ & $2.9490 D-01$ & $2.8603 \mathrm{D}-01$ & 1. $1898 \mathrm{D}-38$ & $1.08710+01$ & $2.75470-05$ & $5.1823 \mathrm{D}-07$ & $5.34300-37$ & $5.1558 D+01$ \\
\hline 680 & $1.0475 D+02$ & $2.9558 \mathrm{D}-01$ & $2.8649 \mathrm{D}-01$ & $5.7825 D-38$ & $1.08680+01$ & $2.7707 D-05$ & $5.1884 D-07$ & $5.35310-07$ & $5.1759 \mathrm{D}+01$ \\
\hline 690 & $1.0771 D+02$ & $2.9624 \mathrm{D}-01$ & $2.86930-01$ & $2.6845 D-37$ & $1.08650+01$ & $2.7867 D-05$ & $5.1946 \mathrm{D}-07$ & $5.36330-07$ & 5. $1960 D+01$ \\
\hline 700 & $1.1067 D+02$ & $2.9689 \mathrm{D}-01$ & $2.8735 \mathrm{D}-01$ & $1.1928 \mathrm{D}-36$ & $1.08620+01$ & $2.8028 D-05$ & $5.20080-07$ & $5.3735 D-07$ & $5.21590+01$ \\
\hline 710 & $1.1365 D+02$ & $2.9753 D-01$ & $2.87750-01$ & $5.0819 D-36$ & $1.08590+11$ & $2.8188 \mathrm{D}-05$ & $5.2069 D-07$ & $5.3839 \mathrm{D}-07$ & $5.2357 D+01$ \\
\hline 720 & $1.1662 D+02$ & $2.98150-01$ & $2.8813 D-01$ & $2.0797 D-35$ & $1.08560+01$ & $2.83490-05$ & $5.2131 \mathrm{D}-07$ & $5.3943 \mathrm{D}-07$ & $5.25540+01$ \\
\hline 730 & $1.1 \subseteq 610+02$ & $2.9875 \mathrm{D}-01$ & $2.8850 \mathrm{D}-01$ & 8. $18850-35$ & $1.08530+01$ & $2.85100-05$ & $5.21940-07$ & $5.40480-07$ & $5.27500+C 1$ \\
\hline 740 & $1.22600+02$ & $2.99350-01$ & $2.88860-01$ & $3.1069 \mathrm{D}-34$ & $1.0850 \mathrm{D}+01$ & $2.8671 \mathrm{D}-05$ & $5.2256 \mathrm{D}-07$ & $5.4154 D-07$ & $5.2944 D+01$ \\
\hline 750 & 1. $2560 \mathrm{D}+02$ & $2.9993 \mathrm{D}-01$ & $2.89200-01$ & $1.1376 D-33$ & $1.08470+01$ & $2.8832 \mathrm{D}-05$ & $5.2318 D-07$ & $5.42600-07$ & $5.31375+01$ \\
\hline $76 C$ & $1.2860 \mathrm{D}+02$ & $3.005 C D-01$ & $2.8952 \mathrm{D}-01$ & $4.0257 D-33$ & $1.0844 D+01$ & $2.8994 \mathrm{D}-05$ & $5.23810-07$ & $5.4368 D-07$ & $5.33290+C 1$ \\
\hline 770 & 1. $3161 D+C 2$ & $3.0106 D-01$ & $2.89830-01$ & $1.3786 \mathrm{D}-32$ & $1.0840 D+01$ & $2.91550-05$ & $5.2444 \mathrm{D}-07$ & $5.44760-07$ & $5.35190+01$ \\
\hline 780 & $1.3462 D+02$ & $3.01610-01$ & $2.90130-01$ & $4.5741 \mathrm{D}-32$ & $1.08370+01$ & $2.9317 \mathrm{D}-05$ & $5.2507 D-07$ & $5.4585 D-07$ & $5.37090+01$ \\
\hline 790 & $1.3764 D+02$ & $3.0215 \mathrm{D}-01$ & $2.9041 \mathrm{D}-01$ & $1.4723 D-31$ & $1.08340+01$ & $2.9479 D-05$ & $5.2570 D-07$ & $5.46950-07$ & $5.3897 \mathrm{D}+01$ \\
\hline 800 & $1.4066 \mathrm{D}+02$ & $3.0268 D-01$ & $2.90690-01$ & $4.60260-31$ & $1.08310+01$ & $2.9641 \mathrm{D}-05$ & $5.26330-07$ & $5.4805 D-07$ & $5.40930+01$ \\
\hline
\end{tabular}


THEEMODYNAMIC PROPERTIES OF SOLID URANIOM DIOXIDE

\begin{tabular}{|c|c|c|c|c|c|c|c|c|c|}
\hline $\begin{array}{c}T \\
(K)\end{array}$ & $\begin{array}{c}H-H(298) \\
(J / G)\end{array}$ & $\begin{array}{c}C P \\
(J / G-K)\end{array}$ & $\begin{array}{c}C V \\
(J / G-K)\end{array}$ & $\begin{array}{c}P \\
\text { (AT'M) }\end{array}$ & $\begin{array}{c}\mathrm{RHO} \\
(\mathrm{G} / \mathrm{CC})\end{array}$ & $\begin{array}{c}\text { ALPHAP } \\
(1 / K)\end{array}$ & $\begin{array}{c}\text { BETAS } \\
\text { (1/ATH) }\end{array}$ & $\begin{array}{c}\text { BETAT } \\
(1 / A T M)\end{array}$ & $\begin{array}{l}\text { GAMMAV } \\
(\operatorname{ATA} / K)\end{array}$ \\
\hline 810 & $1.4 .369 D+02$ & $3.0321 \mathrm{D}-01$ & $2.9095 \mathrm{D}-01$ & $1.3989 D-30$ & $1.08280+01$ & $2.98030-05$ & $5.2696 \mathrm{D}-07$ & $5.4917 \mathrm{D}-07$ & $5.42690+01$ \\
\hline $82 \mathrm{C}$ & $1.4673 E+02$ & $3.0372 \mathrm{D}-01$ & $2.9120 \mathrm{D}-01$ & $4.1379 \mathrm{D}-30$ & $1.08240+01$ & $2.9965 \mathrm{D}-05$ & $5.27600-07$ & $5.5029 \mathrm{D}-07$ & $5.44530+01$ \\
\hline 830 & $1.4977 D+02$ & $3.04230-01$ & $2.91430-01$ & $1.1924 \mathrm{D}-29$ & $1.08210+01$ & $3.01280-05$ & $5.2824 D-07$ & $5.5142 D-07$ & $5.4636 D+01$ \\
\hline 840 & $1.5<810+02$ & $3.04730-01$ & $2.9166 D-01$ & $3.3508 \mathrm{D}-29$ & $1.0818 D+01$ & $3.02900-05$ & $5.28870-07$ & $5.5256 \mathrm{D}-07$ & $5.48170+01$ \\
\hline 850 & $1.5586 \mathrm{D}+02$ & $3.0522 \mathrm{D}-01$ & $2.9188 \mathrm{D}-01$ & $9.1895 \mathrm{D}-29$ & $1.0815 D+01$ & $3.04530-05$ & $5.29510-07$ & $5.53710-07$ & $5.4998 D+01$ \\
\hline 860 & $1.58910+02$ & $3.05700-01$ & $2.92090-01$ & $2.4618 D-28$ & $1.08110+01$ & $3.06160-05$ & $5.3016 D-07$ & $5.5487 D-07$ & $5.51770+01$ \\
\hline 870 & $1.61970+02$ & $3.0618 \mathrm{D}-01$ & $2.92280-01$ & $6.44730-28$ & $1.08080+01$ & $3.0779 D-05$ & $5.30800-07$ & $5.56040-07$ & $5.5354 D+01$ \\
\hline 880 & $1.6504 D+02$ & $3.0665 \mathrm{D}-01$ & $2.9247 D-01$ & $1.6520 \mathrm{D}-27$ & $1.0805 D+01$ & $3.0942 D-05$ & $5.3144 \mathrm{D}-07$ & $5.57210-07$ & $5.5530 D+01$ \\
\hline 890 & $1.68110+02$ & $3.07120-01$ & $2.92650-01$ & $4.1442 \mathrm{D}-27$ & $1.08010+01$ & $3.1105 \mathrm{D}-05$ & $5.3209 D-07$ & $5.58390-07$ & $5.5705 D+C$ \\
\hline 900 & $1.7118 D+02$ & $3.0758 \mathrm{D}-01$ & $2.92820-01$ & $1.0186 D-26$ & $1.0798 D+01$ & $3.12690-05$ & $5.3274 D-07$ & $5.59580-07$ & $5.58790+01$ \\
\hline 910 & $1.74260+02$ & $3.0803 \mathrm{D}-01$ & $2.9298 \mathrm{D}-01$ & $2.4546 D-26$ & $1.0794 \mathrm{D}+01$ & $3.1433 D-05$ & $5.3339 D-07$ & $5.6079 D-07$ & $5.60510+01$ \\
\hline 920 & $1.7734 D+02$ & $3.0848 \mathrm{D}-01$ & $2.93130-01$ & $5.8030 D-26$ & $1.07910+01$ & $3.1596 \mathrm{D}-05$ & $5.3404 D-07$ & $5.61990-07$ & $5.6222 \mathrm{D}+01$ \\
\hline 930 & $1.80430+02$ & $3.0892 \mathrm{D}-01$ & $2.93280-01$ & $1.3468 D-25$ & $1.0788 D+01$ & $3.17600-05$ & $5.3469 D-07$ & $5.63210-07$ & $5.6392 D+01$ \\
\hline 940 & 1. $8352 D+02$ & $3.0936 \mathrm{D}-01$ & $2.9341 \mathrm{D}-01$ & $3.07010-25$ & $1.07840+01$ & 3. $1925 \mathrm{D}-05$ & $5.3534 \mathrm{D}-07$ & $5.6444 \mathrm{D}-07$ & 5. $65600+01$ \\
\hline 950 & $1.8662 \mathrm{~L}+02$ & $3.0979 \mathrm{D}-01$ & $2.93540-01$ & $6.87820-25$ & $1.07810+01$ & $3.20890-05$ & $5.36000-07$ & $5.6568 D-07$ & $5.6726 D+01$ \\
\hline 960 & $1.8 \subseteq 72 D+02$ & $3.1022 \mathrm{D}-01$ & $2.9366 \mathrm{D}-01$ & $1.5153 \mathrm{D}-24$ & $1.0777 D+01$ & $3.2253 D-05$ & $5.3666 D-07$ & $5.6692 \mathrm{D}-07$ & $5.6892 \mathrm{D}+01$ \\
\hline 970 & $1.9282 D+C 2$ & $3.1065 \mathrm{D}-01$ & $2.9378 \mathrm{D}-01$ & $3.2844 \mathrm{D}-24$ & $1.07740+01$ & $3.24180-05$ & $5.3732 \mathrm{D}-07$ & $5.6818 D-07$ & $5.7056 \mathrm{D}+01$ \\
\hline 980 & $1.95930+02$ & $3.11070-01$ & $2.9388 D-01$ & $7.0073 D-24$ & $1.0770 \mathrm{D}+01$ & $3.2593 \mathrm{D}-05$ & $5.37980-07$ & $5.6944 \mathrm{D}-07$ & $5.72190+01$ \\
\hline 990 & $1.9904 D+02$ & $3.1149 D-01$ & $2.9398 \mathrm{D}-01$ & $1.4723 D-23$ & $1.0767 D+01$ & $3.27480-05$ & $5.38640-07$ & $5.70710-07$ & $5.7380 D+01$ \\
\hline 1000 & $2.62160+02$ & $3.11900-01$ & $2.9407 \mathrm{D}-01$ & $3.04790-23$ & $1.0763 \mathrm{D}+01$ & $3.29130-05$ & $5.3930 D-07$ & $5.72000-07$ & $5.75400+09$ \\
\hline 1010 & $2.05280+02$ & $3.12310-01$ & $2.9416 D-01$ & $6.2193 D-23$ & $1.07600+01$ & $3.3078 \mathrm{D}-05$ & $5.3997 D-07$ & $5.73290-07$ & $5.76980+01$ \\
\hline 1020 & $2.08400+0.2$ & $3.1272 D-01$ & $2.94240-01$ & $1.2514 \mathrm{D}-22$ & $1.0756 \mathrm{D}+01$ & $3.3243 \mathrm{D}-05$ & $5.4063 \mathrm{D}-07$ & $5.7459 \mathrm{D}-07$ & $5.7855 D+01$ \\
\hline 1030 & $2.11530+02$ & $3.1312 D-C 1$ & $2.94310-C 1$ & $2.4842 \mathrm{D}-22$ & $1.0752 D+01$ & $3.31090-05$ & $5.41300-07$ & $5.75900-07$ & $5.80110+C 1$ \\
\hline 1040 & $2.14670+02$ & $3.1352 \mathrm{D}-01$ & $2.9437 D-01$ & $4.8667 D-22$ & $1.07490+01$ & $3.35740-05$ & $5.4197 D-07$ & $5.77220-07$ & $5.81650+01$ \\
\hline 50 & $2.17800+02$ & $3.1391 \mathrm{D}-01$ & $2.94430-01$ & $-9.41270-22$ & $1.0745 D+01$ & $3.3740 \mathrm{D}-05$ & $5.4265 D-07$ & $5.78550-07$ & $5.8318 D+01$ \\
\hline 1060 & $2.20940+02$ & $3.14310-01$ & $2.9449 D-01$ & $1.79800-21$ & $1.0742 D+01$ & $3.3906 D-05$ & $5.43320-07$ & $5.7989 D-07$ & $5.8469 D+01$ \\
\hline
\end{tabular}


THFRMODYHAMIC PBOPEFTIES OF SOLID ORANIUM DIOXIDR

\begin{tabular}{|c|c|c|c|c|c|c|c|c|c|}
\hline$\stackrel{T}{(R)}$ & $\begin{array}{c}H-B(298) \\
(J / G)\end{array}$ & $\begin{array}{c}C P \\
(J / G-K)\end{array}$ & $\begin{array}{c}C V \\
(J / G-K)\end{array}$ & $\begin{array}{c}P \\
(A T H)\end{array}$ & $\begin{array}{c}\text { F HO } \\
(\mathrm{G} / \mathrm{CC})\end{array}$ & $\begin{array}{c}\text { ALPHAP } \\
(1 / K)\end{array}$ & $\begin{array}{l}\text { BETAS } \\
(1 / \text { ATM })\end{array}$ & $\begin{array}{c}\text { BETAT } \\
\text { (1/ATY) }\end{array}$ & $\begin{array}{l}\text { GAMMAV } \\
(\text { ATM/K) }\end{array}$ \\
\hline 1070 & $2.2409 D+02$ & $3.1470 \mathrm{D}-01$ & $2.9453 \mathrm{D}-01$ & $3.39330-21$ & $1.0738 D+01$ & $3.40720-05$ & $5.44000-07$ & $5.8124 \mathrm{D}-07$ & $5.86190+01$ \\
\hline $108 C$ & $2.27240+02$ & $3.1509 \mathrm{D}-01$ & $2.9457 D-01$ & $6.3290 D-21$ & $1.0734 D+01$ & $3.4238 \mathrm{D}-0.5$ & $5.4467 \mathrm{D}-07$ & $5.82600-07$ & $5.8768 D+01$ \\
\hline 1090 & $2.30390+02$ & $3.1547 D-01$ & $2.94610-01$ & $1.1670 \mathrm{D}-20$ & $1.07310+01$ & $3.44050-05$ & $5.4535 \mathrm{D}-07$ & $5.8397 \mathrm{D}-07$ & $5.89150+01$ \\
\hline 1160 & $2.3355 D+02$ & $3.1585 D-01$ & $2.94640-01$ & $2.1281 \mathrm{D}-20$ & $1.07270+01$ & $3.4571 \mathrm{D}-05$ & $5.46030-07$ & $5.8535 \mathrm{D}-07$ & $5.90610+01$ \\
\hline 1110 & $2.3671 D+02$ & $3.1623 \mathrm{~L}-01$ & $2.9466 \mathrm{D}-01$ & $3.8390 \mathrm{D}-20$ & $1.0723 \mathrm{D}+01$ & 3. 473 म $D-05$ & $5.4671 D-07$ & $5.86740-07$ & $5.92050+01$ \\
\hline $112 \mathrm{C}$ & $2.3987 D+02$ & $3.16610-C 1$ & $2.94680-01$ & $6.8526 \mathrm{D}-20$ & $1.0719 D+01$ & $3.4925 D-05$ & $5.4740 \mathrm{D}-07$ & $5.8814 \mathrm{D}-07$ & $5.93480+01$ \\
\hline 1130 & $2.43040+02$ & $3.1699 \mathrm{D}-01$ & $2.9469 D-01$ & $1.2107 D-19$ & $1.07160+01$ & $3.50710-05$ & $5.480 \forall D-07$ & $5.8954 D-07$ & $5.94890+01$ \\
\hline 1140 & $2.46210+02$ & $3.1736 \mathrm{D}-01$ & $2.94700-01$ & $2.1178 D-19$ & $1.0712 \mathrm{D}+01$ & $3.5239 \mathrm{D}-\mathrm{C} 5$ & $5.4877 D-07$ & $5.90960-07$ & $5.9629 D+01$ \\
\hline 1150 & $2.49390+02$ & $3.1773 \mathrm{D}-01$ & $2.9470 D-01$ & $3.6688 D-19$ & $1.07 C 8 D+01$ & $3.5406 \mathrm{D}-05$ & $5.4946 \mathrm{D}-07$ & $5.9239 D-07$ & $5.9767 D+01$ \\
\hline 1160 & $2.5257 D+02$ & $3.1810 \mathrm{D}-\mathrm{C} 1$ & $2.9470 \mathrm{D}-01$ & $6.2956 \mathrm{D}-19$ & $1.07040+01$ & 3. $5573 \mathrm{D}-05$ & $5.5015 D-07$ & $5.93830-07$ & $5.99040+01$ \\
\hline 1170 & $2.5575 \mathrm{D}+02$ & $3.1847 \mathrm{D}-01$ & $2.9469 D-01$ & $1.07040-18$ & $1.0700 \mathrm{D}+01$ & $3.57410-05$ & $5.50840-07$ & $5.9528 \mathrm{D}-07$ & $6.00400+01$ \\
\hline 1180 & $2.5894 \mathrm{D}+02$ & $3.1883 D-01$ & $2.9468 D-C 1$ & $1.8036 \mathrm{D}-18$ & $1.0697 D+01$ & $3.5909 D-05$ & $5.5154 \mathrm{D}-07$ & $5.9674 \mathrm{D}-37$ & $6.0174 \mathrm{D}+01$ \\
\hline 1190 & $2.62130+02$ & $3.1920 \mathrm{D}-01$ & $2.94660-01$ & $3.0125 D-18$ & $1.0693 D+31$ & $3.6076 \mathrm{D}-05$ & $5.52230-07$ & $5.98210-07$ & $6.03070+01$ \\
\hline 1200 & $2.6532 D+02$ & $3.1956 \mathrm{D}-01$ & $2.9464 \mathrm{D}-01$ & $4.9888 D-18$ & $1.0689 D+01$ & $3.6244 \mathrm{D}-05$ & $5.5293 \mathrm{D}-07$ & $5.9969 D-07$ & $6.04380+01$ \\
\hline 1210 & $2.6852 \mathrm{D}+02$ & $3.1992 D-01$ & $2.9462 \mathrm{D}-01$ & 8. $1932 \mathrm{D}-18$ & $1.0685 D+01$ & $3.64120-05$ & $5.5363 D-07$ & $6.01180-07$ & $6.05680+01$ \\
\hline 1220 & $2.7172 D+02$ & $3.2028 D-01$ & $2.9459 \mathrm{D}-01$ & $1.3347 \mathrm{D}-17$ & $1.06810+01$ & $3.6580 \mathrm{D}-05$ & $5.54330-07$ & $6.0268 \mathrm{D}-07$ & $6.0696 \mathrm{D}+01$ \\
\hline 1230 & $2.7+92 D+02$ & $3.2064 \mathrm{D}-01$ & $2.9455 \mathrm{D}-01$ & 2. $15700-17$ & $1.06770+01$ & $3.67490-05$ & $5.55030-07$ & $6.0420 \mathrm{D}-07$ & $6.0823 D+01$ \\
\hline 1240 & $2.7813 D+02$ & $3.2100 \mathrm{D}-01$ & $2.94510-01$ & $3.4591 \mathrm{D}-17$ & $1.0673 D+01$ & $3.69170-05$ & $5.5574 \mathrm{D}-07$. & $6.0572 D-07$ & $6.0948 D+01$ \\
\hline 1250 & $2.8134 \mathrm{D}+02$ & $3.2135 \mathrm{D}-01$ & $2.9447 \mathrm{D}-01$ & $5.50550-17$ & $1.06690+01$ & $3.7086 \mathrm{D}-05$ & $5.5645 \mathrm{D}-07$ & $6.0725 \mathrm{D}-07$ & $6.1072 D+01$ \\
\hline 1260 & $2.8456 \mathrm{D}+02$ & $3.21710-01$ & $2.94112 \mathrm{D}-01$ & $8.6982 D-17$ & $1.06650+01$ & $3.7255 \mathrm{D}-05$ & $5.5715 D-07$ & $6.08800-07$ & $6.11940+01$ \\
\hline $127 \mathrm{C}$ & $2.8778 D+02$ & $3.2207 D-01$ & $2.9437 D-01$ & $1.3644 D-16$ & $1.06610+01$ & $3.74240-95$ & $5.5786 \mathrm{D}-07$ & $6.1035 D-07$ & $6.13150+01$ \\
\hline 1280 & $2.9100 \mathrm{D}+02$ & $\Xi .22420-01$ & $2.9431 \mathrm{D}-01$ & 2. $1251 \mathrm{D}-16$ & $1.0657 \mathrm{D}+01$ & $3.7593 \mathrm{D}-05$ & $5.5858 \mathrm{D}-07$ & $6.1192 \mathrm{D}-07$ & $6.1434 \mathrm{D}+01$ \\
\hline 1290 & $2.9423 D+02$ & $3.2277 D-01$ & $2.94250-01$ & $3.2873 D-16$ & $1.0653 \mathrm{D}+01$ & $3.7762 \mathrm{D}-05$ & $5.5929 D-07$ & $6.1349 \mathrm{D}-07$ & $6.15520+01$ \\
\hline 1300 & $2.9746 \mathrm{E}+02$ & $3.2313 D-01$ & $2.9419 \mathrm{D}-01$ & $5.05110-16$ & $1.0649 D+01$ & $3.7931 \mathrm{D}-05$ & $5.6001 D-07$ & $6.1508 D-07$ & $E .166^{\circ} D+01$ \\
\hline 1310 & $3.00690+C 2$ & $3.2348 \mathrm{D}-01$ & $2.9413 n-61$ & $7.7105 D-16$ & $1.0645 D+01$ & $3.8101 \mathrm{D}-05$ & $5.6072 \mathrm{D}-07$ & $6.1668 D-07$ & $6.1784 D+01$ \\
\hline 1320 & $3.0393 D+02$ & $3.2383 D-01$ & $2.9406 \mathrm{D}-01$ & $1.1695 D-15$ & $1.06410+01$ & $3.8270 D-05$ & $5.6144 D-07$ & $6.1829 \mathrm{D}-07$ & $6.1897 D+01$ \\
\hline
\end{tabular}


THFRMODYNAMIC PROPEETIES OF SOLID URANIUH DIOXIDB

\begin{tabular}{|c|c|c|c|c|c|c|c|c|}
\hline $\begin{array}{c}H-H(298) \\
(J / G)\end{array}$ & $\begin{array}{c}C F \\
(J / G-K)\end{array}$ & $\begin{array}{c}C V \\
(J / G-K)\end{array}$ & $\stackrel{\mathrm{P}}{(\operatorname{AT} M)}$ & $\begin{array}{l}\text { RHO } \\
(\mathrm{G} / \mathrm{CC})\end{array}$ & $\begin{array}{c}\text { ALPGAP } \\
(1 / K)\end{array}$ & $\begin{array}{c}\text { ВETAS } \\
(1 / \text { ATH })\end{array}$ & $\begin{array}{l}\text { BETAT } \\
(1 / \text { ATA })\end{array}$ & $\begin{array}{l}\text { GAMHAV } \\
(A T H / K)\end{array}$ \\
\hline $3.0717 \mathrm{D}+02$ & $3.2419 \mathrm{D}-01$ & $2.93990-01$ & $1.7628 \mathrm{D}-15$ & $1.06370+01$ & $3.844 \cup D-05$ & $5.6216 \mathrm{D}-07$ & $6.1991 D-07$ & $6.20090+01$ \\
\hline $3.1041 D+02$ & $3.2454 D-01$ & $2.9391 \mathrm{D}-01$ & $2.6408 \mathrm{D}-15$ & $1.0633 D+01$ & $3.8610 D-05$ & $5.62890-07$ & $6.2154 D-07$ & $6.21200+01$ \\
\hline $3.1366 \mathrm{D}+02$ & $3.2489 D-01$ & $2.9383 D-01$ & $3.9325 D-15$ & $1.06290+01$ & $3.87800-05$ & $5.6361 \mathrm{D}-07$ & $6.23190-07$ & $6.2229 D+01$ \\
\hline 3. $1691 D+02$ & $3.2525 \mathrm{D}-\mathrm{C} 1$ & $2.93750-01$ & $5.8218 D-15$ & $1.0624 D+01$ & $3.8950 D-05$ & $5.6434 D-07$ & $6.2484 D-07$ & $6.2337 \mathrm{D}+01$ \\
\hline $3.2016 D+02$ & $3.256 C D-01$ & $2.9367 \mathrm{D}-01$ & $8.5697 \mathrm{D}-15$ & $1.0620 D+C 1$ & $3.91210-05$ & $5.65070-07$ & $6.26500-07$ & $6.2443 D+01$ \\
\hline $3.2342 D+02$ & $3.2596 \mathrm{D}-01$ & $2.9359 \mathrm{D}-01$ & $1.2544 D-14$ & $1.0016 \mathrm{D}+01$ & $3.92910-05$ & $5.65800-07$ & $6.2818 D-07$ & $6.2548 D+01$ \\
\hline 3. $2668 \mathrm{D}+02$ & $3.26310-01$ & $2.93500-C 1$ & $1.82610-14$ & $1.0612 D+01$ & $3.9462 \mathrm{D}-05$ & $5.66530-07$ & $6.2987 D-07$ & $6.2651 D+01$ \\
\hline $3.2994 D+02$ & $3.2667 \mathrm{D}-01$ & $2.93+10-01$ & $2.64410-14$ & $1.0608 D+01$ & $3.96320-05$ & $5.6726 \mathrm{D}-07$ & $6.31560-07$ & $6.27530+01$ \\
\hline $3.33210+02$ & $3.27030-01$ & $2.9332 \mathrm{D}-\mathrm{C} ?$ & $3.80860-14$ & $1.0604 \mathrm{D}+01$ & $3.98030-05$ & $5.6800 \mathrm{D}-07$ & $6.3327 D-07$ & $6.28530+C 1$ \\
\hline $3.3649 D+02$ & $3.27390-01$ & $2: 93230-01$ & $5.4578 D-14$ & $1.05990+01$ & $3.9974 D-05$ & $5.6874 D-07$ & $6.35000-07$ & $6.2952 D+01$ \\
\hline $3.3976 D+C 2$ & $3.2775 \mathrm{D}-01$ & $2.9313 D-01$ & $7.7817 \mathrm{D}-14$ & $1.05950+01$ & $4.0145 \mathrm{D}-.05$ & $5.69480-07$ & $6.3673 D-07$ & $6.305 C D+01$ \\
\hline $3.4304 D+02$ & $3.2811 \mathrm{D}-01$ & $2.9304 D-01$ & 1. $1041 D-13$ & $1.05910+01$ & $4.03170-05$ & $5.70220-07$ & $6.3847 D-07$ & $6.31460+01$ \\
\hline $3.46320+02$ & $3.2848 \mathrm{D}-01$ & $2.9295 \mathrm{D}-\mathrm{C} 1$ & $1.5589 D-13$ & $1.0586 \mathrm{D}+01$ & $4.04880-05$ & $5.7096 \mathrm{D}-07$ & $6.4022 \mathrm{D}-07$ & $6.3240 \mathrm{D}+01$ \\
\hline $3.4961 D+02$ & $3.2885 \mathrm{D}-01$ & $2.92850-01$ & $2.1908 \mathrm{D}-13$ & $1.0582 \mathrm{D}+01$ & $4.06600-05$ & $5.71710-07$ & $6.41990-07$ & $6.3334 D+01$ \\
\hline $3.52900+02$ & $3.2922 \mathrm{D}-01$ & $2.9275 \mathrm{D}-01$ & $3.0646 D-13$ & $1.05780+01$ & $4.08310-05$ & $5.7246 \mathrm{D}-07$ & $6.43770-07$ & $6.3426 D+01$ \\
\hline $3.56190+02$ & $3.29600-0.9$ & $2.9266 \mathrm{D}-01$ & $4.26740-13$ & $1.0573 D+01$ & $4.10030-05$ & $5.73210-07$ & $6.4555 \mathrm{D}-07$ & $6.3516 \mathrm{D}+01$ \\
\hline $3.59490+02$ & $3.2997 \mathrm{D}-01$ & $2.9256 D-01$ & $5.9160 D-13$ & $1.0569 D+01$ & $4.1175 D-05$ & $5.7396 \mathrm{D}-07$ & $6.4735 \mathrm{D}-07$ & $6.3605 D+01$ \\
\hline $3.6279 D+02$ & $3.3036 \mathrm{D}-01$ & $2.9247 D-01$ & 8. $16580-13$ & $1.0565 \mathrm{D}+01$ & $4.1347 D-05$ & $5.74710-07$ & $6.4916 \mathrm{D}-07$ & $6.3693 \mathrm{D}+01$ \\
\hline $3.6510 \mathrm{D}+02$ & $3.30740-01$ & $2.9238 D-01$ & $1.1223 \mathrm{D}-12$ & $1.05600+01$ & $4.1519 \mathrm{D}-05$ & $5.75470-07$ & $6.5098 \mathrm{D}-07$ & $6.3779 D+01$ \\
\hline $3.6 \subseteq 41 D+02$ & $3.3113 \mathrm{D}-\mathrm{C} 1$ & $2.32280-01$ & $1.5361 \mathrm{D}-12$ & $1.0556 \mathrm{D}+01$ & $4.16910-05$ & $5.7623 \mathrm{D}-07$ & $6.5281 \mathrm{D}-07$ & E. $3864 \mathrm{~N}+01$ \\
\hline $3.72720+02$ & $3.3153 D-01$ & $2.9219 \mathrm{D}-01$ & $2.0938 D-12$ & $1.05520+01$ & $4.1864 D-05$ & $5.7699 D-07$ & $6.5466 \mathrm{D}-07$ & $6.3948 D+01$ \\
\hline $3.7 \epsilon 04 D+02$ & $3.3193 D-C 1$ & $2.92110-01$ & $2.8426 \mathrm{D}-12$ & $1.05470+01$ & $4.2037 \mathrm{D}-05$ & $5.7775 D-07$ & $6.5651 \mathrm{D}-07$ & $6.4030 \mathrm{D}+01$ \\
\hline $3.7936 \mathrm{D}+02$ & $3.32330-01$ & $2.9202 \mathrm{D}-01$ & $3.84390-12$ & $1.0543 \mathrm{D}+01$ & $4.22090-05$ & $5.7851 D-n 7$ & $6.5837 D-07$ & $6.41110+01$ \\
\hline $3.8269 D+02$ & $3.32740-01$ & $2.91940-01$ & $5.17790-12$ & $1.05390+01$ & $4.23820-05$ & $5.7928 D-07$ & $6.60250-07$ & $6.41910+01$ \\
\hline $3.8602 D+02$ & $3.3316 \mathrm{D}-01$ & $2.9186 D-01$ & $6.9484 D-12$ & $1.0534 D+01$ & $4.2555 \mathrm{D}-05$ & $5.8005 D-07$ & $6.62130-07$ & $6.42690+01$ \\
\hline $3.8935 D+02$ & $3.3359 D-01$ & $2.91780-01$ & $9.2897 D-12$ & $1.0529 D+U 1$ & $4.27280-05$ & $5.8082 D-07$ & $6.61030-07$ & $6.43470+01$ \\
\hline
\end{tabular}


THERMODYNAMIC PROPEETIES OF SOLID URARIDM DIOXIDB

\begin{tabular}{|c|c|c|c|c|c|c|c|c|c|}
\hline $\begin{array}{l}T \\
(K)\end{array}$ & $\begin{array}{c}H-H(25 \theta) \\
(J / G)\end{array}$ & $\begin{array}{c}C P \\
(J / G-K)\end{array}$ & $\begin{array}{c}C V \\
(J / G-K)\end{array}$ & $\stackrel{P}{\text { (ATM) }}$ & $\begin{array}{c}I B O \\
(G / C C)\end{array}$ & $\begin{array}{l}\text { A LPHAF } \\
(1 / x)\end{array}$ & $\begin{array}{l}\text { BETAS } \\
(1 / \text { AT })\end{array}$ & $\begin{array}{l}\text { BPTAT } \\
(1 / A T A)\end{array}$ & $\begin{array}{l}\text { GAMMAV } \\
\text { ( ATA/R) }\end{array}$ \\
\hline 1590 & $3.9269 \mathrm{D}+02$ & $3.3402 \mathrm{D}-01$ & $2.9171 \mathrm{D}-01$ & $1.2375 D-11$ & $1.0525 \mathrm{D}+01$ & $4.29010-05$ & $5.8159 D-07$ & $6.6594 \mathrm{D}-07$ & $6.414230+01$ \\
\hline $160 \mathrm{C}$ & $3.9603 D+02$ & $3.3445 \mathrm{D}-01$ & $2.9164 \mathrm{D}-01$ & $1.6425 \mathrm{D}-11$ & $1.05200+01$ & 4. $30750-05$ & $5.8236 D-G 7$ & $6.67850-07$ & $6.44970+01$ \\
\hline 1610 & $3.9 c 38 D+02$ & $3.3490 D-01$ & & $2.1724 \mathrm{D}-11$ & $1.05160+01$ & $4.3248 \mathrm{D}-05$ & & & \\
\hline 1620 & $4.02730+02$ & $3.3536 \mathrm{D}-01$ & & $2.8634 \mathrm{D}-11$ & $1.05110+01$ & 4. $3422 \mathrm{D}-05$ & & & \\
\hline 1630 & $4.060 A D+02$ & $3.3582 \mathrm{D}-01$ & & $3.76150-11$ & $1.0506 \mathrm{D}+01$ & $4.35950-05$ & & & \\
\hline $164 C$ & $4.0 \$ 44 D+02$ & $3.3629 D-01$ & & $4.9248 D-11$ & $1.0502 D+01$ & 4. $37690-05$ & & & \\
\hline 1650 & $4.12810+02$ & $3.3678 \mathrm{D}-01$ & & $6.4269 \mathrm{D}-11$ & $1.04970+01$ & $4.39430-05$ & & & \\
\hline 1660 & $4.1618 D+02$ & $3.3727 \mathrm{D}-01$ & & $8.3602 \mathrm{D}-11$ & $1.04930+01$ & $4.41170-05$ & & & \\
\hline 1670 & 4. $19550+02$ & $3.3777 \mathrm{D}-01$ & & $1.08410-10$ & $1.04890+j 1$ & $4.4292 \mathrm{D}-05$ & & & \\
\hline $168 \mathrm{C}$ & $4.2294 \mathrm{D}+02$ & $3.38290-01$ & & $1.40140-10$ & $1.04830+01$ & $4.44660-05$ & & & \\
\hline 1690 & $4.2632 D+02$ & $3.3882 \mathrm{D}-01$ & & $1.8062 \mathrm{D}-10$ & $1.04790+01$ & $4.4640 \mathrm{D}-05$ & & & \\
\hline 1700 & $4.29710+02$ & $3.3936 \mathrm{D}-01$ & & $2.3208 D-10$ & $1.04740+01$ & $4.48150-05$ & & & \\
\hline 1710 & $4.33110+02$ & $3.3992 \mathrm{D}-01$ & & $2.97350-10$ & $1.0469 \mathrm{D}+01$ & $4.45900 \mathrm{D}-05$ & & & \\
\hline 1720 & $4.36510+02$ & $3.4048 D-01$ & & $3.7986 \mathrm{D}-10$ & $1.04640+01$ & $4.51640-05$ & & & \\
\hline 1730 & $4.3992 \mathrm{D}+02$ & $3.4107 \mathrm{D}-01$ & & $4.83910-10$ & $1.04600+01$ & $4.53390-05$ & & & \\
\hline $174 C$ & $4.4 .333 \mathrm{D}+02$ & $3.4167 D-01$ & & $6.1474 \mathrm{D}-10$ & $1.04550+01$ & $4.55140-05$ & & & \\
\hline 1750 & $4.46750+02$ & $3.4228 \mathrm{D}-01$ & & $7.78800-10$ & $1.0450 D+C 1$ & $4.5690 D-05$ & & & \\
\hline 1760 & $4.5018 D+C 2$ & $3.4292 \mathrm{D}-01$ & & $9.84010-10$ & $1.0445 \mathrm{D}+01$ & $4.5865 \mathrm{D}-05$ & & & \\
\hline 1770 & $4.5361 D+02$ & $3.4357 \mathrm{D}-01$ & & $1.24000-09$ & $1.04410+01$ & $4.60400-05$ & & & \\
\hline 1780 & $4.5705 D+02$ & $3.4424 D-01$ & & $1.5585 \mathrm{D}-\mathrm{C9}$ & $1.0436 \mathrm{D}+01$ & $4.6216 \mathrm{D}-05$ & & & \\
\hline 1790 & $4.6 C 49 D+C 2$ & $3.4492 \mathrm{D}-\mathrm{C1}$ & & $1.9539 D-09$ & $1.0431 \mathrm{D}+01$ & $4.6392 D-05$ & & & \\
\hline 1800 & $4.6395 D+02$ & $3.4563 D-01$ & & $2.44340-09$ & $1.04260+01$ & $4.6567 \mathrm{D}-05$ & & & \\
\hline 1810 & $4.67410+02$ & $3.46360-01$ & & $3.0481 \mathrm{D}-09$ & $1.04210+01$ & $4.57430-05$ & & & \\
\hline 1820 & $4.7087 D+C 2$ & $3.47110-01$ & & $3.7931 \mathrm{D}-09$ & $1.0416 \mathrm{D}+01$ & $4.69190-05$ & & & \\
\hline 1830 & $4.7435 D+02$ & $3.47890-01$ & & $4.70890-09$ & $1.04110+01$ & $4.7096 D-05$ & & & \\
\hline 1840 & $4.77830+02$ & $3.4868 \mathrm{D}-01$ & & $5.8321 \mathrm{D}-09$ & $1.04060+01$ & $4.72720-05$ & & & \\
\hline
\end{tabular}


THEFHODYNAMIC PROPERTIES OP SOLID URANIUG DIOXIUE

\begin{tabular}{|c|c|c|c|c|c|c|}
\hline$\stackrel{T}{(K)}$ & $\begin{array}{c}\mathrm{H}-\mathrm{H}(298) \\
(J / G)\end{array}$ & $\begin{array}{c}C P \\
(J / G-K)\end{array}$ & $\begin{array}{c}C V \\
(J / G-K)\end{array}$ & $\stackrel{P}{(A T E)}$ & $\begin{array}{l}\text { Fно } \\
\text { (G/CC) }\end{array}$ & $\begin{array}{c}A L P H A P \\
(1 / K)\end{array}$ \\
\hline 1850 & $4.81320+02$ & $3.4950 \mathrm{D}-01$ & & $7.2066 \mathrm{D}-09$ & $1.04010+01$ & $4.74480-05$ \\
\hline 1860 & $4.8482 D+02$ & $3.5035 \mathrm{D}-01$ & & $8.8847 \mathrm{D}-09$ & $1.03970+01$ & $4.76250-0.5$ \\
\hline 1870 & $4.8833 D+02$ & $3.5122 \mathrm{D}-01$ & & $1.09290-08$ & $1.0392 D+01$ & $4.7801 D-05$ \\
\hline 1880 & 4. $91850+02$ & $3.5212 \mathrm{D}-01$ & & $1.3414 \mathrm{D}-08$ & $1.0387 \mathrm{D}+\mathrm{C1}$ & $4.7978 D-05$ \\
\hline 1890 & $4.9537 D+02$ & $3.53 C 5 D-01$ & & $1.6429 D-08$ & $1.03820+01$ & $4.8155 D-05$ \\
\hline 1900 & $4.98910+02$ & $3.54010-01$ & & $2 . C 079 D-08$ & $1.0377 D+01$ & $4.8332 D-05$ \\
\hline 1910 & $5.0245 D+02$ & $3.55 \mathrm{COD}-01$ & & $2.4487 D-C 8$ & $1.0372 D+01$ & $4.8509 D-05$ \\
\hline 1920 & $5.06010+02$ & $3.56020-01$ & & $2.98 C 2 D-08$ & $1.03660+01$ & $4.8686 \mathrm{D}-05$ \\
\hline 1930 & $5.0957 D+02$ & $3.5707 \mathrm{D}-01$ & & $3.6197 D-08$ & $1.0361 D+01$ & $4.88640-05$ \\
\hline 1940 & $5.1315 D+02$ & $3.5 E 15 D-01$ & & $4.3876 \mathrm{D}-\cup 8$ & $1.0356 \mathrm{D}+01$ & $4.90410-05$ \\
\hline 1550 & $5.1674 D+02$ & $3.59270-01$ & & $5.3079 \mathrm{D}-08$ & $1.0351 \mathrm{D}+01$ & $4.9218 D-05$ \\
\hline 1960 & $5.20340+02$ & $3.6043 D-01$ & & $6.4088 D-C 8$ & $1.03460+01$ & $4.9396 \mathrm{D}-05$ \\
\hline 1970 & $5.2395 D+02$ & $3.6162 \mathrm{D}-01$ & & $7.7232 \mathrm{D}-\mathrm{C} 8$ & $1.03410+31$ & $4.9574 \mathrm{D}-05$ \\
\hline 1980 & $5.27570+02$ & $3.6285 \mathrm{D}-01$ & & $9.2897 D-C 8$ & $1.03360+01$ & $4.9752 D-05$ \\
\hline 1990 & $5.3120 D+02$ & $3.6412 \mathrm{D}-01$ & & $1.11530-07$ & $1.03310+01$ & $4.9930 D-05$ \\
\hline 2000 & $5.3485 D+02$ & $3.6543 \mathrm{D}-01$ & & $1.3366 \mathrm{D}-07$ & $1.0326 \mathrm{D}+01$ & $5.01080-05$ \\
\hline 2010 & $5.3851 \mathrm{D}+02$ & $3.6678 \mathrm{D}-01$ & & $1.5989 \mathrm{D}-07$ & $1.03200+01$ & $5.0286 D-05$ \\
\hline 2026 & $5.4219 D+02$ & $3.68170-01$ & & $1.9093 \mathrm{D}-07$ & $1.0315 D+01$ & $5.04640-05$ \\
\hline 2030 & $5.4587 D+02$ & $3.69600-01$ & & $2.2759 \mathrm{D}-\mathrm{C} 7$ & $1.0310 D+01$ & $5.0643 D-05$ \\
\hline 2040 & $5.4958 D+02$ & $3.7108 D-01$ & & $2.7 C 840-07$ & $1.03050+01$ & $5.08210-05$ \\
\hline 2050 & $5.5330 D+02$ & $3.72610-01$ & & $3.21750-07$ & $1.02990+01$ & $5.1000 D-05$ \\
\hline 2060 & $5.5703 D+C 2$ & $3.7419 \mathrm{D}-01$ & & $3.8159 D-07$ & $1.0294 \mathrm{D}+01$ & $5.11790-05$ \\
\hline 2070 & $5.60780+02$ & $3.75810-01$ & & $4.5181 D-07$ & $1.02890+01$ & $5.1358 D-05$ \\
\hline 2080 & 5. $6455 \mathrm{D}+\mathrm{C2}$ & $3,7748 \mathrm{D}-\mathrm{C} 1$ & & $5.3409 D-07$ & $1.0284 D+01$ & $5.1537 D-05$ \\
\hline 2090 & $5.6833 D+02$ & $3.79210-01$ & & $6.3035 D-07$ & $1.02780+01$ & $5.17160-05$ \\
\hline 2100 & 5. $7213 D+C 2$ & $3.80980-01$ & & $7.4277 D-07$ & $1.02730+01$ & $5.1895 \mathrm{D}-05$ \\
\hline
\end{tabular}


THERMODTNAMIC PROPERTIES OF SOLID ORANIUM DIOXIDE

\begin{tabular}{|c|c|c|c|c|c|c|}
\hline $\begin{array}{c}T \\
(K)\end{array}$ & $\begin{array}{c}A-H(298) \\
(J / G)\end{array}$ & $\begin{array}{c}C P \\
(J / G-K)\end{array}$ & $\begin{array}{c}C V \\
(J / G-K)\end{array}$ & $\begin{array}{c}\mathrm{P} \\
(\mathrm{ATA})\end{array}$ & $\begin{array}{l}\text { R मо } \\
(\mathrm{G} / \mathrm{CC})\end{array}$ & $\begin{array}{c}\text { ALPHAP } \\
(1 / K)\end{array}$ \\
\hline 2110 & $5.7595 D+02$ & $3.62810-01$ & & $6.7390 D-07$ & $1.0268 D+01$ & $5.2074 \mathrm{D}-05$ \\
\hline 2120 & $5.79790+02$ & $3.847 C 0-01$ & & $1.0266 \mathrm{D}-06$ & $1.02620+01$ & $5.22530-05$ \\
\hline 2130 & $5.8364 D+02$ & $3.8664 D-01$ & & $1.2041 \mathrm{D}-06$ & $1.0257 D+01$ & $5.24330-05$ \\
\hline 2140 & $5.8752 D+02$ & $3.8865 \mathrm{D}-\mathrm{C} 1$ & & $1.41030-06$ & $1.02520+01$ & $5.26130-05$ \\
\hline 2150 & $5.9142 D+02$ & $3.9071 \mathrm{~L}-\mathrm{C1}$ & & $1.6493 D-06$ & $1.0246 \mathrm{D}+01$ & $5.27920-05$ \\
\hline 2160 & $5.9534 D+C 2$ & $3.5283 D-01$ & & $1.9260 D-06$ & $1.02410+01$ & $5.29720-05$ \\
\hline 2170 & E. $99270+02$ & $3.95010-01$ & & $2.2460 \mathrm{D}-06$ & $1.02350+21$ & $5.31520-05$ \\
\hline 2180 & $6.0324 D+02$ & $3.9726 \mathrm{D}-01$ & & $2.6154 \mathrm{D}-06$ & $1.02300+01$ & $5.33320-05$ \\
\hline 2196 & $6.07220+02$ & $3.9957 \mathrm{D}-01$ & & $3.0414 D-C 6$ & $1.02240+01$ & $5.35120-05$ \\
\hline $220 \mathrm{C}$ & $6.1123 \mathrm{D}+\mathrm{C2}$ & $4.01950-01$ & & $3.5318 \mathrm{D}-06$ & $1.02190+J 1$ & $5.36920-05$ \\
\hline 2210 & $6.1526 D+02$ & $4.0439 \mathrm{D}-01$ & & 4. C958D-06 & $1.0213 \mathrm{D}+01$ & $5.38730-05$ \\
\hline 2220 & $6.1932 D+02$ & $4.0691 D-01$ & & $4.7436 \mathrm{D}-\mathrm{C6}$ & $1.0208 D+01$ & $5.4053 D-05$ \\
\hline 2230 & $6.2340 D+02$ & $4.0950 \mathrm{D}-01$ & & $5.4866 \mathrm{D}-06$ & $1.0202 D+01$ & $5.42340-05$ \\
\hline $224 \mathrm{C}$ & $6.27510+02$ & $4.1216 D-01$ & & $6.3377 D-C 6$ & $1.0197 \mathrm{D}+01$ & $5.4414 \mathrm{D}-05$ \\
\hline 2250 & $6.31640+02$ & $4.1489 D-01$ & & $7.31140-06$ & $1.01910+01$ & $5.45950-05$ \\
\hline 2260 & $6.35800+02$ & $4.17700-01$ & & $8.42410-06$ & $1.0186 \mathrm{D}+01$ & $5.4776 D-05$ \\
\hline 2270 & E. $3999 D+C 2$ & $4.20580-01$ & & $9.6940 \mathrm{D}-06$ & $1.01800+01$ & $5.4957 \mathrm{D}-05$ \\
\hline 2280 & $6.4422 D+02$ & $4.23540-01$ & & $1.1142 \mathrm{D}-05$ & $1.01740+01$ & $5.5138 D-05$ \\
\hline 2290 & $6.4847 D+02$ & $4.26580-01$ & & $1.27900-05$ & $1.01690+01$ & $5.53190-05$ \\
\hline 2300 & $6.52750+02$ & $4.29710-01$ & & $1.4664 \mathrm{D}-05$ & $1.01630+31$ & $5.5500 D-05$ \\
\hline 2310 & $\epsilon .5706 D+C 2$ & $4.32910-01$ & & $1.6794 D-05$ & $1.01580+01$ & $5.56810-05$ \\
\hline 2320 & $6.61410+02$ & $4.36200-01$ & & $1.9210 D-05$ & $1.01520+01$ & $5.58630-05$ \\
\hline 2330 & $6.6578 D+02$ & $4.39580-01$ & & $2.19480-65$ & $1.01460+01$ & $5.60440-05$ \\
\hline 2340 & $6.70200+02$ & $4.4304 D-01$ & & $2.50480-05$ & $1.01410+01$ & $5.6226 \mathrm{D}-05$ \\
\hline 2350 & $6.74650+02$ & $4.46590-01$ & & $2.8554 D-05$ & $1.0135 D+01$ & $5.6408 D-05$ \\
\hline 2360 & $6.7513 D+02$ & $4.5024 D-01$ & & $3.25140-05$ & $1.0129 D+01$ & $5.65890-05$ \\
\hline
\end{tabular}


THEF UODYNAMIC REOPEETIES OF SOLID URANIUY DIOXIDE

\begin{tabular}{|c|c|c|c|c|c|c|}
\hline$\stackrel{T}{T}$ & $\begin{array}{c}B-8(298) \\
(J / G)\end{array}$ & $\begin{array}{c}C P \\
(J / G-R)\end{array}$ & $\begin{array}{c}C V \\
(J / G-R)\end{array}$ & $\begin{array}{c}P \\
(\mathrm{ATM})\end{array}$ & $\begin{array}{l}\text { RHO } \\
(\mathrm{G} / \mathrm{CC})\end{array}$ & $\begin{array}{c}\text { AL P HAP } \\
(1 / K)\end{array}$ \\
\hline $237 \mathrm{C}$ & $6.8365 t+02$ & $4.5397 \mathrm{D}-01$ & & $3.6983 \mathrm{D}-05$ & $1.0123 \mathrm{D}+01$ & $5.67710-05$ \\
\hline 2380 & $6.8821 D+02$ & $4.57800-01$ & & $4.2021 D-05$ & $1.01180+01$ & $5.6953 \mathrm{D}-05$ \\
\hline 2390 & $6.9281 D+02$ & $4.6172 \mathrm{D}-01$ & & $4.7694 D-05$ & $1.0112 \mathrm{D}+01$ & $5.7135 D-05$ \\
\hline 2400 & $6.9744 \mathrm{D}+02$ & $4.6574 \mathrm{D}-01$ & & $5.40750-05$ & $1.01060+01$ & $5.73180-05$ \\
\hline 2410 & $7.02120+02$ & $4.6985 \mathrm{D}-01$ & & $6.12470-05$ & $1.01000+01$ & $5.7500 D-05$ \\
\hline 2420 & $7.0684 \mathrm{D}+. \mathrm{C2}$ & $4.74070-01$ & & $6.92990-05$ & $1.0094 \mathrm{D}+01$ & $5.7682 \mathrm{D}-05$ \\
\hline 2430 & $7.1160 \mathrm{D}+02$ & $4.78390-09$ & & $7.83300-05$ & $1.0089 D+0 !$ & $5.7865 \mathrm{D}-05$ \\
\hline 2440 & $7.16410+C 2$ & $4.82800-01$ & & $8.6448 D-05$ & $1.0083 \mathrm{D}+01$ & $5.8047 \mathrm{D}-05$ \\
\hline 2450 & $7.21260+02$ & $4.87330-01$ & & $9.97750-05$ & $1.00770+31$ & $5.82300-05$ \\
\hline 2460 & $7.2616 \mathrm{D}+02$ & $4.91960-01$ & & $1.1244 D-04$ & $1.00710+01$ & $5.8413 D-05$ \\
\hline 2470 & $7.311 \dot{v} D+02$ & $4.96690-01$ & & $1.2659 D-04$ & $1.00650+01$ & $5.8595 \mathrm{D}-05$ \\
\hline 2480 & $7.3609 D+02$ & $5.0154 \mathrm{D}-01$ & & $1.42390-04$ & $1.0059 D+01$ & $5.8778 D-05$ \\
\hline 2490 & $7.4113 D+C 2$ & $5.06490-01$ & & $1.60010-04$ & $1.0053 \mathrm{D}+01$ & $5.89610-05$ \\
\hline 2500 & $7.46220+02$ & $5.1156 \mathrm{D}-01$ & & $1.7964 \mathrm{D}-04$ & $1.0047 D+01$ & $5.9144 \mathrm{D}-05$ \\
\hline 2510 & $7.5136 \mathrm{D}+02$ & $5.16740-01$ & & $2.0149 \mathrm{D}-04$ & $1.00410+31$ & $5.9328 D-05$ \\
\hline 2520 & $7.5656 \mathrm{D}+02$ & $5.2203 D-01$ & & $2.2579 D-04$ & $1.00350+01$ & $5.95110-05$ \\
\hline 2530 & $7.61800+02$ & $5.2744 \mathrm{D}-01$ & & $2.52800-04$ & $1.00290+21$ & $5.96940-05$ \\
\hline 2540 & $7.67110+02$ & $5.3297 \mathrm{D}-01$ & & $2.82790-04$ & $1.0023 D+01$ & $5.9878 D-05$ \\
\hline $255 \mathrm{C}$ & $7.7246 \mathrm{D}+02$ & $5.3862 \mathrm{D}-01$ & & $3.16060-04$ & $1.00170+01$ & $6.00510-05$ \\
\hline 2560 & $7.77880+02$ & $5.44390-01$ & & $3.52930-04$ & $1.00110+01$ & $6.0245 \mathrm{D}-0.5$ \\
\hline 2570 & $7.8335 D+02$ & $5.50280-01$ & & $3.9377 D-04$ & $1.0005 D+01$ & $6.0428 \mathrm{D}-0.5$ \\
\hline 2580 & $7.8888 D+02$ & $5.5629 D-01$ & & $4.3895 D-04$ & $9.99930+00$ & $6.26120-05$ \\
\hline 2590 & $7.9448 D+02$ & $5.6243 \mathrm{D}-\mathrm{Cl}$ & & $4.8892 D-04$ & $9.9932 \mathrm{D}+00$ & $6.07960-05$ \\
\hline 2600 & e. $0013 D+02$ & $5.6870 \mathrm{D}-01$ & & $5.4412 \mathrm{D}-04$ & $9.99720+00$ & $6.098 C D-05$ \\
\hline 2610 & $8.0585 D+02$ & $5.75100-01$ & & $6.05050-04$ & $9.98110+30$ & $6.11640-05$ \\
\hline 262 & $8.11640+02$ & $5.8162 D-01$ & & $6.7227 D-C 4$ & $9.97490+00$ & $6.1348 \mathrm{D}-05$ \\
\hline
\end{tabular}


THERMODYNAYIC PROPERTIES OP SOLID URANIOG DIOXIDE

\begin{tabular}{|c|c|c|c|c|c|c|c|c|c|}
\hline $\begin{array}{l}T \\
(k)\end{array}$ & $\begin{array}{c}8-8(298) \\
(J / G)\end{array}$ & $\begin{array}{c}C P \\
(J / G-R)\end{array}$ & $\begin{array}{c}c V \\
(J / G-K)\end{array}$ & $\stackrel{P}{(A T H)}$ & $\begin{array}{c}\mathrm{RHO} \\
(\mathrm{G} / \mathrm{CC})\end{array}$ & $\begin{array}{c}\text { AL P HAP } \\
(1 / K)\end{array}$ & $\begin{array}{c}\text { BETAS } \\
(1 / \text { ATU })\end{array}$ & $\begin{array}{l}\text { BETAT } \\
(1 / \text { ATH) }\end{array}$ & $\begin{array}{l}\text { GA M YAV } \\
\text { (ATU/K) }\end{array}$ \\
\hline 2630 & $8.1748 D+02$ & $5.8828 D-01$ & & $7.46350-04$ & $9.9688 D+00$ & $6.1532 \mathrm{D}-05$ & & & \\
\hline 2640 & 8. $2340 \mathrm{D}+02$ & $5.95070-01$ & & B.2794D-04 & $9.9627 D+00$ & $6.1717 D-05$ & & & \\
\hline 2650 & $B .2939 D+02$ & $6.0199 D-C 1$ & & $9.1773 D-04$ & $9.95650+03$ & $6.1901 \mathrm{D}-05$ & & & \\
\hline 2660 & $8.3 \subseteq 44 D+02$ & $6.0905 D-01$ & & $1.0165 D-03$ & $9.95030+00$ & $5.2086 \mathrm{D}-05$ & & & \\
\hline 2670 & $8.4157 D+02$ & $6.1624 D-C 1$ & & $1.12 \leq 00-03$ & $9.9441 D+00$ & $6.22700-05$ & & & \\
\hline 2680 & $8.4926 \mathrm{D}+02$ & $6.18600-01$ & & $1.2441 D-03$ & $9.93790+00$ & $6.2455 \mathrm{D}-05$ & & & \\
\hline 2690 & 8. $55450+02$ & $\epsilon .1860 D-01$ & & $1.3749 \mathrm{D}-03$ & $9.93170+00$ & $6.26390-05$ & & & \\
\hline 2700 & $8.6163 D+02$ & $6.18600-01$ & & $1.5182 \mathrm{D}-03$ & $9.9255 D+00$ & $6.2824 D-05$ & & & \\
\hline 2710 & $8.6782 D+02$ & $6.18600-01$ & & $1.6753 \mathrm{D}-03$ & $9.91920+00$ & $6.3009 D-05$ & & & \\
\hline 2720 & $8.74010+02$ & $6.1860 D-01$ & & $1.84730-03$ & $9.9130 D+00$ & $6.31940-05$ & & & \\
\hline 2730 & $8.8019 D+C 2$ & $C .1860 D-C 1$ & & $2.0354 \mathrm{D}-03$ & $9.90670+00$ & $6.33790-05$ & & & \\
\hline 2740 & $8.8638 D+02$ & $6.1860 D-01$ & & $2.2412 \mathrm{D}-03$ & $9.9004 D+00$ & $6.3564 D-05$ & & & \\
\hline 2750 & $8.9256 \mathrm{D}+02$ & $6.18600-01$ & & $2.4660 \mathrm{D}-03$ & $9.89410+.00$ & $6.37490-05$ & & & \\
\hline 2760 & $8.98750+02$ & $6.1860 \mathrm{D}-01$ & & $2.7115 D-03$ & $9.83780+00$ & $6.39350-05$ & & & \\
\hline 2770 & S.0494D+02 & $6.18600-01$ & & $2.97950-03$ & $9.88140+00$ & $6.41200-05$ & & & \\
\hline 2780 & $9.1112 D+02$ & $6.18600-01$ & & $3.27160-03$ & $9.87510+00$ & $6.43050-05$ & & & \\
\hline 2790 & $9.1731 D+02$ & $6.1860 \mathrm{D}-\mathrm{C} 1$ & & $3.5900 \mathrm{D}-03$ & $9.8687 D+30$ & $6.44910-05$ & & & \\
\hline 2800 & $9.23490+02$ & $6.18600-01$ & & $3.93680-03$ & $9.86240+00$ & $6.46760-05$ & & & \\
\hline 2810 & $9.2968 \mathrm{D}+02$ & $6.1860 D-01$ & & 4. $3142 D-03$ & $9.85600+90$ & $6.48620-05$ & & & \\
\hline 2820 & $9.3587 D+02$ & $6.1860 \mathrm{D}-01$ & & $4.72480-03$ & $9.84960+00$ & $6.504 \mathrm{BD}-0.5$ & & & \\
\hline 2830 & $9.4205 D+02$ & $6.1860 \mathrm{D}-01$ & & $5.17110-C 3$ & $9.84310+130$ & $6.5233 \mathrm{D}-05$ & & & \\
\hline 2640 & $9.4824 D+02$ & $6.1860 \mathrm{D}-01$ & & $5.6560 D-03$ & $9.83670+00$ & $6.54190-05$ & & & \\
\hline 2850 & $9.5442 \mathrm{D}+02$ & $6.1860 \mathrm{D}-09$ & & $6.1824 \mathrm{D}-03$ & $9.83020+00$ & $6.5605 D-05$ & & & \\
\hline 2860 & $9.60610+02$ & $\epsilon .18600-01$ & & $6.7536 D-03$ & $9.8238 \mathrm{D}+00$ & $6.57910-05$ & & & \\
\hline 2870 & $9.66800+02$ & $6.1860 D-01$ & & $7.37310-03$ & $9.8173 \mathrm{D}+00$ & $6.5977 D-05$ & & & \\
\hline 2880 & $9.7298 D+02$ & $6.18600-01$ & & $8.04450-03$ & $9.8103 D+30$ & $6.61630-05$ & & & \\
\hline
\end{tabular}


THERGODYNAMIC PROPBHTIES OF SOLID URANIUU DIOXIDE

\begin{tabular}{|c|c|c|c|c|c|c|}
\hline $\begin{array}{c}T \\
(K)\end{array}$ & $\begin{array}{c}H-H(298) \\
(J / G)\end{array}$ & $\begin{array}{c}C P \\
(J / G-K)\end{array}$ & $\begin{array}{c}C V \\
(J / G-K)\end{array}$ & $\begin{array}{c}P \\
\text { (ATM) }\end{array}$ & $\begin{array}{c}\text { RHO } \\
(\mathrm{G} / \mathrm{CC})\end{array}$ & $\begin{array}{c}\text { ALPHAP } \\
(1 / K)\end{array}$ \\
\hline 2890 & $9.7917 \mathrm{D}+02$ & $6.1860 D-C 1$ & & $8.7718 D-03$ & $9.80430+J 0$ & $6.6350 D-05$ \\
\hline 2900 & $5.85350+02$ & $6.18600-01$ & & $9.5590 \mathrm{D}-03$ & $9.7978 D+00$ & $6.65360-05$ \\
\hline 2510 & $9.9154 D+02$ & $\epsilon .1860 D-C 1$ & & $1.0411 D-02$ & $9.79120+00$ & $6.6722 \mathrm{D}-05$ \\
\hline 2920 & $9.97730+02$ & $\leqslant .1860 \mathrm{D}-01$ & & $1.1332 \mathrm{D}-02$ & $9.7847 D+00$ & $6.69090-05$ \\
\hline 2930 & $1.00390+03$ & $6.1860 \mathrm{D}-01$ & & $1.2327 \mathrm{D}-02$ & $9.7781 D+00$ & $6.70950-05$ \\
\hline 2940 & $1.01010+03$ & $\epsilon .1860 D-01$ & & $1.3402 \mathrm{D}-02$ & $9.77150+00$ & $6.7282 \mathrm{D}-05$ \\
\hline 2950 & $1.0163 D+03$ & $6.1860 D-01$ & & $1.4563 \mathrm{D}-02$ & $9.76490+00$ & $6.7468 D-05$ \\
\hline 2960 & $1.02250+03$ & $6.1860 \mathrm{D}-01$ & & $1.5815 \mathrm{D}-02$ & $9.7583 \mathrm{D}+00$ & $6.7655 \mathrm{D}-05$ \\
\hline 2970 & $1.0287 D+03$ & $6.18600-01$ & & $1.7166 \mathrm{D}-02$ & $9.75170+20$ & $6.78420-05$ \\
\hline 2980 & $1.0348 D+03$ & $6.1860 \mathrm{D}-01$ & & $1.8621 \mathrm{D}-02$ & $9.74510+00$ & $6.8029 D-05$ \\
\hline 2990 & $1.0410 D+03$ & $6.18600-01$ & & $2.0189 \mathrm{D}-02$ & $9.7384 \mathrm{D}+00$ & $6.8215 D-05$ \\
\hline 3000 & $1.04720+03$ & $6.1860 \mathrm{D}-01$ & & $2.1878 \mathrm{D}-02$ & $9.7317 D+00$ & $6.8402 D-05$ \\
\hline 3010 & $1.0534 D+03$ & $6.1860 \mathrm{D}-01$ & & $2.3694 \mathrm{D}-\mathrm{C} 2$ & $9.72510+00$ & $6.8589 D-05$ \\
\hline 3020 & $1.0595 \mathrm{D}+03$ & $6.1860 \mathrm{D}-01$ & & $2.5 \in 48 D-C 2$ & $9.7184 \mathrm{D}+00$ & $6.87770-05$ \\
\hline 3030 & $1.0658 \mathrm{D}+03$ & $6.1860 \mathrm{D}-01$ & & $2.7749 \mathrm{D}-02$ & $9.7116 \mathrm{D}+00$ & $6.8964 D-05$ \\
\hline 3040 & $1.07200+03$ & $6.18600-01$ & & $3.0006 D-02$ & $9.70490+00$ & $6.91510-05$ \\
\hline 3050 & $1.07810+03$ & $6.18600-01$ & & $3.2430 \mathrm{D}-\mathrm{C} 2$ & $9.6982 D+00$ & $6.9338 D-05$ \\
\hline 3060 & $1.08430+03$ & $6.1860 \mathrm{D}-01$ & & $3.5 C 32 D-02$ & $9.6914 D+00$ & $6.9526 \mathrm{D}-05$ \\
\hline $307 c$ & $1.0905 \mathrm{D}+03$ & $6.1860 \mathrm{D}-01$ & & $3.7824 D-02$ & $9.6847 D+00$ & $6.97130-05$ \\
\hline 3080 & $1.0967 D+C 3$ & $6.18600-01$ & & $4.0819 D-02$ & $9.57790+00$ & $6.99000-05$ \\
\hline 3090 & $1.10290+03$ & $6.1060 D-C 1$ & & $4.4028 D-02$ & $9.67110+00$ & $7.00880-05$ \\
\hline 3100 & $1.10910+03$ & $6.186 \mathrm{CD}-01$ & & $4.7466 \mathrm{D}-02$ & $9.66430+00$ & $7.0276 D-05$ \\
\hline 3110 & $1.11530+03$ & $6.1860 D-01$ & & $5.11490-02$ & $9.6575 D+00$ & $7.04630-05$ \\
\hline 3120 & $1.1214 D+03$ & $6.1860 \mathrm{D}-01$ & & $5.50910-02$ & $9.65060+00$ & $7.06510-05$ \\
\hline
\end{tabular}


THERMODYHAMIC PROPERTIES OF LIUUID URANIUH DIOXIDE

\begin{tabular}{|c|c|c|c|c|c|c|c|c|c|c|}
\hline $\begin{array}{c}T \\
(\mathrm{~K})\end{array}$ & $\begin{array}{c}\mathrm{B}-\mathrm{H}(298) \\
(\mathrm{J} / \mathrm{G})\end{array}$ & $\begin{array}{c}C P \\
(J / G-K)\end{array}$ & $\begin{array}{c}C V \\
(J / G-R)\end{array}$ & $\underset{(A T H)}{P}$ & $\begin{array}{c}\mathrm{DH} \\
(\mathrm{J} / \mathrm{G})\end{array}$ & $\begin{array}{c}\text { RHO } \\
(G / C C)\end{array}$ & $\begin{array}{l}\text { ALPHAP } \\
(1 / K)\end{array}$ & $\begin{array}{l}\text { BETAS } \\
(1 / \text { ATM })\end{array}$ & $\begin{array}{c}\text { BETAT } \\
\text { (1/ATE) }\end{array}$ & $\begin{array}{l}\text { GAMSAY } \\
\text { (1/ATA) }\end{array}$ \\
\hline 20 & $.3986 D+C 3$ & $.8495 D-01$ & $.8939 D-01$ & $.5175 D-02$ & $1.9347 D+03$ & $8.7388 D+00$ & $1.05000-04$ & $3.3512 D-06$ & $4.1737 \mathrm{D}-06$ & $2.5158 D+01$ \\
\hline 130 & $1.40340+03$ & $4.6495 D-01$ & $3.8967 D-01$ & $.8939 \mathrm{D}-02$ & $1.9329 D+03$ & $8.7298 D+00$ & $1.0496 \mathrm{D}-04$ & $3.3756 \mathrm{D}-06$ & $4.20090-06$ & $2.4986 D+01$ \\
\hline 140 & $1.4083 D+C 3$ & $4.8495 \mathrm{D}-01$ & $.8996 \mathrm{D}-01$ & $.27190-02$ & $.93120+03$ & $8.72080+30$ & $1.04930-04$ & $3.4002 D-06$ & $4.22840-06$ & $2.48140+01$ \\
\hline 150 & $1.41310+03$ & $4.84950-01$ & $.9025 D-01$ & $6.6823 \mathrm{D}-02$ & $.9295 D+03$ & $8.7118 D+00$ & $1.04890-04$ & $3.42500-06$ & $4.2562 \mathrm{D}-06$ & $2.4644 D+01$ \\
\hline 160 & $1.41800+03$ & $4.8495 D-01$ & $.9054 \mathrm{D}-01$ & $.11620-02$ & $.9277 D+03$ & $3.7029 D+00$ & $1.04850-04$ & $3.4502 D-06$ & $4.28420-06$ & $2.4474 \mathrm{D} \bullet 01$ \\
\hline 170 & $1.4228 D+03$ & $4.8495 D-01$ & $3.908 .3 \mathrm{D}-01$ & $7.5750 D-02$ & $.92600+03$ & $8.69390+00$ & $1.0482 \mathrm{D}-04$ & $3.47550-06$ & $4.31250-06$ & $2.43050+01$ \\
\hline 180 & $.42770+03$ & $4.8495 \mathrm{D}-01$ & $3.9112 \mathrm{D}-01$ & $8.0597 \mathrm{D}-02$ & $.9243 D+0.3$ & $8.68490+00$ & $1.04780-04$ & $3.50110-06$ & $4.34110-06$ & $2.4137 \mathrm{D}+01$ \\
\hline 190 & 1. $43250+03$ & $.8495 D-01$ & .9141 D-01 & $.57160-02$ & $.9225 D+03$ & $8.6759 D+00$ & $1.0474 \mathrm{D}-04$ & $3.52700-06$ & $4.3699 D-06$ & $2.39690+01$ \\
\hline 200 & $1.43740+03$ & $4.84950-01$ & $3.91710-01$ & $.1120 \mathrm{D}-\mathrm{C} .2$ & $.9208 D+03$ & $8.6669 D+00$ & $1.0471 \mathrm{D}-04$ & $3.5532 \mathrm{D}-0.06$ & $4.39890-06$ & $2.38030+01$ \\
\hline 210 & $1.44220+03$ & $.8495 D-01$ & $.9201 \mathrm{D}-01$ & $.6822 D-02$ & $.9191 D+03$ & $8.6579 D+00$ & $1.04670-04$ & $3.5796 \mathrm{D}-06$ & $4.42830-06$ & $2.36370+01$ \\
\hline 230 & $1.4519 D+03$ & $.8495 \mathrm{D}-01$ & $3.9260 \mathrm{D}-01$ & $1.09180-01$ & $.91560+03$ & $8.6400 \mathrm{D}+00$ & $1.04600-34$ & $3.63330-06$ & $4.48780-06$ & $2.3307 D+01$ \\
\hline 240 & $1.4568 D+03$ & $+950-01$ & $3.92910-01$ & $1.1586 \mathrm{D}-01$ & $1.9138 \mathrm{D}+03$ & $8.63100+00$ & $1.0456 \mathrm{D}-04$ & $3.66050-06$ & $4.5180 \mathrm{D}-06$ & $2.31430+01$ \\
\hline 250 & & $.8495 \mathrm{D}-01$ & $3.93210-01$ & $1.22900-01$ & $1.91210+03$ & $8.62200+00$ & $1.0452 \mathrm{D}-04$ & $3.68800-06$ & $4.54850-06$ & $2.2980 D+01$ \\
\hline 260 & & $.8495 D-01$ & $3.9351 \mathrm{D}-01$ & $1.3032 D-01$ & $1.91040+03$ & $8.6130 \mathrm{D}+00$ & $1.0449 D-04$ & $3.7159 \mathrm{D}-066$ & $4.5793 \mathrm{D}-06$ & $2.2818 D+01$ \\
\hline 270 & & $.84950-01$ & $3.93820-01$ & 1. $3813 \mathrm{D}-\mathrm{C} 1$ & $1.9086 \mathrm{D}+03$ & $8.60400+00$ & $1.04450-04$ & $3.7440 \mathrm{D}-06$ & $4.6104 \mathrm{D}-06$ & $2.26560+01$ \\
\hline 280 & & $.84950-01$ & $3.9413 \mathrm{D}-01$ & $1.4634 \mathrm{D}-01$ & $1.90690+03$ & $8.59500+00$ & $1.34420-04$ & $3.77240-06$ & $4.64170-06$ & $2.2495 \mathrm{D}+01$ \\
\hline 290 & & $.8495 \mathrm{D}-01$ & $3.9443 \mathrm{D}-01$ & $.54980-01$ & $1.9052 D+C 3$ & $8.586 C D+00$ & $1.04380-04$ & $3.80110-06$ & $4.6734 \mathrm{D}-06$ & $2.2335 D+C 1$ \\
\hline 300 & $1.48590+03$ & $.8495 D-01$ & $3.9475 \mathrm{D}-01$ & $1.64070-01$ & $1.90340+03$ & B. $57700+00$ & $1.04340-04$ & $3.8302 \mathrm{D}-06$ & $4.7054 \mathrm{D}-06$ & $2.21750+01$ \\
\hline 310 & & $84950-01$ & $3.9506 \mathrm{D}-01$ & $1.7361 \mathrm{D}-\mathrm{C} 1$ & $1.9017 D+03$ & $8.5681 \mathrm{D}+00$ & $1.04310-04$ & $3.85950-06$ & $4.7377 D-06$ & 2. $2016 \mathrm{D}+01$ \\
\hline 320 & $1.4956 \mathrm{D}+\mathrm{C} 3$ & $4.84950-01$ & $3.9537 \mathrm{D}-01$ & $1.8365 n-01$ & $1.89990+03$ & $8.55910+00$ & $1.04270-04$ & $3.88910-06$ & $4.77030-06$ & 2. $1858 D+01$ \\
\hline 3330 & $1.50040+03$ & $4 . E 495 D-01$ & $3.9568 \mathrm{D}-01$ & $1.9418 D-C 1$ & $1.8982 \mathrm{D}+03$ & $8.55010+00$ & $1.0423 \mathrm{D}-04$ & $3.91910-06$ & $4.8032 \mathrm{D}-06$ & 2. $17010+01$ \\
\hline 335 & $1.51010+03$ & $4.84950-01$ & $3.9632 \mathrm{D}-01$ & $2.1685 D-01$ & $1.8947 D+03$ & $8.53210+00$ & $1.0416 D-04$ & $3.98000-05$ & $4.8701 \mathrm{D}-06$ & 2. $13880+01$ \\
\hline 360 & $1.51500+03$ & $4.8495 \mathrm{D}-\mathrm{C} 1$ & $3.9664 \mathrm{D}-01$ & $2.29030-01$ & & B. $5231 \mathrm{D}+00$ & $1.04130-04$ & $4.0109 D-06$ & $4.90400-36$ & $2.12330+01$ \\
\hline 370 & $1.5198 D+03$ & $4.8495 D-01$ & $.96960-01$ & $.41810-01$ & $1.89130+03$ & $8.51410+00$ & $1.04090-04$ & $4.0422 \mathrm{D}-06$ & $382 \mathrm{D}-06$ & $2.1078 D+01$ \\
\hline
\end{tabular}


THERMODYNAMIC PRONERIIES OF LIQUID URANIUM DIOXIDE

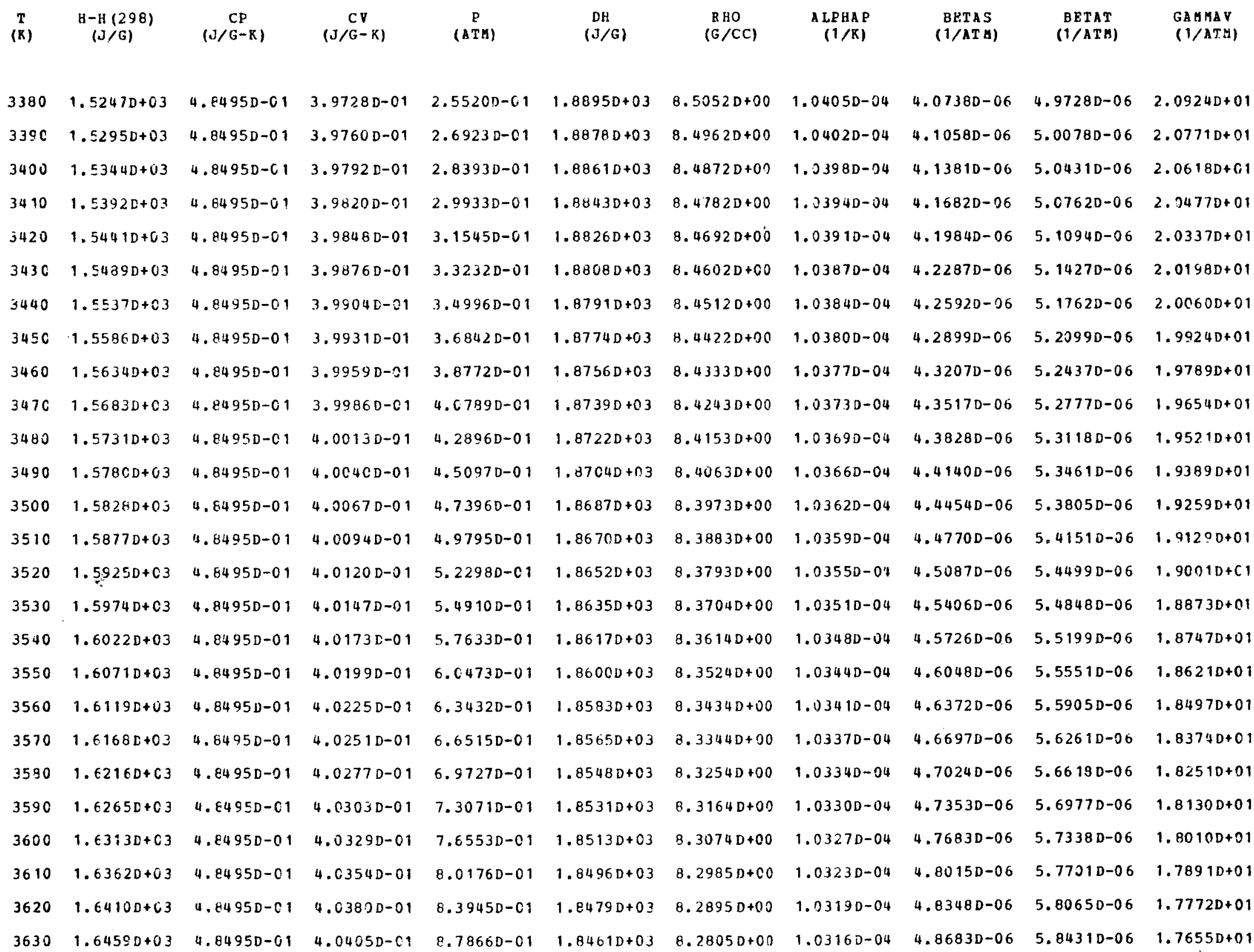


THEKMODYNAMIC PBORERTIES OP LIQUID URANIUA DIOXIDE

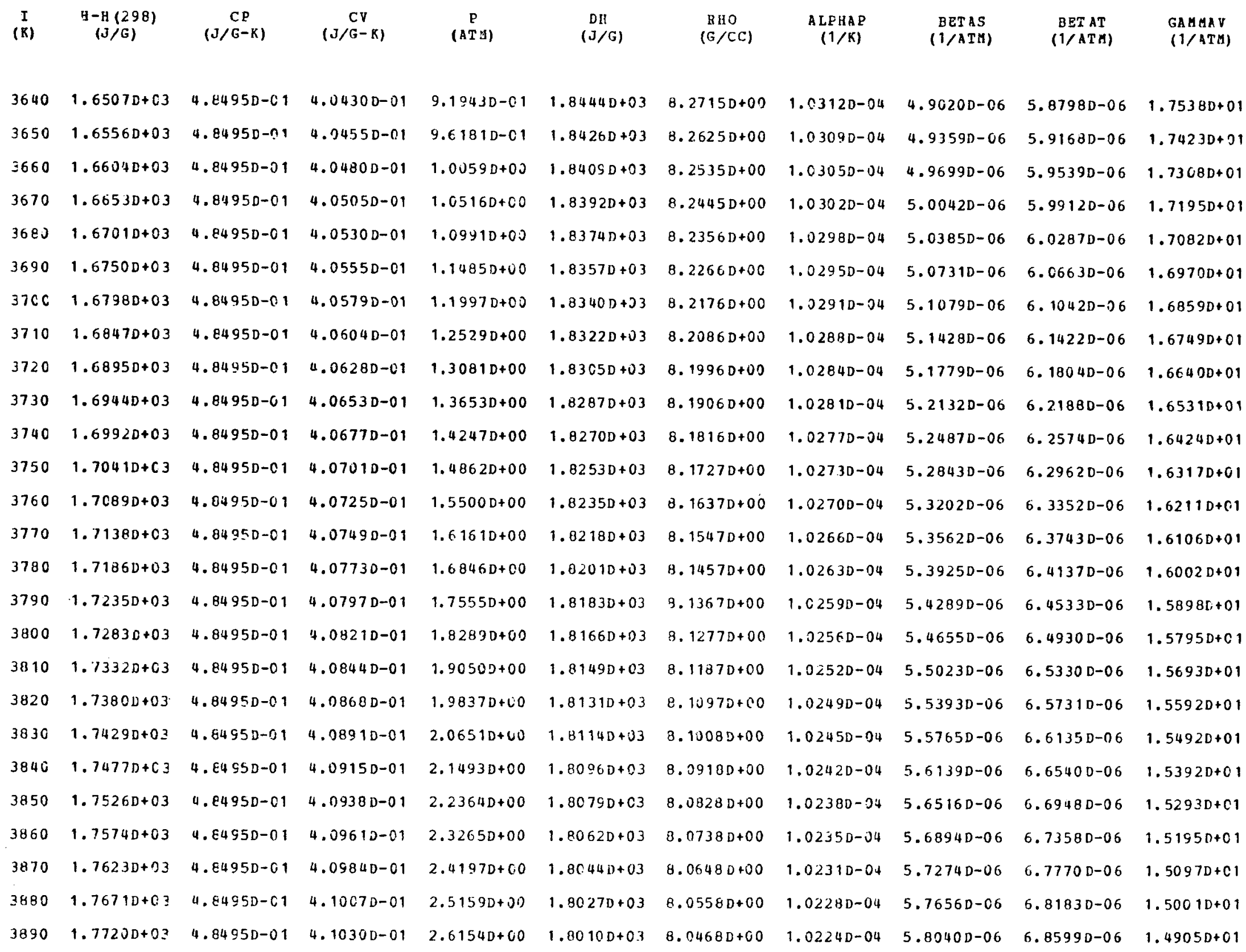


THERMODYNAGIC EROPERTIRS OF LIQUID URANIUA DIOXIDE

\begin{tabular}{|c|c|c|c|c|c|c|c|c|c|c|}
\hline $\begin{array}{l}T \\
(K)\end{array}$ & $\begin{array}{c}B-H(298) \\
(J / G)\end{array}$ & $\begin{array}{c}C P \\
(J / G-K)\end{array}$ & $\begin{array}{c}C V \\
(J / G-K)\end{array}$ & $\stackrel{p}{(\operatorname{ATM})}$ & $\begin{array}{l}\mathrm{DH} \\
(\mathrm{J} / \mathrm{G})\end{array}$ & $\begin{array}{c}\text { EHO } \\
(\mathrm{G} / \mathrm{CC})\end{array}$ & $\begin{array}{c}\text { A LE'HAP } \\
(1 / K)\end{array}$ & $\begin{array}{c}\text { BETAS } \\
(1 / \text { ATE })\end{array}$ & $\begin{array}{c}\text { BETAT } \\
(1 / \text { ATH })\end{array}$ & $\begin{array}{l}\text { GAHMAV } \\
(1 / \operatorname{ATB})\end{array}$ \\
\hline 3900 & $1.7768 D+03$ & $4.84950-01$ & $4.1053 \mathrm{D}-01$ & $2.7181 D+00$ & $1.7992 D+03$ & $9.03790+00$ & $1.0221 \mathrm{D}-04$ & $5.8427 D-06$ & $6.90180-06$ & $1.48090+01$ \\
\hline 3910 & $1.7817 D+C 3$ & $4.8495 D-01$ & $4.1076 \mathrm{D}-01$ & $2.8242 \mathrm{D}+00$ & $1.7975 D+03$ & $8.0289 D+00$ & $1.02170-04$ & $5.8815 D-06$ & $6.94380-06$ & $1.4715 D+01$ \\
\hline 3920 & $1.7865 D+C 3$ & $4.84950-01$ & $4.10990-01$ & $2.9338 D+00$ & $1.7958 D+03$ & $8.01990+00$ & $1.02140-04$ & $5.9206 \mathrm{D}-06$ & $6.98610-06$ & $1.4621 \mathrm{D}+01$ \\
\hline 3930 & $1.79140+03$ & $4.8495 \mathrm{D}-01$ & $4.1122 \mathrm{D}-01$ & $3.0470 D+C 0$ & $1.79400+03$ & $8.01090+00$ & $1.0211 \mathrm{D}-04$ & $5.9599 D-06$ & $7.02850-06$ & $1.45270+01$ \\
\hline 3940 & $1.79620+03$ & $4.84950-01$ & $4.1144 \mathrm{E}-01$ & $3.1638 D+00$ & $1.7923 \mathrm{D}+03$ & $8.0019 \mathrm{D}+00$ & $1.02070-04$ & $5.99940-06$ & $7.07120-06$ & $1.4435 D+01$ \\
\hline 3950 & $1.80110+03$ & $4.84950-01$ & $4.11670-01$ & $3.28430+20$ & $1.7905 \mathrm{D}+03$ & $7.99290+00$ & $1.02040-04$ & $6.03910-06$ & 7. $11410-06$ & $1.43430+01$ \\
\hline 3960 & $1.80590+03$ & $4.8495 \mathrm{D}-01$ & $4.1189 D-C 1$ & $3.4086 \mathrm{D}+00$ & $1.7888 D+03$ & $7.93390+00$ & $1.02000-04$ & $6.07910-06$ & $7.1573 \mathrm{D}-06$ & $1.4251 D+01$ \\
\hline 3970 & $1.81000+03$ & $4.64950-01$ & $4.1212 D-C 1$ & $3.5368 D+00$ & $1.78710+03$ & $7.9749 D+00$ & $1.0197 D-04$ & $6.11920-06$ & 7. $20060-06$ & $1.41610+01$ \\
\hline 3980 & 1. $\& 156 D+03$ & 4. $8495 \mathrm{D}-01$ & $4.1234 D-C 1$ & $3.66910+00$ & $1.7853 D+03$ & 7. $96600+00$ & $1.01930-34$ & $6.15960-06$ & $7.24420-06$ & $1.40710+C 1$ \\
\hline 3990 & $1.8205 D+C 3$ & $4.84950-01$ & $4.12560-01$ & $3.8055 D+00$ & $1.78360+03$ & $7.9570 \mathrm{D}+00$ & $1.01900-04$ & $6.2002 \mathrm{D}-06$ & $7.28810-06$ & $1.39810+01$ \\
\hline 4000 & $1.82530+03$ & $4.84950-01$ & $4.1278 D-01$ & $3.94610+00$ & $1.7819 D+03$ & $7.94800+00$ & $1.21860-04$ & $6.2411 \mathrm{D}-06$ & $7.3321 \mathrm{D}-06$ & 1. $3893 D+01$ \\
\hline 4010 & $1.6302 D+03$ & $4.84950-01$ & 4. $13010-01$ & $4.0910 D+00$ & $1.78010+03$ & $7.93900+00$ & $1.01830-04$ & $6.28210-06$ & $7.37640-06$ & $1.3805 D+01$ \\
\hline 4020 & $1.83500+03$ & $4.8495 D-01$ & $4.13230-01$ & $4.24030+00$ & $1.77840+\dot{v} 3$ & 7. $9300 D+C 0$ & $1.01790-04$ & $6.3234 D-06$ & $7.4210 \mathrm{D}-06$ & $1.3717 D+01$ \\
\hline 4030 & $1.8399 D+03$ & $4.84950-01$ & $4.1345 D-01$ & $4.39410+C 3$ & $1.7767 D+03$ & $7.92100+00$ & $1.01760-04$ & $6.3650 D-06$ & 7. $46570-06$ & $1.3630 D+C l$ \\
\hline 4040 & $1.84470+03$ & $4.8495 D-01$ & $4.1367 D-C 1$ & $4.5525 D+00$ & $1.7749 D+03$ & $1.91200+50$ & $1.01720-04$ & $6.4067 D-06$ & $7.51070-06$ & $1.3544 D+01$ \\
\hline 4050 & $1.8496 \mathrm{D}+\mathrm{C} 3$ & $4.8495 D-01$ & $4.1389 D-01$ & $4.7157 D+03$ & $1.7732 \mathrm{D}+03$ & $7.90310+00$ & $1.01690-04$ & $6.4488 D-06$ & $7.55600-06$ & $1.34580+01$ \\
\hline 4060 & $1.85440+03$ & $4.84950-01$ & $4.14100-01$ & $4.8837 D+00$ & $1.7714 D+73$ & $7.83410+00$ & $1.01660-04$ & $6.49100-06$ & $7.6015 D-06$ & $1.3373 D+01$ \\
\hline 4073 & $1.8593 \mathrm{D}+03$ & $4.84950-01$ & $4.14320-01$ & $5 . C 5660+C 0$ & $1.76970+03$ & $7.88510+00$ & $1.0162 \mathrm{D}-04$ & $6.5335 D-06$ & $7.64720-06$ & $1.3289 D+01$ \\
\hline 4080 & $1.86410+03$ & $4.84950-01$ & $4.14540-01$ & $5.23460+00$ & $1.76800+03$ & $7.8761 D+00$ & $1.0159 \mathrm{D}-04$ & $6.5762 D-06$ & $7.6932 \mathrm{D}-06$ & $1.32050+01$ \\
\hline 4090 & $1.8690 D+C 3$ & $4.8495 D-01$ & $4.1476 D-01$ & $5.4178 \mathrm{D}+00$ & $1.7662 \mathrm{D}+03$ & $7.86110+00$ & $1.01550-04$ & $6.61920-06$ & $7.7395 D-06$ & $1.31210+01$ \\
\hline 4100 & $1.87380+C 3$ & $4.24950-01$ & $4.1497 D-01$ & $5.6062 D+C O$ & $1.7645 D+03$ & $7.85810+00$ & $1.0152 D-04$ & $6.6625 D-06$ & $7.7860 \mathrm{D}-06$ & $1.30 .390+01$ \\
\hline 4110 & $1 . E 787 D+03$ & $4.84950-01$ & $4.1519 D-C 1$ & $5.80010+00$ & $1.7628 D+03$ & $7.84910+00$ & $1.01480-04$ & $6.70590-06$ & $7.8327 \mathrm{D}-06$ & $1.29560+01$ \\
\hline 4120 & $1.88350+03$ & $4.8495 D-01$ & 4. 1540 D-0 1 & $5.9994 D+00$ & $1.76100+03$ & $7.84010+00$ & $1.0145 D-04$ & $6.74970-06$ & $7.8797 D-06$ & $1.28750+01$ \\
\hline 4130 & $1 . \varepsilon 8840+03$ & $4.8495 \mathrm{D}-01$ & $4.15620-01$ & $6.20440+00$ & $1.75930+03$ & $7.83120+00$ & $1.01410-04$ & $6.7937 \mathrm{D}-06$ & $7.92700-06$ & $1.27940+01$ \\
\hline 4140 & $1.8932 \mathrm{D}+\mathrm{c} 3$ & $4.84950-01$ & $4.1583 \mathrm{D}-01$ & $6.41510+00$ & $1.75750+03$ & $7.8222 \mathrm{D}+00$ & $1.0138 D-04$ & $6.8379 D-06$ & $7.9745 D-06$ & $1.2713 D+01$ \\
\hline+150 & $1.89810+03$ & $4.84950-C 1$ & $4.16040-01$ & $6.6317 D+00$ & $1.7558 D+03$ & $7.8132 D+00$ & $1.01350-04$ & $6.88240-06$ & $8.02230-06$ & $1.2633 D+01$ \\
\hline
\end{tabular}


THERMODYNAMIC FROPERTIES OF IIQUID URANIUM DIOXIDE

\begin{tabular}{|c|c|c|c|c|c|c|c|c|c|c|}
\hline$\stackrel{T}{T}$ & $\begin{array}{c}B-H(298) \\
(J / G)\end{array}$ & $\begin{array}{c}C P \\
(J / G-K)\end{array}$ & $\begin{array}{c}C V \\
(J / G-K)\end{array}$ & $\underset{(\mathrm{ATM})}{\mathrm{P}}$ & $\begin{array}{c}D H \\
(J / G)\end{array}$ & $\begin{array}{c}\mathrm{RHO} \\
(\mathrm{G} / \mathrm{CC})\end{array}$ & $\begin{array}{r}\text { ALPBAP } \\
(1 / K)\end{array}$ & $\begin{array}{c}\text { BETAS } \\
\text { (1/ATH) }\end{array}$ & $\begin{array}{l}\text { BETAT } \\
\text { (1/ATH) }\end{array}$ & $\begin{array}{l}\cdot \text { GAMAAV } \\
\\
(1 / \text { ATM })\end{array}$ \\
\hline 150 & $1.90290+0 \overline{3}$ & $4.8495 \mathrm{D}-01$ & $4.1626 \mathrm{D}-01$ & $6.85430+00$ & $1.7541 \mathrm{D}+03$ & $7.8042 D+00$ & $1.01310-04$ & $6.9272 \mathrm{D}-06$ & $9.07040-06$ & 1. $25540+01$ \\
\hline 170 & $1.9078 D+C 3$ & $4.84950-01$. & $4.1647 D-01$ & $7.08300+00$ & $1.75230+03$ & $7.7952 \mathrm{D}+00$ & $1.0128 D-04$ & $6.9722 \mathrm{D}-06$ & $8.11870-06$ & $1.24750+01$ \\
\hline 180 & $1 . \$ 126 D+03$ & $4.84950-01$ & $4.1668 \mathrm{D}-01$ & 7. $31800+00$ & $1.7506 D+03$ & $7.7362 \mathrm{D}+00$ & $1.01240-04$ & $7.01750-06$ & $8.16730-06$ & $1.23960+01$ \\
\hline 190 & $1.91750+03$ & $4.84950-01$ & $4.16890-01$ & $7.55930+00$ & $1.7489 D+03$ & $7.77720+00$ & $1.01210-04$ & $7.0631 \mathrm{D}-06$ & $9.21620-06$ & $1.2318 D+01$ \\
\hline 200 & $1.92230+03$ & $4.84950-01$ & $4.1710 \mathrm{D}-01$ & $7.80710+00$ & $1.74710+03$ & $7.76830+00$ & $1.01180-04$ & $7.1089 \mathrm{D}-06$ & $8.2653 \mathrm{D}-06$ & $1.22410+01$ \\
\hline 210 & $1.9272 D+C 3$ & $4.84350-01$ & $4.17310-01$ & $8.0616 D+00$ & $1.74540+03$ & $7.75930+00$ & $1.01140-04$ & 7. $1551 \mathrm{D}-06$ & $8.3147 D-06$ & 1. $2164 D+01$ \\
\hline 220 & $1.932 C D+03$ & $4.84950-01$ & $4.1752 D-01$ & R. $3228 D+00$ & $1.7437 D+03$ & $7.75030+00$ & $1.01110-04$ & $7.2015 D-06$ & $8.3645 \mathrm{D}-06$ & $1.2088 D+01$ \\
\hline 230 & $1.93690+03$ & 4. E495D-01 & $4.1773 D-01$ & $8.5909 D+00$ & $1.7419 D+03$ & $7.74130+20$ & $1.01070-04$ & $7.2481 D-06$ & $8.4144 \mathrm{D}-06$ & $1.2012 D+01$ \\
\hline 240 & $1.34170+03$ & $4.84950-01$ & $4.17940-01$ & $8.8661 D+00$ & $1.74020+03$ & $7.73230+00$ & $1.01040-04$ & $7.2951 D-06$ & $8.46470-06$ & 1. $1937 \mathrm{D}+01$ \\
\hline 2.50 & $1.94660+\hat{u} 3$ & $.84950-01$ & $4.1815 D-31$ & $9.14840+00$ & $1.738+D+03$ & $7.72330+00$ & $1.0101 D-04$ & $7.34230-06$ & $8.5153 D-06$ & 1. $1862 \mathrm{D}+01$ \\
\hline 270 & $1.9563 D+03$ & $1.8495 \mathrm{D}-01$ & $4.18560-01$ & $9.73510+00$ & $1.73500+73$ & i) $530+20$ & $1.0094 D-04$ & $7.43760-06$ & $1730-06$ & 1. $1713 \mathrm{D}+01$ \\
\hline 280 & $.9611 D+C 3$ & $.84950-01$ & $4.1877 \mathrm{D}-01$ & $1.00400+01$ & $1.7332 D+03$ & $7.6964 \mathrm{D}+00$ & $090 D-04$ & $857 D-06$ & $8 D-06$ & $100+01$ \\
\hline 296 & $1.96600+03$ & $5 D-01$ & $8970-01$ & $1.0352 D+01$ & $1.7315 D+93$ & $7.68740+00$ & $.00870-04$ & $5341 \mathrm{D}-06$ & $2050-06$ & $15670+01$ \\
\hline 300 & $1.9708 v+03$ & $4.84950-01$ & $.19180-01$ & $1.06720+01$ & $1.7298 v+03$ & $7.67840+00$ & $00840-04$ & $280-06$ & $5 D-06$ & $4940+01$ \\
\hline 310 & $1.97570+03$ & $4.84950-01$ & $4.19390-01$ & $1.10010+01$ & $1.72800+03$ & $7.66940+00$ & $00800-04$ & $180-06$ & $9 D-06$ & \\
\hline 320 & $1.9805 D+03$ & $.84950-\dot{1}$ & $4.1953 D-01$ & $1.1337 D+01$ & $1.7263 c+0.3$ & $7.66040+00$ & $1.0077 \mathrm{D}-04$ & $7.68110-06$ & $7760-06$ & $13510+01$ \\
\hline 4330 & $1.98540+03$ & $4.84950-01$ & $4.19790-01$ & $1.16320+01$ & $1.7246 D+03$ & $7.6514 \mathrm{D}+00$ & $0073 D-04$ & $1.73070-06$ & $8.9305 D-06$ & $1.1280 D+01$ \\
\hline 340 & $1.9902 D+03^{\circ}$ & $4.8495 \mathrm{D}-01$ & $4.20000-01$ & $1.20350+01$ & $1.7228 D+03$ & $7.64240+00$ & $1.00700-174$ & $78060-06$ & $8.9838 D-06$ & $1.1209 D+01$ \\
\hline 4350 & $1.99510+23$ & $4.84950-31$ & $4.20200-01$ & $1.23970+01$ & $1.72110+03$ & $7.6335 \mathrm{D}+00$ & $1.0067 D-04$ & $8368 D-06$ & $9.0374 D-06$ & \\
\hline 4$] \in C$ & $1.9999 \mathrm{D}+03$ & $4.84950-01$ & $4.20410-01$ & $1.2768 \mathrm{D}+01$ & $1.71930+03$ & $7.62450+00$ & & $88140-00$ & $9.09130-06$ & $1.1069 D+01$ \\
\hline 4370 & $2.0048 D+03$ & $4.8495 D-01$ & $4.20610-01$ & $1.31470+01$ & $1.71760+03$ & & & & $9.1456 \mathrm{D}-06$ & \\
\hline 4406 & $2.0193 D+03$ & $4.84950-01$ & $4.21220-01$ & $1.43410+01$ & $1.71240+03$ & $7.5835 D+00$ & $1.00500-04$ & $8.0867 \mathrm{D}-06$ & $9.31030-06$ & $1.07940+01$ \\
\hline 1410 & $2.02410+03$ & $4.8495 \mathrm{D}-01$ & $4.2142 D-01$ & $1.47580+01$ & $1.7107 D+03$ & $7.57950+.00$ & $1.00460-04$ & $8.1388 D-06$ & $9.3658 D-06$ & $1.0727 D+01$ \\
\hline
\end{tabular}


THERMOUYNAMIC FROPERTIES OF LIQTID URANIUM DIOXIDE

\begin{tabular}{|c|c|c|c|c|c|c|c|c|c|c|}
\hline $\begin{array}{l}T \\
(K)\end{array}$ & $\begin{array}{c}H-H(298) \\
(J / G)\end{array}$ & $\begin{array}{c}C P \\
(J / G-K)\end{array}$ & $\begin{array}{c}C V \\
(J / G-K)\end{array}$ & $\begin{array}{c}\mathrm{P} \\
\text { (ATid) }\end{array}$ & $\begin{array}{l}\mathrm{DH} \\
(\mathrm{J} / \mathrm{G})\end{array}$ & $\begin{array}{c}\text { RHO } \\
(\mathrm{G} / \mathrm{CC})\end{array}$ & $\begin{array}{c}\text { ALP HAP } \\
(1 / K)\end{array}$ & $\begin{array}{c}\text { BETAS } \\
(1 / A T A)\end{array}$ & $\begin{array}{l}\text { BETAT } \\
(1 / \text { ATU })\end{array}$ & $\begin{array}{l}\text { GAMHAV } \\
\text { (1/ATM) }\end{array}$ \\
\hline 4420 & $2.02900+03$ & $4.84950-01$ & $4.2162 \mathrm{D}-01$ & $1.51840+01$ & $1.70890+03$ & $7.57050+C 0$ & $1.00430-04$ & 8. $1913 \mathrm{D}-06$ & $9.4217 D-06$ & $1.0659 D+01$ \\
\hline 4430 & $2.0338 D+03$ & $4.8495 D-01$ & $4.2182 \mathrm{D}-01$ & $1.56200+01$ & $1.7072 D+03$ & $7.5616 \mathrm{D}+00$ & $1.00400-04$ & 8. $2441 \mathrm{D}-06$ & $9.4780 \mathrm{D}-06$ & $1.0593 \mathrm{D}+01$ \\
\hline 4440 & $2.0337 D+03$ & $4.84950-01$ & $4.22020-01$ & $1.6067 D+01$ & $1.70550+03$ & $7.55260+00$ & $1.00360-04$ & $8.29730-06$ & $9.5345 D-06$ & $1.0526 \mathrm{D}+01$ \\
\hline 4450 & $2.04350+03$ & $4.8495 \mathrm{D}-01$ & $4.2222 D-01$ & $1.6523 D+01$ & $1.70370+03$ & $7.54360+00$ & $1.00330-04$ & 8. $3508 D-06$ & $9.59150-06$ & $1.04600+01$ \\
\hline 4460 & $2.04840+03$ & $4.84950-01$ & $4.2242 D-01$ & $1.69900+01$ & $1.7020 D+03$ & $7.5346 \mathrm{D}+00$ & $1.00300-04$ & $8.4046 \mathrm{D}-06$ & $9.6487 \mathrm{D}-06$ & $1.0395 \mathrm{I}+01$ \\
\hline 4470 & $2.05320+03$ & $4.84950-01$ & $4.22620-01$ & $1.746 B D+C 1$ & $1.7002 D+03$ & $7.52560+00$ & $1.00260-04$ & $8.4588 D-06$ & $9.7064 D-06$ & $1.03390+01$ \\
\hline 4480 & $2.0581 D+C 3$ & $1.8495 \mathrm{D}-01$ & $4.2282 \mathrm{D}-01$ & $1.7956 \mathrm{D}+01$ & $1.6985 D+03$ & $7.5166 \mathrm{D}+00$ & $1.00230-04$ & $8.51330-06$ & $9.76440-06$ & $1.0265 \mathrm{D}+01$ \\
\hline 4490 & $2.06290+03$ & $4.8495 \mathrm{D}-01$ & $4.2301 \mathrm{D}-01$ & $1.8455 \mathrm{D}+01$ & $1.6968 D+03$ & $7.5076 \mathrm{D}+00$ & $1.00200-04$ & $8.5682 \mathrm{D}-06$ & $9.8227 \mathrm{D}-06$ & $1.02000+01$ \\
\hline 4500 & $2.0678 \mathrm{D}+03$ & $4.8+950-01$ & $4.23210-01$ & $1.8965 \mathrm{D}+01$ & $1.6950 \mathrm{D}+03$ & $7.49870+C 0$ & $1.0016 \mathrm{D}-04$ & $8.6235 \mathrm{D}-06$ & $9.88140-06$ & $1.0136 D+01$ \\
\hline 4510 & $2.0726 \mathrm{D}+03$ & $4.8495 D-01$ & $4.2341 \mathrm{D}-\mathrm{C} 1$ & $1.9486 \mathrm{D}+\mathrm{C1}$ & $1.6933 \mathrm{D}+03$ & $7.4897 D+00$ & $1.0013 \mathrm{D}-04$ & $8.6791 D-06$ & $9.9405 \mathrm{D}-06$ & $1.0073 D+01$ \\
\hline 4520 & $2.0775 D+03$ & $4.8495 \mathrm{D}-01$ & $4.2361 \mathrm{D}-01$ & $2.00180+01$ & $1.69160+03$ & $7.4807 D+00$ & $1.00100-04$ & $8.7351 D-06$ & $1.00000-05$ & $1.0010 D+01$ \\
\hline 4530 & $2 . c 823 D+03$ & $4.8495 \mathrm{D}-01$ & $4.2381 D-01$ & $2.05620+01$ & $1.6898 D+03$ & $7.4717 D+00$ & $1.0006 \mathrm{D}-04$ & $8.79140-06$ & $1.0060 \mathrm{D}-05$ & $9.94670+00$ \\
\hline 4540 & $2.08720+03$ & $4.8495 \mathrm{D}-01$ & $4.2400 \mathrm{D}-01$ & $2.11180+01$ & $1.6881 \mathrm{D}+03$ & $7.4627 D+00$ & $1.00030-04$ & $8.84820-06$ & $1.01200-05$ & $9.8842 \mathrm{D}+00$ \\
\hline 4550 & $2.0920 \mathrm{D}+\mathrm{C} 3$ & $4.84950-01$ & $4.2420 \mathrm{D}-01$ & $2.1686 D+01$ & $1.6863 D+03$ & $7.4537 D+30$ & $9.99950-05$ & $8.9053 D-06$ & $1.0181 \mathrm{D}-05$ & $9.82210+00$ \\
\hline 4560 & $2.09690+03$ & $4 . E 495 D-01$ & $4.2439 \mathrm{D}-01$ & $2.2266 D+01$ & $1.6846 \mathrm{D}+03$ & $7.44470+00$ & $9.9962 D-05$ & $8.9628 D-06$ & $1.0242 \mathrm{D}-05$ & $9.7604 D+C 0$ \\
\hline 4.570 & $2.1017 D+0.3$ & $4.84950-C 1$ & $4.24590-01$ & $2.2858 D+01$ & $1.6829 D+03$ & $7.43570+00$ & $9.9929 \mathrm{D}-05$ & $9.0206 \mathrm{D}-06$ & $1.03030-05$ & $9.6991 \mathrm{D}+0 \mathrm{~J}$ \\
\hline 4590 & $2.1066 D+03$ & $4 . \varepsilon 4950-01$ & $4.24790-01$ & $2.3462 \mathrm{D}+01$ & $1.6811 D+03$ & $7.4263 D+00$ & $9.9895 D-05$ & $9.0789 D-06$ & $1.0365 D-05$ & $9.6380 \mathrm{D}+00$ \\
\hline 4590 & $2.11140+03$ & $4.8495 \mathrm{D}-01$ & $4.24980-01$ & $2.40790+01$ & $1.6794 \mathrm{D}+03$ & $7.41780+00$ & $9.98620-05$ & $9.1375 \mathrm{D}-06$ & $1.0427 \mathrm{D}-05$ & $9.5774 D+00$ \\
\hline 4600 & $2.1163 D+03$ & 4. $8495 D-01$ & $4.2518 \mathrm{D}-01$ & $2.47090+01$ & $1.6777 D+03$ & $7.4088 \mathrm{D}+00$ & $9.9829 D-05$ & $9.1966 \mathrm{D}-06$ & $1.0489 \mathrm{D}-05$ & $9.51710+00$ \\
\hline 4610 & $2.12110+03$ & $4.8495 \mathrm{D}-\mathrm{C} 1$ & $4.2537 D-01$ & $2.53510+01$ & $1.67590+33$ & 7. $39980+00$ & $9.9796 \mathrm{D}-05$ & $9.25600-06$ & $1.0552 \mathrm{D}-05$ & $9.4572 D+00$ \\
\hline 4620 & $2.12600+c 3$ & $4.84950-01$ & $4.2557 D-01$ & $2.6007 D+01$ & $1.6742 \mathrm{D}+03$ & $7.3908 D+00$ & $9.97620-05$ & $9.3159 \mathrm{D}-06$ & $1.0616 \mathrm{D}-05$ & $9.3976 D+00$ \\
\hline 4630 & $2.13000+03$ & $4.84950-01$ & $4.2576 D-C 1$ & $2.66770+01$ & $1.6725 D+03$ & $7.3818 D+00$ & $9.9729 D-05$ & $9.37610-06$ & $1.0680 \mathrm{D}-05$ & $9.3384 D+C)$ \\
\hline $46+0$ & $2.1357 D+03$ & $4.84950-01$ & $4.2595 \cdots-01$ & $2.7359 D+01$ & $1.6707 D+03$ & $7.37280+00$ & $9.96960-05$ & $9.4368 D-06$ & $1.0744 D-05$ & $9.27950+00$ \\
\hline 4550 & $2.1405 D+03$ & $4.8495 \mathrm{D}-01$ & 4. $2615 \mathrm{D}-01$ & $2.80560+01$ & $1.6690 \mathrm{D}+03$ & $7.36390+00$ & $9.96630-05$ & $9.4979 D-06$ & $1.08080-05$ & $9.22090+00$ \\
\hline 4660 & $2.145+D+03$ & $4.84950-01$ & $4.26340-01$ & $2.8766 D+01$ & $1.66720+03$ & $7.3549 \mathrm{D}+00$ & $9.96300-05$ & $9.5594 \mathrm{D}-06$ & $1.0873 D-05$ & $9.16270+00$ \\
\hline 1670 & $2.15020+03$ & $4.84950-01$ & $4.2654 \mathrm{D}-01$ & $2.94900+01$ & $1.6655 \mathrm{D}+03$ & $7.34590+00$ & $9.95970-05$ & $9.6213 \mathrm{D}-06$ & $1.0939 D-05$ & $9.1048 D+00$ \\
\hline
\end{tabular}


THERMODNAGIC PROPERTIES OF LIQUID UPANIOM DIOXIDE

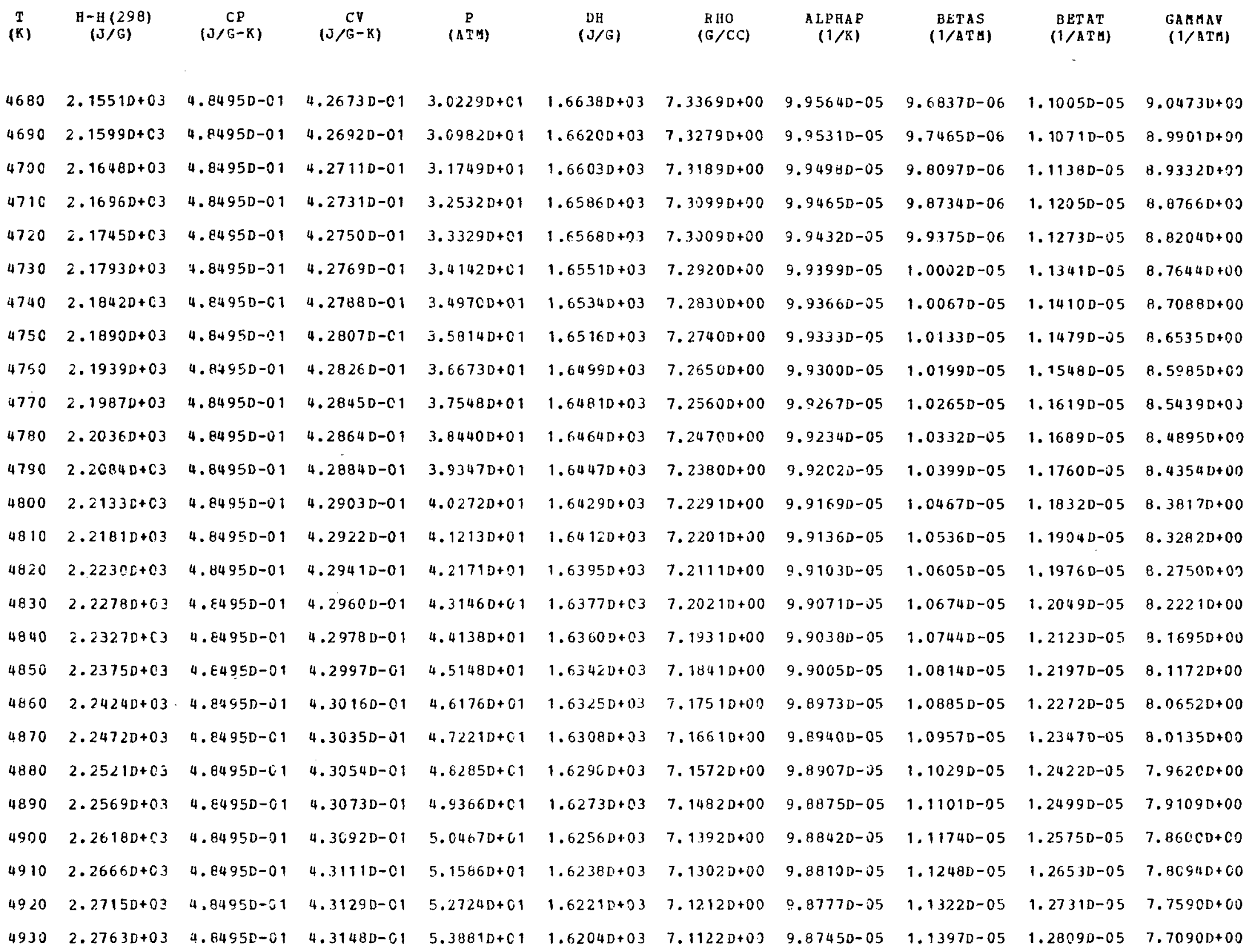


THERMODYNAMIC PROPERTIES OF LIQUID URANIUA DIOXIDE

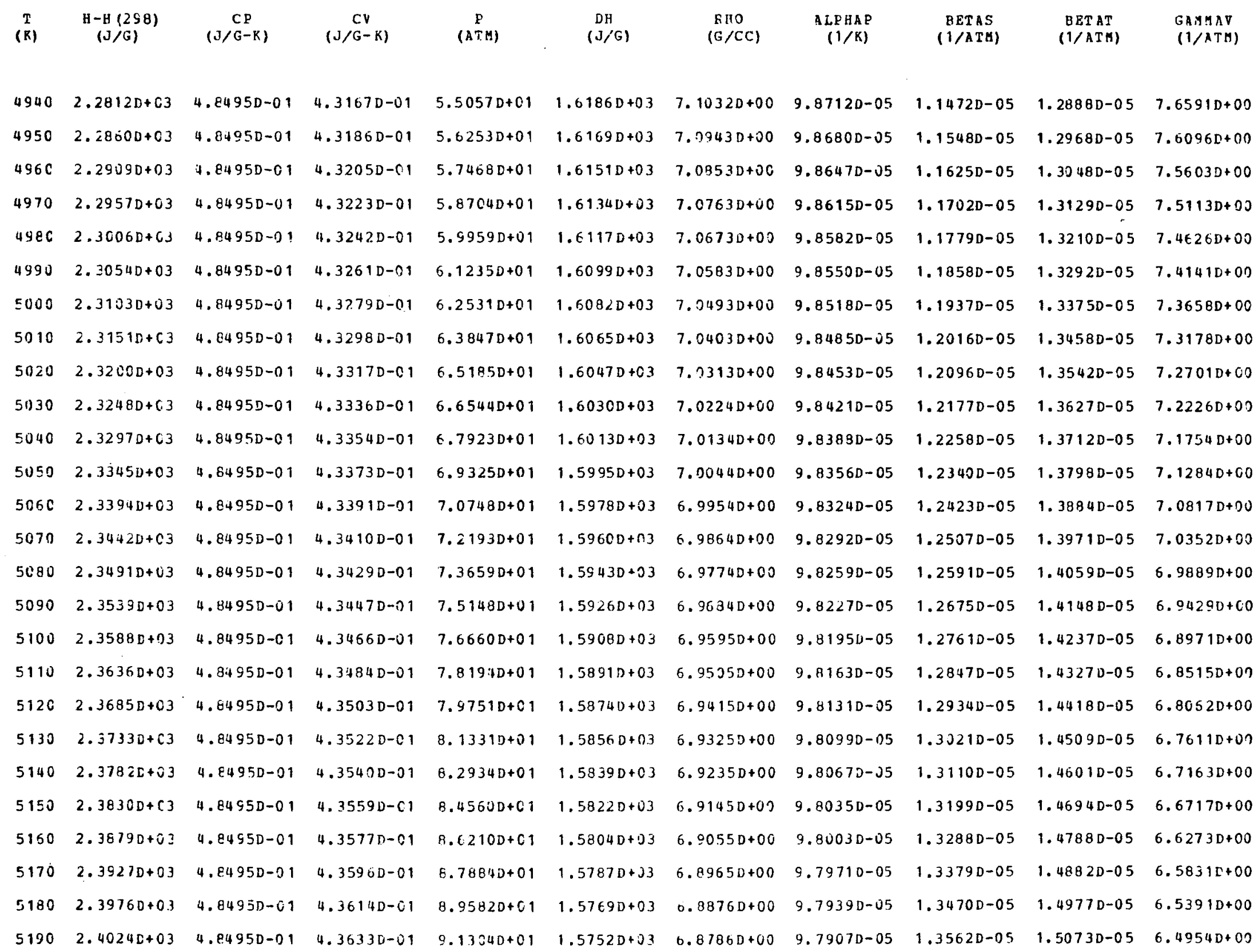


THERMODYMAMIC PBOPERTIES OF LIQUID URANIUN DIOXIDE

\begin{tabular}{|c|c|c|c|c|c|c|c|c|c|c|}
\hline $\begin{array}{c}T \\
(K)\end{array}$ & $\begin{array}{c}H-H(29 B) \\
(J / G)\end{array}$ & $\begin{array}{c}C P \\
(J / G-K)\end{array}$ & $\begin{array}{c}C V \\
(J / G-K)\end{array}$ & $\begin{array}{c}\mathbf{P} \\
(\operatorname{ATM})\end{array}$ & $\begin{array}{l}\text { DHI } \\
(J / G)\end{array}$ & $\begin{array}{l}\text { R HO } \\
(\mathrm{G} / \mathrm{CC})\end{array}$ & $\begin{array}{c}\text { ALPBAP } \\
(1 / K)\end{array}$ & $\begin{array}{c}\text { BETAS } \\
\text { (1/ATA) }\end{array}$ & $\begin{array}{l}\text { BETAT } \\
\text { (1/ATY) }\end{array}$ & $\begin{array}{l}\text { GA MAV } \\
(1 / \text { ATY) }\end{array}$ \\
\hline 200 & $.40730+03$ & $.8495 D-C 1$ & $4.3651 \mathrm{D}-01$ & $9.30500+01$ & $1.57350+03$ & $6.8696 \mathrm{D}+00$ & $9.78750-05$ & $1.3655 D-05$ & $1.51700-05$ & $6.4519 D+C 0$ \\
\hline 5210 & $2.4121 D+C 3$ & $8495 D-01$ & $36700-01$ & $9.4821 \mathrm{D}+01$ & $1.57170+03$ & $6.8006 D+00$ & $9.78430-05$ & $1.3748 D-05$ & $1.52670-05$ & $6.4086 \mathrm{D}+00$ \\
\hline 5220 & $2.4170 D+03$ & $.8495 D \rightarrow 01$ & $4.36880-01$ & $9.6616 D+01$ & $1.57000+03$ & $\epsilon .8516 D+00$ & $9.78110-05$ & $1.3843 D-05$ & $1.53660-05$ & $6.3655 \mathrm{D}+00$ \\
\hline 5230 & $2.4218 D+03$ & $4.8495 \mathrm{D}-01$ & $4.37970-01$ & $9.8437 D+01$ & $1.5683 D+03$ & $6.8426 \mathrm{D}+0 \mathrm{D}$ & $9.77790-05$ & $1.3938 D-05$ & $1.54650-05$ & $6.32260+00$ \\
\hline 240 & $2.42670+0.3$ & $4.8495 D-C 1$ & $4.3725 D-01$ & $1.0028 D+C 2$ & $1.56650+03$ & $6.83360+0 C$ & $9.7747 D-05$ & $.4034 D-05$ & $1.5565 \mathrm{D}-05$ & $6.2800 D+C D$ \\
\hline 5250 & $2.43150+03$ & 4. $8495 \mathrm{D}-01$ & $1.37440-01$ & $1 . C 215 D+02$ & $1.5648 \mathrm{D}+03$ & $6.8247 D+00$ & $9.77150-05$ & $1.4131 \mathrm{D}-05$ & $1.56660-05$ & $6.2376 \mathrm{D}+00$ \\
\hline 5200 & $2.4364 D+03$ & $.84950-01$ & $.3762 D-01$ & $1.04050+02$ & $1.5630 \mathrm{D}+03$ & $6.8157 D+00$ & $9.76840-05$ & $42290-05$ & $1.57670-05$ & $6.1953 \mathrm{D}+00$ \\
\hline 5270 & $2.4412 D+03$ & $4.8495 \mathrm{D}-01$ & $37810-01$ & $1.0597 \mathrm{D}+02$ & $1.56130+03$ & $6.8067 D+00$ & $9.7652 D-05$ & $.4327 D-05$ & $1.58700-05$ & $6.15330+00$ \\
\hline 5280 & $2.44610+03$ & $.84950-01$ & $4.3799 D-01$ & $1.07920+02$ & $1.5596 \mathrm{D}+73$ & $5.7977 D+00$ & $.7620 \mathrm{D}-05$ & $4427 D-05$ & $973 D-05$ & $6.11150+00$ \\
\hline 5290 & $2.4509 D+C 3$ & $.8495 D-01$ & $.38180-01$ & $1.09890+C 2$ & $1.5578 \mathrm{D}+03$ & $0.7387 D+00$ & $.7588 D-.25$ & $4527 D-05$ & $077 D-05$ & $6.0699 n+00$ \\
\hline 5310 & $2.46060+03$ & $.84950-01$ & $.3855 D-01$ & $1.1392 \mathrm{D}+02$ & $1.55440+03$ & $6.77070+00$ & $9.75250-05$ & $7300-05$ & $90-05$ & $5.98730+00$ \\
\hline 5320 & $2.4655 D+03$ & $4.84950-01$ & H. $3 E 73 D-C 1$ & 1. $1597 D+02$ & $1.55260+03$ & $6.7618 D+00$ & $9.74930-05$ & $48330-05$ & $6 \mathrm{D}-05$ & $5.94630+30$ \\
\hline 5330 & $2.4703 D+03$ & $.8495 D-01$ & . $3892 \mathrm{D}-01$ & 1. $1805 D+02$ & $1.5509 D+03$ & $6.7528 D+00$ & $9.74610-0.5$ & $4937 D-05$ & $534 \mathrm{D}-05$ & $9055 D+00$ \\
\hline 5340 & $2.47520+03$ & $.84950-01$ & $.3910 D-01$ & 1. $2016 \mathrm{D}+02$ & $1.5492 D+93$ & $6.74380+00$ & $9.74300-05$ & $5042 D-05$ & $612 \mathrm{D}-05$ & $5.8649 D+00$ \\
\hline 5350 & $2.48000+03$ & $.84950-01$ & $.3928 D-01$ & $2290+02$ & $1.54740+03$ & $6.73480+00$ & $9.73980-05$ & $5148 D-05$ & $1220-05$ & $3245 D+00$ \\
\hline 5360 & $2.4848 D+03$ & $4.64950-01$ & $4.39470-01$ & 1. $2445 \mathrm{D}+02$ & $1.5457 D+03$ & $6.7258 D+00$ & $9.73665-05$ & $5254 \mathrm{D}-05$ & $8330-05$ & $5.78430+00$ \\
\hline 5370 & $2.48970+03$ & $4.8495 \mathrm{D}-01$ & $4.3965 D-01$ & $1.26640+02$ & $1.5439 D+03$ & $6.71680+00$ & $9.7335 \mathrm{D}-05$ & $1.5362 D-05$ & $945 \mathrm{D}-05$ & $5.7442 D+00$ \\
\hline 5380 & $2.4945 D+03$ & $4.84950-01$ & $4.3984 D-C 1$ & $1.2896 \mathrm{D}+02$ & $1.5422 \mathrm{D}+03$ & $6.70780+00$ & $9.730 \mathrm{JD}-05$ & $5471 D-05$ & $058 D-05$ & $5.7044 D+00$ \\
\hline 5390 & $2.4994 D+C 3$ & $11.8495 \mathrm{D}-01$ & $4.4 C 02 D-C 1$ & $1.3110 D+02$ & $1.54050+03$ & $6.6988 D+00$ & $9.7272 \mathrm{D}-05$ & $5581 D-05$ & $71710-05$ & $5.6648 \mathrm{D}+00$ \\
\hline 5400 & $2.50420+03$ & $4.8495 \mathrm{D}-01$ & $4.4021 D-01$ & $1.3337 \mathrm{D}+02$ & $1.5367 \mathrm{D}+03$ & $6.68990+00$ & $9.72400-05$ & $1.5591 \mathrm{D}-05$ & $7286 \mathrm{D}-05$ & $5.6253 \mathrm{D}+00$ \\
\hline 5410 & $2.50910+03$ & $4.84950-01$ & $4.4039 \mathrm{D}-01$ & 1. $3567 \mathrm{D}+02$ & $1.53700+03$ & $6.6809 D+00$ & $9.72090-05$ & $5803 \mathrm{D}-05$ & $.7402 D-05$ & $5.58610+00$ \\
\hline 5430 & $2.5188 D+03$ & $4.84 \subseteq 5 D-01$ & $4.4076 D-01$ & $1.4036 \mathrm{D}+02$ & $1.5335 \mathrm{D}+03$ & $6.66290+00$ & $9.71460-05$ & $1.6030 D-05$ & $1.76370-05$ & $5.5081 \mathrm{D}+00$ \\
\hline & $2.52360+03$ & $4.8495 \mathrm{D}-01$ & $4.4095 \mathrm{D}-01$ & $1.42740+02$ & $1.5318 D+03$ & $6.65390+00$ & $9.71140-05$ & $1.6145 \mathrm{D}-05$ & $1.77560-05$ & $5.4694 \mathrm{D}+00$ \\
\hline & $.528 .5 D+03$ & $.84950-01$ & $.4113 D-01$ & $4516 D+02$ & $1.53010+03$ & $.6449 D+20$ & $.7083 D-05$ & $.6261 \mathrm{D}-05$ & $.7876 D-05$ & $5.4309 n+00$ \\
\hline
\end{tabular}


THERMODYNAGIC PROPERTIES OF LIQUID URANIUG DIOXIDE

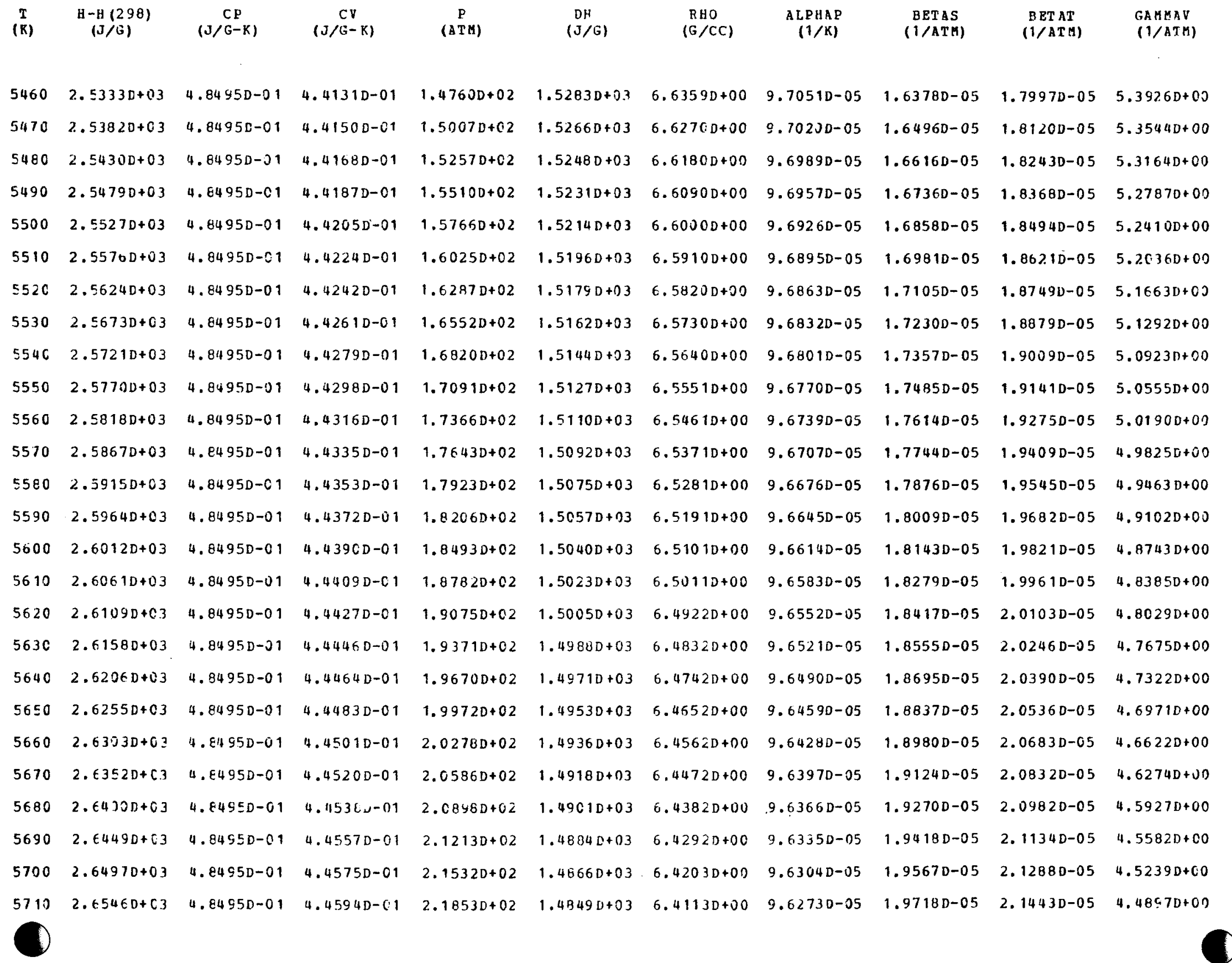


THERLOTRAMIC PROFERTIES OF LIQUID URANIUM DIOXIDE

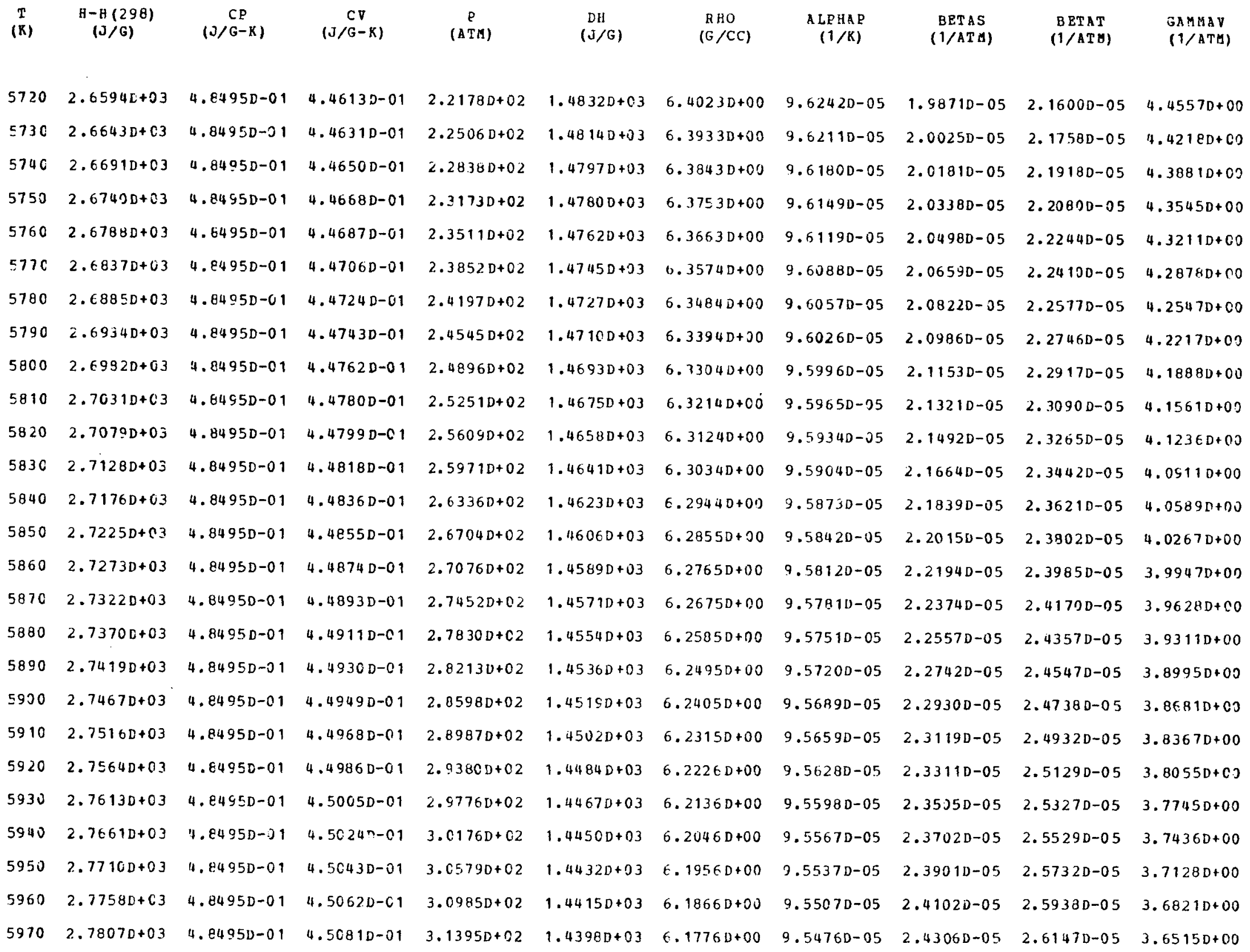


THERMCDYNAMIC PROPERTIES OF I. IQUID URANIUN DIOXIDE

\begin{tabular}{|c|c|c|c|c|c|c|c|c|c|c|}
\hline $\begin{array}{c}T \\
(K)\end{array}$ & $\begin{array}{c}H-\mathrm{H}(298) \\
(J / G)\end{array}$ & $\begin{array}{c}C P \\
(J / G-K)\end{array}$ & $\begin{array}{c}C V \\
(J / G-K)\end{array}$ & $\begin{array}{c}P \\
(\operatorname{ATM})\end{array}$ & $\begin{array}{l}\mathrm{DH} \\
(\mathrm{J} / \mathrm{G})\end{array}$ & $\begin{array}{l}\mathrm{RHO} \\
(\mathrm{G} / \mathrm{CC})\end{array}$ & $\begin{array}{c}\text { A LPHAP } \\
(1 / K)\end{array}$ & $\begin{array}{c}\text { BETAS } \\
\text { (1/ATM) }\end{array}$ & $\begin{array}{c}\text { BETAT } \\
(1 / \text { ATM })\end{array}$ & $\begin{array}{l}\text { GAMMAV } \\
(1 / A T A)\end{array}$ \\
\hline 5980 & $2.7855 D+c 3$ & $4.84950-01$ & $4.5100 D-01$ & $3.18090+02$ & $1.438 C D+03$ & $6.16860+00$ & $9.54460-05$ & $2.45130-05$ & $2.6358 D-05$ & $3.6211 \mathrm{D}+00$ \\
\hline 5990 & $2.7904 D+03$ & $4.8495 D-01$ & $4.5 \uparrow 19 D-01$ & $3.2226 \mathrm{D}+02$ & $1.4363 D+03$ & $6.15960+00$ & $9.54160-05$ & $2.47220-05$ & $2.6572 D-05$ & 3. $5908 \mathrm{D}+00$ \\
\hline$=00 \mathrm{C}$ & $2.7952 D+03$ & $4.8495 \mathrm{D}-01$ & $4.5137 \mathrm{D}-01$ & $3.2647 \mathrm{D}+02$ & $1.4345 \mathrm{D}+03$ & $6.1507 D+00$ & $9.53850-05$ & $2.49340-05$ & $2.67880-05$ & $3.5607 D+00$ \\
\hline
\end{tabular}


Internal:

P. B. Abramson

R. P. Anderson

D. R. Armstrong

R. Avery

L. Baker

E. S. Beckjord

C. H. Bowers

L. L. Briggs

R. C. Brubaker

L. Burris

F. A. Cafasso

J. E. Cahalan

M. G. Chasanov

T. C. Chawla

D. H. Cho

D. L. Condiff

D. J. Dever

C. E. Dickerman

D. R. Ferguson

C. L. Fink

J. K. Fink (25)

S. H. Fistedis

J. R. Folkrod

B. R. T. Frost

G. H. Golden

D. W. Green
E. E. Gruber

J. E. Harmon

D. R. Henley

J. R. Ho fmann

J. W. Holl and

$T$. H. Hughes

H. H. Hummel

B. G. Jones

J. M. Kennedy

A. E. Klickman

J. M. Kramer

L. Leibowitz (50)

L. G. LeSage

R. K. Lo

J. F. Marchaterre

W. W. Marr

W. E. Massey

T. A. McDonald

C. C. Meek

A. F. Melton

E. E. Morris

C. J. Mueller

R. B. Poeppel

A. B. Rothman

F. A. Rough

D. Rose
J. I. Sackett

R. Sevy

W. T. Sha

Y. W. Shin

J. J. Sienicki

B. W. Spencer

D. Stah 1

R. P. Stein

M. E. Stephenson

J. E. Sullivan

R. J. Teun is

D. H. Thompson

C. E. Till

A. Trave11i

P. Y. Wang

D. Warinner

D. P. Weber

R. W. Weeks

T. Y. Wei

H. U. Wider

G. H. Winslow

A. E. Wright

ANL Patent Dept.

ANL Contract File

ANL Libraries (2)

TIS Files (6)

\section{External:}

DOE-TIC, for distribution per UC-2 (188)

Manager, Chicago Operations and Regional office, DOE

R. M. Moser, DOE-CORO

Argonne Universities Association:

President

C. B. Alcock, U. Toronto

P. W. Gilles, U. Kansas

R. I. Newman, Fripp Island, S. C.

R. Acton, Sandia Labs., Albuquerque

M. G. Adamson, Vallecitos Nuclear Center, Pleasanton

H. Alter, Div. Reactor Research and Technology, USDOE

E. Arbt in, EG\&G Idaho, Inc.,

R. Bari, Brookhaven National Lab.

J. F. Barnes, Los Alamos Scientific Lab.

J. Belle, Bett is Atomic Power Lab.

D. A. Benson, Sandia Labs., Albuquerque

E. Bergeron, Sandia Labs., Albuquerque

A. Biancheria, Westinghouse Electric Corp., Advanced Reactors Div.

J. L. Bitner, Westinghouse Electric Corp., Advanced Reactors Div.

C. F. Bonilla, Columbia U.

J. Boudreau, Los Alamos Scientific Lab.

R. Boyd, Sandia Labs., Albuquerque 
R. Brehm, U. Arizona

C. Brennan, California Inst. Technology

C. R. Brinkman, Oak Ridge National Lab.

N. Brown, General Electric Co., Sunnyvale

R. D. Burns, Los Alamos Scientific Lab.

P. Callahan, Oak Ridge National Lab.

W. Camp, Sandia Labs., Albuquerque

G. Cano, Sandia Labs., Albuquerque

I. Catton, U. California, Los Angeles

A. Cezairliyan, National Bureau of Standards, Washington

E. C. Chang, General Electric Co., Sunnyvale

R. L. Coats, Sandia Labs., Albuquerque

M. Corradini, Sandia Labs., Albuquerque

C. M. Cox, Han ford Engineering Development Lab.

S. J. Creamer, CINDAS/Purdue U.

G. E. Culley, Hanford Engineering Development Lab.

R. A. Dahlgren, Sandia Labs., Albuquerque

G. P. De Vault, Los Alamos Scientific Lab.

D. T. Eggen, Northwestern U.

C. Erdman, U. Virginia

G. Flanagan, Oak Ridge National Lab.

M. H. Fontana, Oak Ridge National Lab.

V. M. Forsberg, Oak Ridge National Lab.

L. L. France, Westinghouse Electric Corp., Advanced Reactors Div.

F. X. Gavigan, Div. Reactor Research and Technology, USDOE

R. L. Gibby, Hanford Engineering Development Lab.

J. Gieseke, Battelle-Columbus Lab.

E. L. Gluekler, General Electric Co., Sunnyvale

J. Graham, Westinghouse Electric Corp., Advanced Reactors Div.

P. Greebler, General Electric Co., Sunnyvale

N. M. Greene, Oak Ridge National Lab.

J. Guppy, Brookhaven National Lab.

J. W. Hagan, Hanford Engineering Development Lab.

J. P. Hale, Hanford Engineering Development Lab.

J. E. Hanson, Hanford Engineering Development Lab.

T. P. Henry, Combustion Engineering, Windsor

R. F. Hilbert, General Electric Co., Sunnyvale

T. Hill, EG\&G Idaho, Inc.

W. Hinkle, Massachusetts Inst. Technology

J. J. Holmes, Hanford Engineering Development Lab.

J. Jackson, Los Alamos Scient ific Lab.

P. Jeuck, Stanford Research Inst.

J. D. Johnson, Los Alamos Scientific Lab.

R. Just, Oak Ridge National Lab.

W. Y. Kato, Brookhaven National Lab.

S. V. Kaye, Oak Ridge National Lab.

C. Kelber, Reactor Safety Research Div., USNRC

G. I. Kerley, Los Alamos Scientific Lab.

J. F. Kerrisk, Los Alamos Scientific Lab.

R. L. Knecht, Hanford Engineering Development Lab.

T. S. Kress, Oak Ridge National Lab.

B. Kursunoglu, U. Miami, Coral Gables

J. J. Laidler, Hanford Engineering Development Lab.

R. Lancet, Atomics International 
S. Langer, General Atomic Co.

D. R. Lide, National Bureau of Standards, Washington

D. E. Mahagin, Hanford Engineering Development Lab.

G. A. Mansoori, U. of Illinois, Chicago

M. F. Marchbanks, Hanford Engineering Development Lab.

R. A. Markley, Westinghouse Electric Corp., Advanced Reactors Div.

R. Mason, EG\&G Idaho, Inc.

L. M. McWethy, Hanford Engineering Development Lab.

R. A. Moen, Hanford Engineering Development Lab.

H. A. Morewitz, Atomics International

L. D. Muhlestein, Hanford Engineering Development Lab.

E. Novendstern, Westinghouse Electric Corp., Madison

$R$. Noyes, Combustion Engineering, Windsor

D. R. Olander, U. California, Berkeley

R. W. Ostensen, Sandia Labs., Albuquerque

A. Padilla, Hanford Engineering Development Lab.

W. Pasco, Clinch River Breeder Reactor Plant, Oak Ridge

R. E. Peterson, Hanford Engineering Development Lab.

M. S. Plesset, California Inst. Technology

C. E. Pugh, Oak Ridge National Lab.

A. Reed, Sandia Labs., Albuquerque

A. B. Reynolds, U. Virginia

D. P. Schively, Hanford Engineering Development Lab.

J. H. Scott, Los Alamos Scientific Lab.

W. F. Sheely, Hanford Engineering Development Lab.

M. T. Simnad, General Atomic Co.

D. E. Simpson, Hanford Engineering Development Lab.

D. Slagle, Hanford Engineering Development Lab.

G. M. Slaughter, Oak Ridge National Lab.

T. Speis, Nuclear Regulatory Research, USNRC

D. D. Stepnewski, Hanford Engineering Development Lab.

M. G. Stevenson, Los Alamos Scientific Lab.

L. Strawbridge, Westinghouse Electric Corp., Advanced Reactors Div.

D. Switick, General Electric Co., Sunnyvale

M. I. Temme, General Electric Co., Sunnyvale

L. Thompson, Reactor Safety Research Div., USNRC

R. Tilbrook, Westinghouse Electric Corp., Advanced Reactors Div.

D. Tobin, Stanford Research Inst.

N. E. Todreas, Massachusetts Inst. Technology

A. Torri, General Atomic Co.

P. Tschamper, General Electric Co., Sunnyvale

R. M. Vijuk, Westinghouse Electric Corp., Advanced Reactors Div.

A. E. Waltar, Hanford Engineering Development Lab.

E. T. Weber, Hanford Engineering Development Lab.

G. L. Wire, Hanford Engineering Development Lab.

J. Wright, Los Alamos Scientific Lab.

B. Wrona, Babcock \& Wilcox Co., Lynchburg 